SYSTEMATICS OF THE SHORT-TAILED WHIPSCORPION GENUS STENOCHRUS CHAMBERLIN, 1922

(SCHIZOMIDA: HUBBARDIIDAE), WITH DESCRIPTIONS OF SIX NEW GENERA AND FIVE NEW SPECIES

\author{
RODRIGO MONJARAZ-RUEDAS, \\ LORENZO PRENDINI, \\ AND OSCAR F. FRANCKE
}

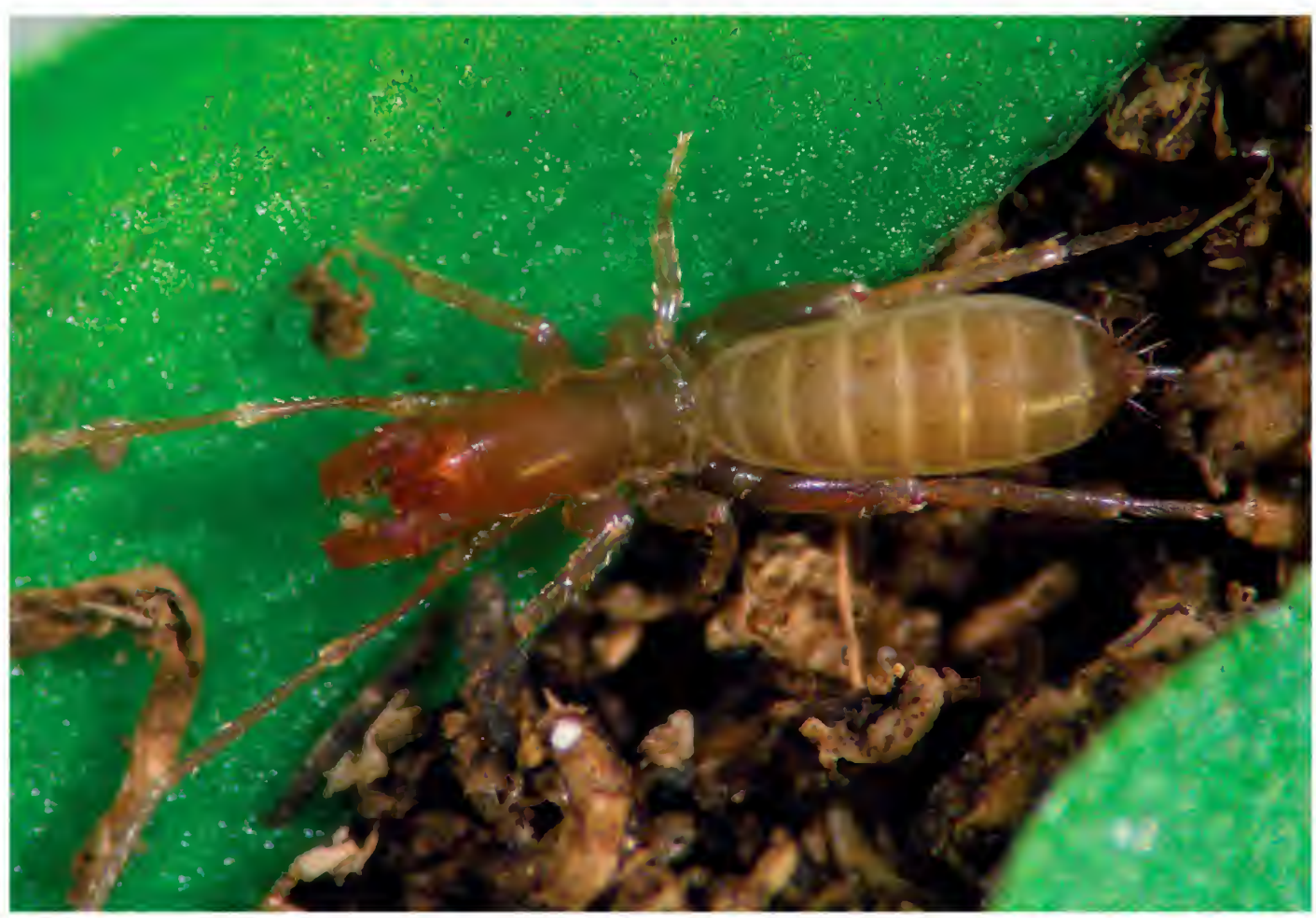

BULLETIN OF THE AMERICAN MUSEUM OF NATURAL HISTORY 


\title{
SYSTEMATICS OF THE SHORT-TAILED WHIPSCORPION GENUS STENOCHRUS CHAMBERLIN, 1922 (SCHIZOMIDA: HUBBARDIIDAE), WITH DESCRIPTIONS OF SIX NEW GENERA AND FIVE NEW SPECIES
}

\author{
RODRIGO MONJARAZ-RUEDAS \\ Posgrado en Ciencias Biológicas, \\ Universidad Nacional Autónoma de México; \\ Colección Nacional de Arácnidos, \\ Departamento de Zoología, Instituto de Biología, \\ Universidad Nacional Autónoma de México
}

LORENZO PRENDINI

Division of Invertebrate Zoology, American Museum of Natural History

OSCAR F. FRANCKE

Colección Nacional de Arácnidos, Departamento de Zoología, Instituto de Biología, Universidad Nacional Autónoma de México 



\section{CONTENTS}

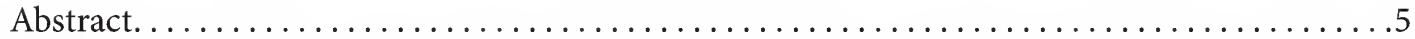

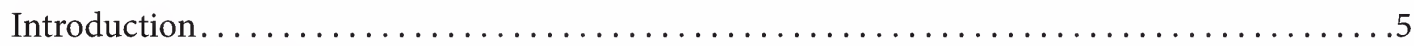

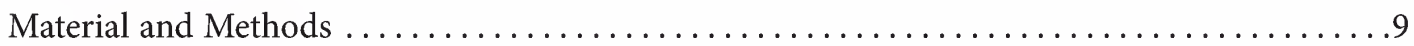

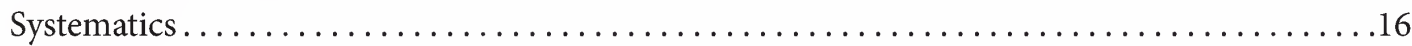

Key to Identification of the North American Genera of Hubbardiidae (Schizomida) ....16

Family Hubbardiidae Cook, 1899 .................................... 18

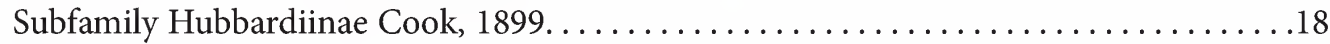

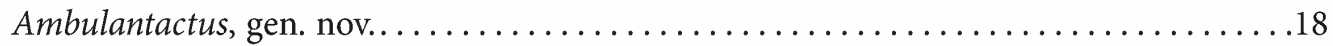

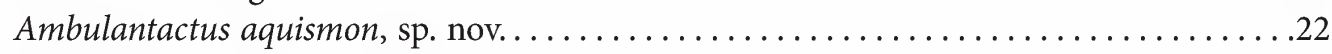

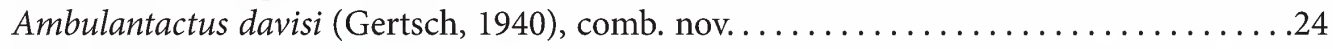

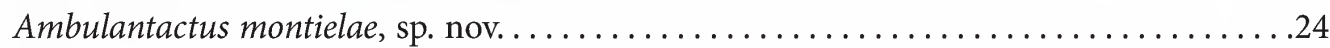

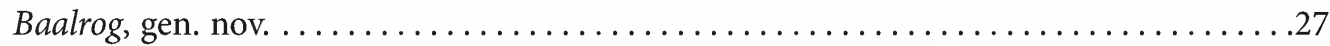

Baalrog firstmani (Rowland, 1973), comb. nov........................ 32

Baalrog magico (Monjaraz-Ruedas and Francke, 2018), comb. nov. . . . . . . . . . . . 33

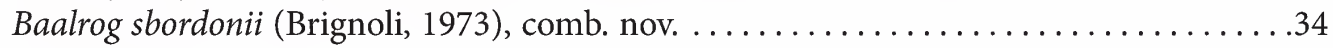

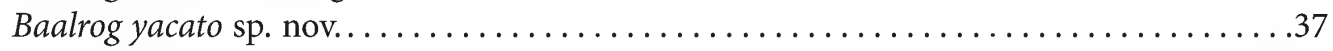

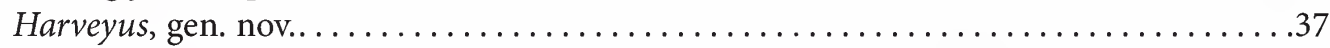

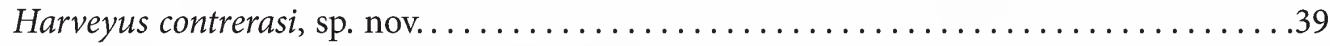

Harveyus mexicanus (Rowland, 1971), comb. nov. ......................... 40

Harveyus mulaiki (Gertsch, 1940), comb. nov. .......................... 41

Harveyus reddelli (Rowland, 1971), comb. nov............................. . . . .

Heteroschizomus Rowland, 1973, stat. rev. ............................... 44

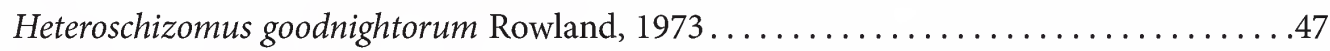

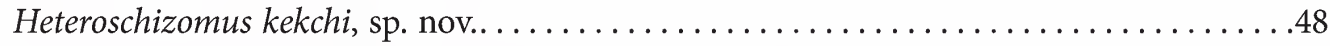

Heteroschizomus orthoplax (Rowland, 1973), comb. nov. ...................49

Heteroschizomus silvino (Rowland and Reddell, 1977), comb. nov. ...............51

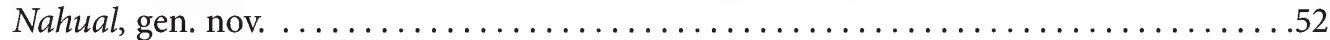

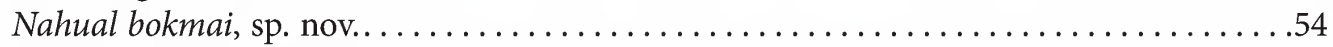

Nahual caballero (Monjaraz-Ruedas and Francke, 2018), comb. nov. ..............56

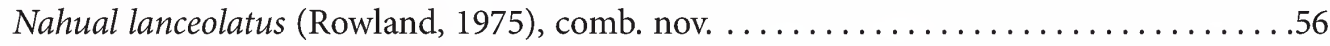

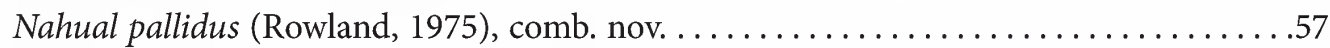

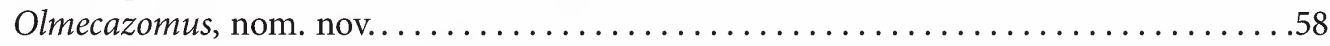

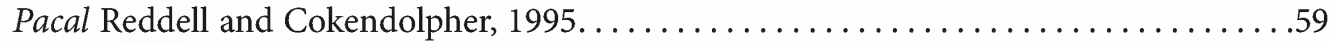

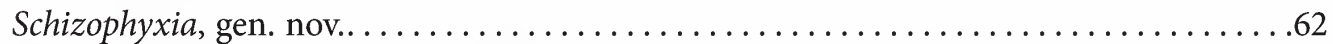

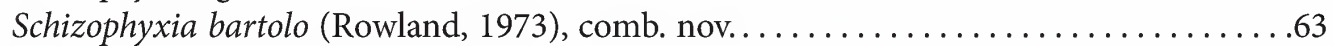

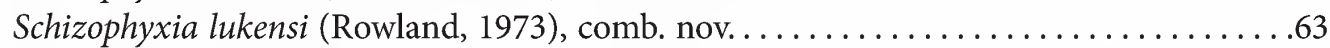

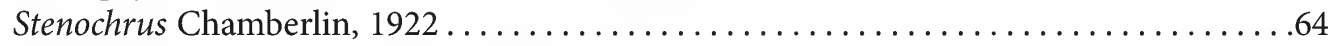

Stenochrus alcalai Monjaraz-Ruedas and Francke, 2018 ...................68

Stenochrus chimalapas Monjaraz-Ruedas and Francke, 2018 . . . . . . . . . . . . 68

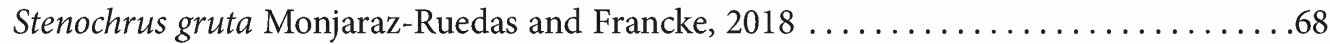

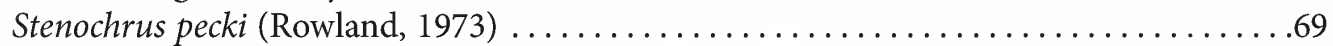

Stenochrus portoricensis Chamberlin, 1922 ........................69 


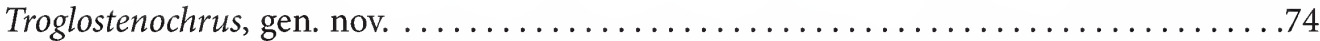

Troglostenochrus palaciosi (Reddell and Cokendolpher, 1986), comb. nov. ...........75

Troglostenochrus valdezi (Monjaraz-Ruedas, 2012), comb. nov. ................... 75

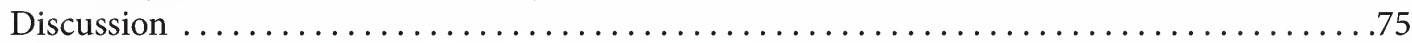

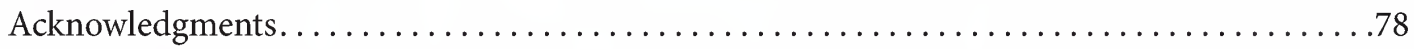

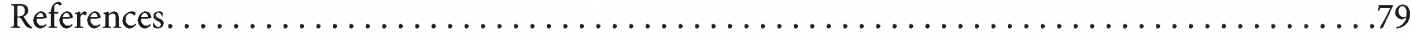

Appendix 1. Morphological characters used in phylogenetic analysis of the short-tailed whipscorpion genus Stenochrus Chamberlin, 1922, and related genera (Schizomida: Hubbardiidae) ...... 88 Appendix 2. Voucher numbers for tissue samples and GenBank accession codes for

DNA sequences ............................................... 90 


\begin{abstract}
The short-tailed whipscorpion genus, Stenochrus Chamberlin, 1922 (Schizomida: Hubbardiidae Cook, 1899), occurring in North and Central America, is redefined and revised based on simultaneous phylogenetic analysis of 61 morphological characters and 2968 aligned DNA nucleotides from two markers in the nuclear genome, the internal transcribed spacer (ITS) and 28S rDNA, and two markers in the mitochondrial genome, cytochome $c$ oxidase subunit I (COI) and $12 \mathrm{~S}$ rDNA, for a comprehensive taxon sample. Six new genera are described: Ambulantactus, gen. nov.; Baalrog, gen. nov.; Harveyus, gen. nov.; Nahual, gen. nov.; Schizophyxia, gen. nov.; Troglostenochrus, gen. nov. Heteroschizomus Rowland, 1973, stat. rev., is revalidated and its type species, Heteroschizomus goodnightorum Rowland, 1973, reinstated. Six new species are described: Ambulantactus aquismon, sp. nov.; Ambulantactus montielae, sp. nov.; Baalrog yacato, sp. nov.; Harveyus contrerasi, sp. nov.; Heteroschizomus kekchi, sp. nov.; Nahual bokmai, sp. nov. Eighteen new combinations are created by transferring species, previously accommodated in Stenochrus, to other genera: Ambulantactus davisi (Gertsch, 1940), comb. nov.; Baalrog magico (Monjaraz-Ruedas and Francke, 2018), comb. nov.; Baalrog sbordonii (Brignoli, 1973), comb. nov.; Harveyus mexicanus (Rowland, 1971a), comb. nov.; Harveyus mulaiki (Gertsch, 1940), comb. nov.; Harveyus reddelli (Rowland, 1971a), comb. nov.; Heteroschizomus meambar (Armas and Víquez, 2010), comb. nov.; Heteroschizomus orthoplax (Rowland, 1973a), comb. nov.; Heteroschizomus silvino (Rowland and Reddell, 1977), comb. nov.; Nahual caballero (Monjaraz-Ruedas and Francke, 2018), comb. nov.; Nahual lanceolatus (Rowland, 1975), comb. nov.; Nahual pallidus (Rowland, 1975), comb. nov.; Pacal moisii (Rowland, 1973), comb. nov.; Pacal tepezcuintle (Armas and Cruz-López, 2009), comb. nov.; Schizophyxia bartolo (Rowland, 1973), comb. nov.; Schizophyxia lukensi (Rowland, 1973), comb. nov.; Troglostenochrus palaciosi (Reddell and Cokendolpher, 1986), comb. nov.; Troglostenochrus valdezi (Monjaraz-Ruedas, 2012), comb. nov. The male of B. sbordonii is determined to be heterospecific with the holotype female and described as B. yacato. The females of $H$. goodnightorum and $N$. lanceolatus are described for the first time. Following these revisions, seven species remain within Stenochrus: Stenochrus alcalai Monjaraz-Ruedas and Francke, 2018; Stenochrus chimalapas Monjaraz-Ruedas and Francke, 2018; Stenochrus gruta Monjaraz-Ruedas and Francke, 2018; Stenochrus guatemalensis (Chamberlin, 1922); Stenochrus leon Armas, 1995; Stenochrus pecki (Rowland, 1973); Stenochrus portoricensis Chamberlin, 1922. Olmecazomus, nom. nov., is proposed as a replacement name for the junior homonym, Olmeca Monjaraz-Ruedas and Francke, 2017, creating three new combinations: Olmecazomus brujo (Monjaraz-Ruedas and Francke, 2017), comb. nov.; Olmecazomus cruzlopezi (Monjaraz-Ruedas and Francke, 2017), comb. nov.; Olmecazomus santibanezi (Monjaraz-Ruedas and Francke, 2017), comb. nov. A key to identification of the hubbardiid genera of North America is provided and the utility of various character systems for the diagnosis of schizomid genera discussed. The integration of morphological and molecular data not only increased knowledge of the schizomid diversity in the New World but disentangled what was once considered a homoplastic and variable morphology in a large "catch-all" genus into discrete units each diagnosable by unique character combinations.
\end{abstract}

\section{INTRODUCTION}

The order Schizomida Petrunkevitch, 1945, commonly known as the short-tailed whipscorpions, schizomids, or tartarids, is among the less diverse, or minor, arachnid orders (Harvey, 2003). It currently comprises only two families, Protoschizomidae Rowland, 1975, endemic to North America, with two extant and one fossil genera and 16 species, and Hubbardiidae Cook,
1899, with 59 extant genera and 339 species worldwide (Harvey, 2003, 2013; Monjaraz-Ruedas and Francke, 2015). Within the New World, Hubbardiidae contains 27 genera, including Stenochrus Chamberlin, 1922, the most speciose schizomid genus in North America and the third most speciose in the New World (Reddell and Cokendolpher, 1995; Harvey, 2013).

When first described, Stenochrus was monotypic, including only the type species, Stenochrus 
portoricensis Chamberlin, 1922. Chamberlin (1922) erroneously diagnosed the genus by the absence of mesopeltidia, justifying its later synonymy with Schizomus Cook, 1899, by Rowland (1973a) who also created Heteroschizomus Rowland, 1973, to accommodate a rare new species from the Yucatán with a peculiarly enlarged opisthosoma and a lanceolate male pygidial flagellum. Rowland (1973a) mistakenly associated a heterospecific female with the holotype male of the type species of Heteroschizomus, leading to the erroneous conclusion that the female spermathecae of Heteroschizomus resembled those of Schizomus. Heteroschizomus was subsequently synonymized with Schizomus by Rowland and Reddell (1977), based in part on the discovery of other species with an enlarged opisthosoma.

Stenochrus remained in synonymy with Schizomus until it was revalidated, and Heteroschizomus newly synonymized with it by Reddell and Cokendolpher (1991), based in part on decisions originating from Rowland (1975b). Rowland (1975b) presented the first phylogeny of schizomids, an analysis of 12 morphological characters for the six groups of New World species in the genus Schizomus, which was never published. Based on the analysis, Rowland (1975b) proposed seven species groups of Schizomus, i.e., the brasiliensis, briggsi, dumitrescoae, goodnightorum, mexicanus, pecki, and simonis groups. The briggsi group was placed sister to a monophyletic group comprising two reciprocally monophyletic subgroups, one comprising the brasiliensis, dumitrescoae, and simonis groups, the other comprising the goodnightorum, mexicanus, and pecki groups in Rowland's (1975b) unpublished phylogeny. The seven species groups were formally diagnosed and published by Rowland and Reddell (1979a, 1979b, 1980, 1981). Rowland and Reddell $(1980,1981)$ placed 16 species of Schizomus from the United States, Mexico, and Guatemala into the goodnightorum, mexicanus, and pecki groups. However, further studies by Reddell and Cokendolpher (1991, 1995) demonstrated that Schizomus and another schizomid genus, Trithyreus Kraepelin, 1899, do not occur in the New World, leading Reddell and Cokendol- pher (1991) to revalidate Stenochrus and synonymize Heteroschizomus with it. The genus Sotanostenochrus Reddell and Cokendolpher, 1991, was created for two species in the mexicanus group. According to Reddell and Cokendolpher (1991) all species of Stenochrus shared the absence of pedipalp armature and a posterodorsal process on opisthosomal segment XII, the male pygidial flagellum sloping sharply posteriorly, the female pygidial flagellum comprising three flagellomeres, and the female spermathecae with two pairs of lobes, the lateral pair reduced in size; and all except Stenochrus mexicanus Rowland, 1971, shared the presence of homeomorphic pedipalps. Supposedly, the "discovery" of the female of Stenochrus goodnightorum Rowland, 1973, with reduced lateral lobes of the spermathecae, reinforced the synonymy of Heteroschizomus within Stenochrus (Rowland and Reddell, 1980).

Having established that Schizomus is not a New World genus, Reddell and Cokendolpher (1995) assigned Rowland's (1975b) species groups to other existing genera and created new genera to accommodate the rest. Species of the simonis group were transferred to Hansenochrus Reddell and Cokendolpher, 1995, the briggsi group to Hubbardia Cook, 1899, and the goodnightorum, mexicanus, and pecki groups to Stenochrus. Pacal Reddell and Cokendolpher, 1995, and Surazomus Reddell and Cokendolpher, 1995, were created to accommodate species of the brasiliensis group, and Rowlandius Reddell and Cokendolpher, 1995, to accommodate the dumitrescoae group. Reddell and Cokendolpher (1995) transferred Schizomus alejandroi Armas, 1989, described from Holguín, Cuba, to Stenochrus, creating the new combination, Stenochrus alejandroi (Armas, 1989a).

Armas and Teruel (1998) created the brevipatellatus group of Stenochrus, to accommodate Stenochrus alejandroi, Stenochrus brevipatellatus (Rowland and Reddell, 1979), Stenochrus cerdoso (Camilo and Cokendolpher, 1988), and Stenochrus subcerdoso (Armas and Abud-Antun, 1990), all of which share a reduced pedipalp patella and the presence of four and six setae on opisthosomal segment II. Armas and Teruel (2002) created Antillo- 
stenochrus Armas and Teruel, 2002, to accommodate the species of the brevipatellatus group, where they have remained since.

Another seven species of Stenochrus were subsequently described from Mexico and one from Honduras (Armas and Cruz-López, 2009; Armas and Víquez, 2010; Monjaraz-Ruedas, 2012; Monjaraz-Ruedas and Francke, 2018). A fossil species, Stenochrus velteni Krüger and Dunlop, 2010, was described from the Dominican Republic but subsequently tranferred to Rowlandius by Armas and Teruel (2011), based on the shape of the male pygidial flagellum and the apparent diversity of that genus on Hispaniola.

When the present study commenced, Stenochrus contained 27 species, distributed mostly in the Nearctic region, from the southern United States, through Mexico to Central America (table 1, figs. 1-5). One cosmopolitan species, Stenochrus portoricensis Chamberlin, 1922, was reported from North, Central, and South America and the Caribbean, as well as several countries in Europe (Korenko et al., 2009; Christophoryová et al., 2013; Harvey, 2013). The morphological disparity among species of Stenochrus, reflected by variation in body size, male flagellar shape, setal patterns and sexual dimorphism, including homeomorphic and heteromorphic pedipalps, and their diverse habitats, including caves, rainforest, tropical dry forest, and pine and oak forest above $2000 \mathrm{~m}$, raised the question as to whether the genus is monophyletic. Given the paucity of phylogenetic analyses on schizomids, it is unsurprising that the monophyly and phylogenetic relationships of Stenochrus have never been tested, beyond the unpublished analysis of Rowland (1975b), which was based on 12 morphological characters, and the inclusion of several exemplar species of Stenochrus in recent analyses of schizomid phylogeny based on morphology (Monjaraz-Ruedas and Francke, 2016, 2017) and DNA sequences (Clouse et al., 2017). In an analysis of Mayazomus Reddell and Cokendolpher, 1995, phylogeny by Monjaraz-Ruedas and Francke (2016), based on 130 morphological characters, which included exemplar species of Stenochrus as outgroups, along with outgroup exemplars of Han- senochrus, Hubbardia, and Rowlandius from North, Central, and South America, that were members of the original species groups of Rowland and Reddell (1979a, 1979b, 1980, 1981), Stenochrus was paraphyletic. The genus was also paraphyletic in the molecular phylogenetic analysis of Clouse et al. (2017), based on two nuclear and two mitochondrial gene markers for 240 samples, which included several samples of Stenochrus portoricensis, one sample of Stenochrus sbordonii Brignoli, 1973, and several unidentified specimens from Mexico; Hubbardia grouped as sister to all other Hubbardiidae samples $(n=238)$ and $S$. sbordonii sister to the remaining taxa $(n=237)$. On the other hand, Stenochrus was monophyletic in an analysis of Olmeca Monjaraz-Ruedas and Francke, 2017, phylogeny, using different exemplar species of Stenochrus, i.e., Stenochrus pecki Rowland, 1973, and S. portoricensis, from the Mayazomus analysis (Monjaraz-Ruedas and Francke, 2017).

In the present contribution, the genus Stenochrus is redefined and revised based on simultaneous phylogenetic analysis of 61 morphological characters and 2968 aligned DNA nucleotides from two markers in the nuclear genome, the internal transcribed spacer (ITS) and $28 \mathrm{~S} \mathrm{rDNA}$, and two markers in the mitochondrial genome, cytochome $c$ oxidase subunit I (COI) and $12 \mathrm{~S}$ rDNA, for a comprehensive taxon sample (fig. 6; MonjarazRuedas et al., in prep.). Six new genera and six new species are described. Heteroschizomus is revalidated and its type species reinstated. Eighteen new combinations are created by transferring species, previously accommodated in Stenochrus, to other genera. The male of Baalrog sbordonii (Brignoli, 1973), comb. nov., is determined to be heterospecific with the holotype female and described as a new species. The females of Heteroschizomus goodnightorum Rowland, 1973, and Nahual lanceolatus (Rowland, 1975), comb. nov., are described for the first time. Following these revisions, seven species remain within Stenochrus. Olmecazomus, nom. nov., is proposed as a replacement name for the junior homonym, Olmeca, creating three new combinations. Another two new combinations are created by the transfer of two species to Pacal. A key 


\section{TABLE 1}

Diversity and distribution of North American short-tailed whipscorpion taxa associated with Stenochrus Chamberlin, 1922 (Schizomida: Hubbardiidae Cook, 1899)

\begin{tabular}{|c|c|}
\hline Taxon & Distribution \\
\hline \multicolumn{2}{|l|}{ Ambulantactus, gen. nov. } \\
\hline A. aquismon, sp. nov. & Mexico: San Luis Potosí: Aquismon \\
\hline A. davisi (Gertsch, 1940), comb. nov. & Mexico: Tamaulipas: San Fernando \\
\hline A. montielae, sp. nov. & Mexico: Morelos: Quilamula \\
\hline \multicolumn{2}{|l|}{ Baalrog, gen. nov. } \\
\hline B. firstmani (Rowland, 1973), comb. nov. & Mexico: Veracruz: Atoyac \\
\hline B. magico (Monjaraz-Ruedas and Francke, 2018), comb. nov. & Mexico: Oaxaca: Huautla \\
\hline B. sbordonii (Brignoli, 1973), comb. nov. & Mexico: Veracruz: Amatlán de los Reyes \\
\hline B. yacato, sp. nov. & Mexico: Veracruz: Atoyac \\
\hline \multicolumn{2}{|l|}{ Harveyus, gen. nov. } \\
\hline H. contrerasi, sp. nov. & Mexico: San Luis Potosí: Xilitla \\
\hline H. mexicanus (Rowland, 1971), comb. nov. & Mexico: San Luis Potosí: Ciudad Valles \\
\hline H. mulaiki (Gertsch, 1940), comb. nov. & U.S.A.: Texas: Starr County: Rio Grande City \\
\hline H. reddelli (Rowland, 1971), comb. nov. & Mexico: Tamaulipas: Ocampo \\
\hline \multicolumn{2}{|l|}{ Heteroschizomus Rowland, 1973, stat. rev. } \\
\hline H. goodnightorum Rowland, 1973 & Mexico: Yucatan: Chichen-Itza \\
\hline H. kekchi, sp. nov. & Guatemala: Izabal: Livingston \\
\hline H. meambar (Armas and Víquez, 2010), comb. nov. & Honduras: Comayagua: La Guama \\
\hline H. orthoplax (Rowland, 1973), comb. nov. & Mexico: Chiapas: Tapachula \\
\hline H. silvino (Rowland and Reddell, 1977), comb. nov. & Guatemala: Izabal: Puerto Barrios \\
\hline \multicolumn{2}{|l|}{ Nahual, gen. nov. } \\
\hline N. bokmai, sp. nov. & Mexico: Veracruz: Xalapa \\
\hline N. caballero (Monjaraz-Ruedas and Francke, 2017), comb. nov. & Mexico: Oaxaca: San José Tenango \\
\hline N. lanceolatus (Rowland, 1975), comb. nov. & Mexico: Veracruz: Ciudad Mendoza \\
\hline N. pallidus (Rowland, 1975), comb. nov. & Mexico: Veracruz: Tlilapan \\
\hline \multicolumn{2}{|l|}{ Olmecazomus, nom. nov. } \\
\hline O. brujo (Monjaraz-Ruedas and Francke, 2017), comb. nov. & Mexico: Veracruz: Los Tuxtlas \\
\hline O. cruzlopezi (Monjaraz-Ruedas and Francke, 2017), comb. nov. & Mexico: Chiapas: Tuxtla Gutierrez \\
\hline O. santibanezi (Monjaraz-Ruedas and Francke, 2017), comb. nov. & Mexico: Chiapas: Ocosingo \\
\hline \multicolumn{2}{|l|}{ Pacal Reddel and Cokendolpher, 1995} \\
\hline P. lacandonus (Rowland, 1975) & Mexico: Chiapas: Palenque \\
\hline P. moisii (Rowland, 1973), comb. nov. & Mexico: Oaxaca: Valle Nacional \\
\hline P. stewarti (Rowland, 1973) & Mexico: Oaxaca: Valle Nacional \\
\hline P. tepezcuintle (Armas and Cruz López, 2009), comb. nov. & Mexico: Oaxaca: San Miguel Soyaltepec \\
\hline P. trilobatus (Rowland, 1975) & Mexico: Tabasco: Teapa \\
\hline
\end{tabular}




\begin{tabular}{ll}
\hline \hline Taxon & Distribution \\
\hline Schizophyxia, gen. nov. & \\
S. bartolo (Rowland, 1973), comb. nov. & Mexico: Nuevo Leon: Santa Catarina \\
S. lukensi (Rowland, 1973), comb. nov. & Mexico: Tamaulipas: Gomez Farias \\
Stenochrus Chamberlin, 1922 & \\
S. alcalai Monjaraz-Ruedas and Francke, 2018 & Mexico: Oaxaca: San Pedro Jocotipac \\
S. chimalapas Monjaraz-Ruedas and Francke, 2018 & Mexico: Oaxaca: Santa Maria Chimalapas \\
S. gruta Monjaraz-Ruedas and Francke, 2018 & Mexico: Oaxaca: Sola de Vega \\
S. guatemalensis (Chamberlin, 1922) & Guatemala: San Rafael? \\
S. leon Armas, 1995 & Nicaragua: León: Telica \\
S. pecki (Rowland, 1973) & Mexico: Tabasco: Teapa \\
S. portoricensis Chamberlin, 1922 & Europe, North, Central and South America \\
Troglostenochrus, gen. nov. & \\
T. palaciosi (Reddell and Cokendolpher, 1986), comb. nov. & Mexico: Guerrero: Taxco \\
T. valdezi (Monjaraz-Ruedas, 2012), comb. nov. & Mexico: Chiapas: San Fernando \\
\hline
\end{tabular}

to identification of the hubbardiid genera of North America is provided and the utility of various character systems for the diagnosis of schizomid genera discussed.

\section{MATERIALS AND METHODS}

TAXON SAMPLING: Specimens were collected by hand and/or using an aspirator and preserved in $80 \%$ ethanol for morphological study. One or two additional specimens were preserved in $96 \%$ ethanol for DNA isolation. Material examined is deposited in the American Museum of Natural History (AMNH), New York, including the Ambrose Monell Cryocollection (AMCC); the Colección Nacional de Arácnidos (CNAN) at the Instituto de Biología, Universidad Nacional Autónoma de México (IBUNAM), Mexico City; and the Texas Memorial Museum (TMM), University of Texas, Austin. Specimens were observed using a Nikon SMZ 625 stereomicroscope with an ocular micrometer calibrated at $20 \times$. Male chelicerae were dissected and prepared for scanning electron microscopy (SEM) following the protocol of Acosta et al. (2007), with a modified cleaning process which involved three cycles of washing alternately in distilled water and biological detergent, followed by 30 seconds in an E/MC 250 Ultrasonic Cleaner
(EMC Global Technologies, Quakertown, PA). Structures were mounted on stubs using adhesive copper aluminium tape, and subsequently coated with a layer of gold-palladium in a Q150R ES Sputter Coater (Quorum Technologies, Lewes, East Sussex, UK). Prepared stubs were imaged with a Hitachi SU1510 SEM (Chiyoda City, Tokyo, Japan) at the Laboratorio Nacional de Biodiversidad (LANABIO), IBUNAM. Female spermathecae were dissected in $80 \%$ ethanol and cleared in lactophenol for 10 minutes (Krantz and Walter, 2009), preserved thereafter in Hoyer's medium, and mounted on semipermanent microscope slides. Digital photomicrographs were taken under visible light with a Leica DFC490 camera adapted to a Leica Z16 APOA stereomicroscope, assembled with LAS (Leica Application Suite) v. 4.3.0, and edited with Adobe Photoshop CS6.

Morphological Nomenclature: Morphological terminology for legs and pedipalps follows Reddell and Cokendolpher (1995), cheliceral setal nomenclature follows Lawrence (1969) as modified by Villarreal et al. (2016), pedipalp setal terminology follows Monjaraz-Ruedas et al. (2017), opisthosomal setal nomenclature follows Villarreal et al. (2016), pygidial flagellar setal terminology follows Cokendolpher and Reddell (1992) as modified by Harvey (1992) and Monjaraz-Ruedas 


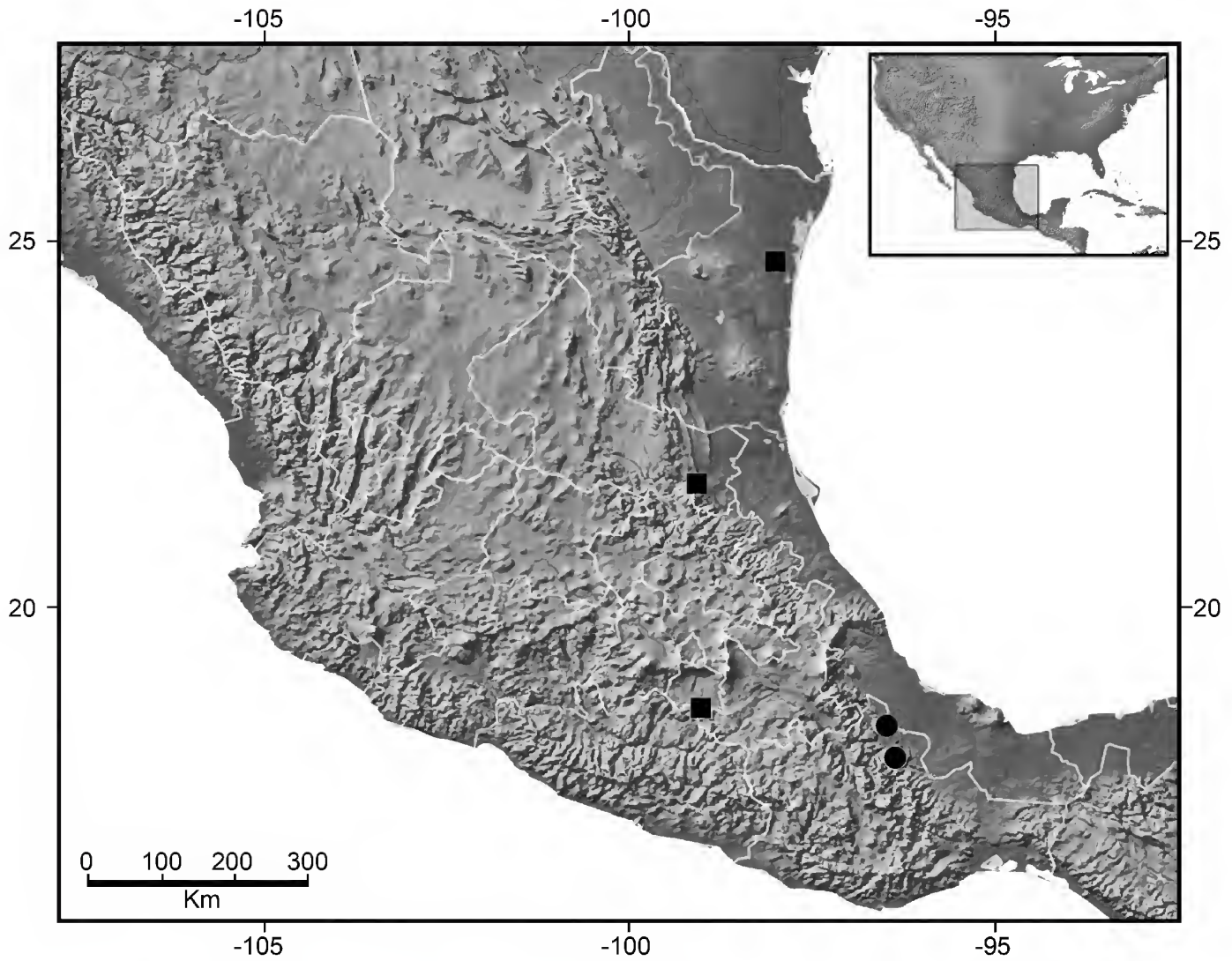

FIG. 1. Map of central Mexico, plotting known locality records for the short-tailed whipscorpion genus Ambulantactus, gen. nov. (squares), and the species recently tranferred to Pacal Reddell and Cokendolpher, 1995 (circles) (Schizomida: Hubbardiidae Cook, 1899), based on data from museum collections and the literature.

et al. (2016), and spermathecal nomenclature follows Moreno-González et al. (2014).

In order to express hypotheses of homology across morphological structures and for ease of comparison, new terminology was applied to several structures, specifically the apical process on pedipalp trochanter, the shape and ornamentation of the male pygidial flagellum, and the chitinized arch and median and lateral lobes of the female spermathecae.

Pedipalp Trochanter Apical Process: The shape of the anterior margin of the pedipalp trochanter apical process, and whether the margin projects beyond the margin of the femur, were considered. The absence of the apical process may also be interpreted as a rounded margin, i.e., not projected. The terms applied to the states of this character follow botanical terminology for leaf tips: "acute" is the most common shape observed in North American schizomids (fig. 7E, C); "acuminate" is the alternate form of the state with the margin extremely projected (fig. 7F, I); "obtuse triangle" has the margin not projected with a wide internal angle (fig. 7D); "bump" or "tubercle" is observed mainly among heteromorphic males (fig. 7H); digitiform is common in Surazomus and some species of Rowlandius.

Male Pygidial Flagellum Shape: The shape of the male pygidial flagellum in dorsal view varies depending on its size and the relief of its dorsal surface. Ten states were identified, the terms used for their description based on botanical leaf shapes: "lanceolate"; "cordate," which may also be interpreted as spade shaped; "spatulate" refers to 


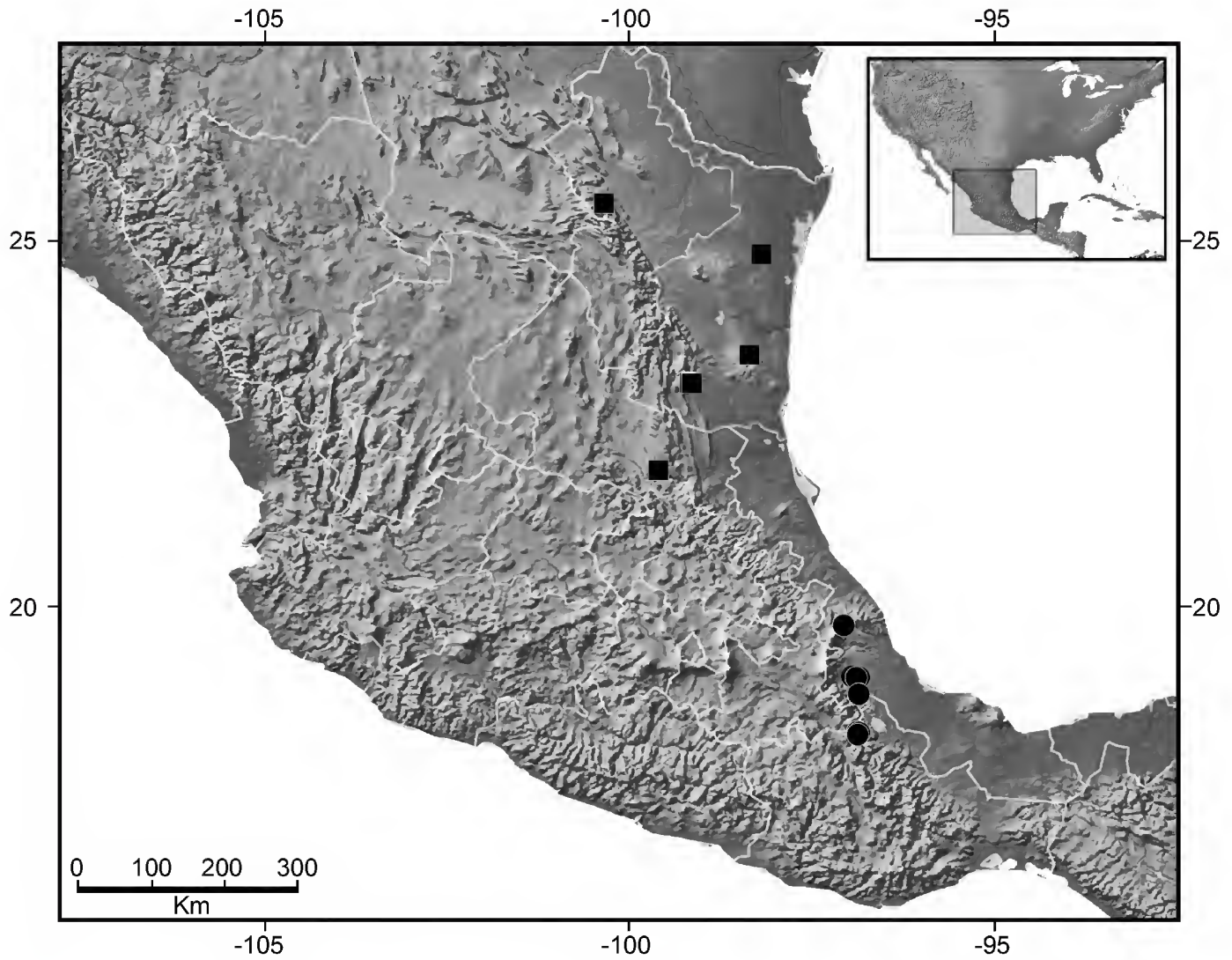

FIG. 2. Map of central Mexico, plotting known locality records for the short-tailed whipscorpion genera Baalrog, gen. nov. (circles), and Schizophyxia, gen. nov. (squares) (Schizomida: Hubbardiidae Cook, 1899), based on data from museum collections and the literature.

the flagellum observed in Heteroschizomus, stat. rev., and some species of Piaroa Villarreal et al., 2008, which comprises an anterior bulb and a posterior lobe; "subrhomboidal"; "shovel shaped"; "elliptical" may also be ovate or oval; "trilobed"; "bulbous/clavate" refers to the flagellum observed in Baalrog, gen. nov and some other species, e.g., Schizophyxia bartolo (Rowland, 1973), comb. nov., and Harveyus mulaiki (Gertsch, 1940), comb. nov., previously referred to as "club" (Rowland, 1975b); "spear shaped"; or "deltoid."

Male Pygidial Flagellum Ornamentation: Two distinct types of ornamentation were observed in the male pygidial flagellum, i.e., depressions and projections. Three states were observed among the former: circular depressions, appearing as dots or holes in the dorsal surface, previously termed "pits" by some authors (Rowland, 1975b; Rowland and Reddell, 1979b, 1980, 1981, Monjaraz-Ruedas and Francke, 2015, Moreno-González et. al., 2014); slump, a shallow depression without defined shape; and a combination of the two previous states, i.e., pits within a slump, a diagnostic character for Stenochrus. Two states were observed among projections, i.e., swellings and protuberances, which are larger, wider, and usually projected, as in Pacal and Troglostenochrus, gen. nov.

Female Spermathecae Chitinized Arch: The chitinized arch of the female spermathecae comprises several structures, i.e., the anterior branch, the posterior branch, the gonopod (atrium), and the lateral tips (Moreno-González et al., 2014). Taken together, the shapes and relative positions of these structures create a variety of unique states for the shape of the 


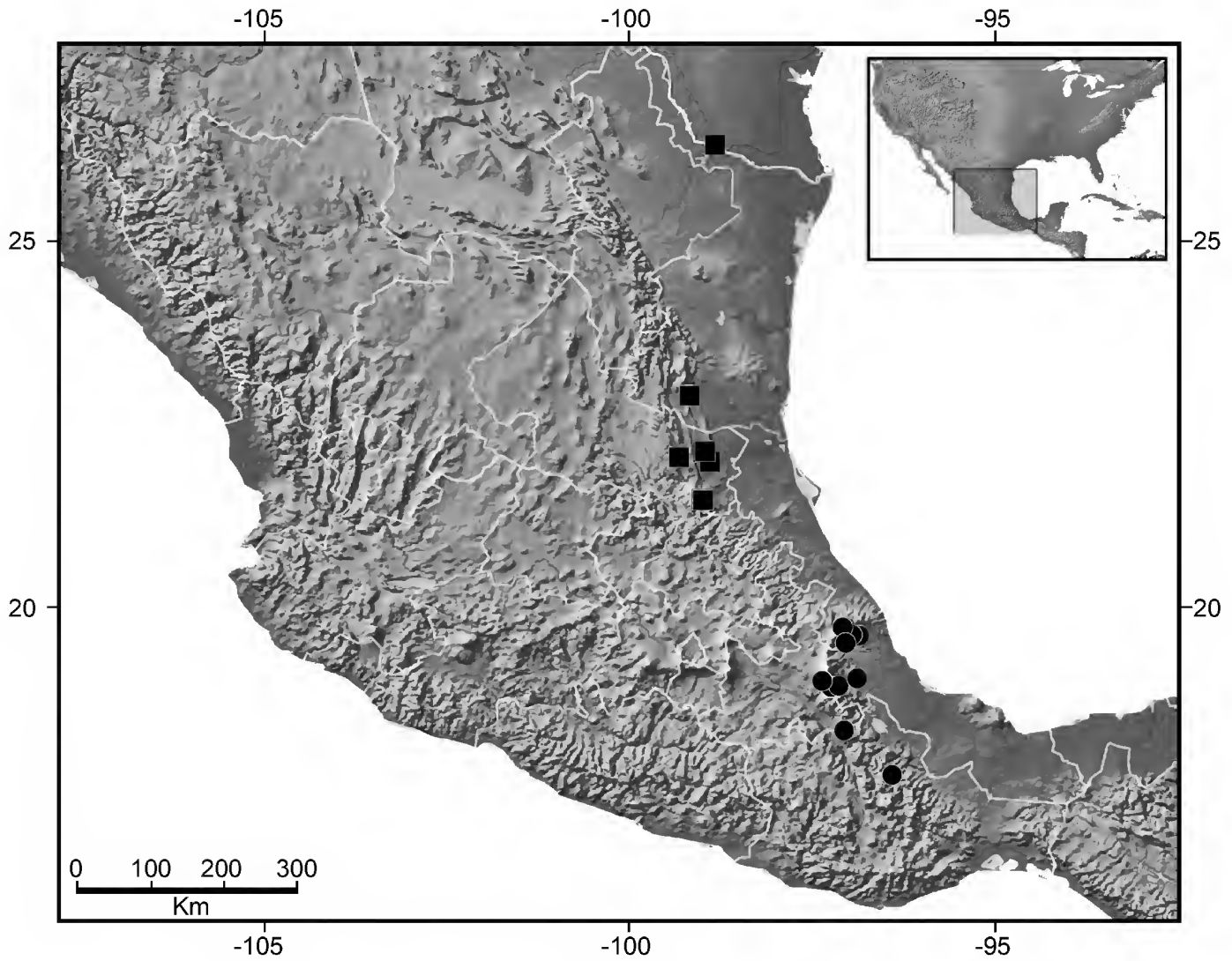

FIG. 3. Map of central Mexico, plotting known locality records for the short-tailed whipscorpion genera Harveyus, gen. nov. (squares), and Nahual, gen. nov. (circles) (Schizomida: Hubbardiidae Cook, 1899), based on data from museum collections and the literature.

chitinized arch, to which the following descriptive terms were applied: "arrow shaped" is a common condition in Nahual, gen. nov. (figs. 9A, B); "mug shaped" is common among species of Heteroschizomus (fig. 8E, F); "V-shaped" occurs in several schizomid genera, e.g., Harveyus, gen. nov., Piaroa, and Rowlandius (fig. 8D); "hastate" refers to spermathecae with long and wide lateral tips, as observed in Baalrog (fig. 8B); "bowl shaped" refers to the condition in Stenochrus, an inverse archshaped chitinized arch in which the presence of an anterior branch and a widened atrium and gonopod give the appearance of a Chinese rice bowl (fig. 9E); "inverse arch shaped" may also be interpreted as a very wide $U$-shaped chitinized arch (fig. 8A, $\mathrm{C})$; "obtuse triangle" may also be interpreted as a wide V-shaped chitinized arch (fig. 9D); and
"U-shaped," which is among the most common shapes of the chitinized arch observed in schizomids (fig. 9C).

Female Spermathecae Median and Lateral Lobes: The shape of the lobes of the female spermathecae is highly variable and may be affected by the method of fixation and slide mounting, as these lobes can move inward or outward. Despite these considerations, the general shape of the entire lobe can be reliably assessed and compared, leading to the identification of three distinct shapes: linear (I-shaped) (fig. 8A, E); inverse J-shaped (figs. 8C, 9F); curved along its length (parenthesis-shaped) (fig. 9C, E). Lobes usually bear various structures, e.g., sclerotizations, bulbs, or duct openings (figs. 8C, 9A, 9D). Sclerotizations are common among species 


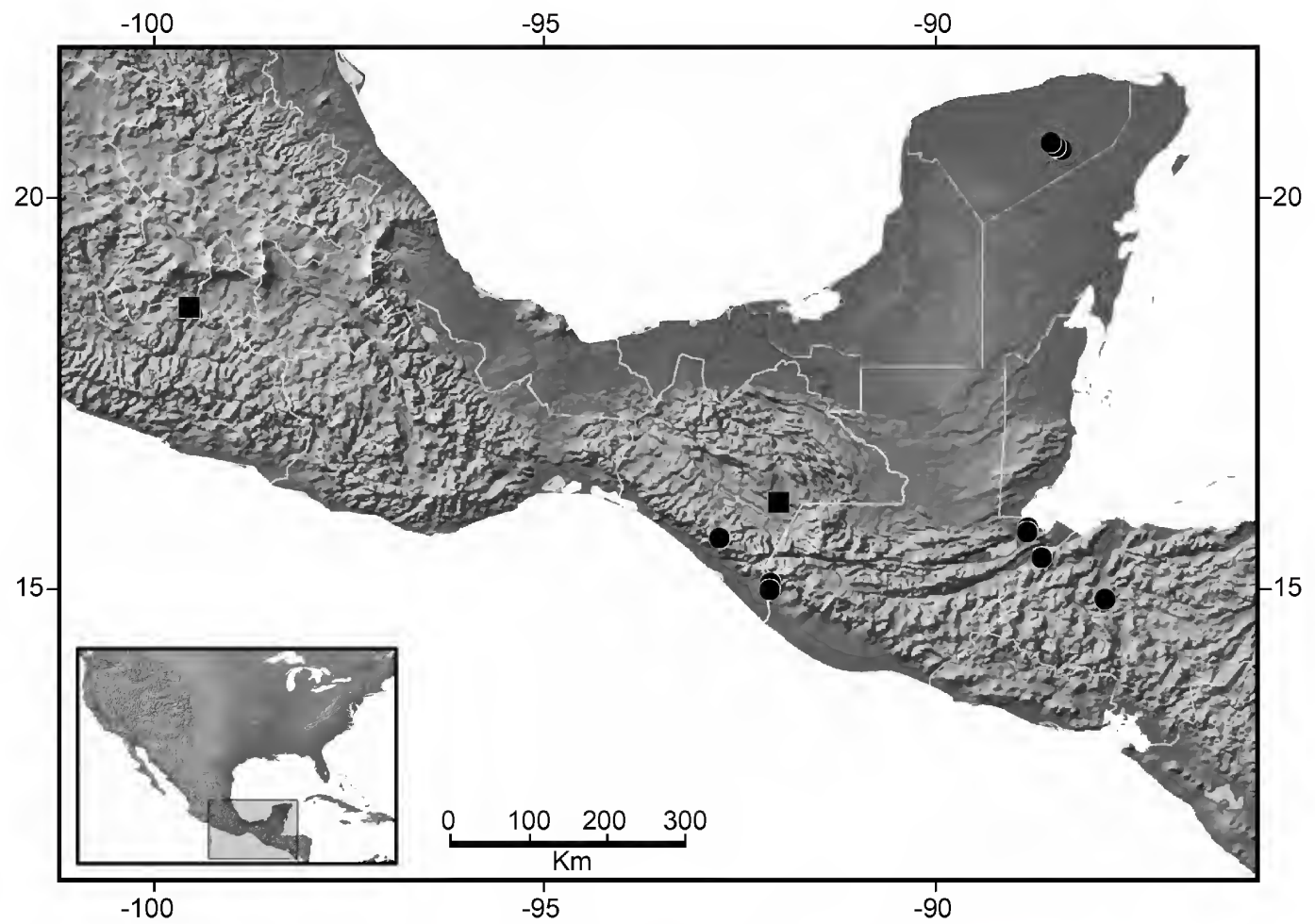

FIG. 4. Map of southern Mexico, plotting known locality records for the short-tailed whipscorpion genera Heteroschizomus Rowland, 1973, stat. rev. (circles), and Troglostenochrus, gen. nov. (squares) (Schizomida: Hubbardiidae Cook, 1899), based on data from museum collections and the literature.

of Nahual and Stenochrus (figs. 9A, B, E, 10C) whereas bulbs are observed in Harveyus, gen. nov., and Pacal (fig. 8C, D). Bulbs may vary in size: large bulbs, usually more than $4 \times$ the width of the lobe, are common in Pacal and some species of Rowlandius, whereas small bulbs, $3 \times$ or less the width of the lobes, are common among species of Harveyus and Surazomus.

Phylogenetic Analyses: A morphological data matrix, comprising 61 morphological characters (appendix 1) scored for 41 terminal taxa, was prepared using Mesquite ver. 3.0.4 (Maddison and Maddison, 2018), and deposited in Morphobank (https://morphobank.org) with accession number P3464. Forty-three multistate and 18 binary characters were modified from Monjaraz-Ruedas and Francke $(2016,2017)$ and treated as nonadditive (Fitch, 1971) to avoid a priori character state transformations.
Two markers in the nuclear genome, the internal transcribed spacer (ITS) and 28S rDNA (28S), and two markers in the mitochondrial genome, cytochome $c$ oxidase subunit I (COI) and 12S rDNA (12S), were Sanger-dideoxy sequenced using an ABI Prism 3730 XL DNA Sequencer (Perkin-Elmer, Melville, NY) at the AMNH Sackler Institute of Comparative Genomics and a 3500 XL Genetic Analyzer (Life Technologies, Foster City, CA) at the LANABIO Molecular Laboratory. Double-stranded sequences were edited and contiged into consensus sequences using Sequencher ver. 5.4.6 (Gene Codes Corporation, Ann Arbor, MI), and deposited in GenBank (https://www.ncbi.nlm.nih.gov/genbank) (appendix 2). Sequences of the $28 \mathrm{~S}$ marker were length invariant, comprising 501 base pairs (bp) in all terminals whereas sequences of the ITS marker varied from 637-837 bp with an average of $806 \mathrm{bp}$, and of the $12 \mathrm{~S}$ fragment from $319-387 \mathrm{bp}$ with an 


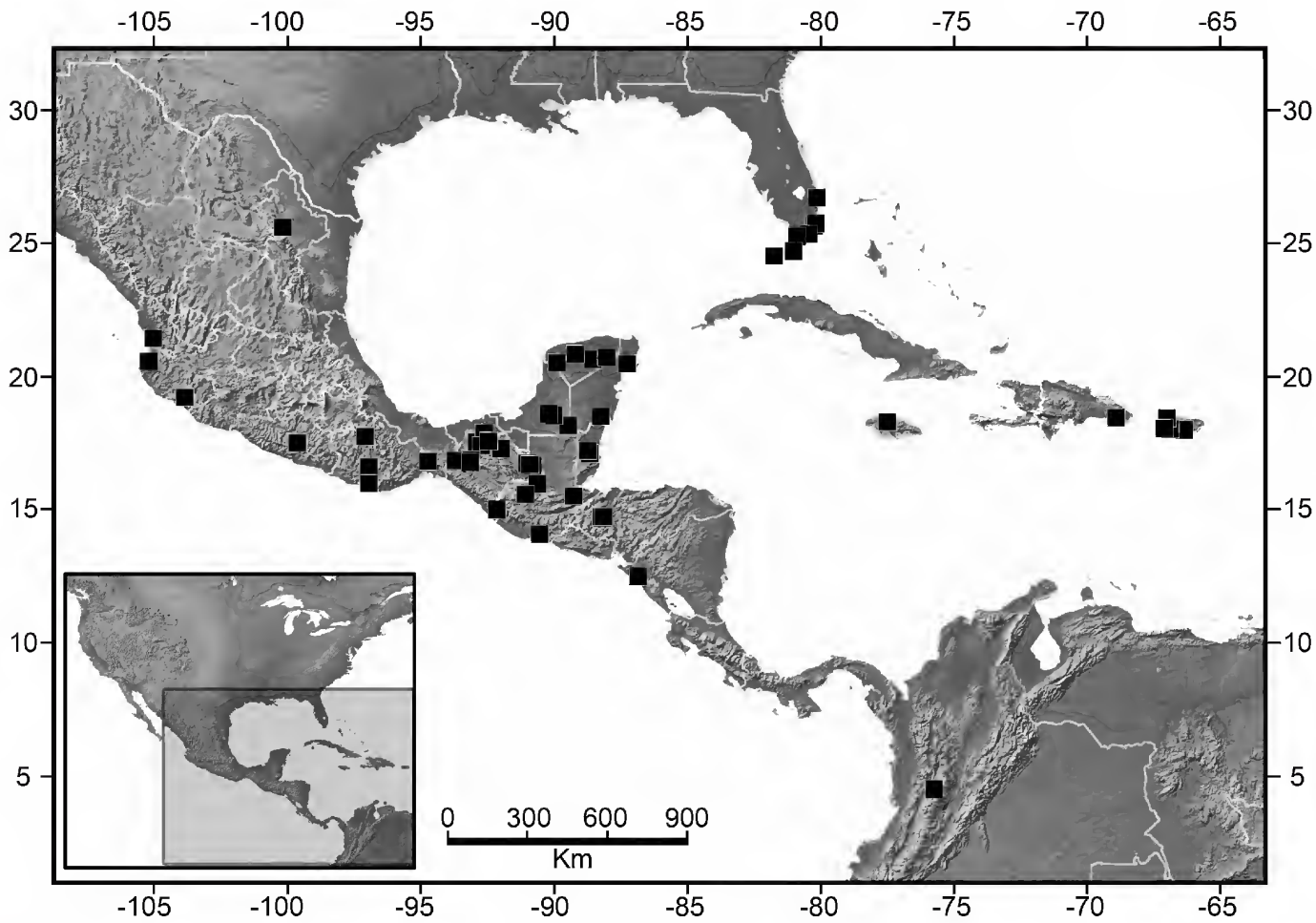

FIG. 5. Map of the Caribbean, Central America and Mexico, plotting known locality records for a cosmopolitan genus of short-tailed whipscorpions, Stenochrus Chamberlin, 1922 (Schizomida: Hubbardiidae Cook, 1899), based on data from museum collections.

average of $360 \mathrm{bp}$. Partial COI sequences varied from 659-1077 bp with an average of $995 \mathrm{bp}$.

The 28S, ITS, 12S, and COI sequences were aligned using MAFFT 6 (Katoh, 2013). Among the aligned loci, $74 \%, 49 \%$, and $48 \%$ of the sites were variable, and $65 \%, 35 \%$, and $41 \%$ parsimony informative, in the $12 \mathrm{~S}$, ITS, and COI, respectively, whereas $9 \%$ were variable and $5 \%$ parsimony informative in the $28 \mathrm{~S}$. As expected, for a protein-coding gene, the third codon position of the COI was the most informative, with $96 \%$ of the sites variable and 91\% parsimony informative, followed by the first codon position, with $34 \%$ of the sites variable and $25 \%$ parsimony informative.

The aligned ITS, 12S, and COI sequences were concatenated together with the $28 \mathrm{~S}$ sequences to produce a matrix of 2968 aligned DNA nucleotides. In the concatenated alignment $45 \%$ of the sites were variable and $36 \%$ parsimony informa- tive. Seven data partitions were identified using PartitionFinder ver. 2 (Lanfear et al., 2016): morphology; ITS; 28S; 12S; and COI first, second, and third positions. jModelTest ver. 2.1.6 (Darriba et al., 2012) was used to select the most appropriate evolutionary model for each molecular partition.

The morphological and molecular data were analyzed separately and simultaneously using Maximum Likelihood with RAxML-HPC2 ver. 8.2.10 on XSEDE (Stamatakis, 2014) via the CIPRES Science Gateway ver. 3.3 online portal (Miller et al., 2010). Optimal trees were computed with 1000 bootstrap replicates and 500 hits for the fast bootstrap replicates, using the GTRCAT model for molecular data and the GTRGAMMA --asc-corr=Lewis for morphological data (Lewis, 2001). Characters were optimized on the preferred phylogenetic hypothesis (fig. 6) with accelerated transformation (ACCTRAN) or delayed transformation (DELTRAN) (Farris, 1970; Swofford 


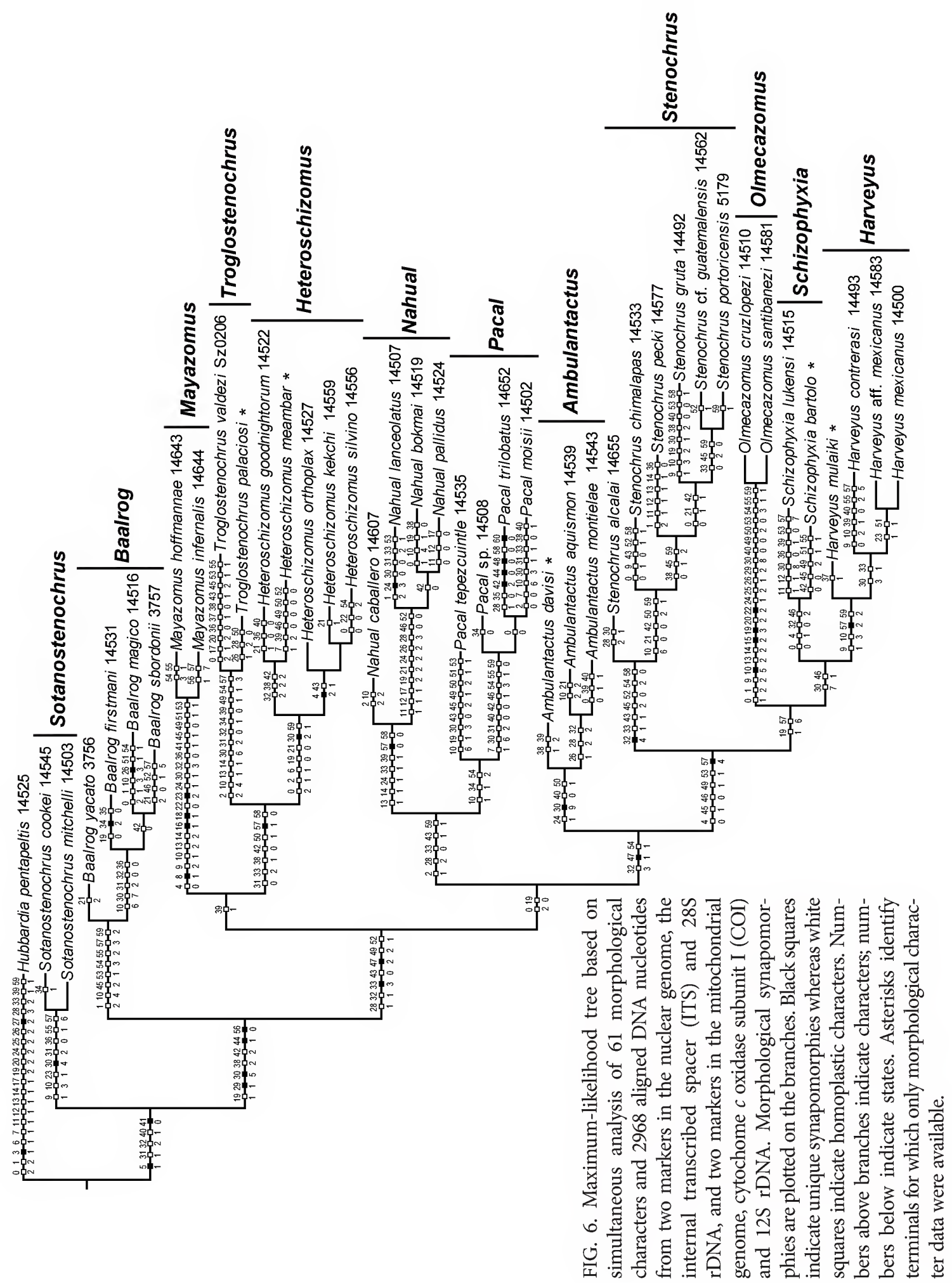


and Maddison, 1987), as appropriate (appendix 1). A more detailed explanation of the molecular and combined phylogenetic analyses will be presented elsewhere (Monjaraz-Ruedas et al., in prep.)

\section{SYSTEMATICS}

Key to Identification of the North American Genera of Hubbardiidae (Schizomida)

1. Cheliceral fixed finger with two teeth between two primary teeth, serrula composed of blunt teeth; pedipalp trochanter without prolateral spur; tarsal spurs symmetric; pygidial flagellum cylindrical, not dorsoventrally compressed $(\hat{\sigma})$, with five flagellomeres $(q)$; spermathecae $(q)$ with one pair of lobes and without chitinized arch.......

Protoschizomidae Rowland, 1975

- Cheliceral fixed finger with three or more teeth between two primary teeth, serrula composed of several hyaline teeth (fig. 12); pedipalp trochanter with prolateral spur; tarsal spurs asymmetric; pygidial flagellum dorsoventrally compressed or globose $(\hat{0})$, with three or four flagellomeres $(q)$; spermathecae ( $q$ ) with two or more pairs of lobes and chitinized arch (figs. 8,9)

.2 (Hubbardiidae Cook, 1899)

2. Pedipalp femur, prolateral surface with four setae (Fvr); opisthosomal segment XII ( $\widetilde{\sigma})$ with conspicuous posterodorsal process; spermathecae $(q)$ with more than three pairs of extremely short, broad, and rounded lobes, clustered in groups.

Hubbardia Cook, 1899

- Pedipalp femur, prolateral surface with three setae (Fvr); opisthosomal segment XII (ô) with or without inconspicuous posterodorsal process; spermathecae ( $q$ ) usually with two or four pairs of long, filiform lobes, not clustered in groups (figs. 8-10).

3. Opisthosomal segment II with four setae; pedipalp femur ( $\hat{o}$ ), setae $F v_{1}$ and $F v_{2}$ forming spiniform setiferous tubercles; prolateral tarsal spur ( $\hat{\sigma})$ present; pygidial flagellum (q) with four flagellomeres. Mayazomus Reddell and Cokendolpher, 1995 - Opisthosomal segment II with two setae; pedipalp femur ( $\delta$ ), setae $F v_{1}$ and $F v_{2}$ acuminate, setiform or spiniform; prolateral tarsal spur (む) absent; pygidial flagellum ( $q$ ) with three flagellomeres.

4. Cheliceral movable finger with lamella or teeth (fig. 12B, C)

- Cheliceral movable finger smooth (fig. 12A).......8

5. Opisthosomal segment XII with small, inconspicuous posterodorsal process $(\hat{\sigma})$; pygidial flagellum $(\hat{\sigma})$ usually globose; spermathecae ( $q$ ), lateral lobes greatly reduced (usually absent) compared to median lobes, and usually with apical bulbs

Pacal Reddell and Cokendolpher, 1995

- Opisthosomal segment XII without posterodorsal process $(\hat{\sigma})$; pygidial flagellum (ठ) dorsoventrally compressed; spermathecae ( $q$ ), lateral and median lobes subequal, without apical bulbs

6. Opisthosomal segments VIII-XI (đ) elongated (fig. 18C); pygidial flagellum (ð) elongated with posterior constriction in dorsal view (fig. 19D-F); spermathecae ( $q$ ), chitinized arch mug shaped (fig. 8E, F).

Heteroschizomus Rowland, 1973, stat. rev.

- Opisthosomal segments VIII-XI ( $\hat{\sigma})$ not elongated (fig. 15); pygidial flagellum ( $\widehat{0}$ ) elliptical or trilobed (figs. 19G-I, 23G-I); spermathecae ( $q$ ), chitinized arch wih lateral tips projected and acute (fig. 9A, B, F)...............7

7. Cheliceral movable finger with lamella (fig. 12C); pedipalp patella with five $P m$ setae, tibia setal formula 5-5-6 (fig. 14C); pygidial flagellum ( $\hat{0}$ ) with pair of dorsosubmedian circular depressions, without projections (fig. 19G-I); spermathecae ( $q$ ), lateral and median lobes equal, with several apical sclerotizations in both pairs of lobes, creating appearence of leafy tree (fig. 9A, B) .Nahual, gen. nov.

- Cheliceral movable finger serrate, comprising several small teeth (fig. 13I); pedipalp 
patella with four $P m$ setae, tibia setal formula 3-3-4 (fig. 14D); pygidial flagellum ( $\hat{\sigma})$ without depressions and with pair of dorsosubmedian projections (fig. 23G-I); spermathecae $(q)$, lateral lobes reduced to approximately $3 / 4$ the length of median lobes, without apical sclerotizations in both pairs of lobes (fig. 9F)

Troglostenochrus, gen. nov.

8. Propeltidium with three pairs of dorsal setae (fig. 11A)

- Propeltidium with two pairs of dorsal setae (fig. 11B) .11

9. Pedipalp tibia with prominent lateral spur; spermathecae ( $q$ ) with four asymmetric pairs of hand-shaped lobes; pygidial flagellum ( $₫$ ) globose, with medial depression. Sotanostenochrus Reddell and Cokendolpher, 1991

- Pedipalp tibia without lateral spur; pygidial flagellum ( $\delta$ ) deltoid/spear shaped (figs. 16D-F, 19A-C), with paired submedian depressions; spermathecae ( $q$ ) with two pairs of filiform lobes.

. .10

10. Pedipalp tibia, setal formula 3-3-5 (fig. 14B); pygidial flagellum ( $\hat{0})$ bulbous/spear shaped, with paired submedian depressions not fused posteriorly (fig. 19A-C); spermathecae $(q)$, median lobes parenthesis shaped, apex laterally directed, median and lateral lobe bases aligned, chitinized arch U-shaped (fig. 9C).

Schizophyxia, gen. nov.

- Pedipalp tibia, setal formula 4-3-5 (fig. 14A); pygidial flagellum ( $\hat{o}$ ) deltoid (fig. 16A-F), with paired posterior depressions fused posteriorly; spermathecae ( $q$ ), median lobes straight, apex vertically directed, median lobe bases posterior to lateral lobe bases, chitinized arch inverse arch shaped (fig. 8A). Ambulantactus, gen. nov.

11. Pedipalps ( $\widehat{\sigma})$ robust; pedipalp femur $(\hat{\sigma})$, setae $F v_{1}$ and $F v_{2}$ forming spiniform setiferous tubercles, $\mathrm{Fe}_{1}, \mathrm{Fe}_{5}, \mathrm{Ter}_{7}$ and $\mathrm{Tir}_{5}$ spiniform; pygidial flagellum ( 0 ) elliptical to lanceolate, with pair of dorsosubmedian depressions fused posteriorly; spermathecae $(q)$, lateral lobes swollen, drop shaped....... Olmecazomus, nom. nov. - Pedipalps ( $\widehat{o}$ ) homeomorphic; pedipalp femur (ठ) , setae $\mathrm{Fe}_{1}, \mathrm{Fe}_{5}, \mathrm{Fv}_{1}, \mathrm{Fv}_{2}, \mathrm{Ter}_{7}$ and $\mathrm{Tir}_{5}$ acuminate, setiform; pygidial flagellum ( $\hat{\sigma})$ ovate, subrhomboidal, or bulbous (figs. $16 \mathrm{G}-\mathrm{I}, 23 \mathrm{D}-\mathrm{F})$, with pair of dorsosubmedian pits or depressions not fused posteriorly; spermathecae ( $q$ ), lateral lobes slender, filiform (figs. 8B, D) . .12

12. Pedipalp trochanter, apical process with bump (fig. 7C, H); pygidial flagellum ( $\tilde{\sigma}$ ) subrhomboidal, and acuminate or lanceolate posteriorly (fig. 19A-C), with pair of shallow dorsosubmedian pits; spermathecae ( $q$ ), lateral lobes at least $2 / 3$ the length of, or longer than, median lobes, and with apical bulbs (fig. 8C, D).

Harveyus, gen. nov.

- Pedipalp trochanter, apical process acute or absent (fig. 7B); pygidial flagellum ( $\widehat{o}$ ) elliptical, cordate or bulbose, and not acuminate or lanceolate posteriorly (fig. 23D-F), with pair of deep dorsosubmedian pits or without dorsal depressions; spermathecae ( $q$ ), lateral lobes at most half the length of median lobes, and without apical bulbs (figs. 8B, 9E) .13

13. Pygidial flagellum ( $\widehat{\partial}$ ) ovate or cordate, with pair of dorsosubmedian pits embedded in dorsomedian depression (fig. 20B); spermathecae $(q)$, median lobes similar width to lateral lobes (fig. 10C), curved laterally (J-shaped or parenthesis shaped) and sclerotized apically, median lobe bases posterior to lateral lobe bases (figs. 9E, 10C).

Stenochrus Chamberlin, 1922

- Pygidial flagellum ( $\widehat{o}$ ) bulbous, without dorsal depressions or pits (fig. 16G-I); spermathecae ( $q$ ), median lobes broader than lateral lobes, slightly curved laterally and apically, and unsclerotized apically (fig. 8B), median and lateral lobe bases aligned (fig. 10A) Baalrog, gen. nov. 
Family Hubbardiidae Cook, 1899

Subfamily Hubbardiinae Cook, 1899

Ambulantactus, gen. nov.

Figures 1, 6, 7A, B, 8A, 10D, 12C, 13A, B, 14C, $15 \mathrm{~A}-\mathrm{C}, 16 \mathrm{~A}-\mathrm{F}, 17 \mathrm{~A}-\mathrm{C}$; tables $1,2,5$

Type Species: Ambulantactus montielae, sp. nov., type species, here designated.

Diagnosis: Ambulantactus, gen. nov., may be separated from other hubbardiid genera by the following combination of characters. Propeltidium anterior process with two anterior setae (one posterior to the other) and three pairs of dorsosubmedian setae (fig. 11A); corneate eyes absent. Metapeltidium entire. Tegument without clavate setae. Cheliceral movable finger smooth; single guard tooth at end of serrula; setal group G3 with G3-3 setae situated anteriorly (fig. 13A, B). Pedipalps homeomorphic; trochanter with mesal spur, apical process small and acute (fig. 7A, B); femur $F v_{1}$ and $F v_{2}$ setae acuminate, $F v r_{1-3}$ setae present; patella with three acuminate $P e$ setae and five feathered $\mathrm{Pm}$ setae; tibia setal formula 4-3-5 (Ter-TmrTir) (fig. 14A). Leg IV femur anterodorsal margin produced at $\mathrm{ca} .90^{\circ}$ angle. Opisthosomal tergite II with one pair of setae $(\mathrm{Dm})$. Opisthosomal segments IX-XII not elongated; XII ( $\widehat{\sigma}$ ) without posterodorsal process. Pygidial flagellum $\left({ }^{\star}\right)$ dorsoventrally compressed, deltoid, with pair of posterodorsal depressions, fused posteriorly (fig. 16A-F); flagellum ( + ) with two annuli (fig. 17AC). Spermathecae ( $q$ ) with two pairs of lobes; lateral lobes slightly smaller than (ca. 3/4 the length) but similar in width to median lobes; both pairs of lobes linear, with apex directed vertically, unsclerotized apically (figs. 8A, 10D), and without bulbs; median lobe bases posterior to lateral lobe bases (fig. 10D), with duct openings; chitinized arch inverse arch shaped, without anterior branch, with lateral tips tapering; gonopod wide and short.

Comparisons: Species of Ambulantactus, gen. nov., are most similar morphologically to species of Schizophyxia, gen. nov. Both genera possess a pair of posterodorsal depressions on the male pygidial flagellum, and the lobes of female sper- mathecae are of similar length. The two genera differ in the shape of the male flagellum, which is deltoid in Ambulantactus, but spear shaped in Schizophyxia. Additionally, the chitinized arch of the female spermathecae is inverse arch shaped in Ambulantactus, but U-shaped in Schizophyxia. Finally, the pedipalp tibia setal formula is 4-3-5 in Ambulantactus and 3-3-4 in Schizophyxia.

Species of Ambulantactus resemble species of Heteroschizomus, stat. rev., and Nahual, gen. nov., in the linear median and lateral lobes of the female spermathecae. However, the lobes are considerably larger in Ambulantactus than in the other genera. Furthermore, the lobes are smooth in Ambulantactus but apically sclerotized in Nahual, and cylindrical in Ambulantactus but conical in Heteroschizomus.

Species of Ambulantactus also resemble species of Olmecazomus, nom. nov., especially Olmecazomus brujo, comb. nov., in the shape of the female spermathecae, and the posterior depressions of the male flagellum. However, Ambulantactus are considerably smaller than Olmecazomus and pedipalp setae $F v_{1}$ and $F v_{2}$ are acuminate setiform in Ambulantactus, but form spiniform setiferous tubercles in Olmecazomus.

Eтymology: The genus name is a compound word derived from the Latin words ambulans, meaning "walking," and tactus, meaning "touch," and refers to the distinctive walking gait of schizomids. It is neuter in gender.

INCLUDED SPECIES: Ambulantactus aquismon, sp. nov.; Ambulantactus davisi (Gertsch, 1940), comb. nov.; Ambulantactus montielae, sp. nov.

Distribution: The known species of $\mathrm{Ambu}$ lantactus, gen. nov., are endemic to Mexico, where they display a disjunct distribution across three states (fig. 1). Ambulantactus montielae, sp. nov., occurs in Morelos, A. aquismon, sp. nov., in San Luis Potosí, and A. davisi, comb. nov., in Tamaulipas. This distribution resembles the distributions of some taxa in family Protoschizomidae, with species occurring in the north and south of Mexico, on either side of the Mexican Transvolcanic Belt. Ambulantactus is probably distributed along the entire length of the Sierra Madre Oriental. 

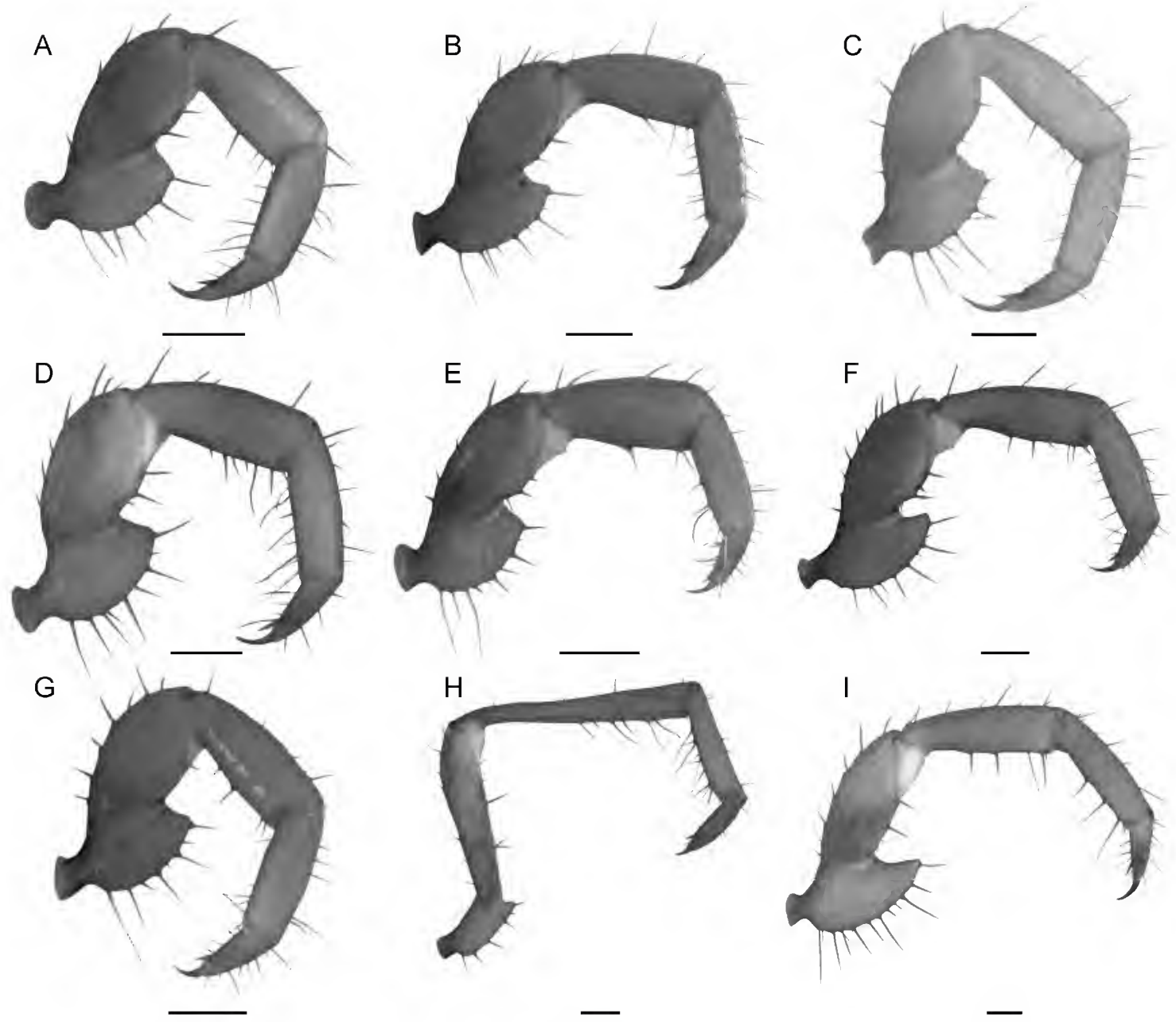

FIG. 7. Short-tailed whipscorpions (Schizomida: Hubbardiidae Cook, 1899), pedipalps, retrolateral view. A. Ambulantactus aquismon, sp. nov., ô (CNAN T1294). B. Ambulantactus montielae, sp. nov., ô (CNAN T1291). C. Baalrog magico (Monjaraz-Ruedas and Francke, 2018), comb. nov., ô (CNAN T1163). D. Harveyus contrerasi, sp. nov., ô (CNAN T1276). E. Heteroschizomus kekchi, sp. nov., ơ (CNAN T1280). F. Nahual bokmai, sp. nov., ơ (CNAN T1282). G. Schizophyxia lukensi (Rowland, 1973), comb. nov., ơ (CNAN Sz25). H. Stenochrus gruta Monjaraz-Ruedas and Francke, 2018, ô (CNAN T1155). I. Troglostenochrus valdezi (Monjaraz-Ruedas, 2012), comb. nov., o (CNAN T698). Scale bars $=0.2 \mathrm{~mm}$. 

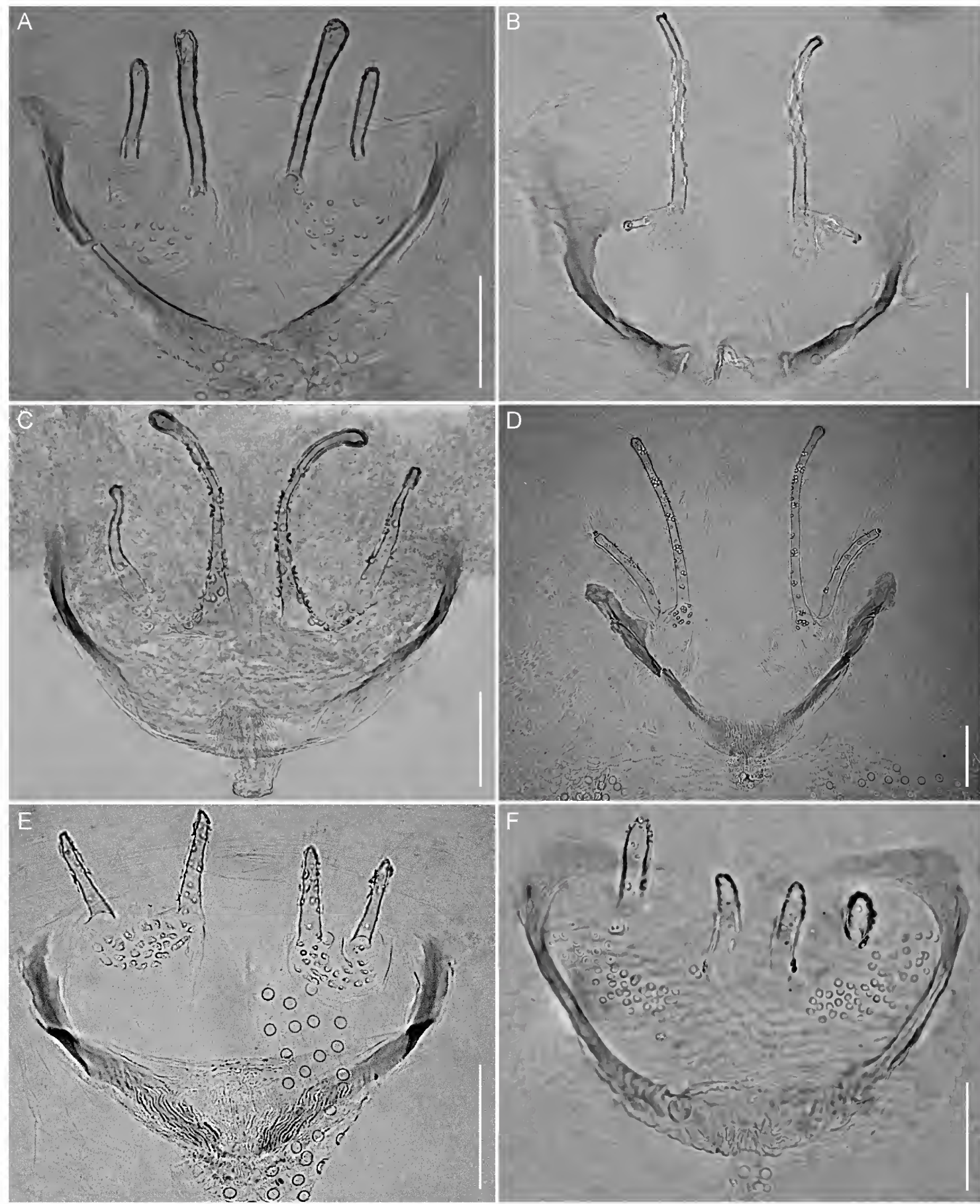

FIG. 8. Short-tailed whipscorpions (Schizomida: Hubbardiidae Cook, 1899), female spermathecae, dorsal view. A. Ambulantactus montielae, sp. nov., + (CNAN T1292). B. Baalrog magico (Monjaraz-Ruedas and Francke, 2018), comb. nov., ㅇ (CNAN T1165). C. Harveyus contrerasi, sp. nov., đิ (CNAN T1278). D. Harveyus mexicanus (Rowland, 1971), comb. nov., ㅇ (CNAN Sz131). E. Heteroschizomus goodnightorum Rowland, 1973, + (CNAN Sz171). F. Heteroschizomus kekchi, sp. nov., $q$ (CNAN T1281). Scale bars $=0.05 \mathrm{~mm}$. 

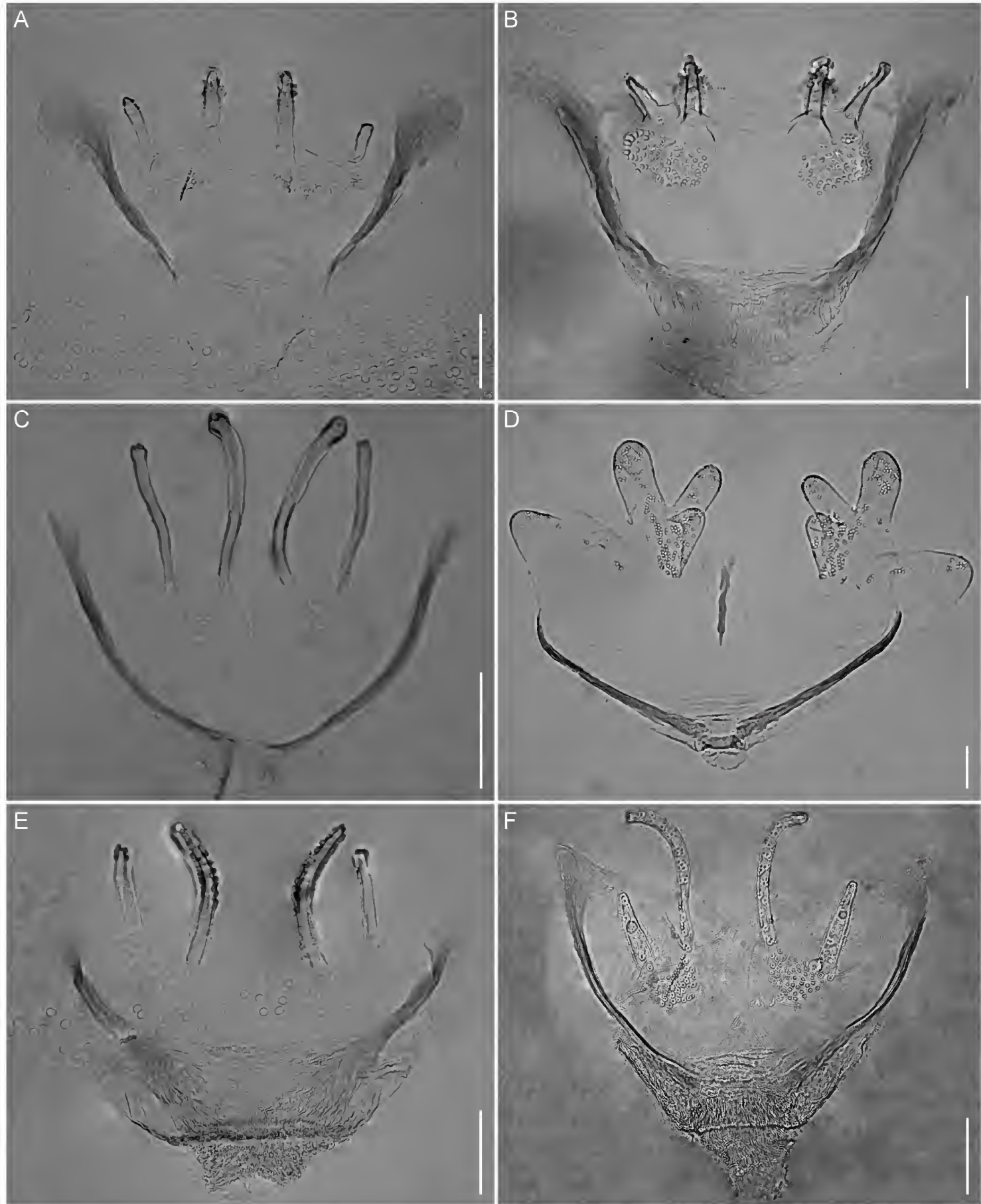

FIG. 9. Short-tailed whipscorpions (Schizomida: Hubbardiidae Cook, 1899), female spermathecae, dorsal view. A. Nahual bokmai, sp. nov., + (CNAN T1283). B. Nahual lanceolatus (Rowland, 1975), comb. nov., ㅇ (CNAN Sz130). C. Schizophyxia lukensi (Rowland, 1973), comb. nov., ㅇ (CNAN Sz25). D. Sotanostenochrus mitchelli (Rowland, 1971), ๆ (CNAN Sz143). E. Stenochrus gruta Monjaraz-Ruedas and Francke, 2018, $q$ (CNAN T1156). F. Troglostenochrus valdezi (Monjaraz-Ruedas, 2012), comb. nov., o (CNAN T699). Scale bars $=0.05 \mathrm{~mm}$. 
Natural History: The species of Ambulantactus, gen. nov., are epigean, occurring under rocks in rainforest and tropical dry forest.

RemARKs: Species of Ambulantactus, gen. nov., closely resemble some species of Schizophyxia, gen. nov., in the general shape of the female spermathecae. Ambulantactus montielae, sp. nov., was designated as the type species of the genus because it is the only species in which the female is known. Despite the absence of females of $A$. aquismon, sp. nov., and A. davisi, comb. nov., and the absence of molecular data for $A$. davisi, the two species grouped with $A$. montielae in the simultaneous analysis (fig. 6).

\section{Ambulantactus aquismon, sp. nov.}

Figures 1, 6, 7B, 13A, 15A, 16A-C; tables 1, 5

Type Material: MeXICO: San Luis Potosí: Municipio de Aquismón: outside Cueva del Espiritu Santo Mantetzulel, 21 $37^{\prime} 36^{\prime \prime} \mathrm{N}$ $99^{\circ} 03^{\prime} 42^{\prime \prime} \mathrm{W}, 461 \mathrm{~m}, 13 . i i .2010$, G. Contreras, J. Cruz, O. Francke, C. Santibañez, and A. Valdez, holotype ô (CNAN T1294).

DiAGNosis: Ambulantactus aquismon, sp. nov., may be distinguished from other species of the genus by the male pygidial flagellum, which is deltoid with an acute posterior margin, and a pair of posterodorsal depressions fused posteriorly into a triangular shape. Ambulantactus aquismon is closely related and morphologically similar to $A$. montielae, sp. nov., but the male pygidial flagellum is more elongated and less bulbous than in $A$. montielae. Additionally, A. aquismon is smaller (3.6 $\mathrm{mm})$ than A. montielae $(4.7 \mathrm{~mm})$; the apical process of the male pedipalp trochanter is obtuse in A. aquismon but acute in A. montielae; and the pedipalp patella bears four $P e$ setae in $A$. aquismon and five in A. montielae.

EтумоLоGy: The specific name is a noun in apposition taken from the name of the municipality in which the type locality is situated.

Description: The following description is based on the holotype male (fig. 15A).
Color: Pale brownish.

Prosoma: Propeltidium with two setae on anterior process; three pairs of dorsal setae; ocular spots distinct. Metapeltidium $0.40 \mathrm{~mm}$ long, $0.59 \mathrm{~mm}$ wide. Anterior sternum with nine setae, plus two sternophysial setae; posterior sternum with six setae.

Chelicerae: Movable finger serrula with 19 teeth, guard tooth present (fig. 13A). Fixed finger with three smaller teeth between two primary teeth; setal group formula, 3-6-4-2-7-10-1-6; G1 with three spatulate setae, covered with small blunt spicules; G2 composed of six feathered setae, subequal, shorter than movable finger; G3 with four setae, subequal, feathered apically and smooth basally; G4 consisting of two small, smooth, thick setae, elongated apically; G5A with seven setae, subequal, feathered apically and longer than fixed finger; G5B with eight feathered setae increasing in size apically; G6 with one smooth seta, ca. half the length of movable finger; G7 with six slender, feathered setae, subequal.

Pedipalps: Pedipalps homeomorphic (fig. 7A); $1.77 \times$ longer than propeltidium. Trochanter without apical process; prolateral surface with small apical spur. Femur $1.93 \times$ longer than high; retroventral margin with $\mathrm{Fe}_{1}, \mathrm{Fe}_{5}$, $\mathrm{Fev} v_{1}$, and $\mathrm{Fev} v_{2}$ setae acuminate; prolateral surface with row of three ventral acuminate setae $\left(F m v_{1-3}\right)$ and two dorsal acuminate setae $\left(F m d_{2}, F m d_{3}\right)$. Patella with three acuminate $P e$ setae and four feathered $P m$ setae; without distinctive armature. Tibia setal formula, 4:3:5; Ter setae acuminate, Tmr and Tir setae feathered. Tarsal spurs asymmetric.

Legs: Leg I basitarsal/telotarsal proportions, 25:5:6:5:-:-:- (broken); IV, femur (missing).

Opisthosoma: Tergite I with two pairs of microsetae anteriorly plus pair of $D m$ setae; II with three pairs of microsetae anteriorly plus pair of $D m$ setae; III-VII each with pair of $D m$ setae; VIII with pairs of $D m$ and $D l_{2}$ setae; IX with pairs of $D l_{1}$ and $D l_{2}$ setae and without pair of $D m$ setae. Segments X and XI telescoped, slightly elongated, with pairs of $\mathrm{Dl}_{2}$, 
A

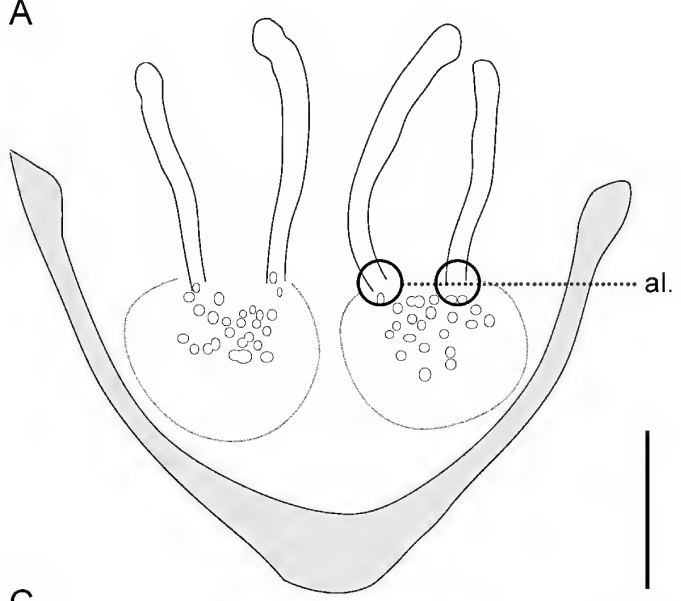

C

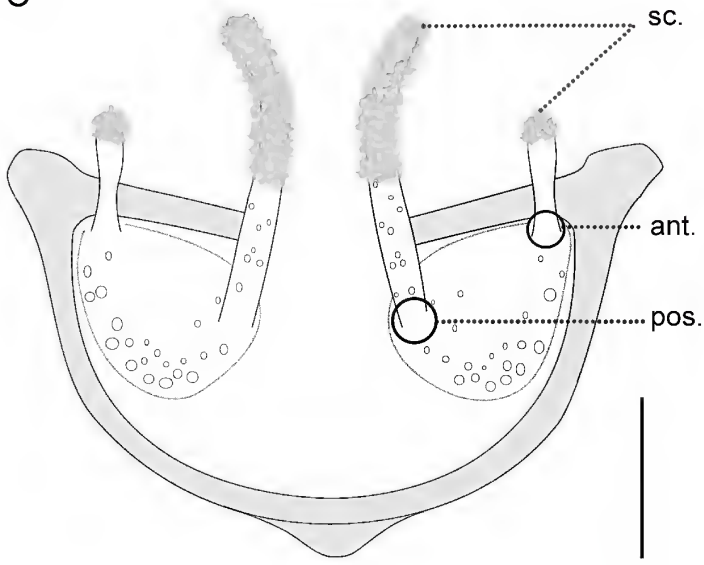

B
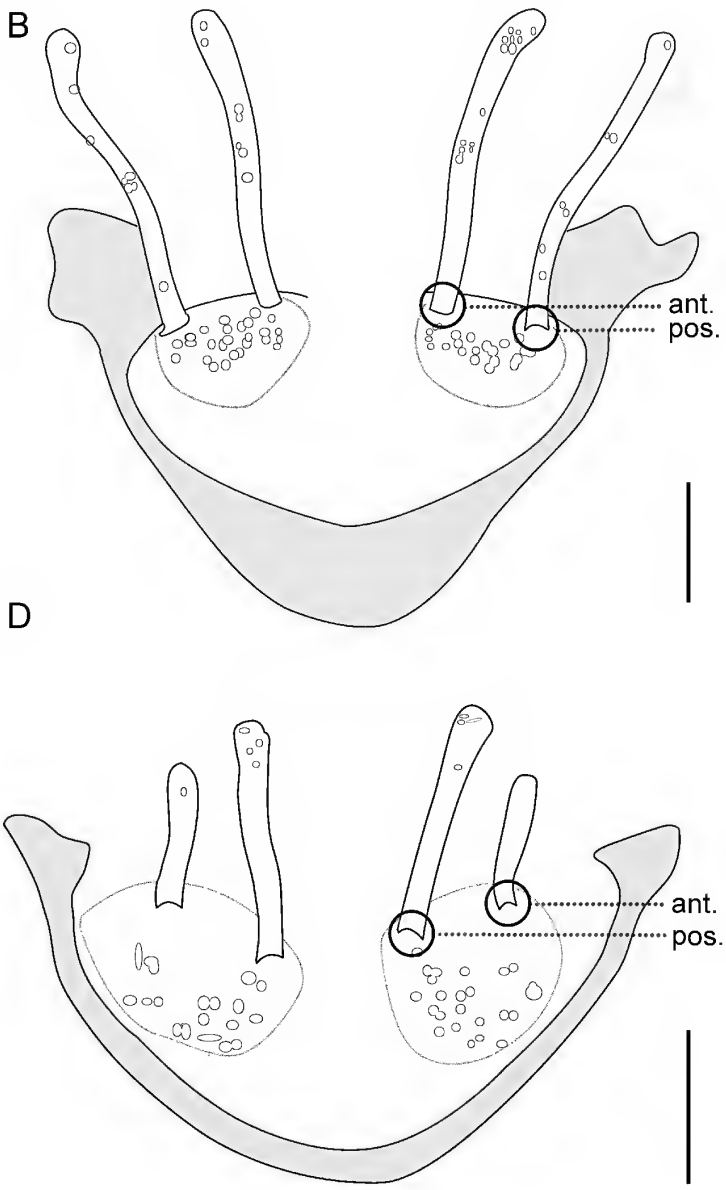

FIG. 10. Short-tailed whipscorpions (Schizomida: Hubbardiidae Cook, 1899), female spermathecae, schematic illustration of lobe base positions. A. Schizophyxia lukensi (Rowland, 1973), comb. nov., \& (CNAN Sz25), aligned. B. Nahual caballero (Monjaraz-Ruedas and Francke, 2018), comb. nov., $q$ (CNAN T1158), anteromedian to lateral. C. Stenochrus portoricensis Chamberlin, 1922, $q$ (CNAN Sz93), posteromedian to lateral. D. Ambulantactus montielae, sp. nov., \& (CNAN T1292), posteromedian to lateral. Abbreviations: al., aligned; ant., anterior; pos., posterior; sc., sclerotizations. Scale bars $=0.05 \mathrm{~mm}$.

$V m_{2}, V l_{1}$, and $V l_{2}$ setae plus single $V m_{1}$ seta; XII with pairs of $D m, D l_{1}, D l_{2}, V m_{1}, V m_{2}, V l_{1}$, and $V l_{2}$ setae, without posterodorsal process. Sternites II-VII each with two irregular rows of setae; genital plate with scattered microsetae.

Pygidial flagellum: Flagellum dorsoventrally compressed, deltoid (fig. 16A-C), with posterior part acute; $1.77 \times$ longer than wide; pair of posterodorsal depressions fused posteriorly; seta $D m_{1}$ situated over bulb base, $D m_{4}$ situated posteriorly over depression, $D l_{2}$ situated anterior to $V l_{1}, D l_{3}$ aligned with $V l_{2}$, pair of $V m_{2}$ setae present, $V m_{1}$ seta aligned with $V m_{2}$, pair of anterodorsal microsetae between $D m_{1}$ and $\mathrm{Dl}_{2}$, pair of anterolateral microsetae on flagellar pedicel, two patches of microsetae between $V l_{1}$ and $V l_{2}$ (msp).

Distribution: Ambulantactus aquismon, sp. nov., is known only from the type locality in the state of San Luis Potosí, Mexico (fig. 1). It is codistributed in San Luis Potosí with species of 
Harveyus, gen. nov., which are primarily cavernicolous. The few epigean species of Harveyus differ markedly from $A$. aquismon in the shape of the male flagellum (the spermathecae are unknown in this species).

Natural History: This epigean species was found under rocks in a primary rainforest near Cueva de Mantetzulel in Aquismón.

Additional Material Examined: MEXICO: San Luis Potosí: Municipio de Aquismón: Cueva del Espiritu Santo Mantetzulel, outside, $21^{\circ} 37^{\prime} 36^{\prime \prime} \mathrm{N} 99^{\circ} 03^{\prime} 42^{\prime \prime} \mathrm{W}, 461 \mathrm{~m}, 13 . i i .2010$, G. Contreras, J. Cruz, O. Francke, C. Santibañez, and A. Valdez, 1 imm. (AMCC [LP 14539]).

\section{Ambulantactus davisi (Gertsch, 1940),} comb. nov.

Schizomus davisi Gertsch, 1940: 1-4, figs. 1-6; Takashima, 1951: 102; Rémy, 1961: 406; Rowland, 1971a: 117; 1973a: 21; 1973c: 135; Brignoli, 1974: 147, 149; Rowland, 1975b: $32,166-169,176-178,181,214-215,218-$ $219,224-225,228-229,366-369,394$, map 5, figs. 157, 177, 211, 292; Rowland and Reddell, 1977: 83; 1979a: 162; 1980: 1, 2, 4, 5, 7-10, 13, 15, 20, figs. 1, 4, 24, 58; Reddell and Cokendolpher, 1995: 2, 4, 105.

Stenochrus davisi: Reddell and Cokendolpher, 1991: 18; 1995: 4, 18, 102, 105, 106; Vázquez-Rojas, 1995: 34; 1996: 65; Ruíz and Coronado, 2002: 67; Harvey, 2003: 123; Zawierucha et al., 2013: 359; Moreno-González et al., 2014: 21; Palacios-Vargas et al., 2015: 45; Monjaraz-Ruedas and Francke, 2018: 212.

Type Material: Schizomus davisi: MEXICO: Tamaulipas: Municipio de San Fernando, 28. iii.1937, L. Irby Davis, holotype ô (AMNH).

REMARKs: The precise location of the type locality of A. davisi, comb. nov., is unclear and it is unknown whether the species is epigean or associated with a cave or riparian area like Harveyus mulaiki (Gertsch, 1940), comb. nov. Fresh material could not be collected for the present study.
Ambulantactus montielae, sp. nov.

Figures 1, 6, 7B, 8A, 10D, 12A, 13B, 14A, 15B, C, 16D-F, 17A-C; tables 1,5

Type Material: MEXICO: Morelos: Municipio de Tepalcingo: REBIOSH, El Limón de Cuachichinola, $18^{\circ} 32^{\prime} 33^{\prime \prime} \mathrm{N} 98^{\circ} 56^{\prime} 19^{\prime \prime} \mathrm{W}, 1290 \mathrm{~m}$, 30.vi.2014, M. Mendez-Acuña, E. Tinoco, and N. Ángel, holotype ơ (CNAN T1291), 2.vi.2013, M. Mendez and M. Salas-Rod, paratype $q$ (CNAN T1292). Municipio de Tlalquiltenango: Quilamula, $18^{\circ} 29^{\prime} 38^{\prime \prime} \mathrm{N} 99^{\circ} 00^{\prime} 14^{\prime \prime} \mathrm{W}, 1229 \mathrm{~m}, 30$. viii.2015, M. Mendez-Acuña and M. Salas, paratype $\delta$ (CNAN T1293).

Diagnosis: Ambulantactus montielae, sp. nov., may be distinguished from other species of the genus by the small, projected and acute apical process of the male pedipalp trochanter; the male pygidial flagellum, which is bulbous/deltoid with a pair of posterodorsal depressions fused posteriorly into a triangular shape; and the female spermathecae, in which both pairs of lobes are linear, the lateral pair slightly shorter than the median lobes (ca. 3/4), and the chitinized arch inverse arch shaped. Ambulantactus montielae differs from $A$. aquismon, sp. nov., in the larger size (4.7 $\mathrm{mm}$ vs. $3.6 \mathrm{~mm}$ ); the projected apical process of the pedipalp trochanter; and the wider, more bulbous pygidial flagellum of the male, in which the posterior margin is short and obtuse.

Eтymology: The specific epithet is a patronym, honoring Griselda Montiel Parra, Assistant Curator of CNAN, who collected the first samples of this species and encouraged her students to continue searching until adult males and females were collected.

Description: The following description is based on the holotype male and paratype female (fig. 15B, C).

Color: Pale brownish.

Prosoma: Propeltidium with two setae on anterior process; three pairs of dorsal setae; ocular spots indistinct. Metapeltidium $0.40 \mathrm{~mm}$ long, $0.70 \mathrm{~mm}$ wide. Anterior sternum with 11 setae, plus two sternophysial setae; posterior sternum with six setae. 


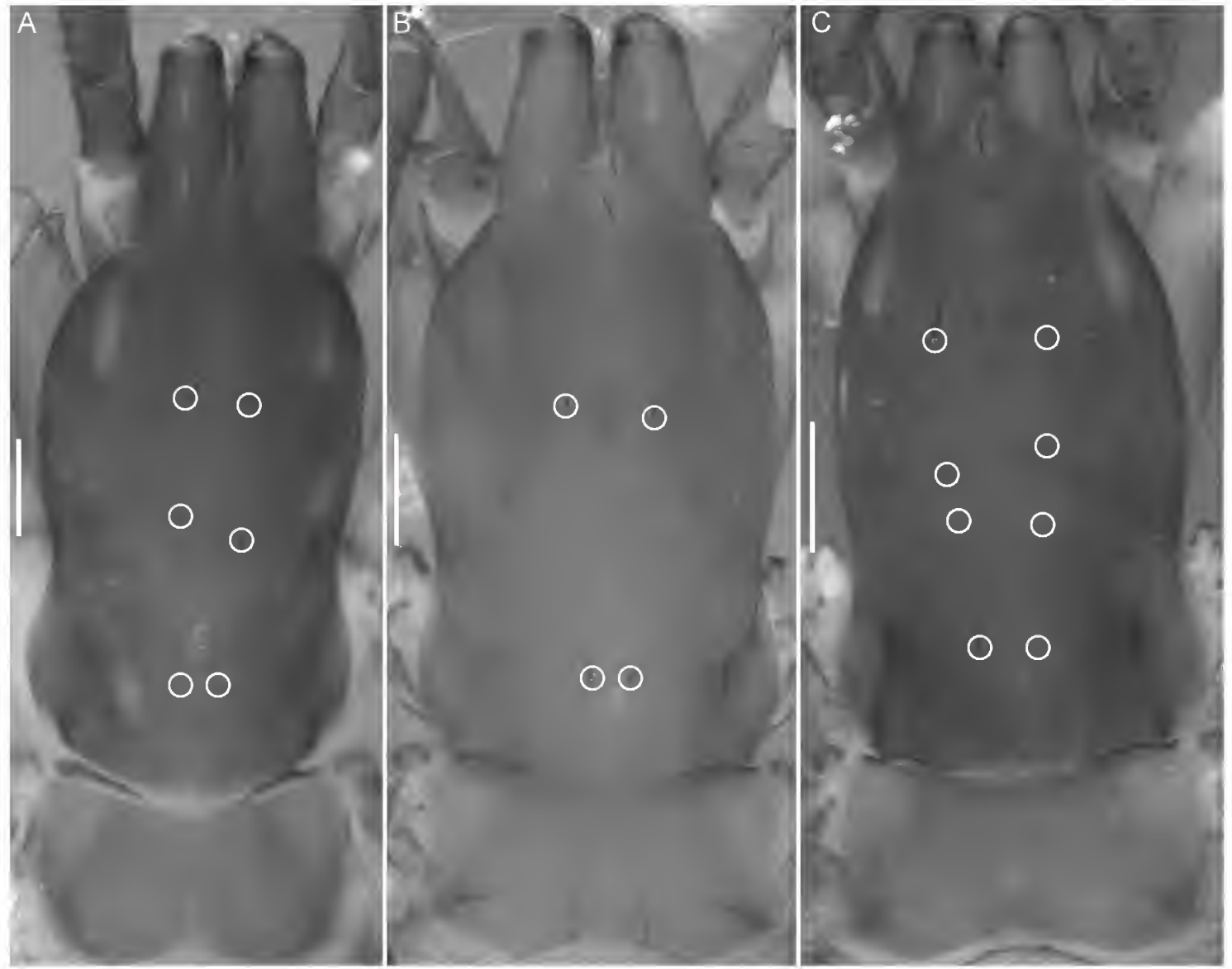

FIG. 11. Short-tailed whipscorpions (Schizomida: Hubbardiidae Cook, 1899), propeltidia, dorsal view, illustrating dorsal setae. A. Nahual bokmai, sp. nov., ô (CNAN T1282). B. Harveyus contrerasi, sp. nov., ô (CNAN T1276). C. Heteroschizomus kekchi, sp. nov., ô (CNAN T1280). Scale bars $=0.2 \mathrm{~mm}$.

Chelicerae: Movable finger serrula with $14(q)$ or $26(\hat{0})$ teeth, guard tooth present (fig. 13B). Fixed finger with three $(q)$ or four $(\delta)$ smaller teeth between two primary teeth; setal group formula, 3-6-4-2-10-8-1-6 (ठ) or 3-6-4-2-7-10-1-6 ( + ); G1 with three spatulate setae, covered with few small spicules; G2 composed of six feathered setae, subequal, shorter than movable finger; G3 with four setae, subequal, feathered apically and smooth basally; G4 comprising two small, smooth, thick setae, elongated apically; G5A with 10 setae, subequal, feathered apically and longer than fixed finger; G5B with eight feathered setae increasing in size apically; G6 with one smooth seta, ca. 1/2 the length of movable finger; G7 with six slender, feathered setae, subequal.

Pedipalps: Pedipalps homeomorphic (figs. 7B, $15 \mathrm{~B}) ; 1.62 \times(\AA)$ or $1.52 \times(q)$ longer than propeltidium. Trochanter apical process with small protuberance; prolateral surface with small medial spur. Femur $1.94 \times$ longer than high; retroventral margin with $\mathrm{Fe}_{1}, \mathrm{Fe}_{5}, \mathrm{Fev} \mathrm{v}_{1}$, and $\mathrm{Fev} \mathrm{v}_{2}$ setae acuminate; prolateral surface with row of three ventral acuminate setae $\left(F m v_{1-3}\right)$ and two dorsal acuminate setae $\left(F m d_{2}, F m d_{3}\right)$. Patella with three acuminate $P e$ setae and five feathered $P m$ setae; without distinctive armature. Tibia setal formula, 4:3:5; Ter setae acuminate, Tmr and Tir setae feathered. Tarsal spurs asymmetric. 
Legs: Leg I, basitarsal-telotarsal proportions, 30:4:5:5:6:7:13; IV, femur 4.4× longer than high.

Opisthosoma: Tergite I with two pairs of microsetae anteriorly plus pair of $D m$ setae; tergite II with three pairs of microsetae anteriorly plus pair of $D m$ setae; III-VII each with one pair of $D m$ setae; VIII with pairs of $D m$ and $D l_{2}$ setae; IX with pairs of $D l_{1}$ and $\mathrm{Dl}_{2}$ setae and without pair of $\mathrm{Dm}$ setae. Segments $\mathrm{X}$ and $\mathrm{XI}$ telescoped, slightly elongated, with pairs of $D l_{2}, V m_{2}, V l_{1}$, and $V l_{2}$ setae plus single $V m_{1}$ seta; XII with pairs of $D m, D l_{1}, D l_{2}, V m_{1}, V m_{2}, V l_{1}$, and $V l_{2}$ setae, without posterodorsal process. Sternites II-VII each with two irregular rows of setae; genital plate with scattered microsetae.

Pygidial flagellum: Flagellum ( compressed, deltoid (fig. 16D-F); 1.75× longer than wide; pair of posterodorsal depressions fused posteriorly; seta $D m_{1}$ situated over bulb base, $D m_{4}$ situated posteriorly over depression, $D l_{2}$ situated anterior to $V l_{1}, D l_{3}$ aligned with $V l_{2}$, pair of $V m_{2}$ setae present, $V m_{1}$ situated posterior to $V m_{2}$, pair of anterodorsal microsetae between $D m_{1}$ and $D l_{2}$, pair of anterolateral microsetae on flagellar pedicel, two patches of microsetae between $V l_{1}$ and $V l_{2}$ (msp). Flagellum ( $q$ ) with three flagellomeres (fig. 17AC); seta $\mathrm{Dl}_{2}$ not reduced, situated anterior to $\mathrm{Vl}_{1}, \mathrm{Dl}_{3}$ situated posterior to $V l_{2}, V m_{2}$ present, reduced, $V m_{1}$ aligned with $V m_{2} ; D l_{1}$ and $D l_{4}$ microsetae present.

Female spermathecae: Two pairs of lobes (fig. 8A); median and lateral lobes linear, similar in width, with few apical duct openings; lateral lobes shorter than median lobes (ca. 3/4); median lobe bases posterior to lateral lobe bases. Chitinized arch cup shaped; anterior branch absent; lateral tip lobed. Gonopod small, conical; length ca. $2 \times$ width.

Distribution: Ambulantactus montielae, sp. nov., is known only from the Reserva de la Biosfera Sierra Huautla, in the state of Morelos, Mexico (fig. 1).

Natural History: This species inhabits tropical dry forest in the Sierra Huautla, where it is often associated with small rivers. It has also been collected under rocks in the shadow of Bursera Jacq. ex L., 1762, plants.
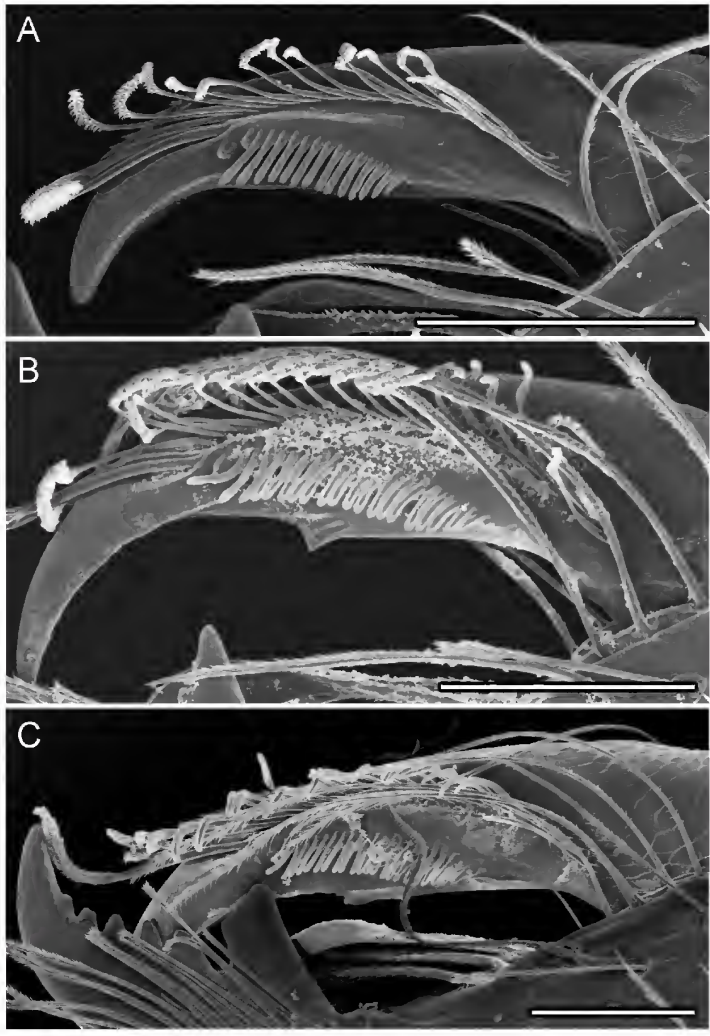

FIG. 12. Short-tailed whipscorpions (Schizomida: Hubbardiidae Cook, 1899), cheliceral movable fingers, prolateral view, illustrating proventral ornamentation: A. Ambulantactus montielae, sp. nov., ô (CNAN T1291), smooth. B. Nahual caballero (Monjaraz-Ruedas and Francke, 2018) comb. nov., $\hat{0}$ (CNAN T1157), one tooth. C. Baalrog magico (Monjaraz-Ruedas and Francke, 2018), comb. nov., ot (CNAN T1163), lamella. Scale bars $=100 \mu \mathrm{m}$.

Additional Material Examined: MEXICO: Morelos: Municipio de Tlalquiltenango: Quilamula, $18^{\circ} 29^{\prime} 38^{\prime \prime} \mathrm{N} 99^{\circ} 00^{\prime} 14^{\prime \prime} \mathrm{W}, 1229 \mathrm{~m}$, 29.viii.2015, M. Mendez-Acuña, 1 imm. (CNAN Sz193), 30.viii.2015, M. Mendez-Acuña and M. Salas, 2 imm. (CNAN Sz194), 10.ix.2016, F. PiloGarcia, M. Mendez-Acuña, D. Rebollo-Salinas, and V. Garcia-Marquez, 2 subad. $q$, $4 \mathrm{imm}$. (CNAN Sz195), 3 imm. (AMCC [LP 14543]), 18.ix.2016, F. Pilo-Garcia, M. Mendez-Acuña, D. Rebollo-Salinas, and V. Garcia-Marquez, $10 \mathrm{imm}$. (CNAN Sz196). 

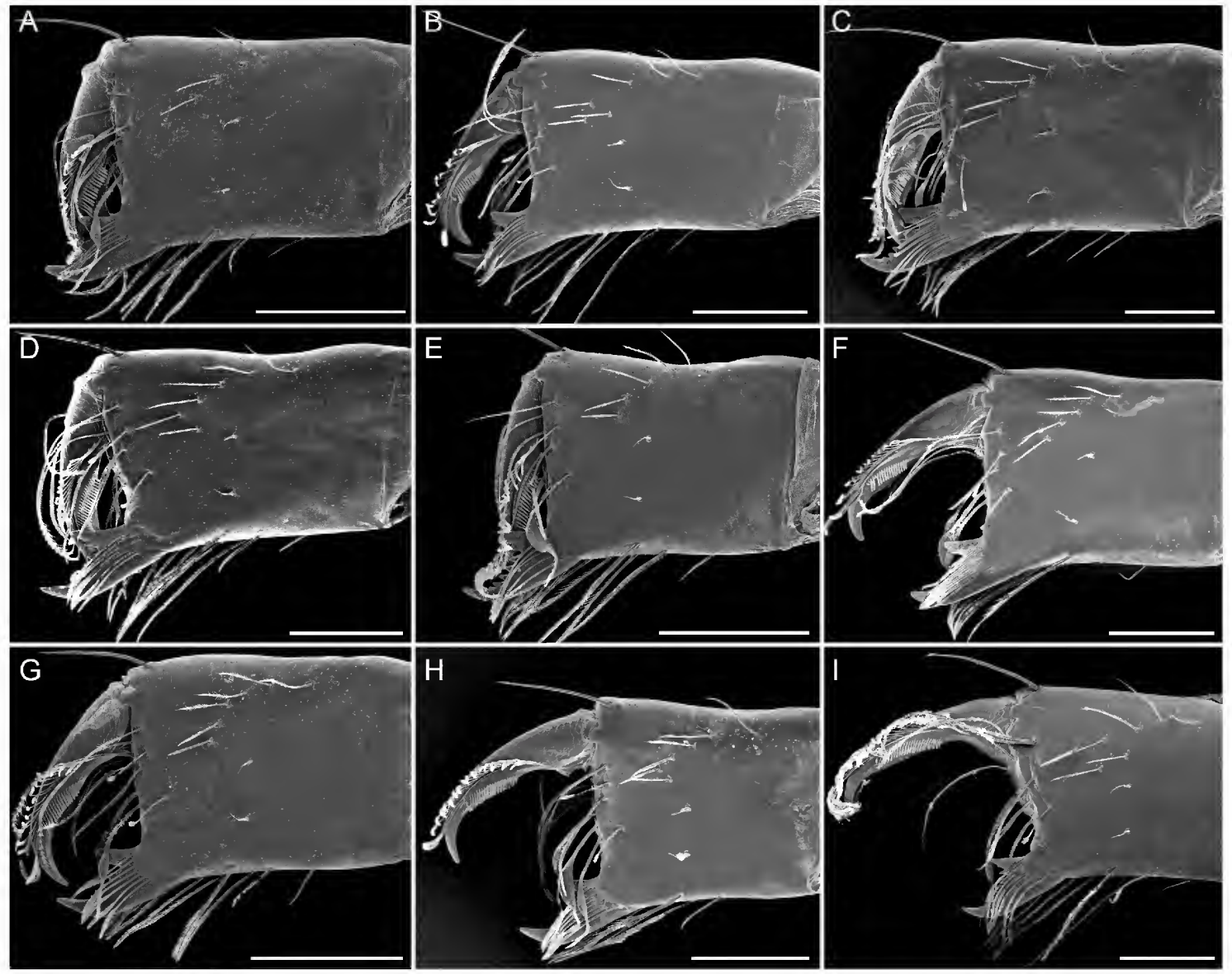

FIG. 13. Short-tailed whipscorpions (Schizomida: Hubbardiidae Cook, 1899), chelicerae, prolateral view: A. Ambulantactus aquismon, sp. nov., ô (CNAN T1294). B. Ambulantactus montielae, sp. nov., ô (CNAN T1291). C. Baalrog magico (Monjaraz-Ruedas and Francke, 2018), comb. nov., ô (CNAN T1163). D. Harveyus contrerasi, sp. nov., ô (CNAN T1276). E. Heteroschizomus kekchi, sp. nov., o (CNAN T1280). F. Nahual bokmai, sp. nov., ô (CNAN T1282). G. Schizophyxia lukensi (Rowland, 1973), comb. nov., ơ (CNAN Sz25). H. Stenochrus gruta Monjaraz-Ruedas and Francke, 2018, §ै (CNAN T1155). I. Troglostenochrus valdezi (Monjaraz-Ruedas, 2012), comb. nov., ơ (CNAN T698). Scale bars $=200 \mu \mathrm{m}$.

\section{Baalrog, gen. nov.}

Figures 2, 6, 7C, 8B, 12C, 13C, 14B, 15D, E, 16G-I, 17D-F; tables 1, 2

Stenochrus (part): Reddell and Cokendolpher, 1991: 1, 3.

Schizomus pecki group (part): Rowland 1975b: $37,39,135,137,167,168,188,209,232$, $233,236,238,241,246,248,250,252,255$, $320,321,348-350,376,390,396,397$;
Rowland and Reddell, 1979a: 165, 171; 1979b: 90, 107; 1980: 1, 3, 22-26, 28, 29, 31; Reddell, 1981: 126; Rowland and Reddell, 1981: 19, 20; Cokendolpher and Reddell, 1984b: 242; Reddell and Cokendolpher, 1986: 34, 37; Camilo and Cokendolpher, 1988: 53; Reddell and Cokendolpher, 1991: 1, 3; 1995: 101-103; Monjaraz-Ruedas and Francke, 2015: 452; 2016 : 781, 783; 2018: 189, 212. 
Type Species: Schizomus firstmani Rowland, 1973 [= Baalrog firstmani (Rowland, 1973), comb. nov.], type species, here designated.

DiAGNosis: Baalrog, gen. nov., may be separated from other hubbardiid genera by the following combination of characters. Cheliceral movable finger smooth (fig. 12A); single guard tooth at end of serrula; setal group G3 with G3-4 setae situated posteriorly (except in $B$. magico, comb. nov.) (fig. 13C). Propeltidium anterior process with two anterior setae (one posterior to the other) and three pairs of dorsosubmedian setae (fig. 11A); corneate eyes absent. Metapeltidium entire. Tegument without clavate setae. Pedipalps homeomorphic; trochanter with mesal spur, without apical process (fig. 7C); femur $F v_{1}$ and $F v_{2}$ setae acuminate, $F v r_{1-3}$ setae present; patella with four acuminate Pe setae and four or five feathered $P m$ setae; tibial setal formula 3-3-5 (Ter-Tmr-Tir) (fig. 14B). Leg IV femur anterodorsal margin produced at $\mathrm{ca} .90^{\circ}$ angle. Opisthosomal tergite II with one pair of setae $(D m)$. Opisthosomal segments IX-XII not elongated; XII ( $\hat{\sigma})$ without posterodorsal process. Pygidial flagellum $(\hat{\sigma})$ bulbose, without dorsal depressions (fig. 16G-I); flagellum ( $q$ ) with two annuli (fig. 17D-F). Spermathecae ( $q$ ) with two pairs of lobes; lateral lobes linear, smaller than (ca. $1 / 4$ to $1 / 3$ the length) and considerably narrower than median lobes, mostly unsclerotized apically; median lobes slightly curved apically (ca. $60^{\circ}$ to $70^{\circ}$ angle), with apex directed laterally, inverse J-shaped, unsclerotized apically (fig. 8B) and without bulbs; median lobe bases anterior to lateral lobe bases (fig. 10B), with duct openings; chitinized arch hastate, without anterior branch, with lateral tips long and diffuse; gonopod wide and short.

Comparisons: Species of Baalrog, gen. nov., resemble species of Stenochrus in the general shape of the female spermathecae. However, the lateral lobes of the spermathecae are narrower than the median lobes, the median lobes are curved apically and unsclerotized, and the median lobe bases situated anterior to the lateral lobe bases in Baalrog, whereas the lateral lobes are the same width as the median lobes, the median lobes curved along their entire length and apically scler-
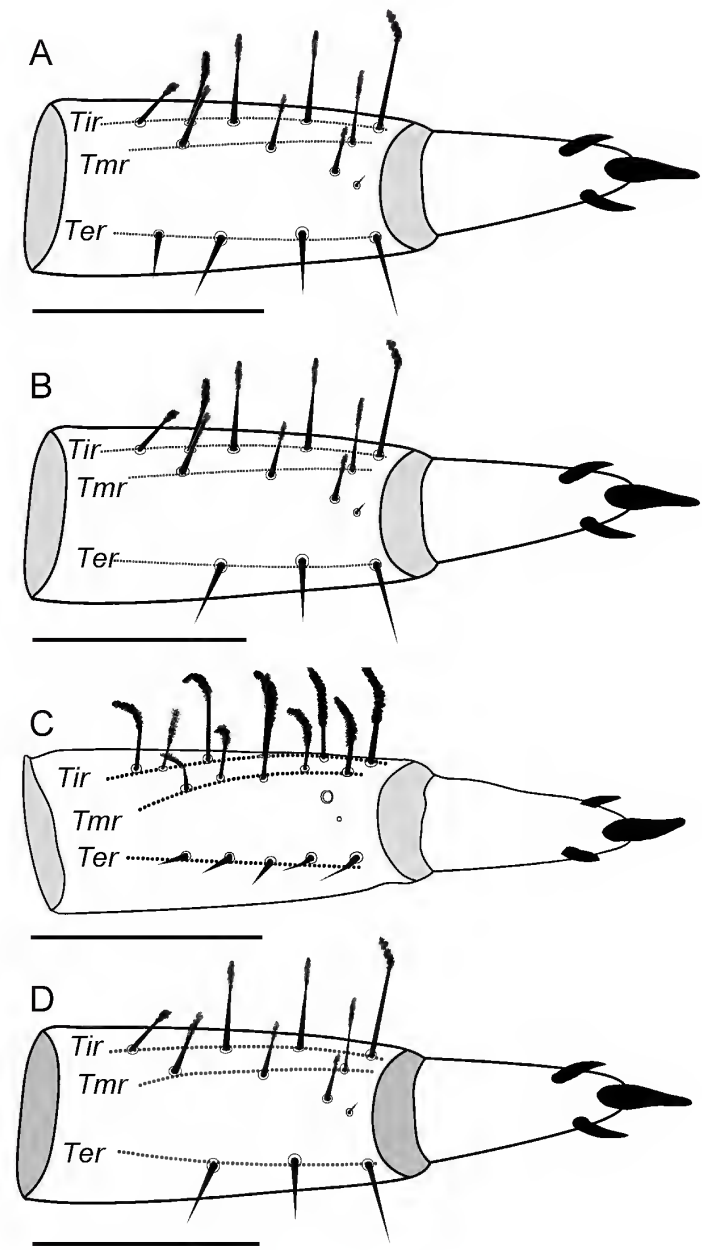

FIG. 14. Short-tailed whipscorpions (Schizomida: Hubbardiidae Cook, 1899), pedipalp tibiae, ventral view, illustrating setal patterns: A. Ambulantactus montielae, sp. nov., ô (CNAN T1291), 4-3-5. B. Baalrog magico (Monjaraz-Ruedas and Francke, 2018), comb. nov., ô (CNAN T1163), 3-3-5. C. Nahual lanceolatus (Rowland, 1975), comb. nov. ô (CNAN Sz130), 5-5-6. D. Stenochrus pecki (Rowland, 1973), ơ (CNAN Sz40), 3-3-4. Scale bars $=0.2 \mathrm{~mm}$.

otized, and the median lobe bases situated posterior to the lateral lobe bases in Stenochrus. Additionally, the male pygidial flagellum is bulbous in Baalrog, but dorsoventrally compressed and cordate to elliptical in Stenochrus. Finally, the pedipalp patella and tibia are more setose, with 5 $P m, 4 P e$, and 5 Tir setae, in Baalrog, than in Stenochrus, with $3 \mathrm{Pm}, 3 \mathrm{Pe}$, and 4 Tir setae. 

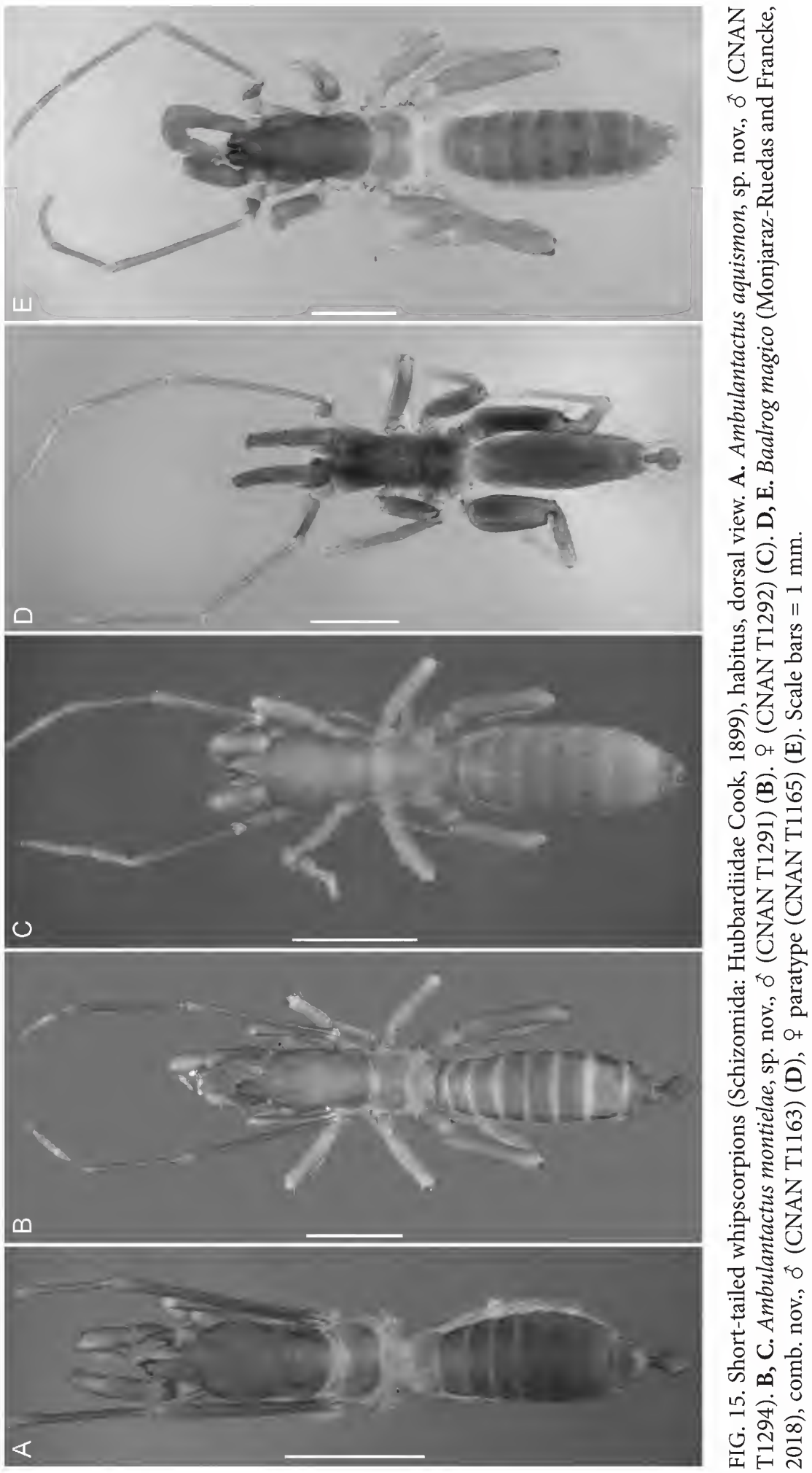
A

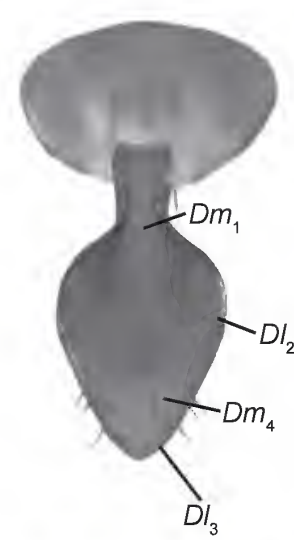

D

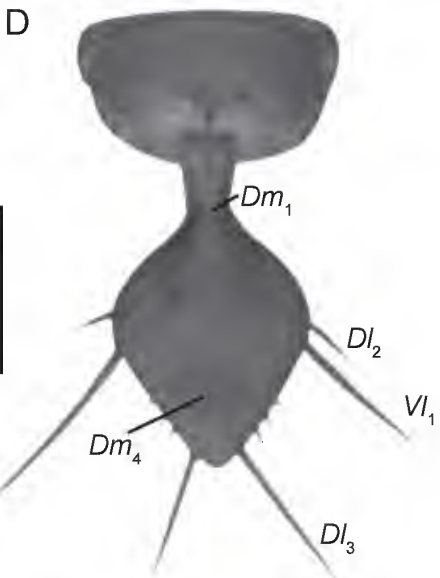

G

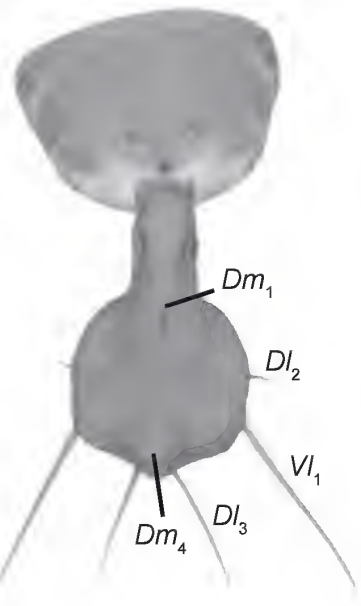

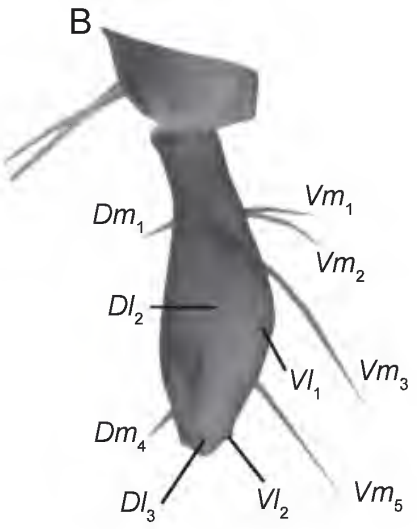

$E$
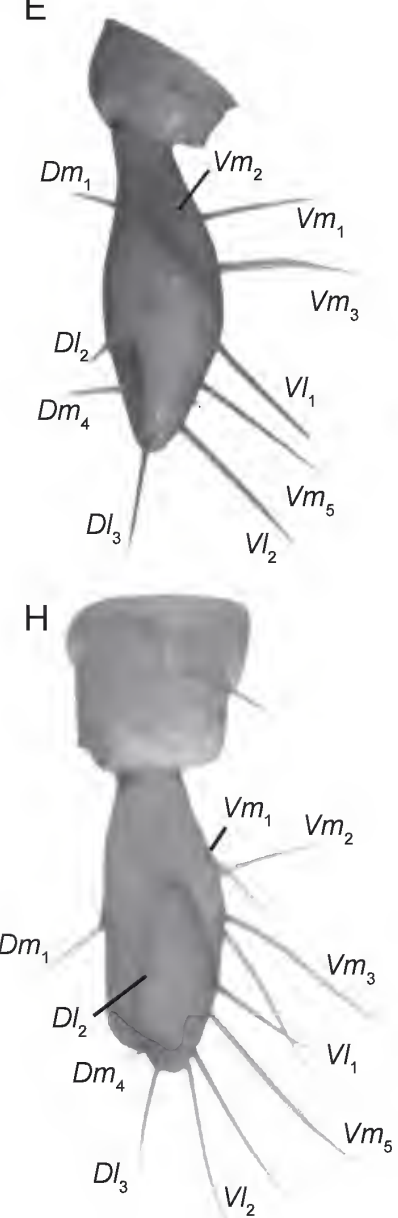

C

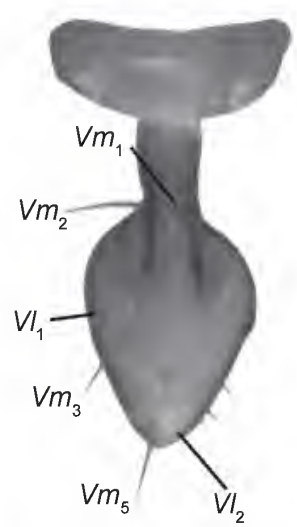

$\mathrm{F}$

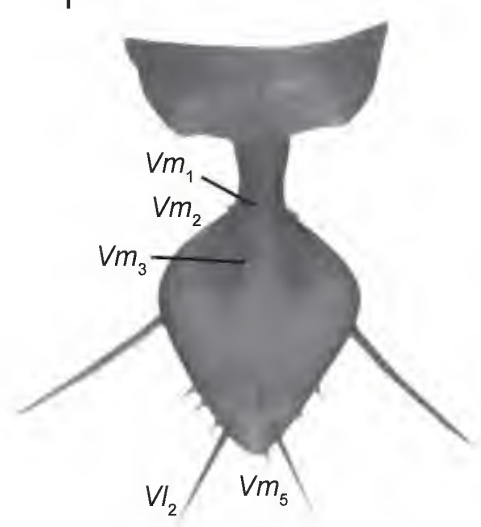

I

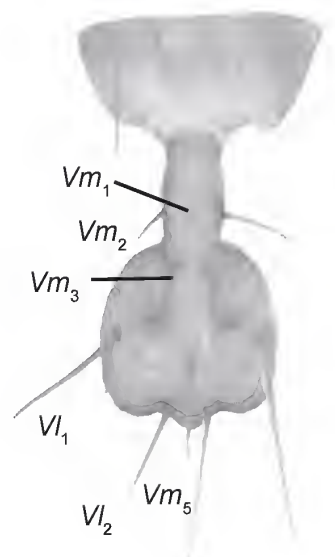

FIG. 16. Short-tailed whipscorpions (Schizomida: Hubbardiidae Cook, 1899), pygidial flagellum, dorsal (A, D, G), lateral (B, E, H) and ventral (C, F, I) views. A-C. Ambulantactus aquismon, sp. nov., ô (CNAN T1294). D-F. Ambulantactus montielae, sp. nov., ô (CNAN T1291). G-I. Baalrog magico (Monjaraz-Ruedas and Francke, 2018), comb. nov., ô (CNAN T1163). Scale bars $=0.2 \mathrm{~mm}$. 

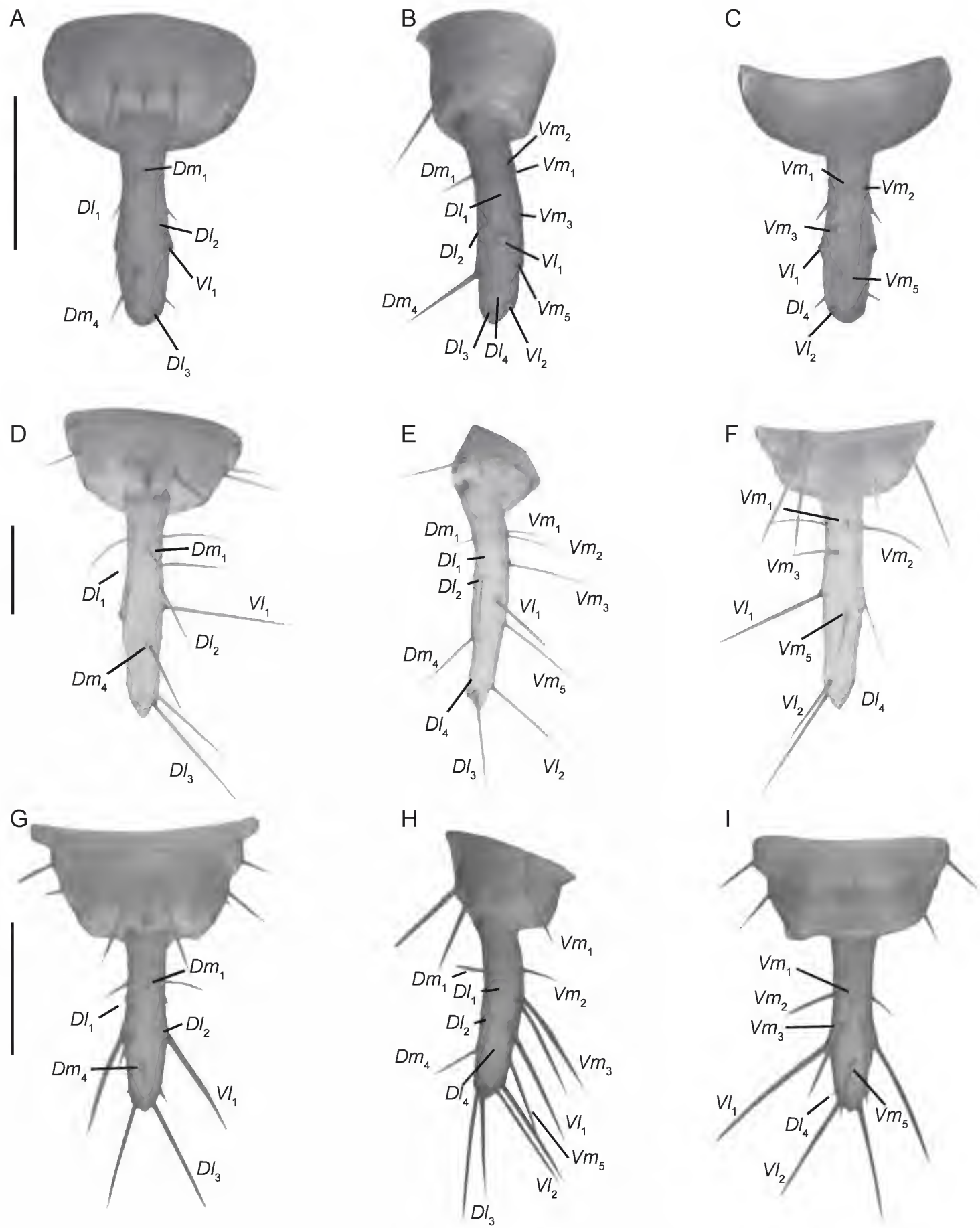

FIG. 17. Short-tailed whipscorpions (Schizomida: Hubbardiidae Cook, 1899), pygidial flagellum, dorsal (A, D, G), lateral (B, E, H) and ventral (C, F, I) views. A-C. Ambulantactus montielae, sp. nov., \& (CNAN T1292). D-F. Baalrog magico (Monjaraz-Ruedas and Francke, 2018), comb. nov., \& (CNAN T1165). G-I. Harveyus contrerasi, sp. nov., o (CNAN T1278). Scale bars $=0.2 \mathrm{~mm}$. 
ETymology: The genus name is a compound word derived from two different words. Baal is a Mayan word for "devil." "Balrogs" are fictitious demons from the "Legendarium" and "The Lord of the Rings" by J.R.R. Tolkien. It is masculine in gender.

INCLUDED SPECIES: Baalrog firstmani (Rowland, 1973), comb. nov.; Baalrog magico (Monjaraz-Ruedas and Francke, 2018), comb. nov.; Baalrog sbordonii (Brignoli, 1973), comb. nov.

Distribution: Species of Baalrog, gen. nov., are endemic to Mexico, inhabiting the caves of central Veracruz, in the Sierra de Zongolica and the foothills of Pico de Orizaba, and extending southward to Huautla de Jimenez, part of the Sierra Madre Oriental, in northern Oaxaca.

Natural History: Baalrog, gen. nov., is a strictly cavernicolous genus, some of its species occurring at great depths, e.g., B. magico, comb. nov., from the Sistema Huautla, one of the deepest cave systems in the world (Steele and Smith, 2012). Although exhibiting a similar distribution in central Veracruz, species of Nahual, gen. nov., are epigean, unlike species of Baalrog.

REMARKs: Rowland and Reddell (1980) created the pecki group of Schizomus to accommodate S. firstmani and S. sbordonii, based on their larger body size and distinct pedipalp morphology. Additionally, the lateral lobes of the female spermathecae, mistakenly reported as absent by Rowland and Reddell (1980), are extremely reduced (fig. 8B). The discovery of $S$. magico revealed the unique bulbous pygidial flagellum of the male. The lateral lobes of the spermathecae are unusually variable in size in this species (Monjaraz-Ruedas and Francke, 2018: 210, fig. 70). These characters are diagnostic for Baalrog, gen. nov.

Cokendolpher and Reddell (1984b) described the male of $S$. sbordonii based on specimens collected in Grutas de Atoyac, Veracruz, although the holotype female was collected in Cueva de Ojo de Agua Grande in Paraje Nuevo, Veracruz. After detailed examination of the specimens, which revealed new morphological differences, and a comparison of DNA sequences, it was determined that material from Atoyac is not conspecific with material from the type locality. The population at Atoyac is described below as Baalrog yacato, sp. nov. Although the bulbose pygidial flagellum of the male of $B$. yacato differs markedly from the elliptical flagellum of the male of other species of Baalrog, it is placed in the genus based on the phylogenetic analyses (fig. 6). Discovery of the female and/or closely related new species may confirm or refute the placement of this peculiar species, which occurs in sympatry with its congener, $B$. firstmani, comb. nov.

Baalrog firstmani (Rowland, 1973), comb. nov.

Schizomus firstmani Rowland, 1973a: 6, 7, 15-19, figs. $14-16$; 1973c: 136; 1975b: 34, 167, 168, 232, 234, 235-240, 243, 246-249, 252, 253, map 4, figs. 217, 219, 220, 226-227; Dumitresco, 1977: 157; Rowland and Reddell, 1977: 80, 84, 98, 99, fig. 2; 1979a: 163; 1980: 1, 23-30, figs. $63,65,67,68,74,75$; Reddell, 1981: 16, 42, 45, 126, 128, 320, 321, 324, fig. 23; Palacios-Vargas, 1983: 43 (part); Cokendolpher and Reddell, 1984b: 242; Reddell and Cokendolpher, 1986: 34, 36; 1995: 5, 106.

Stenochrus firstmani: Reddell and Cokendolpher, 1991: 18; 1995: 5, 12, 18, 101, 103, 106; Vázquez-Rojas, 1995: 33; 1996: 65; Harvey, 2003: 123; Armas and Cruz-López, 2009: 20; Palacios-Vargas and Reddell, 2013: 52; Palacios-Vargas et al., 2015: 32; Monjaraz-Ruedas and Francke, 2018: 190, 207.

Type Material: Schizomus firstmani: MEXICO: Veracruz: Municipio de Atoyac: Grutas de Atoyac, $2 \mathrm{~km}$ E of Atoyac, 24.xii.1971, D. McKenzie, holotype ô (AMNH), 6.viii.1969, S. and J. Peck, 2 ㅇ, 3 imm. paratypes (AMNH).

Additional Material Examined: MEXICO: Veracruz: Municipio de Atoyac: Grutas de Atoyac, C. Bolivar, and Pieltain, 2 을 (AMNH), 13.xi.1941, C. Bolivar, Pieltain, and F. Bonet, 1 q $1 \mathrm{imm}$. (AMNH); Grutas de Atoyac, $18^{\circ} 54^{\prime} 41^{\prime \prime} \mathrm{N}$ 


\section{TABLE 2}

Diagnostic morphological characters among four North American genera of short-tailed whipscorpions (Schizomida: Hubbardiidae Cook, 1899): Ambulantactus, gen. nov.; Baalrog, gen. nov.; Harveyus, gen. nov.; Heteroschizomus Rowland, 1973, stat. rev.

\begin{tabular}{|c|c|c|c|c|}
\hline & Ambulantactus & Baalrog & Harveyus & Heteroschizomus \\
\hline 1. Propeltidial setae & three & three & two & four \\
\hline 2. Opisthosomal enlargement & absent & absent & absent & present \\
\hline 3. Cheliceral movable finger & smooth & smooth & smooth & lamella \\
\hline 4. Macrosetal group G3 & G3-3 anterior & G3-4 posterior & G3-3 anterior & G3-3 anterior \\
\hline 5. Pedipalps sexual dimorphism & absent & absent & present & absent \\
\hline 6. Pedipalp apical process & acute & absent & bump & acute \\
\hline 7. Pedipalp macroseta & $\begin{array}{l}\text { setiform, } \\
\text { acuminate }\end{array}$ & $\begin{array}{l}\text { setiform, } \\
\text { acuminate }\end{array}$ & $\begin{array}{l}\text { setiform, } \\
\text { acuminate }\end{array}$ & $\begin{array}{l}\text { setiform, } \\
\text { acuminate }\end{array}$ \\
\hline 8. Tibia formula & $4-3-5$ & $3-3-5$ & $3-3-4$ & $3-3-4$ \\
\hline 9. Flagellum shape $(\hat{0})$ & deltoid & bulb & subrhomboidal & spatulate \\
\hline 10. Flagellum dorsal surface relief $(\widehat{\delta})$ & $\begin{array}{l}\text { pair of posterior } \\
\text { fused depressions }\end{array}$ & absent & $\begin{array}{l}\text { pair of } \\
\text { shallow pits }\end{array}$ & $\begin{array}{l}\text { pair of median pits } \\
\text { or central depression }\end{array}$ \\
\hline 11. Spermatheca lateral lobes length & $\begin{array}{l}\text { lateral reduced } \\
(3 / 4)\end{array}$ & $\begin{array}{l}\text { lateral reduced } \\
(1 / 4,1 / 3)\end{array}$ & $\begin{array}{l}\text { lateral reduced } \\
(3 / 4)\end{array}$ & equal to median pair \\
\hline 12. Spermatheca lateral apex orientation & upright & outward & outward & upright \\
\hline 13. Spermatheca median apex orientation & upright & outward & outward & upright \\
\hline 14. Spermatheca median lobes shape & straight & curved at tip & parenthesis shaped & straight \\
\hline 15. Spermatheca bulbs & absent & absent & small & absent \\
\hline 16. Spermatheca sclerotization & absent & absent & absent & absent \\
\hline 17. Spermatheca lobes base position & $\begin{array}{l}\text { median } \\
\text { posterior }\end{array}$ & $\begin{array}{l}\text { median } \\
\text { anterior }\end{array}$ & same level & variable \\
\hline 18. Spermatheca chitinized arch shape & $\begin{array}{l}\text { inverse } \\
\text { arch shaped }\end{array}$ & hastate & V-or U-shaped & mug shaped \\
\hline
\end{tabular}

$96^{\circ} 46^{\prime} 42^{\prime \prime} \mathrm{W}, 500$ m, 6.xii.1981, V. Granados, 1 우 (CNAN Sz44), 19.ix.2015, J. Arreguin, D. Barrales, O. Francke, D. Guerrero, and R. Monjaraz, 1 o , 3 ㅇ (CNAN Sz170), 16.i.2017, D. Barrales, G. Contreras, and R. Monjaraz, 20,3 (CNAN DNA-Sz231), 1 오 (AMCC [LP 14531]).

\section{Baalrog magico (Monjaraz-Ruedas and Francke, 2018), comb. nov.}

Stenochrus magico Monjaraz-Ruedas and Francke, 2018: 190, 207-211, figs. 57-66.

Type Material: Stenochrus magico: MEXICO: Oaxaca: Municipio de Huautla de Jimé- nez: Millipede Cave, Río Iglesia Dolina, $18^{\circ} 07^{\prime} 03^{\prime \prime} \mathrm{N} 96^{\circ} 47^{\prime} 59^{\prime \prime} \mathrm{W}, 1610 \mathrm{~m}$, 26.iii.1981, A. Grubbs and S. Zeman, holotype ơ (CNAN T1163); Cueva Li-Nita, $18^{\circ} 08^{\prime} 51^{\prime \prime} \mathrm{N} 96^{\circ} 47^{\prime} 54^{\prime \prime} \mathrm{W}$, 1919 m, 12.iv.2014, G. Contreras, J. Cruz, S. Davlantes, O. Francke, and J. Mendoza, paratype $\delta$ (CNAN T1164); Cueva, $100 \mathrm{~m} \mathrm{~S}$ of Puente de Fierro, 1809'03"N 96 51'12"W, 1197 m, 11.ix.2010, D. Barrales, J. Cruz, O. Francke, and A. Valdez, paratype $q$ (CNAN T1165). Municipio de San Miguel Cuahutepec: Cueva Cangrejo, 12.iv.2015, G. Contreras, O. Francke, J. Mendoza, M. Minton, and R. Monjaraz, $18^{\circ} 06^{\prime} 26^{\prime \prime} \mathrm{N} 96^{\circ} 47^{\prime} 54^{\prime \prime} \mathrm{W}, 1540 \mathrm{~m}$, paratype 우 (CNAN T1166). 


\section{TABLE 3}

Diagnostic morphological characters among four North American genera of short-tailed whipscorpions (Schizomida: Hubbardiidae Cook, 1899): Mayazomus Cokendolpher and Reddell, 1995; Nahual, gen. nov.; Olmecazomus, nom. nov.; Pacal Reddell and Cokendolpher, 1995

\begin{tabular}{|c|c|c|c|c|}
\hline & Mayazomus & Nahual & Olmecazomus & Pacal \\
\hline 1. Propeltidial setae & two & three & two & three \\
\hline 2. Opisthosomal enlargement & absent & absent & absent & absent \\
\hline 3. Cheliceral movable finger & smooth & $\begin{array}{l}\text { lamella/ } \\
\text { one tooth }\end{array}$ & smooth & lamella \\
\hline 4. Macrosetal group G3 & G3-3 posterior & G3-3 anterior & G3-2,4 posterior & G3-4 posterior \\
\hline 5. Pedipalps sexual dimorphism & present & absent & absent & absent \\
\hline 6. Pedipalp apical process & acuminate & fan & digitiform & acuminate \\
\hline 7. Pedipalp macroseta & $\begin{array}{l}\text { spiniform } \\
\text { setiferous } \\
\text { tubercle }\end{array}$ & spiniform & $\begin{array}{l}\text { spiniform } \\
\text { setiferous } \\
\text { tubercle }\end{array}$ & $\begin{array}{l}\text { setiform, } \\
\text { acuminate }\end{array}$ \\
\hline 8. Tibia formula & $4-3-4$ & $5-5-6$ & $4-4-4$ & $3-3-4(5)$ \\
\hline 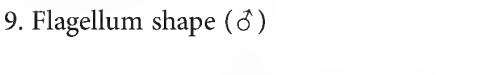 & cordate & elliptical & elliptical & $\begin{array}{l}\text { trilobate/ } \\
\text { rhomboidal }\end{array}$ \\
\hline 10. Flagellum dorsal surface relief $\left({ }^{\star}\right)$ & $\begin{array}{l}\text { pair of } \\
\text { submedian } \\
\text { depressions }\end{array}$ & $\begin{array}{l}\text { pair of } \\
\text { submedian pits/ } \\
\text { slumps }\end{array}$ & $\begin{array}{l}\text { pair of } \\
\text { submedian } \\
\text { depressions }\end{array}$ & $\begin{array}{l}\text { pair of median pits } \\
\text { with pair } \\
\text { of swellings }\end{array}$ \\
\hline 11. Spermatheca lateral lobes length & $\begin{array}{l}\text { lateral reduced } \\
(3 / 4)\end{array}$ & $\begin{array}{l}\text { equal to } \\
\text { median pair }\end{array}$ & $\begin{array}{l}\text { lateral reduced } \\
(1 / 4)\end{array}$ & $\begin{array}{l}\text { absent/ } \\
\text { reduced }(1 / 4)\end{array}$ \\
\hline 12. Spermatheca lateral apex orientation & upright & outward & upright & upright \\
\hline 13. Spermatheca median apex orientation & outward & upright & upright & upright \\
\hline 14. Spermatheca median lobes shape & J-shaped & straight & $\begin{array}{l}\text { parenthesis } \\
\text { shaped }\end{array}$ & straight \\
\hline 15. Spermatheca bulbs & absent & absent & absent & present \\
\hline 16. Spermatheca sclerotization & present & present & present & absent \\
\hline 17. Spermatheca lobes base position & same level & median posterior & same level & same level \\
\hline 18. Spermatheca chitinized arch shape & U-shaped & arrow shaped & V-shaped & inverse arc shaped \\
\hline
\end{tabular}

Additional Material Examined: MEXICO: Oaxaca: Municipio de Plan Carlota: Church Cave, $18^{\circ} 07^{\prime} 58^{\prime \prime} \mathrm{N} 96^{\circ} 46^{\prime} 35^{\prime \prime} \mathrm{W}, 1500 \mathrm{~m}$, 1.iv.2016, D. Barrales, G. Contreras, J. Cruz, J. Mendoza, and R. Monjaraz, 2 imm. (AMCC [LP 14516]).

Baalrog sbordonii (Brignoli, 1973), comb. nov.

Schizomus sbordonii Brignoli, 1973: 7-9, fig. 4; Rowland, 1973c: 135, 136; Brignoli, 1974:
143, 146-149, 151, figs. 1e, 2c-d; Rowland, 1975b: 34, 189, 234, 236, 239; Rowland and Reddell, 1977: 80, 86, 89, 98, fig. 3; 1979a: 163; 1980: 24, 27, 29; Reddell, 1981: 45, 126, 127, fig. 22; Palacios-Vargas, 1983: 43 (part); Cokendolpher and Reddell, 1984b: 241-243, figs. 1-4; Reddell and Cokendolpher, 1984: 5; 1986: 36; 1995: 6, 115.

Schizomus cf. sbordonii: Rowland, 1975b: 167, $168,232,238-240,248,249,252,253$, map 
TABLE 4

Diagnostic morphological characters among four North American genera of short-tailed whipscorpions (Schizomida: Hubbardiidae Cook, 1899): Schizophyxia, gen. nov.; Sotanostenochrus Reddell and Cokendolpher, 1991; Stenochrus Chamberlin, 1922; Troglostenochrus, gen. nov.

\begin{tabular}{|c|c|c|c|c|}
\hline & Schizophyxia & Sotanostenochrus & Stenochrus & Troglostenochrus \\
\hline 1. Propeltidial setae & three & three & two & two \\
\hline 2. Opisthosomal enlargement & absent & absent & absent & absent \\
\hline 3. Cheliceral movable finger & smooth & smooth & smooth & sawed \\
\hline 4. Macrosetal group G3 & G3-3 anterior & G3-4 posterior & G3-4 posterior & G3-3 anterior \\
\hline 5. Pedipalps sexual dimorphism & absent & present & present & absent \\
\hline 6. Pedipalp apical process & acute & bump & absent & fan \\
\hline 7. Pedipalp macroseta & $\begin{array}{l}\text { setiform, } \\
\text { acuminate }\end{array}$ & $\begin{array}{l}\text { setiform, } \\
\text { acuminate }\end{array}$ & $\begin{array}{l}\text { setiform, } \\
\text { acuminate }\end{array}$ & spiniform \\
\hline 8. Tibia formula & $3-3-4$ & $3-3-5$ & $3-3-4$ & $3-3-4$ \\
\hline 9. Flagellum shape $(\hat{o})$ & spear-shaped & shovel & cordate/elliptical & trilobate \\
\hline $\begin{array}{l}\text { 10. Flagellum dorsal surface } \\
\text { relief }(\hat{\delta})\end{array}$ & $\begin{array}{l}\text { pair of } \\
\text { submedian } \\
\text { depressions }\end{array}$ & $\begin{array}{l}\text { single central depres- } \\
\text { sion with } \\
\text { pair of swellings }\end{array}$ & $\begin{array}{l}\text { pair of pits } \\
\text { associated with } \\
\text { central depression }\end{array}$ & $\begin{array}{l}\text { two submedian } \\
\text { projections }\end{array}$ \\
\hline $\begin{array}{l}\text { 11. Spermatheca lateral lobes } \\
\text { length }\end{array}$ & $\begin{array}{l}\text { lateral reduced } \\
(3 / 4)\end{array}$ & subequal & $\begin{array}{l}\text { lateral reduced } \\
(1 / 3)\end{array}$ & $\begin{array}{l}\text { lateral reduced } \\
(3 / 4)\end{array}$ \\
\hline $\begin{array}{l}\text { 12. Spermatheca lateral apex } \\
\text { orientation }\end{array}$ & upright & upright & outward & outward \\
\hline $\begin{array}{l}\text { 13. Spermatheca median apex } \\
\text { orientation }\end{array}$ & outward & upright & outward & upright \\
\hline $\begin{array}{l}\text { 14. Spermatheca median } \\
\text { lobes shape }\end{array}$ & $\begin{array}{l}\text { straight/ } \\
\text { slightly curved }\end{array}$ & hand shaped & $\begin{array}{l}\text { parenthesis/ } \\
\text { J-shaped }\end{array}$ & $\begin{array}{l}\text { J-shaped/ } \\
\text { straight }\end{array}$ \\
\hline 15. Spermatheca bulbs & absent & absent & absent & absent \\
\hline 16. Spermatheca sclerotization & absent & absent & present & absent \\
\hline $\begin{array}{l}\text { 17. Spermatheca lobes base } \\
\text { position }\end{array}$ & same level & same level & median posterior & median anterior \\
\hline $\begin{array}{l}\text { 18. Spermatheca chitinized arch } \\
\text { shape }\end{array}$ & U-shaped & V-shaped & bowl shaped & hastate \\
\hline
\end{tabular}

4, fig. 225; Rowland and Reddell, 1980: 1, 23-25, 27-30, figs. 63, 73.

Stenochrus sbordonii: Reddell and Cokendolpher, 1991:18; 1995: 6, 12, 18, 101, 103, 115;

Vázquez Rojas, 1995: 34; 1996: 65; Ruíz and Coronado, 2002: 62, 113; Harvey, 2003: 126;

Palacios-Vargas and Reddell, 2013: 52;

Moreno-González et al., 2014: 21; PalaciosVargas et al., 2015: 32; Clouse et al., 2017: 5,
11, figs. 2-4; Wheeler et al., 2017: 582, fig. 2; Monjaraz-Ruedas and Francke, 2018: 190.

Remarks: Baalrog sbordonii, comb. nov., is assigned to Baalrog, gen. nov., with reservation, based on the reduced size of the lateral lobes, as well as the slightly curved median lobes of the female spermathecae. Despite repeated searches at the type locality (Cueva de Ojo de Agua Grande, Municipio de Paraje Nuevo, Veracruz, 


\section{TABLE 5}

Measurements (mm) of the short-tailed whipscorpions, Ambulantactus aquismon, sp. nov., and Ambulantactus montielae, sp. nov. (Schizomida: Hubbardiidae Cook, 1899) Material deposited in the National Collection of Arachnida (CNAN) at the National Autonomous University of Mexico.

\begin{tabular}{|c|c|c|c|c|c|}
\hline \multirow[b]{2}{*}{ Sex } & & \multirow{2}{*}{$\frac{\text { A. aquismon }}{\delta}$} & \multicolumn{3}{|c|}{ A. montielae } \\
\hline & & & $\hat{\sigma}$ & & q \\
\hline Collection & & CNAN & CNAN & & \\
\hline Number & & T1294 & T1291 & T1293 & T1292 \\
\hline Total length & & 3.6 & 4.4 & 4.7 & 4.9 \\
\hline \multirow[t]{2}{*}{ Propeltidium } & Length & 1.2 & 1.4 & 1.5 & 1.3 \\
\hline & Width & 0.6 & 0.7 & 0.8 & 0.8 \\
\hline \multirow[t]{3}{*}{ Flagellum } & Length & 0.4 & 0.5 & 0.5 & 0.3 \\
\hline & Width & 0.2 & 0.3 & 0.3 & 0.1 \\
\hline & Height & 0.1 & 0.2 & 0.2 & 0.1 \\
\hline \multirow[t]{6}{*}{ Pedipalp } & Trochanter length & 0.4 & 0.5 & 0.6 & 0.4 \\
\hline & Femur length & 0.5 & 0.5 & 0.7 & 0.5 \\
\hline & Patella length & 0.5 & 0.5 & 0.7 & 0.4 \\
\hline & Tibia length & 0.4 & 0.5 & 0.6 & 0.5 \\
\hline & Tarsus length & 0.2 & 0.2 & 0.2 & 0.2 \\
\hline & Total length & 2.0 & 2.3 & 2.9 & 2.0 \\
\hline \multirow[t]{8}{*}{ Leg I } & Coxa length & 0.6 & 0.8 & 1.0 & 0.6 \\
\hline & Trochanter length & 0.4 & 0.5 & 0.7 & 0.4 \\
\hline & Femur length & 1.3 & 1.5 & 2.0 & 1.2 \\
\hline & Patella length & 1.7 & 1.9 & 2.8 & 1.4 \\
\hline & Tibia length & 1.3 & 1.4 & 2.0 & 1.1 \\
\hline & Basitarsus length & 0.4 & 0.5 & 0.6 & 0.3 \\
\hline & Telotarsus length & 0.3 & 0.6 & 0.8 & 0.6 \\
\hline & Total length & 6.0 & 7.2 & 9.8 & 5.5 \\
\hline \multirow[t]{7}{*}{ Leg IV } & Trochanter length & - & 0.4 & 0.5 & - \\
\hline & Femur length & - & 1.3 & 1.8 & - \\
\hline & Patella length & - & 0.6 & 0.8 & - \\
\hline & Tibia length & - & 1.0 & 1.4 & - \\
\hline & Basitarsus length & - & 0.8 & 1.2 & - \\
\hline & Telotarsus length & - & 0.6 & 0.7 & - \\
\hline & Total length & - & 4.7 & 6.5 & - \\
\hline
\end{tabular}


Mexico), the male of this species remains unknown.

Material Examined: MEXICO: Veracruz: Municipio de de Paraje Nuevo: Ojo de Agua de Paraje Nuevo (Ojo de Agua Grande), $18^{\circ} 55^{\prime} 35^{\prime \prime} \mathrm{N}$ $96^{\circ} 52^{\prime} 33^{\prime \prime} \mathrm{W}, 22 . i x .2004$, O. Francke A. Gluesenkamp, E. González, C. Savvas, and P. Sprouse, 2 ㅇ (AMNH), 1855'32"N 96 $52^{\prime} 58^{\prime \prime} \mathrm{W}, 601 \mathrm{~m}$, 20.ix.2015, J. Arreguin, D. Barrales, O. Francke, D. Guerrero, and R. Monjaraz. Municipio de Tepetlaxco: Cueva del Cabrito, $19^{\circ} 02^{\prime} 24^{\prime \prime} \mathrm{N}$ 96²49'52"W, 1644 m, 19.ix.2015, O. Francke, D. Barrales, R. Monjaraz, D. Guerrero, and J. Arreguin, 3 imm. (AMCC [LP 14511]). Municipio Tezonapa: Presidio, $18^{\circ} 40^{\prime} 30^{\prime \prime} \mathrm{N} 96^{\circ} 47^{\prime} 0.2^{\prime \prime} \mathrm{W}$, 351 m, 21.ix.2016, D. Barrales, A. Cruz, J. Mendoza, and R. Monjaraz, 6 ㅇ (AMCC [LP 14542]).

\section{Baalrog yacato, sp. nov.}

Schizomus sbordonii male: Cokendolpher and Reddell 1984a: 5, figs. 1-4; 1984b: 241-243; Reddell and Cokendolpher, 1986: 36 [misidentification].

Stenochrus sbordonii male: Reddell and Cokendolpher, 1991: 18; 1995: 6, 12, 18, 101, 103, 115. Monjaraz-Ruedas and Francke, 2018: 190 [misidentification].

Type Material: MEXICO: Veracruz: Municipio de Atoyac: Grutas de Atoyac, $18^{\circ} 55^{\prime} 17^{\prime \prime} \mathrm{N}$ $96^{\circ} 45^{\prime} 55^{\prime \prime} \mathrm{W}, 22.1 x .2004$, A. Gluesenkamp, C. Savvas, P. Sprouse, E. González, and O. Francke, holotype ô (AMCC [LP 3756]).

DiAGNosis: Baalrog yacato, sp. nov., resembles other species of the genus in possessing robust pedipalps with spiniform setae but may be distinguished from them by the fan-shaped apical process on the pedipalp trochanter of the male, and the ovate pygidial flagellum, with a single, circular posterodorsal depression, of the male. Baalrog yacato also resembles species of Nahual, gen. nov., in the ovate male pygidial flagellum but may be separated from the latter by the presence of a sin- gle depression, rather than a pair of depressions in the dorsal surface of the flagellum.

Eтymology: The specific epithet is an anagram derived from the type locality and used as a noun in apposition.

REMARKS: Based on the morphology of the male pygidial flagellum, as well as DNA sequence data, the male holotype of $B$. yacato, sp. nov., is not conspecific with $B$. sbordonii, comb. nov., as mistakenly assumed by previous authors (Cokendolpher and Reddell, 1984a, 1984b; Reddell and Cokendolpher, 1986, 1991; Monjaraz-Ruedas and Francke, 2018). The type locality of B. sbordonii, Cueva de Ojo de Agua, is a considerable distance from the type locality of B. yacato, Grutas de Atoyac, and part of a different cave system. Further collecting is needed to obtain the male of $B$. sbordonii and the female of $B$. yacato.

Additional Material Examined: MEXICO: Veracruz: Cueva de Atoyac, 2 km E Atoyac, C. Bolívar Pieltain, 1 ô (AMNH).

Harveyus, gen. nov.

Figures 3,6, 7D, 8C, D, 11B, 13D, 17G-I, 18A, B, 19A-C; tables 1,2

Stenochrus (part): Reddell and Cokendolpher, 1991: 1, 3.

Schizomus mexicanus group (part): Rowland 1975b: 37, 39, 164, 165, 167, 168, 173, 185, $209,214,216,218,220,222,224,228,255$, $280,301,303,320,321,348-350,365,366$, $368,369,376,387,390,391-393,395$; Rowland and Reddell, 1979a: 165, 171; 1979b: 90, 107; 1980: 1-8, 10, 11, 15-20; Reddell, 1981: 126; Rowland and Reddell, 1981: 19, 20, 41; Reddell and Cokendolpher, 1986: 32, 34; Camilo and Cokendolpher, 1988: 53, 57; Armas, 1989a: 7; Armas and Abud-Antun, 1990: 14, 18; Reddell and Cokendolpher, 1991: 1, 3; 1995: 82, 99, 101-104; Krüger and Dunlop, 2010: 52; Monjaraz-Ruedas 
and Francke, 2015: 452; 2016: 781-783, 804; 2018: 189, 212.

Type Species: Schizomus mexicanus Rowland, 1971 [= Harveyus mexicanus (Rowland, 1971), comb. nov.], type species, here designated.

Diagnosis: Harveyus, gen. nov., may be separated from other hubbardiid genera by the following combination of characters. Cheliceral movable finger without accessory teeth or lamella; single guard tooth at end of serrula; setal group G3 with G3-3 setae situated anteriorly (fig. 13D). Propeltidium anterior process with two anterior setae (one posterior to the other) and two pairs of dorsosubmedian setae (fig. 11B); corneate eyes absent. Metapeltidium entire. Tegument without clavate setae. Pedipalps heteromorphic, elongated (e.g., H. mexicanus, comb. nov.) or homeomorphic (e.g., in Harveyus contrerasi, sp. nov.); trochanter with mesal spur, with small rounded or bumpshaped apical process (fig. 7D); femur $F v_{1}$ and $F v_{2}$ setae acuminate, $F v r_{1-3}$ setae present; patella with four acuminate $P e$ setae and four feathered Pm setae; tibial setal formula 3-3-4 (Ter-TmrTir) (fig. 14D). Leg IV femur anterodorsal margin produced at ca. $90^{\circ}$ angle. Opisthosomal tergite II with one pair of setae $(\mathrm{Dm})$. Opisthosomal segments IX-XII not elongated; XII ( $ぇ)$ without posterodorsal process. Pygidial flagellum ( $\widehat{O})$ dorsoventrally compressed, subrhomboidal, acute posteriorly (except in $H$. mulaiki, comb. nov., which is bulb shaped), with pair of shallow, dorsosubmedian pits (fig. 19A-C); flagellum ( 9 ) with two annuli (fig. 17G-I). Spermathecae ( $q$ ) with two pairs of lobes of similar width; lateral lobes shorter than (ca. 3/4 the length) median lobes, with the apex directed laterally; median lobes parenthesis shaped, with small apical bulbs; lobes unsclerotized apically (fig. 8C, D); median and lateral lobe bases aligned (fig. 10A), with duct openings along entire length; chitinized arch V- or arch shaped, without anterior branch, lateral tips diffuse; gonopod long and slender.
Comparisons: Species of Harveyus, gen. nov., resemble species of Stenochrus in the number of dorsal setae on the propeltidium, the pedipalp setae formula, and the general shape of the female spermathecae. However, the male pygidial flagellum is bulbous or subrhomboidal with the posterior part acuminate in Harveyus but cordate or elliptical in Stenochrus; the apical process on the pedipalp trochanter is present and bump shaped in Harveyus, but absent in Stenochrus; and the lateral lobes of the female spermathecae are ca. $3 / 4$ the length of the median lobes, unsclerotized apically and with small apical bulbs in Harveyus, but ca. 1/3 the length of the median lobes, sclerotized apically and without apical bulbs in Stenochrus.

Eтymology: This genus is named after Mark S. Harvey of the Western Australian Museum, in recognition of his many contributions to the world schizomid fauna. It is masculine in gender.

InCLUded SPECIES: Harveyus contrerasi, sp. nov.; Harveyus mexicanus (Rowland, 1971a), comb. nov.; Harveyus mulaiki (Gertsch, 1940), comb. nov.; and Harveyus reddelli (Rowland, 1971a), comb. nov.

Distribution: Harveyus, gen. nov., is distributed from Ciudad Valles in the state of San Luis Potosí, Mexico, to Edinburg and Rio Grande City in Texas, United States. Most records of this genus are from caves in the Mexican states of San Luis Potosí and Tamaulipas.

Natural History: Species of Harveyus, gen. nov., are mostly cavernicolous. However, $H$. contrerasi, sp. nov., and $H$. mulaiki, comb. nov., are epigean.

Remarks: The placement of $H$. reddelli, comb. nov., is problematic because, although the male morphology is consistent with the diagnosis of Harveyus, gen. nov., the shape of the female spermathecae more closely resembles the species of Schizophyxia, gen. nov. DNA sequence data are needed to test the generic placement of this species. 
Harveyus contrerasi, sp. nov.

Figures 3, 6, 7D, 8C, 11B, 13D, 17G-I, 18A, B, 19A-C; tables 1,6

Type Material: MEXICO: San Luis Potosí: Municipio de Xilitla: Tlamaya, $1 \mathrm{~km} \mathrm{E}$, $21^{\circ} 25^{\prime} 10^{\prime \prime} \mathrm{N} 99^{\circ} 00^{\prime} 11^{\prime \prime} \mathrm{W}, 777 \mathrm{~m}, 10 . v \cdot 2012, \mathrm{G}$. Contreras, J. Cruz, J. Mendoza, and R. Monjaraz, holotype ơ (CNAN T1276), paratype ô (CNAN T1277); Camino del Jobo a las pozas, $21^{\circ} 24^{\prime} 09^{\prime \prime} \mathrm{N}$ $98^{\circ} 58^{\prime} 54^{\prime \prime} \mathrm{W}, 610 \mathrm{~m}, 25 . x .2013$, J. Cruz, O. Francke, A. Guzman, and C. Santibañez, paratype $\delta$, paratype $q$ (CNAN T1278); El Nacimiento, between Xilitla and Huehuetlan, $21^{\circ} 27^{\prime} 33^{\prime \prime} \mathrm{N} 98^{\circ} 58^{\prime} 36^{\prime \prime} \mathrm{W}, 120 \mathrm{~m}, 11 . i i .2011, \mathrm{G}$. Contreras, J. Cruz, O. Francke, C. Santibañez, and A. Valdez, paratype $q$ (CNAN T1279).

DiAgnosis: Harveyus contrerasi, sp. nov., may be distinguished from other species of the genus by the male pygidial flagellum, which is subrhomboidal with a pair of separate, shallow pits dorsosubmedially, and the female spermathecae, which exhibit curved median lobes, with small apical bulbs and a wide U-shaped chitinized arch. Harveyus contrerasi is most closely related to Harveyus mexicanus, comb. nov. However, the male pedipalps are heteromorphic, with a prominent mesal spur on the tibia in $H$. mexicanus, but homeomorphic and without tibial spurs in $H$. contrerasi. Although the female spermathecae of the two species are similar in general shape, the median lobes are curved, the apical bulb well developed, and the chitinized arch wide and U-shaped in $H$. contrerasi, whereas the median lobes are very slightly curved, almost linear, the apical bulbs inconspicuous, and the chitinized arch V-shaped in $H$. mexicanus.

Eтymology: This specific epithet is a patronym for Gerardo Contreras, in appreciation of his assistance during multiple schizomid collecting trips as well as his contributions to Mexican arachnology.

Description: The following description is based on the holotype male and paratype female (fig. 18A, B).
Color: Pale brownish.

Prosoma: Propeltidium with two setae on anterior process; two pairs of dorsal setae; ocular spots indistinct, irregular. Metapeltidium 0.38 $\mathrm{mm}$ long, $0.67 \mathrm{~mm}$ wide. Anterior sternum with nine setae, plus two sternophysial setae; posterior sternum with six setae.

Chelicerae: Movable finger serrula with 22 (क) or 24 ( $q$ ) teeth, guard tooth present (fig. 13D). Fixed finger with four $(\$)$ or five $(q)$ smaller teeth between two primary teeth; setal group formula, 3-6-4-2-6-8-1-7 (ठ) or 3-6-4-2-7-10-1-7 ( $q$ ); $\mathrm{G} 1$ with three spatulate setae, covered with small spinose spicules; G2 composed of six feathered setae, subequal, shorter than movable finger; G3 with four setae, subequal, feathered apically and smooth basally; G4 consisting of two small smooth, thick setae; G5A with six setae, subequal, feathered apically and longer than fixed finger; G5B with eight feathered setae, subequal; G6 with one smooth seta, ca. 1/2 the length of movable finger; G7 with seven slender, feathered setae, subequal.

Pedipalps: Pedipalps homeomorphic (fig. 7D); $1.73 \times(\hat{0})$ or $1.59 \times($ ( ) longer than propeltidium. Trochanter with small rounded apical process; prolateral surface with small apical spur. Femur $1.94 \times$ longer than high; retroventral margin with setae $\mathrm{Fe}_{1}, \mathrm{Fe}_{5}, \mathrm{Fev}_{1}$, and $\mathrm{Fev} \mathrm{V}_{2}$ acuminate; prolateral surface with row of three ventral acuminate setae $\left(F m v_{1-3}\right)$ and two dorsal acuminate setae $\left(F m d_{2}, F m d_{3}\right)$. Patella with five acuminate $P e$ setae and four feathered $P m$ setae; without distinctive armature. Tibia setal formula, 3:3:4; Ter setae acuminate, Tmr and Tir setae feathered. Tarsal spurs asymmetric.

Legs: Leg I, basitarsal-telotarsal proportions, 28:4:5:5:5:6:14; IV, femur 4.9× longer than high.

Opisthosoma: Tergite I with two pairs of microsetae anteriorly plus pair of $D m$ setae; II with three pairs of microsetae anteriorly plus pair of Dm setae; III-VII each with one pair of $D m$ setae; VIII with pairs of $D m$ and $D l_{2}$ setae; IX with pairs of $D l_{1}$ and $D l_{2}$ setae and without pair of $D m$ setae. Segments X and XI telescoped, 
slightly elongated, with pairs $D l_{2}, V m_{2}, V l_{1}$, and $V l_{2}$ setae plus single $V m_{1}$ seta; XII with pairs of $D m, D l_{1}, D l_{2}, V m_{1}, V m_{2}, V l_{1}$, and $V l_{2}$ setae, without posterodorsal process. Sternites II-VII each with two irregular rows of setae; genital plate with many scattered microsetae.

Pygidial flagellum: Flagellum ( 0 ) dorsoventrally compressed, subrhomboidal (fig. 19A-C); $2.07 \times$ longer than wide; pair of shallow dorsosubmedian pits present; seta $D m_{1}$ situated over bulb base, $D m_{4}$ situated posteriorly, $D l_{2}$ situated anterior to $\mathrm{Vl}_{1}, \mathrm{Dl}_{3}$ situated posterior to $V l_{2}$; pair of $V m_{2}$ setae present, $V m_{1}$ situated posterior to $V m_{2}$; pair of anterodorsal microsetae between $D m_{1}$ and $D l_{2}$, pair of anterolateral microsetae on flagellar pedicel, two patches of microsetae between $V l_{1}$ and $V l_{2}(m s p)$. Flagellum ( $q$ ) with three flagellomeres (fig. 17G-I); seta $\mathrm{Dl}_{2}$ reduced, aligned with $V l_{1}, D l_{3}$ aligned with $V l_{2}, V m_{2}$ present, reduced, $V m_{1}$ aligned with $V m_{2} ; D l_{1}$ and $D l_{4}$ microsetae present.

Female spermathecae: Two pairs of lobes (fig. 8C); median lobes curved J-shaped with small apical bulb, and duct openings along entire length; lateral lobes linear, shorter than median lobes, wider basally, with few duct openings; median lobe bases aligned with lateral lobe bases. Chitinized arch wide U-shaped; anterior branch absent; lateral tip wide and diffuse. Gonopod slender, cylindrical; length ca. $3 \times$ width.

Distribution: This species is widely distributed in the vicinity of Huichihuayan and Xilitla in the southern part of San Luis Potosí state, Mexico (fig. 3).

Natural History: Although some specimens of $H$. contrerasi, sp. nov., were collected in a glen ca. $30 \mathrm{~m}$ deep, the glen has a wide entrance and multiple light entrances, hence the species is essentially epigean. Other new species may occur in the caves of the Sierra de Xilitla.

Remarks: Harveyus contrerasi, sp. nov., is closely related to $H$. mexicanus, comb. nov., a species restricted to caves in the state of San Luis Potosí. Although differences in the male pygidial flagella of the two species are very subtle, their pedipalps are markedly different. The pedipalp dimorphism (enlargement) that occurs in $H$. mexicanus was not observed among males of $H$. contrerasi.

Additional Material Examined: MEXICO: San Luis Potosí: Municipio de Xilitla: Camino del Jobo a las pozas, $21^{\circ} 24^{\prime} 09^{\prime \prime} \mathrm{N}$ $98^{\circ} 58^{\prime} 54^{\prime \prime} \mathrm{W}, 610 \mathrm{~m}, 25 . x .2013$, J. Cruz, O. Francke, A. Guzman, and C. Santibañez, 1 우 (AMCC [LP 14493]).

\section{Harveyus mexicanus (Rowland, 1971), comb. nov.}

Schizomus mexicanus Rowland, 1971a: 117-119, 124, 125, figs. 1-3, 16 (part, all records except Cueva de los Vampiros); Reddell and Mitchell, 1971a: 145; Brignoli, 1973: 6; Reddell, 1973: 38; Reddell and Elliott, 1973: 183; Rowland, 1973a: 10, 21, 22, figs. 20, 22; 1973b: 200, 201, fig. 1; 1973c: 135, 137; Brignoli, 1974: 143, 146-147, 149, 151, fig. 1(e); Vomero, 1974: 345; Rowland, 1975a: 14, 15, 19, 20; 1975b: 10, 11, $33,166-169,177,179,180-184,211,213-215$, $218,219-221,224,225,228,230,366-369$, 394, 395, map 5, figs. 2 (below), 155, 156, 171, 172, 185-187,207-210, 292; Rowland and Reddell, 1977: 80, 83, 85-87, 96, fig. 3; 1979a: 163 ; 1980: 1, 2, 4, 5, 7, 9, 10, 12-13, 15, 17, 20, 21, figs. 1-3, 18-19, 32-34, 54-57; Reddell, 1981: $36,38,68,126,127,129,130$, fig. 22 ; 1982: 263; Reddell and Cokendolpher, 1986: 32; 1995: 5, 107, 109, 115.

Stenochrus mexicanus: Reddell and Cokendolpher, 1991: 18; 1995: 5, 12, 18, 101, 102, 107, 145, fig. 6; Vázquez-Rojas, 1995: 34; 1996: 65; Armas and Teruel, 1998: 47; Harvey, 2003: 124; Zawierucha et al., 2013: 359; Palacios-Vargas and Reddell, 2013: 52; Palacios-Vargas et al., 2015: 32. Monjaraz-Ruedas and Francke, 2016: 783, 784, 788, 804; Villarreal et al., 2016: 4, 23; Monjaraz-Ruedas and Francke, 2018: 190, 196, 212.

Type MAterial: Schizomus mexicanus: MEXICO: San Luis Potosí: Municipio de Ciudad 
Valles: Sótano de la Tinaja, $10 \mathrm{~km}$ NNE Ciudad Valles, 18.ii.1970, J.A.L. Cooke, holotype $\hat{\delta}, 1$ t 2 q paratypes (AMNH).

Remarks: Multiple records of $H$. mexicanus, comb. nov., from the Sierra El Abra in San Luis Potosí, reported by Rowland and Reddell (1980), may be different species or the complex cave system within the mountain range may have enabled this species to disperse underground and colonize the entire range. More detailed analyses, including multiple populations from this mountain range, should be undertaken to assess whether H. mexicanus is one species or many.

Additional Material Examined: MEXICO: San Luis Potosí: Municipio de Ciudad Valles: Cueva de los Sabinos, 20.i.1944, 1 ô, 2 , 3 imm. (AMNH); Cueva de los Sabinos, $22^{\circ} 05^{\prime} 31^{\prime \prime} \mathrm{N} 98^{\circ} 57^{\prime} 25^{\prime \prime} \mathrm{W}, 3 . i x .2015$, G. Montiel and G. Contreras 1 ( Sótano del Arroyo, $10 \mathrm{~km}$ NE of Ciudad Valles, 1 \&, $1 \mathrm{imm}$. (AMNH); Cueva Grande, $14 \mathrm{~km} \mathrm{SE}$ of Ciudad Valles, 1 ㅇ (AMNH); Sótano de la Tinaja, $10 \mathrm{~km}$ NNE Ciudad Valles, 16.iii.1972, J.A.L. Cooke, 3 o, 2 \&, 5 imm. (AMNH), 11.i. 1980, B. and V. Roth, 1 đ, 1 ㅇ, 1 imm. (AMNH); Sótano de la Tinaja, $22^{\circ} 04^{\prime} 33^{\prime \prime} \mathrm{N} 98^{\circ} 58^{\prime} 40^{\prime \prime} \mathrm{W}$, 2338 m, 19.v.2011, D. Candia, R. Monjaraz, R. Paredes, and A. Reyna, 6 o, 8 \& (CNAN Sz131), $2 \mathrm{imm}$. (AMCC [LP 14500]). Municipio de Taninul: Cueva del Tigre, Hotel Taninul, $21^{\circ} 56^{\prime} 12^{\prime \prime} \mathrm{N}$ $98^{\circ} 53^{\prime} 18^{\prime \prime} \mathrm{W}, 39 \mathrm{~m}, 12 . i i .2011$, G. Contreras, J. Cruz, O. Francke, C. Santibañez, and A. Valdez, 4 ô, 1 ㅇ (CNAN Sz151), 11.v.2012, J. Cruz, J. Mendoza, G. Contreras, and R. Monjaraz, 1 , 1 imm. (AMCC [LP 14537]), 2.ix.2015, G. Contreras, J. Cruz, O. Francke, C. Santibañez, and A. Valdez, 4 ㅇ (CNAN Sz187).

Harveyus mulaiki (Gertsch, 1940), comb. nov.

Schizomus mulaiki Gertsch, 1940: 1, 3-4, figs. 7-10; Takashima, 1951: 102; Rémy, 1961: 407; Rowland, 1971b: 304; 1975a: 32, 166$169,172,173,177,214,215,218,219,228$, $229,366,367,368,369,394$, map 5, figs.
162, 178, 292; Rowland and Reddell, 1976: 3, 20, 21; 1977: 79, 83; 1979a: 162; 1980: 1, 2, 4-10, 15, figs. 1, 8, 25; Coddington et al., 1990: 12, 13; Reddell and Cokendolpher, 1995: 2, 4, 108.

Stenochrus mulaiki: Reddell and Cokendolpher, 1991: 18; Cokendolpher and Reddell, 1992: 72; Reddell and Cokendolpher, 1995: 4, 12, 18, 102, 108; Vázquez-Rojas, 1995: 34; 1996: 65; Ruíz and Coronado, 2002: 67; Harvey, 2003: 124; Zawierucha et al., 2013: 359.

Type Material: Schizomus mulaiki: U.S.A.: Texas: Starr County: Rio Grande City, 21.vi.1939, S. Mulaik, holotype ô (AMNH). Hidalgo County: Edinburg, 2.vi.1935, S. Mulaik, paratype $\hat{o}(\mathrm{AMNH})$.

Natural History: Although $H$. mulaiki inhabits very dry areas in southern Texas, the type specimens were found in a humid microhabitat, under large concrete slabs near the Rio Grande River. This species may aestivate underground in the dry season, as several attempts to collect it were unsuccessful.

Remarks: The discovery of the female of $H$. mulaiki, comb. nov., will permit a detailed description of its spermathecae.

Harveyus reddelli (Rowland, 1971), comb. nov.

Schizomus reddelli Rowland, 1971a: 123, 124, 126, figs. 13-15; Reddell and Mitchell, 1971b: 185; Reddell, 1973: 38; Rowland, 1973a: 21; 1973c: 135; Brignoli, 1974: 147, 149; Rowland, 1975b: 34, 166-169, 177-179, $181,214,215,218-221,228-230,366-369$, 394, map 5, figs. 159, 175, 189, 190, 292; Rowland and Reddell, 1977: 80, 84, 85, fig. 2; 1979a: 163; 1980: 1, 2, 4, 5, 7, 10, 12, 13, 15, 17, figs. 1, 10, 22, 36, 37; Reddell, 1981: 16, 37, 128-130, 321, 324, fig. 23; Reddell and Cokendolpher, 1986: 32.

Schizomus mexicanus Rowland, 1971a: 117, 118, 119, 124, figs. 1-3, 16 [misidentification; part, Cueva de los Vampiros record only]; 


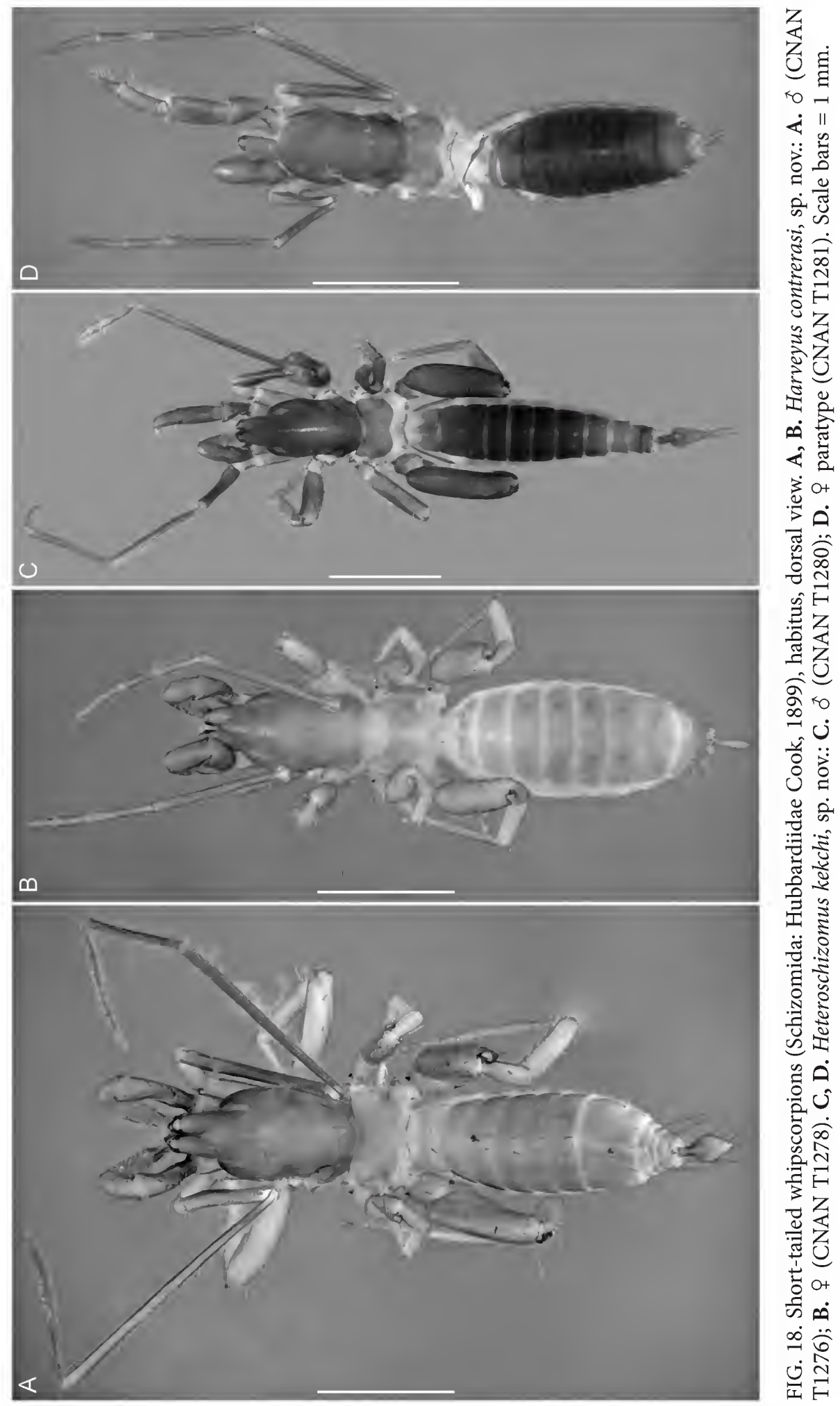


A
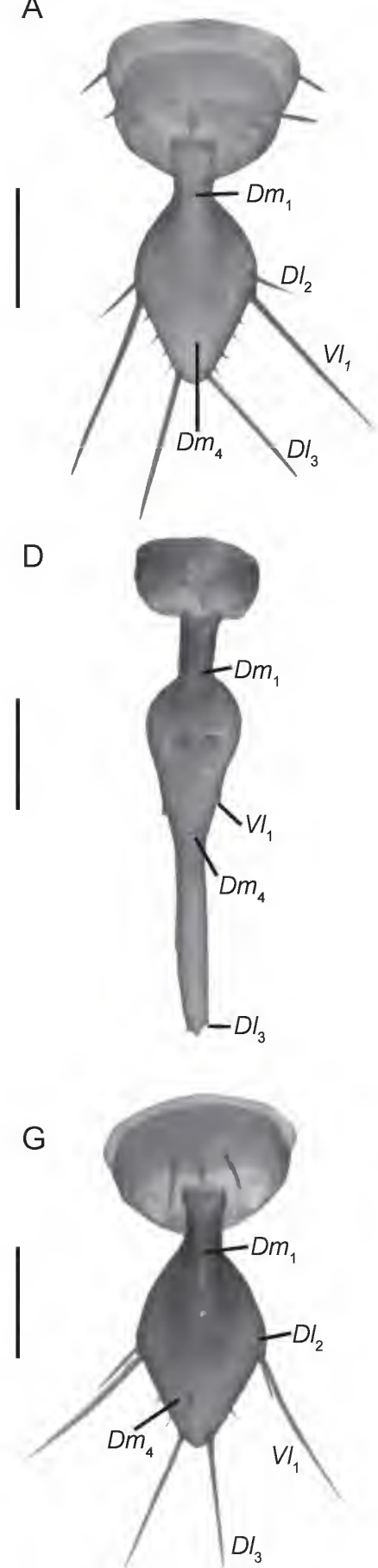
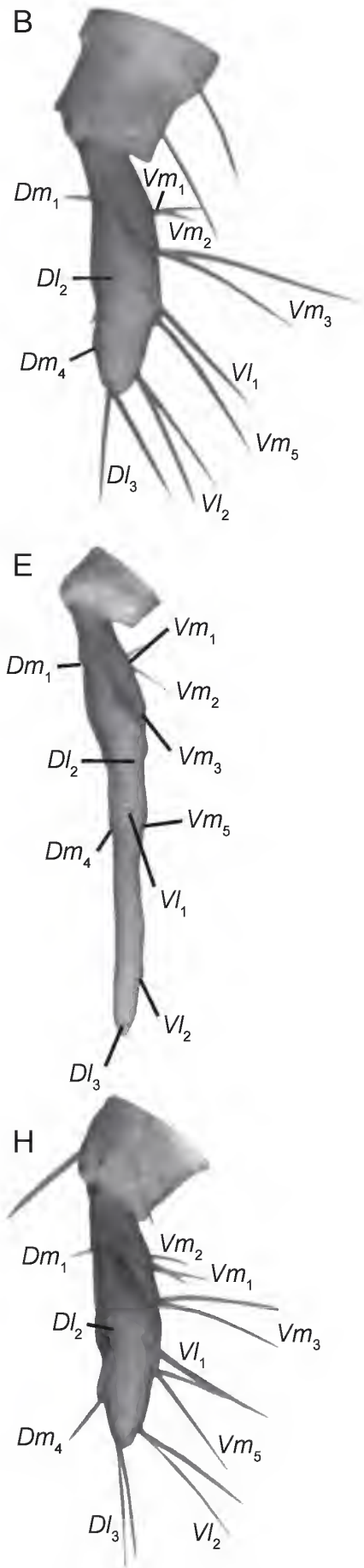

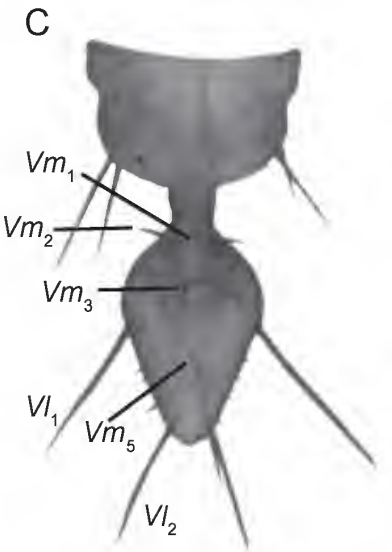

$\mathrm{F}$
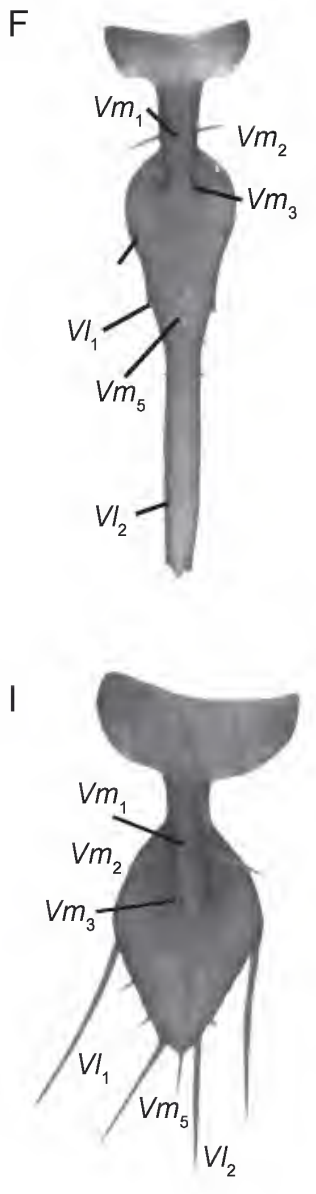

FIG. 19. Short-tailed whipscorpions (Schizomida: Hubbardiidae Cook, 1899), pygidial flagellum, dorsal (A, D, G), lateral (B, E, H) and ventral (C, F, I) views. A-C. Harveyus contrerasi, sp. nov., ơ (CNAN T1276). D-F. Heteroschizomus kekchi, sp. nov., ồ (CNAN T1280). G-I. Nahual bokmai, sp. nov., ô (CNAN T1282). Scale bars $=0.2 \mathrm{~mm}$. 
Reddell and Mitchell, 1971b: 185 [misidentification]; Vomero, 1974: 341 [misidentification]; Reddell and Cokendolpher, 1995: 5, 115.

Schizomus reddeli: Dumitresco, 1977: 157 (lapsus calami).

Stenochrus reddelli: Reddell and Cokendolpher, 1991: 18; 1995: 5, 12, 18, 102, 108, 115; Vázquez-Rojas, 1995: 34; 1996: 65; Ruíz and Coronado, 2002: 67; Harvey, 2003: 125; Zawierucha et al., 2013: 359; Palacios-Vargas and Reddell, 2013: 52; Palacios-Vargas et al., 2015: 32; Monjaraz-Ruedas and Francke, 2018: 212 .

Type Material: Schizomus reddelli: MEXICO: Tamaulipas: Municipio de Ocampo: Cueva de Tres Manantiales, $8 \mathrm{~km}$ NNE Chamal, 27.v.1968, J. Reddell, holotype ơ (AMNH).

REMARKs: Rowland and Reddell's (1980) description of the lateral lobes of the female spermathecae of $H$. reddelli, comb. nov., as "absent" is erroneous. The lateral lobes of this species are filiform, linear, and considerably narrower than the median lobes.

Additional Material Examined: MEXICO: Tamaulipas: Municipio de Gómes Farías: Cueva del Ojital, 23.xi.2005, P. Sprouse, 2 우 (AMCC [LP 14500]), 1 \% (CNAN-Sz25).

Heteroschizomus Rowland, 1973, stat. rev.

Figures 4, 6, 7E, 8E, F, 11C, 13E, 18C, D, 19DF, 21A-F; tables $1,2,7$

Heteroschizomus Rowland, 1973a: 1, 2, 4; 1973b: 197; Rowland and Reddell, 1977: 83; Martín and Oromí, 1984: 266; Reddell and Cokendolpher, 1991: 3, 5, 18.

Stenochrus (part): Reddell and Cokendolpher, 1991: 1, 3.

Schizomus goodnightorum group: Rowland 1975b: 37, 39, 167, 168, 255, 256, 258, 259, $263,265,267,320,321,325,348-350,376$, 390, 397; Rowland and Reddell, 1979a: 165,
171; 1979b: 90; 1980: 3; Reddell, 1981: 126; Rowland and Reddell, 1981: 19-21, 23-25, 27; Reddell and Cokendolpher, 1991: 1, 3; 1995: 101, 102; Villarreal et al., 2008: 64, 67; Moreno-González and Villarreal, 2012: 73; Villarreal and García, 2012: 5; Villarreal et al., 2014: 371; Monjaraz-Ruedas and Francke, 2015: 452; 2016: 781, 783; 2018: $189,212$.

Type Species: Heteroschizomus goodnightorum Rowland, 1973, by original designation.

Diagnosis: Heteroschizomus, stat rev., may be separated from other hubbardiid genera by the following combination of characters. Cheliceral movable finger with lamella (fig. 12C); single guard tooth at end of serrula; setal group G3 with G3-3 setae situated anteriorly (except in Heteroschizomus silvino (Rowland and Reddell, 1977), comb. nov.) (fig. 13E). Propeltidium anterior process with two anterior setae (one posterior to the other) and three or four pairs of dorsosubmedian setae (fig. 11C); corneate eyes absent. Metapeltidium entire. Tegument without clavate setae. Pedipalps homeomorphic; trochanter with small prolateral spur, apical process acute and not projected (fig. $7 \mathrm{E}$ ); femur $F v_{1}$ and $F v_{2}$ setae acuminate, $F v r_{1-3}$ setae present; patella with three acuminate $P e$ setae and three or four feathered $P m$ setae; tibial setal formula 3-3-4 (Ter-Tmr-Tir) (fig. 14D). Leg IV femur anterodorsal margin produced at ca. $90^{\circ}$ angle. Opisthosomal tergite II with one pair of setae $(\mathrm{Dm})$. Opisthosomal seg-

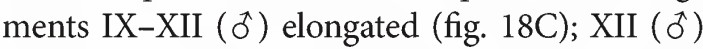
without posterodorsal abdominal process. Pygidial flagellum ( $\hat{\delta}$ ) dorsoventrally flattened, spatulate, with well-defined anterior bulb and posterior constriction in dorsal view, and with pair of anterodorsal pits (except $H$. goodnightorum and Heteroschizomus meambar (Armas and Víquez, 2010), comb. nov., with single median depression) (fig. 19D-F); flagellum ( $q$ ) with two annuli (fig. $21 \mathrm{~A}-\mathrm{F})$. Spermathecae ( $q$ ) with two pairs of lobes, similar in length and width; both pairs of lobes linear with apex directed vertically, unsclerotized (fig. 8E, F); lobes without bulbs; median 
lobe bases variably situated with respect to lateral lobe bases, without duct openings; chitinized arch mug shaped, with wide, sclerotized base (fig. 8E, F); anterior branch curved, unfused medially, with lateral tips wide, curved, and lobed; gonopod wide and short.

Comparisons: Species of Heteroschizomus, stat. rev., resemble species of Piaroa in many aspects of the male morphology and, without females, it is almost impossible to differentiate between them. However, a combination of subtle characters concerning the cheliceral movable finger, the apical process of the pedipalp trochanter, and the number of dorsal setae on the propeltidium enable the males of these genera to be differentiated. The number of dorsal setae on the propeltidium is the most obvious difference between the males of Heteroschizomus and Piaroa. Although the original description of Piaroa mentioned three pairs of dorsal setae (Villarreal et al., 2008), this count included the anterior pair. The correct count for Piaroa is two pairs, as observed in all its component species, except Piaroa youngi Armas and Víquez, 2010, which exhibits three. In contrast, the male of Heteroschizomus bears more than three pairs. Additionally, the cheliceral movable finger of the male bears a small lamella in Heteroschizomus but is smooth or bears teeth or a lamella in Piaroa. The pedipalp trochanter apical process is acute but not projected or forms a small protuberance in the male of Heteroschizomus, but triangular or conical, and projected in the male of Piaroa (except for Piaroa escalerette MorenoGonzalez et al., 2014). Despite the similarity between males of Heteroschizomus and Piaroa, the females of both genera are markedly different. Correct assignment to genus is therefore best achieved with specimens of both sexes. The female pygidial flagellum possesses two annuli in Heteroschizomus, but three annuli in Piaroa; and the female spermathecae possess two pairs of lobes, a mug-shaped chitinized arch, and gonopods in Heteroschizomus, whereas only one pair of lobes and a mask-shaped chitinized arch are present, and gonopods absent in Piaroa.
InCLUded Species: Heteroschizomus goodnightorum Rowland, 1973; Heteroschizomus kekchi, sp. nov.; Heteroschizomus meambar (Armas and Víquez, 2010), comb. nov.; Heteroschizomus orthoplax (Rowland, 1973a), comb. nov.; Heteroschizomus silvino (Rowland and Reddell, 1977), comb. nov.

Distribution: The distribution of Heteroschizomus, stat. rev., extends from the state of Chiapas in southern Mexico southward to Honduras. The southernmost record of the genus is $H$. meambar, comb. nov. There are no records of Heteroschizomus in Costa Rica and Nicaragua, but the northernmost record of Piaroa, i.e., Piaroa bijagua Armas and Víquez, 2009, is from Costa Rica, suggesting the two genera converge and possibly overlap in Nicaragua. More sampling efforts are needed to clarify the distributions of Central American schizomids (fig. 4).

Natural History: Species of Heteroschizomus, stat. rev., are primarily epigean, except for $H$. silvino, comb. nov., a cavernicolous species. Specimens of $H$. goodnightorum have been found near, but not inside, caves in the Yucatán Peninsula. Species of Heteroschizomus exhibit a unique way of walking that is faster than has been observed in other Mexican schizomids, with the elongated opisthosoma flipped over above the prosoma, like ants of the genus Crematogaster Lund, 1831. This has not been reported in other schizomid genera with an elongated opisthosoma, i.e., Colombiazomus Armas and Delgado-Santa, 2012, Hansenochrus, and Piaroa.

REMARKS: The revalidation of Heteroschizomus, stat. rev., is based in part on the discovery of the female of $H$. goodnightorum. Rowland and Reddell (1981) misidentified a female of Stenochrus portoricensis, which occurs in sympatry in the Yucatán Peninsula, as the female of H. goodnightorum. The female spermathecae are similar in $H$. goodnightorum and $H$. silvino, comb. nov., and although the female of $H$. orthoplax, comb. nov., remains unknown, the description of $H$. kekchi, sp. nov., confirms the diagnostic morphology of the spermathecae of 
TABLE 6

Measurements ( $\mathrm{mm}$ ) of the short-tailed whipscorpion, Harveyus contrerasi, sp. nov. (Schizomida: Hubbardiidae Cook, 1899)

Material deposited in the National Collection of Arachnida (CNAN) at the National Autonomous University of Mexico.

\begin{tabular}{|c|c|c|c|c|c|c|c|}
\hline \multirow[b]{2}{*}{ Sex } & & \multicolumn{6}{|c|}{ H. contrerasi } \\
\hline & & 0 & & & & 우 & \\
\hline \multicolumn{2}{|l|}{ Collection } & \multicolumn{4}{|l|}{ CNAN } & \multicolumn{2}{|l|}{ CNAN } \\
\hline Number & & T1276 & T1277 & T1278 & T1279 & T1278 & T1279 \\
\hline Total length & & 3.9 & 3.8 & 3.6 & 3.9 & 3.9 & 3.4 \\
\hline \multirow[t]{2}{*}{ Propeltidium } & Length & 1.3 & 1.4 & 1.4 & 1.3 & 1.2 & 1.6 \\
\hline & Width & 0.7 & 0.8 & 0.7 & 0.7 & 0.7 & 0.9 \\
\hline \multirow[t]{3}{*}{ Flagellum } & Length & 0.5 & 0.5 & 0.5 & 0.5 & 0.3 & - \\
\hline & Width & 0.2 & 0.2 & 0.2 & 0.2 & 0.1 & - \\
\hline & Height & 0.1 & 0.1 & 0.1 & 0.1 & 0.1 & - \\
\hline \multirow[t]{6}{*}{ Pedipalp } & Trochanter length & 0.5 & 0.5 & 0.5 & 0.4 & 0.4 & 0.5 \\
\hline & Femur length & 0.5 & 0.6 & 0.6 & 0.6 & 0.5 & 0.5 \\
\hline & Patella length & 0.5 & 0.6 & 0.6 & 0.6 & 0.5 & 0.5 \\
\hline & Tibia length & 0.5 & 0.5 & 0.6 & 0.5 & 0.4 & 0.5 \\
\hline & Tarsus length & 0.3 & 0.3 & 0.3 & 0.3 & 0.2 & 0.2 \\
\hline & Total length & 2.3 & 2.5 & 2.6 & 2.3 & 1.9 & 2.3 \\
\hline \multirow[t]{8}{*}{ Leg I } & Coxa length & 0.7 & 0.7 & 0.7 & 0.7 & 0.5 & 0.5 \\
\hline & Trochanter length & 0.4 & 0.5 & 0.5 & 0.4 & 0.3 & 0.4 \\
\hline & Femur length & 1.6 & 1.9 & 2.0 & 1.7 & 1.0 & 1.3 \\
\hline & Patella length & 2.0 & 2.5 & 2.7 & 2.1 & 1.1 & 1.5 \\
\hline & Tibia length & 1.4 & 1.8 & 1.9 & 1.5 & 0.8 & 1.1 \\
\hline & Basitarsus length & 0.5 & 0.5 & 0.5 & 0.4 & 0.3 & 0.3 \\
\hline & Telotarsus length & 0.6 & 0.7 & 0.8 & 0.7 & 0.5 & 0.6 \\
\hline & Total length & 7.2 & 8.6 & 9.1 & 7.4 & 4.4 & 5.7 \\
\hline \multirow[t]{7}{*}{ Leg IV } & Trochanter length & 0.4 & 0.5 & 0.5 & 0.4 & 0.3 & 0.4 \\
\hline & Femur length & 2.4 & 1.6 & 1.7 & 1.5 & 1.0 & 1.2 \\
\hline & Patella length & 0.9 & 0.6 & 0.7 & 0.6 & 0.4 & 0.5 \\
\hline & Tibia length & 1.6 & 1.2 & 1.3 & 1.1 & 0.7 & 0.9 \\
\hline & Basitarsus length & 0.9 & 1.0 & 1.0 & 0.9 & 0.6 & 0.8 \\
\hline & Telotarsus length & 0.6 & 0.5 & 0.7 & 0.6 & 0.5 & 0.5 \\
\hline & Total length & 6.7 & 5.4 & 5.8 & 5.0 & 3.6 & 4.3 \\
\hline
\end{tabular}


this genus. In addition, the discovery of a lamella on the movable finger of the chelicera, not reported by Rowland and Reddell (1981), and the constriction of the posterior part of the the male pygidial flagellum, present in all known species of Heteroschizomus (and some species of Piaroa), confirms the monophyly of the genus and justifies its revalidation. The elongated opisthosoma observed in Heteroschizomus appears to have evolved convergently in other schizomid genera, e.g., Hansenochrus, Hubbardia, and Piaroa.

Stenochrus meambar Armas and Víquez, 2010 was assigned to Heteroschizomus based on the presence of a lamella on the cheliceral movable finger and a lanceolate pygidial flagellum, with a medial constriction and a dorsomedian depression, in the male (Armas and Víquez, 2010). The unnamed genus from Honduras described in the same publication (Armas and Víquez, 2010: 18) is probably also a female of Heteroschizomus, because the spermathecae are very similar, with a mug-shaped chitinized arch, and the two pairs of short lobes, similar in length.

\section{Heteroschizomus goodnightorum Rowland, 1973}

Figures 4, 6, 8E, 21A-C; table 7

Heteroschizomus goodnightorum Rowland, 1973a: 2-6; 1973b: 202; 1973c: 136; 1975b: 31;

Rowland and Reddell, 1977: 83; Reddell and Cokendolpher, 1991: 18; 1995: 3, 5, 101, 106.

Schizomus goodnightorum: Rowland 1975a: 34, 167, 168, 194, 257-269, 325, 397; Rowland and Reddell, 1977: 90, 99, 100; 1979a: 163, 164; 1981: 19, 21-27; Reddell and Cokendolpher, 1995: 3, 106.

Stenochrus goodnightorum: Reddell and Cokendolpher, 1991: 18; 1995: 5, 8, 18, 102, 106;

Villarreal et al., 2008: 64; Villarreal and García, 2012: 5; Monjaraz-Ruedas and Francke, 2016: 783, 784, 797, 804; 2018: 190.
Type MATERIAL: MEXICO: Yucatan: Chichén Itzá, vi.1948, C. Goodnight, holotype ô, paratype ô (AMNH).

Supplementary Description: The following description of the female is based on the additional material examined.

Prosoma: Propeltidium with two apical setae; three pairs of dorsal setae.

Chelicerae: Movable finger with very small lamella; serrula with 13 teeth, guard tooth present. Fixed finger with five small teeth between two primary teeth; setal group formula, 3-6-4-2-7-8-1-6.

Pedipalps: Pedipalps homeomorphic; $1.59 \times$ longer than propeltidium. Trochanter with small rounded apical process, not projected; prolateral surface with small apical spur. Femur $1.73 \times$ longer than high; retroventral margin with setae $F e_{1}$, $\mathrm{Fe}_{5}, \mathrm{Fev} v_{1}$, and $\mathrm{Fev}_{2}$ acuminate; prolateral surface with row of three ventral setae $\left(F m v_{1-3}\right)$ and two dorsal setae $\left(F m d_{2}, F m d_{3}\right)$. Patella with three acuminate $P e$ setae and four feathered $P m$ setae; without distinctive armature. Tibia setal formula, 3:3:4; Ter acuminate, Tmr and Tir feathered. Tarsal spurs asymmetric.

Opisthosoma: Segments X-XII not elongated.

Pygidial flagellum: Flagellum ( $q$ ) with three flagellomeres (fig. 21A-C); seta $\mathrm{Dl}_{2}$ reduced, situated posterior to $V l_{1}, D l_{3}$ situated posterior to $V l_{2}, V m_{2}$ present, $V m_{1}$ aligned with $V m_{2} ; D l_{1}$ and $\mathrm{Dl}_{4}$ microsetae present.

Female spermathecae: Two pairs of lobes (fig. $8 \mathrm{E}$ ); median and lateral lobes conical, subequal in length and width; median lobes linear, lateral lobes sublinear, apex slightly curved laterally, unsclerotized apically, with few duct openings; median lobe bases aligned with lateral lobe bases. Chitinized arch mug shaped; anterior branch not sclerotized. Gonopod wide; width ca. $2 \times$ length.

Remarks: Rowland and Reddell (1977) synonymized Heteroschizomus, stat. rev., and transferred $H$. goodnightorum to Schizomus, based on the discovery of other species with an elongated opisthosoma. Reddell and Cokendolpher (1991) transferred Schizomus goodnightorum to Stenochrus based on the morphology of the female 
spermathecae described by Rowland and Reddell (1981). The discovery and correct identification of the female of $H$. goodnightorum confirmed the validity of Heteroschizomus and the correct placement of $H$. goodnightorum and related species, discoveries that were independently supported by the DNA sequence data.

Additional Material Examined: MEXICO: Yucatán: Municipio de Chichén Itzá: Chichen Itzá, vi.1948, C. Goodnight, 1 q (AMNH); Fuera de la Cueva de Kanthon, $20^{\circ} 38^{\prime} 08^{\prime \prime} \mathrm{N} 88^{\circ} 29^{\prime} 42^{\prime \prime} \mathrm{W}, 23 \mathrm{~m}, 2$.viii.2014, J. Mendoza and R. Monjaraz, 4 ô (AMCC [LP 14522]), 2 o, 1 ㅇ (CNAN Sz171). Municipio de Kaua: Fuera de la Cueva de Kaua, $20^{\circ} 37^{\prime} 04^{\prime \prime} \mathrm{N}$ $88^{\circ} 25^{\prime} 26^{\prime \prime} \mathrm{W}, 24$ m, 5.x.2014, G. Contreras and G. Montiel, 1 ô, 2 \& (CNAN Sz163). Quintana Roo: Municipio de Cancun: Km 234 Highway MéridaCancun, $20^{\circ} 53^{\prime} 57^{\prime \prime} \mathrm{N} 87^{\circ} 28^{\prime} 25^{\prime \prime} \mathrm{W}, 19 \mathrm{~m}, 20$. vii.2010, D. Barrales, G. Contreras, J. Cruz, O. Francke, G. Montiel, M. Paradiz, C. Santibañez, and A. Valdez, 1 o (CNAN Sz8).

Heteroschizomus kekchi, sp. nov.

Figures 4, 6, 7E, 8F, 11C, 13E, 18C, D, 19D-F, 21D-F; table 7

Type Material: GUATEMAlA: Izabal Department: Municipio de Livingston: Biotopo Chocon Machacas, Estación USAC, $15^{\circ} 47^{\prime} 15^{\prime \prime} \mathrm{N}$ $88^{\circ} 50^{\prime} 34^{\prime \prime} \mathrm{W}, 15 \mathrm{~m}, 18$.viii.2017, D. Barrales and R. Monjaraz, holotype ô (CNAN T1280), paratype o (AMCC [LP 14559]).

Diagnosis: Heteroschizomus kekchi, sp. nov., may be separated from other species of Heteroschizomus, stat. rev., by the following characters: the pedipalp trochanter of the male bears a small, acute apical process that is not projected; the male pygidial flagellum comprises a slender anterior bulb and a medial constriction with acuminate margins, terminating in a long, slender posterior lobe (fig. 19D-F); and the median and lateral lobes of the female spermathecae are slender and cylindrical, with the lateral lobes longer than the median lobes.
Comparisons: Heteroschizomus kekchi, sp. nov., resembles $H$. silvino, comb. nov., in the shape of the male pygidial flagellum and the female spermathecae. However, the anterior lobe of the flagellum is elliptical and much narrower in $H$. kekchi than in H. silvino, in which the anterior bulb is ovate; the posterior lobe of the flagellum is longer and narrower in $H$. kekchi than in $H$. silvino; and the margin of the medial constriction is acuminate in $H$. kekchi but curved in $H$. silvino. The lateral lobes of the spermathecae are longer than the median lobes and cylindrical in H. kekchi but shorter than the median lobes, wide and teardrop shaped in H. silvino.

Eтyмology: The specific epithet is a noun in apposition, honoring the Kekchi people, who inhabit parts of Alta Verapaz and Izabal in Guatemala.

Description: The following description is based on the holotype male and paratype female (fig. 18C, D).

Color: Olive greenish.

Prosoma: Propeltidium with two setae on anterior process; three pairs of dorsal setae; ocular spots distinct, ovate. Metapeltidium $0.37 \mathrm{~mm}$ long, $0.58 \mathrm{~mm}$ wide. Anterior sternum with nine setae, plus two sternophysial setae; posterior sternum with six setae.

Chelicerae: Movable finger serrula with 17 teeth, guard tooth present, with lamella (fig. $13 \mathrm{E})$. Fixed finger with five smaller teeth between two primary teeth; setal group formula, 3-6-4-27-5-1-5; G1 with three spatulate setae, covered with few small spinose spicules apically; G2 composed of six feathered setae, subequal, and longer than movable finger; G3 with four setae, subequal, feathered apically and smooth basally; G4 consisting of two small setae, smooth, thickened basally, elongated apically; G5A with seven setae, subequal, feathered apically and longer than fixed finger; G5B with five feathered setae, subequal; G6 with one smooth seta, ca. 1/2 the length of movable finger; G7 with five slender, feathered setae, subequal.

Pedipalps: Pedipalps homeomorphic (fig. 7E); $1.66 \times(\delta)$ or $1.69 \times(+)$ longer than propeltid- 
ium. Trochanter with small acute apical process; prolateral surface with small medial spur. Femur $1.8 \times$ longer than high; retroventral margin with setae $\mathrm{Fe}_{1}, \mathrm{Fe}_{5}, \mathrm{Fev} v_{1}$, and $\mathrm{Fev}_{2}$ acuminate; prolateral surface with row of three ventral setae $\left(F m v_{1-3}\right)$ and two dorsal setae $\left(F m d_{2}, F m d_{3}\right)$. Patella with three acuminate $P e$ setae and four feathered $P m$ setae and without distinctive armature. Tibia setal formula, 3:3:4; Ter setae acuminate, Tmr and Tir setae feathered. Tarsal spurs asymmetric.

Legs: Leg I, basitarsal-telotarsal proportions, 23:4:4:3:3:4:8; IV, femur 2.53× longer than high.

Opisthosoma: Tergite I with two pairs of microsetae anteriorly plus pair of $D m$ setae; II with three pairs of microsetae anteriorly plus pair of Dm setae; III-VII each with one pair of $\mathrm{Dm}$ setae; VIII with pairs of $\mathrm{Dm}$ and $D l_{2}$ setae; IX with pairs of $D l_{1}$ and $D l_{2}$ setae and without pair of $D m$ setae. Segments X and XI telescoped, slightly elongated, with pairs of $D l_{2}, V m_{2}, V l_{1}$, and $V l_{2}$ setae plus single $V m_{1}$ seta; XII with pairs of $D m, D l_{1}, D l_{2}, V m_{1}, V m_{2}, V l_{1}$, and $V l_{2}$ setae, without posterodorsal process. Sternites II-VII each with two irregular rows of setae; genital plate with many scattered microsetae.

Pygidial flagellum: Flagellum ( 0 ) dorsoventrally compressed, acuminate (fig. 19D-F); 4.75× longer than wide; pair of anterodorsal pits present; seta $D m_{1}$ situated over bulb base, $D m_{4}$ situated anteriorly, $\mathrm{Dl}_{2}$ situated posterior to $\mathrm{Vl}_{1}, \mathrm{Dl}_{3}$ situated posterior to $V l_{2}$, pair of $V m_{2}$ setae present, $V m_{1}$ situated posterior to $V m_{2}$; pair of anterodorsal microsetae between $D m_{1}$ and $D l_{2}$, pair of anterolateral microsetae on flagellar pedicel, two patches of microsetae between $V l_{1}$ and $V l_{2}$ (msp). Flagellum ( $q$ ) with three flagellomeres (fig. 21D-F); seta $\mathrm{Dl}_{2}$ not reduced, aligned with $V l_{1}, D l_{3}$ situated posterior to $V l_{2}, V m_{2}$ present, reduced, $V m_{1}$ situated posterior to $V m_{2} ; D l_{1}$ and $\mathrm{Dl}_{4}$ microsetae present.

Female spermathecae: Two pairs of lobes (fig. 8F); median and lateral lobes linear, similar in width, with apical duct openings; median lobes shorter than lateral lobes (ca. 3/4); median lobe bases posterior to lateral lobe bases. Chitinized arch mug shaped; anterior branch unfused. Gonopod slender, cylindrical; length ca. $2 \times$ width.

DisTRIBUTION: This species is known only from the type locality in the vicinity of Lake Izabal, in the Izabal Department of Guatemala (fig. 4).

Natural History: The type specimens were collected under rocks and inside rotten logs in a unique area of mangrove swamp and flooded rainforest, which is almost entirely encroached by agriculture.

REMARKs: Despite the geographical proximity of $H$. kekchi, sp. nov., and H. silvino, comb. nov., the two species are markedly different morphologically and $H$. kekchi is epigean, inhabiting tropical rainforest, whereas $H$. silvino appears to be restricted to a cave.

Heteroschizomus orthoplax (Rowland, 1973), comb. nov.

Schizomus orthoplax Rowland, 1973a: 6, 10-13, figs. $8-10$; 1973c: 135; 1975a: 34, 167-168, 257, 258, 260-269, map 4, figs. 236, 240, 244; 1975b: 16; Rowland and Reddell, 1977: 99, 100; 1979a: 163; 1981: 19, 21-27, figs. 1, 3, 7, 11; Reddell and Cokendolpher, 1995: 5, 108.

Schizomus ortoplax: Dumitresco, 1977: 157 (lapsus calami).

Stenochrus orthoplax: Reddell and Cokendolpher, 1991: 18; 1995: 5, 18, 102, 108, 109; Vázquez-Rojas, 1995: 33; 1996: 65; Harvey, 2003: 124; Armas, 2004: 51; Villarreal et al., 2008: 64 .

Type Material: Schizomus orthoplax: MEXICO: Chiapas: Municipio de Tapachula: Finca Cuauhtemoc, 8.v. 1950, C. and M. Goodnight, holotype o (AMNH).

Additional Material Examined: MEXICO: Chiapas: Municipio de Cacahuatan: Cacahuatan, $15^{\circ} 03^{\prime} 37^{\prime \prime} \mathrm{N} 92^{\circ} 08^{\prime} 45^{\prime \prime} \mathrm{W}, 941 \mathrm{~m}, 7$. iii.2017, G. Contreras, J. Cruz, J. Mendoza, and L. Olguín, 2 †, 2 imm. (CNAN DNA-Sz225). 


\section{TABLE 7}

Measurements (mm) of the short-tailed whipscorpions, Heteroschizomus goodnightorum Rowland, 1973, stat. nov., and Heteroschizomus kekchi, sp. nov. (Schizomida: Hubbardiidae Cook, 1899) Material deposited in the National Collection of Arachnida (CNAN) at the National Autonomous University of Mexico and the American Museum of Natural History (AMNH).

\begin{tabular}{|c|c|c|c|c|c|}
\hline \multirow[b]{2}{*}{ Sex } & & \multicolumn{2}{|c|}{ H. goodnightorum } & \multicolumn{2}{|c|}{ H. kekchi } \\
\hline & & q & & $\delta$ & $q$ \\
\hline Collection & & CNAN & CNAN & CNAN & AMNH \\
\hline Number & & Sz0171 & Sz0163 & T1280 & \\
\hline Total length & & 3.6 & 3.0 & 3.8 & 3.1 \\
\hline \multirow[t]{2}{*}{ Propeltidium } & Length & 1.0 & 0.9 & 1.1 & 1.0 \\
\hline & Width & 0.6 & 0.5 & 0.6 & 0.6 \\
\hline \multirow[t]{3}{*}{ Flagellum } & Length & - & 0.2 & 0.9 & 0.3 \\
\hline & Width & - & 0.1 & 0.2 & 0.1 \\
\hline & Height & - & 0.1 & 0.1 & 0.1 \\
\hline \multirow[t]{6}{*}{ Pedipalp } & Trochanter length & 0.3 & 0.3 & 0.3 & 0.4 \\
\hline & Femur length & 0.4 & 0.4 & 0.4 & 0.4 \\
\hline & Patella length & 0.4 & 0.4 & 0.4 & 0.4 \\
\hline & Tibia length & 0.4 & 0.3 & 0.4 & 0.4 \\
\hline & Tarsus length & 0.4 & 0.2 & 0.2 & 0.2 \\
\hline & Total length & 1.9 & 1.5 & 1.8 & 1.8 \\
\hline \multirow[t]{8}{*}{ Leg I } & Coxa length & 0.4 & 0.4 & 0.6 & 0.5 \\
\hline & Trochanter length & 0.3 & 0.3 & 0.3 & 0.3 \\
\hline & Femur length & 0.9 & 0.8 & 1.3 & 1.0 \\
\hline & Patella length & 1.0 & 0.9 & 1.6 & 1.2 \\
\hline & Tibia length & 0.8 & 0.7 & 1.1 & 0.9 \\
\hline & Basitarsus length & 0.3 & 0.2 & 0.4 & 0.3 \\
\hline & Telotarsus length & 0.7 & 0.2 & 0.4 & 0.4 \\
\hline & Total length & 4.3 & 3.6 & 5.7 & 4.6 \\
\hline \multirow[t]{7}{*}{ Leg IV } & Trochanter length & - & 0.3 & 0.2 & - \\
\hline & Femur length & - & 0.9 & 1.2 & - \\
\hline & Patella length & - & 0.4 & 0.5 & - \\
\hline & Tibia length & - & 0.6 & 0.8 & - \\
\hline & Basitarsus length & - & 0.5 & 0.7 & - \\
\hline & Telotarsus length & - & 0.4 & 0.4 & - \\
\hline & Total length & - & 3.0 & 3.8 & - \\
\hline
\end{tabular}



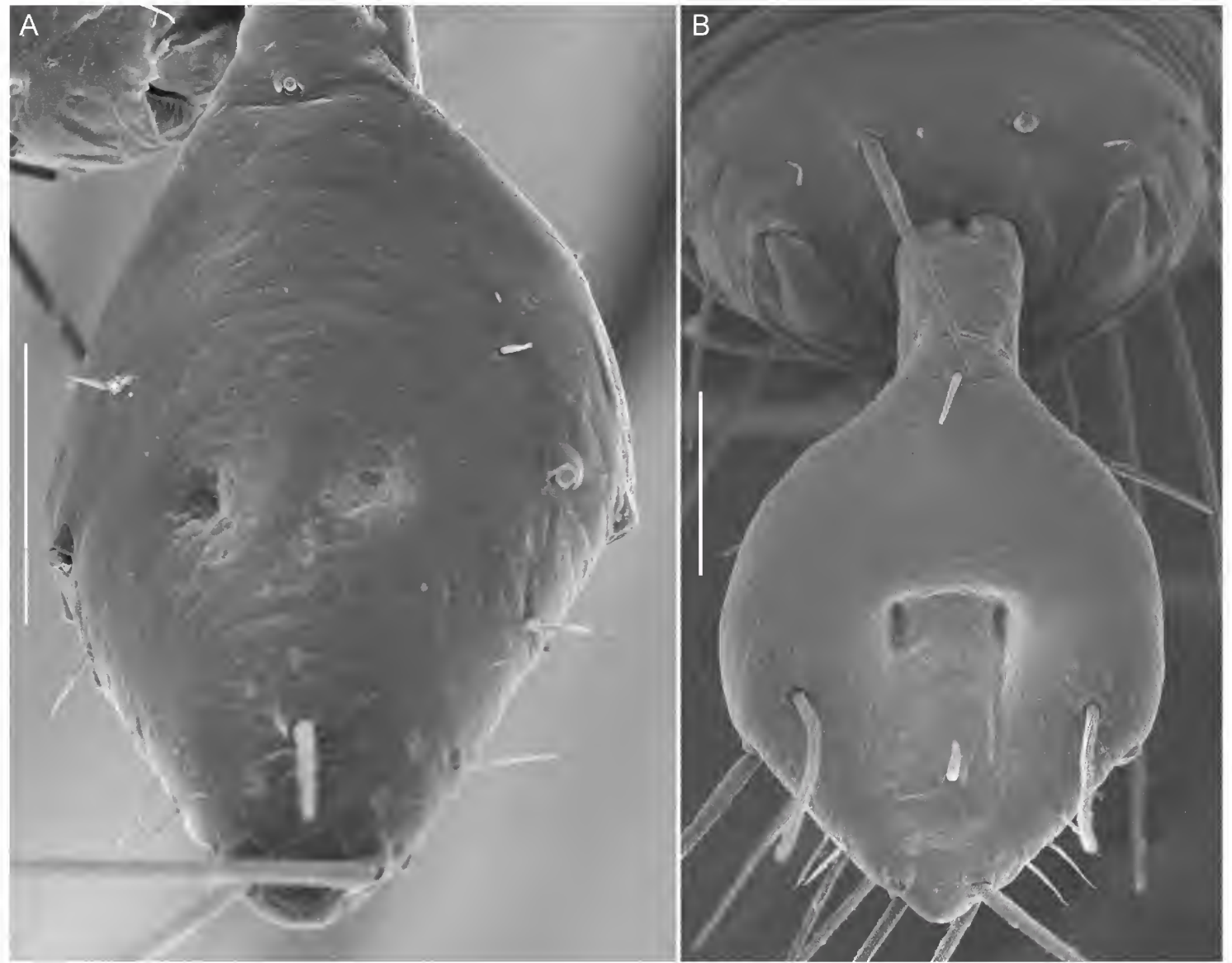

FIG. 20. Short-tailed whipscorpions (Schizomida: Hubbardiidae Cook, 1899), pygidial flagellum, dorsal view, illustrating two types of depressions. A. Nahual bokmai, sp. nov., ơ (CNAN Sz197), pair of dorsosubmedian pits. B. Stenochrus portoricensis Chamberlin, 1922, ठ (CNAN Sz93), submedian depression with two pits embedded in depression. Scale bars $=100 \mu \mathrm{m}$.

Municipio de Tapachula: San José Tacaná, $15^{\circ} 04^{\prime} 07^{\prime \prime} \mathrm{N} 92^{\circ} 05^{\prime} 26^{\prime \prime} \mathrm{W}, 1298 \mathrm{~m}, 7$. iii.2017, G. Contreras, J. Cruz, J. Mendoza, and L. Olguín, 1 ô (CNAN DNA-Sz250).

\section{Heteroschizomus silvino (Rowland} and Reddell, 1977), comb. nov.

Schizomus silvino Rowland and Reddell, 1977:

$80,81,86,89,96,97,99,100$, figs. 3, 19-21;

Rowland, 1975b: 35, 167, 168, 188, 257-259, 261-269, map 4, figs. 237, 245, 246; Row- land and Reddell, 1979a: 163; Reddell, 1981: 54, 126; Rowland and Reddell, 1981: 19, 21-25, figs. 1, 4, 12, 13; Reddell and Cokendolpher, 1995: 6, 115.

Stenochrus silvino: Reddell and Cokendolpher, 1991: 18; 1995: 6, 12, 19, 102, 115; Harvey, 2003: 126; Armas, 2004: 52; Villarreal et al., 2008: 64 .

Type Material: Schizomus silvino: GUATEMALA: Izabal Departament: Gruta de Silvino, 34 km W of Puerto Barrios, 20-22.viii.1969, S. and J. Peck, holotype 0,3 o, 7 ㅇ paratypes (AMNH). 
Natural History: Heteroschizomus silvino, comb. nov., is endemic to Grutas de Silvino, a small cave in which specimens were collected near the entrance and in the main gallery, walking on the walls in the penumbra area.

Additional Material Examined: GUATEMALA: Izabal Departament: Cayuga, Grutas de Silvino, $15^{\circ} 32^{\prime} 49^{\prime \prime} \mathrm{N} 88^{\circ} 42^{\prime} 01^{\prime \prime} \mathrm{W}, 64 \mathrm{~m}$, D. Barrales and R. Monjaraz 17.viii.2017, 3 t, 1 ㅇ (AMCC [LP 14556]), 3 o, 1 q (CNAN DNA-Sz267).

Nahual, gen. nov.

Figures 3, 6, 7F, 9A, B, 10B, 11A, 12B, 13F, 14C, 19G-I, 20A, 21G-L, 22A, B; tables 1, 3, 8

Stenochrus (part): Reddell and Cokendolpher, 1991: 1, 3.

Schizomus mexicanus group (part): Rowland 1975b: 37, 39, 164, 165, 167, 168, 173, 185, $209,214,216,218,220,222,224,228,255$, $280,301,303,320,321,348-350,365,366$, 368, 369, 376, 387, 390-393, 395; Rowland and Reddell, 1979a: 165, 171; 1979b: 90, 107; 1980: 1-10, 11, 15-20; Reddell, 1981: 126; Rowland and Reddell, 1981: 19, 20, 41; Reddell and Cokendolpher, 1986: 32, 34; Camilo and Cokendolpher, 1988: 53, 57; Armas, 1989a: 7; Armas and Abud-Antun, 1990: 14, 18; Reddell and Cokendolpher, 1991: 1, 3; 1995: 82, 99, 101-104; Krüger and Dunlop, 2010: 52; Monjaraz-Ruedas and Francke, 2015: 452; 2016: 781-783, 804; 2018: 189, 212.

Type Species: Schizomus pallidus Rowland, 1975 [= Nahual pallidus (Rowland, 1975), comb. nov.], type species, here designated.

Diagnosis: Nahual, gen. nov., may be separated from other hubbardiid genera by the following combination of characters. Cheliceral movable finger with lamella or single tooth (in Nahual caballero (Monjaraz-Ruedas and Francke, 2018), comb. nov.) (fig. 12B, C); single guard tooth at end of serrula; setal group G3 with G3-3 setae situated anteriorly (except in N. bokmai, sp. nov.) (fig. 13F). Propeltidium anterior process with two anterior setae (one posterior to the other) and three pairs of dorsosubmedian setae (fig. 11A); corneate eyes absent. Metapeltidium entire. Tegument without clavate setae. Pedipalps homeomorphic; trochanter with mesal spur and projected, fan-shaped apical process (fig. 7F); femur $F v_{1}$ and $F v_{2}$ setae spiniform, $F v r_{1-3}$ setae present (seta $\mathrm{Fvr}_{4}$ present in $\mathrm{N}$. lanceolatus, comb. nov., polymorphic in $N$. bokmai and $N$. pallidus, comb. nov.); patella with four or five acuminate $P e$ setae and five feathered $P m$ setae; tibial setal formula 5(6)-5-6 (Ter-Tmr-Tir) (fig. 14C). Leg IV femur anterodorsal margin produced at ca. $90^{\circ}$ angle. Opisthosomal tergite II with one pair of setae $(\mathrm{Dm})$. Opisthosomal segments IX-XII not elongated; XII ( $\hat{0})$ without posterodorsal process. Pygidial flagellum ( $\widehat{\delta})$ dorsoventrally compressed, elliptical (lanceolate in $N$. lanceolatus), with pair of dorsosubmedian circular depressions separated from each other (pits), or circular slumps (in N. caballero) (figs. 19G-I, 20A); flagellum ( $q$ ) with two annuli (fig. $21 \mathrm{G}-\mathrm{L}$ ). Spermathecae ( $q$ ) with two pairs of lobes, of similar width and length; median lobes with apex directed vertically, sclerotized along entire length, sclerotizations increasing in size, creating appearance of leafy tree (fig. 9A, B); lateral lobes with apex directed laterally, unsclerotized; lobes without bulbs; median lobe bases posterior to lateral lobe bases (fig. 10C, D), without duct openings; chitinized arch arrow shaped, with anterior branch linear, lateral tips lobed, wide, and projected; gonopod extremely wide and long, together with chitinized arch, creating appearance of an arrow.

Comparisons: Species of Nahual, gen. nov., resemble species of Stenochrus in the presence of a pair of dorsosubmedian pits in the male pygidial flagellum. However, the flagellum of Nahual possesses only one pair of pits, which are well separated from each other (fig. 20A), whereas the flagellum of Stenochrus possesses an additional dorsal depression associated with the pits, which 

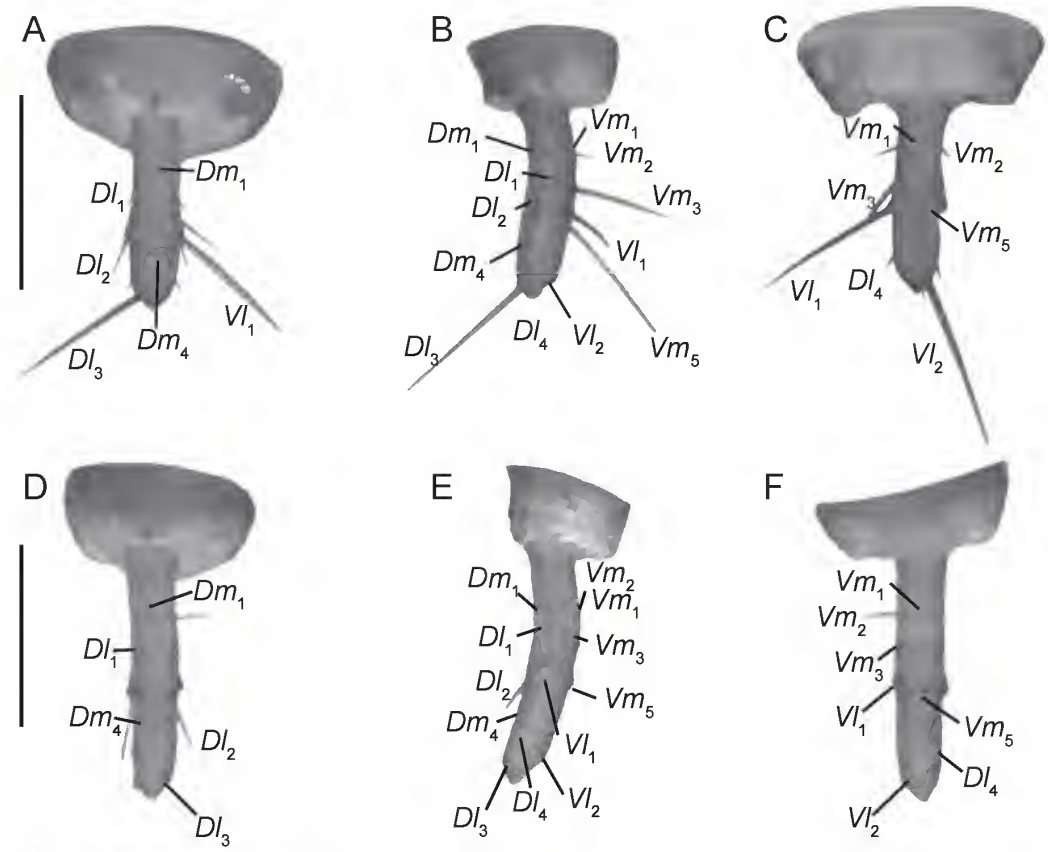

F
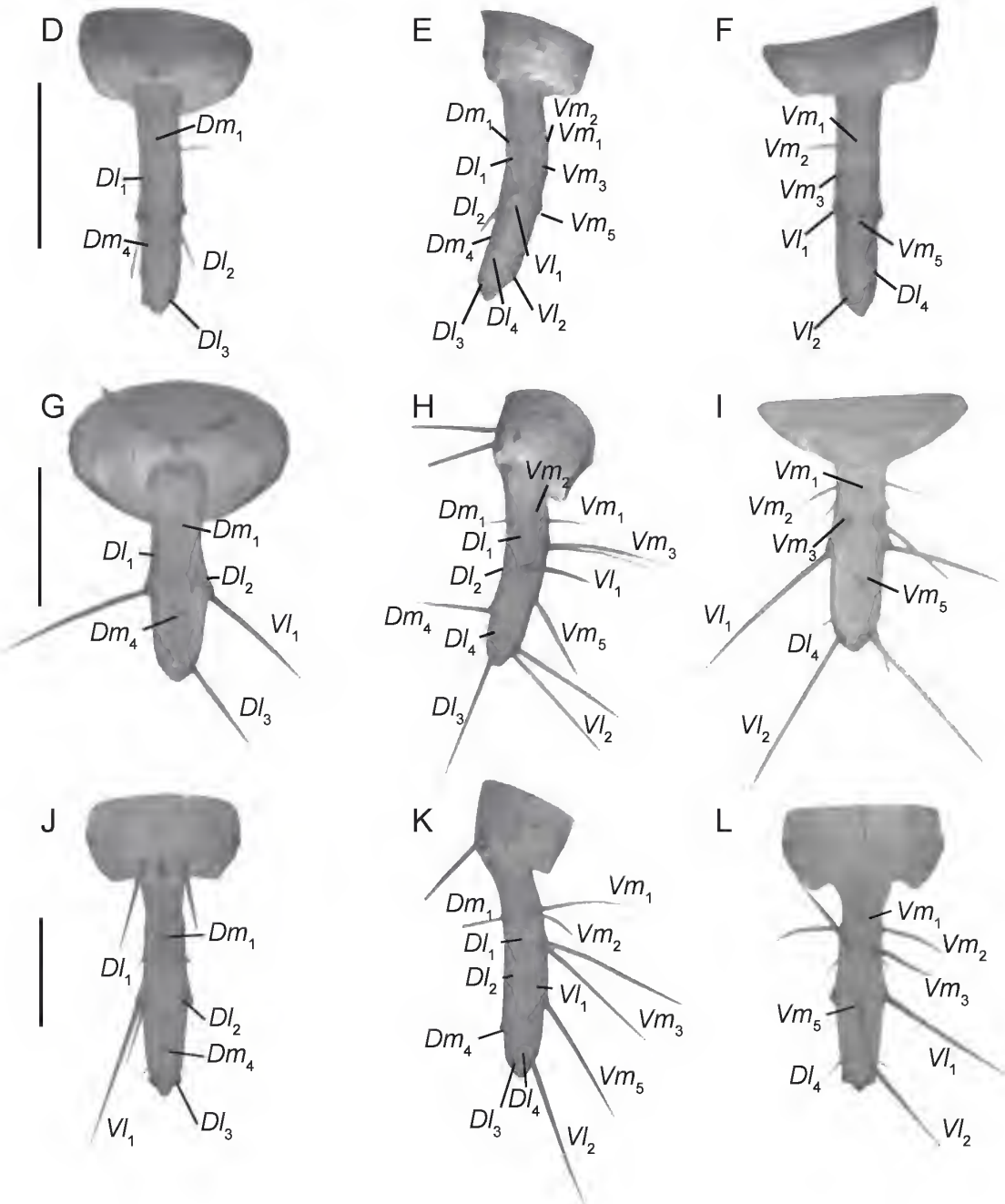

$\mathrm{L}$

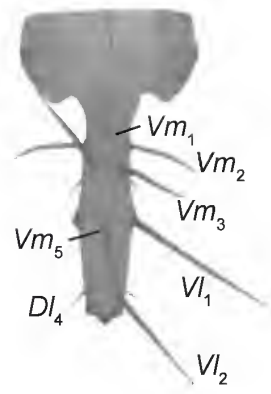

FIG. 21. Short-tailed whipscorpions (Schizomida: Hubbardiidae Cook, 1899), pygidial flagellum, dorsal (A, D, G, J), lateral (B, E, H, K) and ventral (C, F, I, L) views. A-C. Heteroschizomus goodnightorum Rowland, 1973, stat. rev., ㅇ (CNAN Sz171). D-F. Heteroschizomus kekchi, sp. nov., ㅇ (CNAN T1281). G-I. Nahual bokmai, sp. nov., ? (CNAN T1283). J-L. Nahual lanceolatus (Rowland, 1975), comb. nov., \& (CNAN Sz130). Scale bars $=0.2 \mathrm{~mm}$. 
are situated closely adjacent to each other (fig. 20B). Additionally, the $\mathrm{Dl}_{3}$ setae are situated posterior to the $V l_{2}$ setae on the male pygidial flagellum in Nahual, whereas these setae are aligned in Stenochrus. Lastly, species of Nahual possess a lamella on the cheliceral movable finger, which is smooth in Stenochrus.

Species of Nahual also differ from species of Baalrog, gen. nov., and Stenochrus in the presence of spiniform setae $F v_{1}$ and $F v_{2}$ on the pedipalp femur, which are absent in the other genera. The median and lateral lobes of the female spermathecae are linear and similar in length in Nahual, whereas the median lobes are curved, and the lateral lobes reduced in length, in Baalrog and Stenochrus.

The female spermathecae of Nahual resemble those of Heteroschizomus, stat. rev., in possessing median and lateral lobes that are linear and similar in length. However, the lobes are sclerotized in Nahual and unsclerotized in Heteroschizomus.

EтYMology: The generic name is a Nahuatl word used in several Mesoamerican cultures for wizards with the ability to transform themselves into animals. It is masculine in gender.

InCluded Species: Nahual bokmai, sp. nov.; Nahual caballero (Monjaraz-Ruedas and Francke, 2018), comb. nov.; Nahual lanceolatus (Rowland, 1975), comb. nov.; Nahual pallidus (Rowland, 1975), comb. nov.

Distribution: Nahual, gen. nov., is endemic to the Mexican states of Oaxaca and Veracruz (fig. 3). Species of Nahual are codistributed with species of Baalrog, gen. nov., in the Sierra de Zongolica of Veracruz, and extend southward to the Sierra Madre Oriental, in northern Oaxaca. However, species of Nahual are epigean, inhabiting tropical rainforests, and some species occur at elevations above $1800 \mathrm{~m}$, whereas Baalrog are troglobitic, occurring mostly at elevations below $1600 \mathrm{~m}$.

Natural History: Although the type localities of N. lanceolatus, comb. nov., and N. pallidus, comb. nov., are caves, the species of Nahual, gen. nov., are primarily epigean, occurring under rocks and inside rotten logs in tropical forests.
Both N. lanceolatus and N. pallidus have been collected on the surface, suggesting they are facultatively cavernicolous. Baalrog, gen. nov., a strictly cavernicolous genus, is codistributed in the same area as Nahual.

Remarks: Rowland and Reddell (1980) assigned Schizomus lanceolatus Rowland, 1975, to the goodnightorum group, due to the lanceolate shape of the male pygidial flagellum (the female of this species was unknown), and Schizomus pallidus Rowland, 1975, to the mexicanus group, due to the shape of the male pygidial flagellum and the female spermathecae. The discovery of the female of $N$. lanceolatus, comb. nov., demonstrated a close relationship with $N$. pallidus, comb. nov., and supported their inclusion, together with the new species, in Nahual, gen. nov., based on their similar female spermathecae and male pygidial flagella (e.g., with a pair of dorsal pits), as well as DNA sequence data (fig. 6). The enlarged pygidial flagellum of the male of $N$. lanceolatus appears to be autapomorphic and differs from the enlarged flagella observed in species of Heteroschizomus, stat. rev., by the absence of a posterior constriction.

Nahual bokmai, sp. nov.

Figures 3, 6, 7F, 9A, 11A, 13F, 19G-I, 20A, 21G-I, 22A, B; table 1, 8

Type Material: MEXICO: Veracruz: Municipio de Xalapa: Cañadas de Rancho Nuevo (under the bridge), $19^{\circ} 30^{\prime} 17^{\prime \prime} \mathrm{N} 96^{\circ} 47^{\prime} 35^{\prime \prime} \mathrm{W}, 867$ m, 19.vi.2013, A. Cruz, J. Cruz, J. Bokma, O. Francke, R. Monjaraz, and J. Sanchez, holotype o (CNAN T1282), 6.ix.2015, J. Bokma, G. Contreras, O. Francke, J. Mendoza, and R. Monjaraz, 2 o, 2 + paratypes (CNAN T1283).

Diagnosis: Nahual bokmai, sp. nov., may be separated from other species of Nahual, gen. nov., by the following characters: the pedipalp trochanter of the male bears a long, broad, and triangular apical process (fig. 7F); the male pygidial flagellum is elliptical with the posterior half acuminate (fig. 19G-I); the lateral tips of the chitinized arch 
of the female spermathecae (fig. 9A) are extremely widened; and the median and lateral lobes of the spermathecae are linear, with the lateral lobes slightly shorter than the median lobes.

Comparisons: Nahual bokmai, sp. nov., is most closely related to $N$. pallidus, comb. nov., but differs from the latter as follows: adults of $N$. bokmai are larger $(4.7 \mathrm{~mm})$ than adults of $N$. pallidus $(3.4 \mathrm{~mm})$; the apical process on the pedipalp trochanter of the male is broad, triangular and projected in N. bokmai but small, narrow and triangular in N. pallidus; the posterior half of the male pygidial flagellum is acuminate in $N$. bokmai but rounded in $N$. pallidus; and the median and lateral lobes of the female spermathecae are linear, with the lateral lobes slightly shorter than the median lobes, in N. bokmai, whereas the median lobes are curved along their entire length, and the median and lateral lobes are similar in length, in $N$. pallidus.

Eтrmology: The specific name is a patronym, honoring John Bokma, a naturalist and amateur arachnologist, who has discovered many new species of arachnids in the surroundings of Xalapa, and guided the authors to the type locality of this species.

Description: The following description is based on the holotype male and paratype female (fig. 22A, B).

Color: Olive greenish.

Prosoma: Propeltidium with two setae on anterior process; three pairs of dorsal setae; ocular spots distinct, asymmetric. Metapeltidium $0.48 \mathrm{~mm}$ long, $0.74 \mathrm{~mm}$ wide. Anterior sternum with 10 setae, plus two sternophysial setae; posterior sternum with six setae.

Chelicerae: Movable finger with small blunt tooth; serrula with $18(\delta)$ or 19 ( $q$ ) teeth, guard tooth present (fig. 13F). Fixed finger with four small teeth between two primary teeth; setal group formula, 3-6-4-2-9-7-1-7 ( $\hat{0}$ ) or 3-6-4-2-87-1-7 ( + ); G1 with three spatulate setae, covered with spinose spicules; G2 composed of six feathered setae, subequal, shorter than movable finger; G3 with four setae, subequal, feathered apically and smooth basally; G4 consisting of two setae, smooth, thickened basally, elongated apically; G5A with nine subequal setae, feathered apically and longer than fixed finger; G5B with seven feathered setae, subequal; G6 with one smooth seta, ca. 1/2 the length of movable finger; G7 with seven feathered setae, subequal.

Pedipalps: Pedipalps homeomorphic (fig. 7F); $2.16 \times(\delta)$ or $1.7 \times(q)$ longer than propeltidium. Trochanter with broad triangular apical process; prolateral surface with long medial spur. Femur $2.1 \times$ longer than high; retroventral margin with setae $\mathrm{Fe}_{1}$ and $\mathrm{Fe}_{5}$ acuminate, $\mathrm{Fev} \mathrm{v}_{1}$ and $\mathrm{Fev} \mathrm{v}_{2}$ spiniform; prolateral surface with row of three ventral spiniform setae $\left(F m v_{1-3}\right)$ and two dorsal spiniform setae $\left(F m d_{2}, F m d_{3}\right)$. Patella with four acuminate $P e$ setae and five feathered $P m$ setae; without distinctive armature. Tibia setal formula, 5:5:6; Ter acuminate, Tmr and Tir feathered. Tarsal spurs asymmetric.

Legs: Leg I, basitarsal-telotarsal proportions, 33:5:6:6:6:6:14; IV, femur 3.28× longer than high.

Opisthosoma: Tergite I with two pairs of microsetae anteriorly plus pair of $\mathrm{Dm}$ setae; II with three pairs of microsetae anteriorly plus pair of Dm setae; III-VII each with one pair of $D m$ setae; VIII with pairs of $D m$ and $D l_{2}$ setae; IX with pairs of $D l_{1}$ and $D l_{2}$ setae and without pair of $D m$ setae. Segments X and XI telescoped, with pairs of $D l_{2}, V m_{2}, V l_{1}$, and $V l_{2}$ setae plus single $V m_{1}$ seta; XII with pairs of $D m, D l_{1}, D l_{2}$, $V m_{1}, V m_{2}, V l_{1}$, and $V l_{2}$ setae, without posterodorsal process. Sternites II-VII each with two irregular rows of setae; genital plate with many scattered microsetae.

Pygidial flagellum: Flagellum ( $\widehat{A}$ ) dorsoventrally compressed, elliptical (figs. 19G-I, 20A); $1.9 \times$ longer than wide; pair of dorsosubmedian pits present; seta $D m_{1}$ situated over bulb base, $\mathrm{Dm}_{4}$ situated posteriorly, $D l_{2}$ aligned with $V l_{1}$, $\mathrm{Dl}_{3}$ situated posterior to $\mathrm{Vl}_{2}$, pair of $V m_{2}$ setae present, $V m_{1}$ situated posterior to $V m_{2}$; pair of anterodorsal microsetae between $D m_{1}$ and $D l_{2}$, pair of anterolateral microsetae on flagellar pedicel, two patches of microsetae between $V l_{1}$ and $\mathrm{Vl}_{2}$ (msp). Flagellum ( $q$ ) with three flagellomeres (fig. 21G-I); seta $D l_{2}$ reduced, aligned 
with $\mathrm{Vl}_{1}, \mathrm{Dl}_{3}$ situated posterior to $\mathrm{Vl}_{2}, V m_{2}$ present, not reduced, $V m_{1}$ aligned with $V m_{2} ; D l_{1}$ and $\mathrm{Dl}_{4}$ microsetae present.

Female spermathecae: Two pairs of lobes (fig. 9A); median and lateral lobes linear, similar in width; lateral lobes slightly shorter than median lobes (ca. 3/4); median lobes sclerotized apically; median lobe bases anterior to lateral lobe bases. Chitinized arch U-shaped; anterior branch slightly visible, linear; lateral tip very wide, lobate. Gonopod long and wide, subtriangular.

Distribution: This species is known only from the type locality in the Municipio de Xalapa of the state of Veracruz, Mexico (fig. 3).

NATURAL History: All material was collected under rocks in a primary tropical rainforest along the banks of the Actopan River, near Xalapa. The locality is situated at the bottom of a deep, narrow glen, which maintains a high humidity.

Additional Material Examined: MEXICO: Veracruz: Municipio de Xalapa: Cañadas de Rancho Nuevo (under the bridge), $19^{\circ} 30^{\prime} 17^{\prime \prime} \mathrm{N}$ $96^{\circ} 47^{\prime} 35^{\prime \prime} \mathrm{W}, 867 \mathrm{~m}, 19 . v i .2013$, J. Bokma, G. Contreras, O. Francke, J. Mendoza, and R. Monjaraz, 3 ઈิ, 7 o (CNAN Sz197), 6.ix.2015, J. Bokma, A. Cruz, J. Cruz, O. Francke, R. Monjaraz, and J. Sanchez, 3 of (AMCC [LP 14519]), 2 ㅇ (CNAN Sz198).

\section{Nahual caballero (Monjaraz-Ruedas and Francke, 2018), comb. nov.}

Stenochrus caballero Monjaraz-Ruedas and

Francke, 2018: 199-202, figs. 29-42, 71.

Type Material: Stenochrus caballero: MEXICO: Oaxaca: Municipio de San José Tenango: Cerro Caballero, $18^{\circ} 08^{\prime} 32^{\prime \prime} \mathrm{N} 96^{\circ} 42^{\prime} 57^{\prime \prime} \mathrm{W}, 938$ m, 10.iv.2014, G. Contreras, J. Cruz, S. Davlantes, O. Francke and J. Mendoza, holotype $\hat{\delta}$ (CNAN T1157), 28.viii.2008, J. Cruz, 1 t, 1 q paratypes (CNAN T1158); Pozo de Águilas, 0.6 $\mathrm{km} \mathrm{N}, 18^{\circ} 11^{\prime} 52^{\prime \prime} \mathrm{N} 96^{\circ} 40^{\prime} 37^{\prime \prime} \mathrm{W}, 327 \mathrm{~m}, 11$. iv.2014, G. Contreras, J. Cruz, S. Davlantes, O. Francke, and J. Mendoza, $1 \delta, 1$ q paratypes (CNAN T1159).
Remarks: Nahual caballero, comb. nov., differs markedly from other species of the genus in several respects, e.g., the presence of a tooth instead of a lamella on the cheliceral movable finger, three $P e$ setae and four $P m$ setae on the pedipalp patella, a tibial setal formula of 4-3-5, and unsclerotized lobes of the female spermathecae. Despite these differences, however, the placement of this species within Nahual, gen. nov., was strongly supported by the phylogenetic analyses (fig. 6) based on the shape of the male pygidial flagellum and the female spermathecae, with lobes of similar length, a chitinized arch with lateral tips projected, and a wide and extremely long gonopod.

Additional Material Examined: MEXICO: Oaxaca: Municipio de San José Tenango: Cerro Caballero, $18^{\circ} 08^{\prime} 32^{\prime \prime} \mathrm{N} 96^{\circ} 42^{\prime} 57^{\prime \prime} \mathrm{W}, 938$ m, 12.iv.2016, D. Barrales, G. Contreras, J. Cruz, J. Mendoza, and R. Monjaraz, 1 ㅇ (AMCC [LP 14514]).

\section{Nahual lanceolatus (Rowland, 1975), comb. nov.}

Figures 3, 6, 9B, 14C, 21J-L; table 8

Schizomus lanceolatus Rowland, 1975a: 6, 7, 15-17, fig. 7; 1975b: 34, 167, 168, 257, 258, 261-268, map 4, figs. 235, 243; Rowland and Reddell, 1977: 80, 86, 99, 100, fig. 3; 1979a: 163; Reddell, 1981: 46, 126, 127, fig. 22; Rowland and Reddell, 1981: 19, 21, 23-27, figs. 1, 2, 10; Zacharda and Elliott, 1985: 477; Reddell and Cokendolpher, 1995: 6, 107.

Stenochrus lanceolatus: Reddell and Cokendolpher, 1991: 18; 1995: 6, 12, 18, 102, 107; Vázquez-Rojas, 1995: 34; 1996: 65; Harvey, 2003: 124; Villarreal et al., 2008: 64, 64; Palacios-Vargas and Reddell, 2013: 52; Palacios-Vargas et al., 2015: 32.

Type Material: Schizomus lanceolatus: MEXICO: Veracruz: Municipio de Ciudad Mendoza: Cueva del Diablo, 7.iii.1973, J. Reddell, holotype ô (AMNH). 
Supplementary Description: The following description of the female is based on the Additional Material Examined.

Prosoma: Propeltidium with two apical setae; three pairs of dorsal setae.

Chelicerae: Movable finger with small lamella; serrula with 26 teeth, guard tooth present. Fixed finger with three small teeth between two primary teeth; setal group formula, 3-6-4-2-10-6-1-6.

Pedipalps: Pedipalps homeomorphic; $1.89 \times$ longer than propeltidium. Trochanter with small triangular apical process; prolateral surface with small medial spur. Femur $1.7 \times$ longer than high; retroventral margin with setae $\mathrm{Fe}_{1}, \mathrm{Fe}_{5}, \mathrm{Fev}_{1}$, and $\mathrm{Fev}_{2}$ spiniform; prolateral surface with row of four ventral spiniform setae $\left(F m v_{1-4}\right)$ and two dorsal spiniform setae $\left(F m d_{2}, F m d_{3}\right)$. Patella with four acuminate $P e$ setae and five feathered $P m$ setae; without distinctive armature. Tibia setal formula, 5:5:6; Ter acuminate, Tmr and Tir feathered. Tarsal spurs asymmetric.

Opisthosoma: Segments X-XII not elongated.

Pygidial flagellum: Flagellum ( + ) with three flagellomeres (fig. 21J-L); seta $D l_{2}$ not reduced, situated anterior to $\mathrm{Vl}_{1}, \mathrm{Dl}_{3}$ situated posterior to $V l_{2}, V m_{2}$ present, not reduced, $V m_{1}$ aligned with $V m_{2} ; D l_{1}$ and $D l_{4}$ microsetae present.

Female spermathecae: Two pairs of lobes (fig. 9B); median and lateral lobes similar in length and width; median lobes linear, lateral lobes sublinear, apex slightly curved laterally; median lobes sclerotized along entire length, lateral lobes sclerotized apically; median lobe bases posterior to lateral lobe bases. Chitinized arch rectangular; anterior branch linear; lateral tips elongated. Gonopod subtriangular; length ca. $2 \times$ width.

Natural History: Although the type locality of $N$. lanceolatus, comb. nov., Cueva del Diablo, is a large cave with a dark zone, adults of both sexes were also found on the surface in the foothills of Pico de Orizaba, Veracruz, indicating that this species is facultatively and not obligatorily cavernicolous.

REMARKs: Rowland and Reddell (1980) placed this species in the goodnightorum group of Schizomus because of the lanceolate shape of the male pygidial flagellum. The recent discovery of the female, as well as the comparison of DNA sequence data, has demonstrated that it is more closely related to the species accommodated in Nahual, gen. nov., however. The male flagellum lacks the posterior constriction observed in all species of Heteroschizomus, stat. rev., and shares with other species of Nahual a pair of pits separated from each other. The well-developed apical process of the pedipalp trochanter and the spiniform setae on the pedipalp trochanter, tibia, and patella further support the placement of this species.

Additional Material Examined: MEXICO: Puebla: Municipio de La Esperanza: La Calera (path to Pico de Orizaba), $18^{\circ} 52^{\prime} 04^{\prime \prime} \mathrm{N}$ $97^{\circ} 18^{\prime} 51^{\prime \prime} \mathrm{W}, 2729 \mathrm{~m}, 24 . i i .2012$, D. Barrales, J. Mendoza, A. Ortega, C. Santibañez, and A. Valdez, 2 ô, 1 imm. (CNAN Sz130), 21.ix.2015, J. Arreguin, D. Barrales, O. Francke, D. Guerrero, and R. Monjaraz, 2 \& (CNAN DNA-Sz241), 1 우 (AMCC [LP 14538]). Veracruz: Municipio de Ciudad Mendoza: Cueva del Diablo, $18^{\circ} 47^{\prime} 00^{\prime \prime} \mathrm{N}$ $97^{\circ} 11^{\prime} 27^{\prime \prime} \mathrm{W}, 1385$ m, 20.ix.2015, J. Arreguin, D. Barrales, O. Francke, D. Guerrero, and R. Monjaraz, 2 o, 2 우 (CNAN Sz169).

Nahual pallidus (Rowland, 1975), comb. nov.

Schizomus pallidus Rowland, 1975a: 6, 7, 13-15, 17, fig. 6; 1975b: 34, 166-169, 184-186, 188, $216-219,222,223,228,230,280,366-369$, 396, map 5, figs. 166, 179, 196, 292; Rowland and Reddell, 1977: 80, 84, 87-89, fig. 2; 1979a: 163; 1980: 1, 2, 4, 5, 10, 11, 13, 15, 16, 19, figs. 1, 13, 26, 43; Reddell, 1981:17, 45, 46, 128, 129, 321, 324, fig. 23; Camilo and Cokendolpher, 1988: 57; Reddell and Cokendolpher, 1995: 6, 109.

Stenochrus pallidus: Reddell and Cokendolpher, 1991: 18; 1995: 6, 12, 18, 102, 103, 109; Vázquez-Rojas, 1995: 34; 1996: 65; Harvey, 2003: 125; Palacios-Vargas and Reddell, 2013: 52; Palacios-Vargas et al., 2015: 32; Monjaraz-Ruedas and Francke, 2018: 200, 201, 212. 
Type Material: Schizomus pallidus: MEXICO: Veracruz: Municipio de Tlilapan: Cueva Macinga, 5.iii.1973, J. Reddell, holotype $\hat{\delta}$, paratype ㅇ (AMNH).

Natural History: Cueva Macinga, the type locality of N. pallidus, comb. nov., is a small, shallow cave without penumbra or dark zone. Specimens of $N$. pallidus were also collected in epigean habitats in the surroundings of Cueva Macinga and at another locality, Rancho San Fermín, indicating that this species is facultatively cavernicolous.

Additional Material Examined: MEXICO: Veracruz: Municipio de Atoyac: Rancho San Fermín, $18^{\circ} 54^{\prime} 30^{\prime \prime} \mathrm{N} 96^{\circ} 49^{\prime} 19^{\prime \prime} \mathrm{W}, 542 \mathrm{~m}, 16.1 .2017$, D. Barrales, G. Contreras, and R. Monjaraz, 3 ot, 1 (CNAN DNA-Sz220), 1 ô, 1 imm. (AMCC [LP 14524]). Municipio Amatlán de los Reyes: Cañada Blanca, $18^{\circ} 57^{\prime} 10^{\prime \prime} \mathrm{N} 96^{\circ} 51^{\prime} 19^{\prime \prime} \mathrm{W}, 788 \mathrm{~m}$, 19.viii.2017, D. Barrales, A. Cruz, J. Mendoza, and R. Monjaraz, 1 ㅇ (AMCC [LP 14557]).

\section{Olmecazomus, nom. nov.}

Figure 6; tables 1, 3

Olmeca Monjaraz-Ruedas and Francke, 2017: 399-413 (junior homonym of Olmeca Lamothe-Argumedo and Pineda-López, 1990).

Type Species: Olmeca cruzlopezi MonjarazRuedas and Francke, 2017 [= Olmecazomus cruzlopezi (Monjaraz-Ruedas and Francke, 2017), comb. nov.], type species, by original designation.

Diagnosis: Olmecazomus, nom. nov., may be separated from other hubbardiid genera by the following combination of characters. Cheliceral movable finger without accessory tooth; single guard tooth at end of serrula; setal group G3 with setae G3-4 situated basally. Propeltidium anterior process with two anterior setae (one posterior to the other) and two pairs of dorsosubmedian setae; corneate eyes absent, one pair of eyespots present. Metapeltidium entire. Tegument without clavate setae. Pedipalps homeomorphic; trochanter with prolateral spur and projected, digitiform apical process; femur $F e_{2}$ setae spiniform, $F v_{1}$ and $F v_{2}$ setae forming well-developed spiniform setiferous tubercles, located retroventrally; tibia with $\mathrm{Ter}_{7}$ and $\mathrm{Tir}_{5}$ setae spiniform, strongly sclerotized. Leg IV femur anterodorsal margin produced at ca. $90^{\circ}$ angle. Opisthosomal tergite II with one pair of setae $(D m)$. Opisthosomal segments IXXII not elongated; XII ( $\widehat{\delta}$ ) without posterodorsal process. Pygidial flagellum $(\hat{O})$ dorsoventrally compressed, elliptical or ovate, with pair of dorsosubmedian slumps fused posteriorly; flagellum ( $q$ ) with two annuli. Spermathecae ( + ) with two pairs of lobes, lateral lobes wider and smaller than medial lobes (ca. 1/3 the length of median lobes); lateral lobes swollen, drop shaped; median lobes parenthesis shaped, with apex directed laterally, and without bulbs; lateral and median lobes apically sclerotized; chitinized arch V-shaped, without anterior branch; lateral tips lobed; gonopod wide and long.

Comparisons: Species of Olmecazomus resemble species of Heteroschizomus in the shape of the female spermathecae, with the lateral lobes approximately $1 / 4$ the length of median lobes. However, the chitinized arch is V-shaped in Olmecazomus and mug shaped in Heteroschizomus. Males of Olmecazomus also resemble males of Mayazomus in the robust pedipalps and the presence of spiniform setiferous tubercles on the pedipalp femur. However, pedipalp tibial setae $\mathrm{Ter}_{7}$ and $\mathrm{Tir}_{5}$ are spiniform and prolateral tarsal spurs are absent in males of Olmecazomus, whereas $\operatorname{Ter}_{7}$ and $\operatorname{Tir}_{5}$ are acuminate, and large prolateral tarsal spurs are present in males of Mayazomus.

EтyMology: The generic name is a compound word, derived from the word Olmeca, honoring the Olmecs, a prehispanic Mexican tribe, and zomus, a suffix commonly used for schizomid genera. It is masculine in gender.

InCluded SPECIES: Olmecazomus brujo (Monjaraz-Ruedas and Francke, 2017), comb. nov.; Olmecazomus cruzlopezi (Monjaraz-Ruedas and Francke, 2017), comb. nov.; Olmecazomus santibanezi (Monjaraz-Ruedas and Francke, 2017), comb. nov. 
REMARKs: The name Olmeca was first used for a trematode worm, Olmeca Lamothe-Argumedo and Pineda-López, 1990. A search in Neave's Nomenclator Zoologicus (2005) did not capture this name, which is valid and has nomenclatural priority according to the ICZN (2000). Olmecazomus, nom. nov., is therefore designated as a replacement name for members of the junior homonym, Olmeca Monjaraz-Ruedas and Francke, 2017.

Pacal Reddell and Cokendolpher, 1995

Figures 1, 6; tables 1, 3

Pacal Reddell and Cokendolpher, 1995: 1, 10, 13-15, 87, 88, 117, 140-142; Harvey, 2003: 114; Villarreal et al., 2008: 65; MontañoMoreno and Francke, 2009: 33; MonjarazRuedas, 2012: 63; Moreno-González and Villarreal, 2012: 73, 75; Monjaraz-Ruedas and Francke, 2015: 452, 454, 461, 464, 475; 2016: 782-784, 787, 790, 804; Monjaraz-Ruedas et al., 2016: 120, 131; Monjaraz-Ruedas and Francke, 2017: 399-401, 405, 408, 411.

Schizomus brasilensis group (part): Rowland 1975b: 37-39, 127-132, 134, 151, 152, 154, $156,158,160,241,305,320,321,324,335$, 348-350, 360, 361, 363, 376, 384-388, 390, 393; Rowland and Reddell, 1979a: 165, 171; 1979b: 89, 90, 103, 105-112, 114, 116, 118; 1980: 1, 3; Reddell, 1981: 126; Rowland and Reddell, 1981: 19, 20; Reddell and Cokendolpher, 1984: 172, 176, 177; 1986: 32; 1991: 3.

Type Species: Schizomus lacandonus Rowland, 1975 [= Pacal lacandonus (Rowland, 1975)], type species, by original designation.

Diagnosis: Pacal may be separated from other hubbardiid genera by the following combination of characters. Cheliceral movable finger with lamella; single guard tooth at end of serrula; setal group G3 with G3-4 setae situated posteriorly. Propeltidium anterior process with two anterior setae (one posterior to the other) and three pairs of dorsosubmedian setae; corneate eyes absent. Metapeltidium entire. Tegument without clavate setae. Pedipalps homeomorphic; trochanter with small prolateral spur and acuminate apical process; femur $F v_{1}$ and $F v_{2}$ setae acuminate, $F_{v r_{1-3}}$ setae present; patella with three acuminate $\mathrm{Pe}$ setae and four feathered $\mathrm{Pm}$ setae; tibial setal formula 3-3-5(4) (Ter-Tmr-Tir). Leg IV femur anterodorsal margin produced at ca. $90^{\circ}$ angle. Opisthosomal tergite II with one pair of setae $(D m)$. Opisthosomal segments IX-XII not elongated; XII ( $\hat{o}$ ) with small, inconspicuous posterodorsal process. Pygidial flagellum ( $\vec{o})$ dorsoventrally compressed, trilobed or rhomboid, with pair of dorsomedian circular depressions (pits) and pair of dorsosubmedian swellings; flagellum ( + ) with two annuli. Spermathecae ( $q$ ) with one pair of lobes (two pairs in Pacal moisii (Rowland, 1973), comb. nov., and Pacal tepezcuintle (Armas and Cruz-López, 2009), comb. nov.), apex directed vertically, unsclerotized; lobes with large and prominent terminal bulbs and several duct openings; chitinized arch inverse arch shaped, with anterior branch curved and complete, lateral tips tapering; gonopod short and small.

Comparisons: Species of Pacal may be separated from other hubbardiid genera by the presence of only one pair of spermathecal lobes in the female, and large bulbs on the lobes, which are absent in the spermatheca of other North American genera. In addition, males possess a lamella on the cheliceral movable finger and a small, inconspicuous posterodorsal process on opisthosomal segment XII, unique among North American schizomid genera, except Hubbardia, which exhibits a large, well-developed posterodorsal process on segment XII.

Included Species: Pacal lacandonus (Rowland, 1975); Pacal moisii (Rowland, 1973), comb. nov.; Pacal stewarti (Rowland, 1973); Pacal tepezcuintle (Armas and Cruz-López, 2009), comb. nov.; Pacal trilobatus (Rowland, 1975).

Remarks: As redefined above, Pacal comprises three species previously assigned to the genus and two species newly transferred from Stenochrus. Although P. moisii, comb. nov., and 


\section{TABLE 8}

Measurements (mm) of the short-tailed whipscorpions, Nahual bokmai, sp. nov., and Nahual lanceolatus (Rowland, 1975), comb. nov. (Schizomida: Hubbardiidae Cook, 1899)

Material deposited in the National Collection of Arachnida (CNAN) at the National Autonomous University of Mexico.

\begin{tabular}{|c|c|c|c|c|c|c|c|}
\hline & & \multicolumn{5}{|c|}{ N. bokmai } & N. lanceolatus \\
\hline \multicolumn{2}{|l|}{ Sex } & $\delta$ & & & q & & $q$ \\
\hline \multicolumn{2}{|l|}{ Collection } & CNAI & & & CNAN & & CNAN \\
\hline \multicolumn{2}{|l|}{ Number } & $\mathrm{T} 1282$ & & & $\mathrm{~T} 1283$ & & Sz0169 \\
\hline \multicolumn{2}{|l|}{ Total length } & 4.7 & 4.1 & 4.1 & 4.2 & 3.9 & 5.1 \\
\hline \multirow[t]{2}{*}{ Propeltidium } & Length & 1.4 & 1.4 & 1.4 & 1.3 & 1.3 & 1.7 \\
\hline & Width & 0.8 & 0.7 & 0.7 & 0.7 & 0.8 & 0.9 \\
\hline \multirow[t]{3}{*}{ Flagellum } & Length & 0.5 & 0.5 & 0.5 & 0.3 & 0.4 & 0.5 \\
\hline & Width & 0.3 & 0.3 & 0.2 & 0.1 & 0.1 & 0.1 \\
\hline & Height & 0.2 & 0.1 & 0.1 & 0.1 & 0.1 & 0.1 \\
\hline \multirow[t]{6}{*}{ Pedipalp } & Trochanter length & 0.7 & 0.6 & 0.5 & 0.5 & 0.5 & 0.7 \\
\hline & Femur length & 0.7 & 0.6 & 0.6 & 0.5 & 0.6 & 0.7 \\
\hline & Patella length & 0.7 & 0.6 & 0.6 & 0.5 & 0.6 & 0.7 \\
\hline & Tibia length & 0.6 & 0.5 & 0.6 & 0.5 & 0.5 & 0.6 \\
\hline & Tarsus length & 0.3 & 0.2 & 0.3 & 0.3 & 0.2 & 0.3 \\
\hline & Total length & 3.0 & 2.6 & 2.6 & 2.3 & 2.4 & 3.1 \\
\hline \multirow[t]{8}{*}{ Leg I } & Coxa length & 0.8 & 0.8 & 0.7 & 0.6 & 0.6 & 0.8 \\
\hline & Trochanter length & 0.5 & 0.5 & 0.5 & 0.4 & 0.4 & 0.5 \\
\hline & Femur length & 2.1 & 1.9 & 1.9 & 1.2 & 1.3 & 1.6 \\
\hline & Patella length & 2.6 & 2.4 & 2.2 & 1.5 & 1.6 & 1.9 \\
\hline & Tibia length & 1.8 & 1.7 & 1.3 & 1.1 & 1.2 & 1.4 \\
\hline & Basitarsus length & 0.5 & 0.5 & 0.5 & 0.4 & 0.4 & 0.5 \\
\hline & Telotarsus length & 0.7 & 0.7 & 0.7 & 0.5 & 0.5 & 0.5 \\
\hline & Total length & 9.0 & 8.3 & 7.7 & 5.6 & 6.1 & 7.1 \\
\hline \multirow[t]{7}{*}{ Leg IV } & Trochanter length & 0.4 & 0.3 & 0.4 & 0.4 & 0.4 & - \\
\hline & Femur length & 1.7 & 1.6 & 1.6 & 1.2 & 1.4 & - \\
\hline & Patella length & 0.7 & 0.6 & 0.7 & 0.5 & 0.6 & - \\
\hline & Tibia length & 1.2 & 1.2 & 1.1 & 0.9 & 0.9 & - \\
\hline & Basitarsus length & 0.6 & 1.0 & 1.0 & 0.8 & 0.9 & - \\
\hline & Telotarsus length & 0.4 & 0.6 & 0.6 & 0.5 & 0.6 & - \\
\hline & Total length & 5.1 & 5.4 & 5.5 & 4.3 & 4.8 & - \\
\hline
\end{tabular}



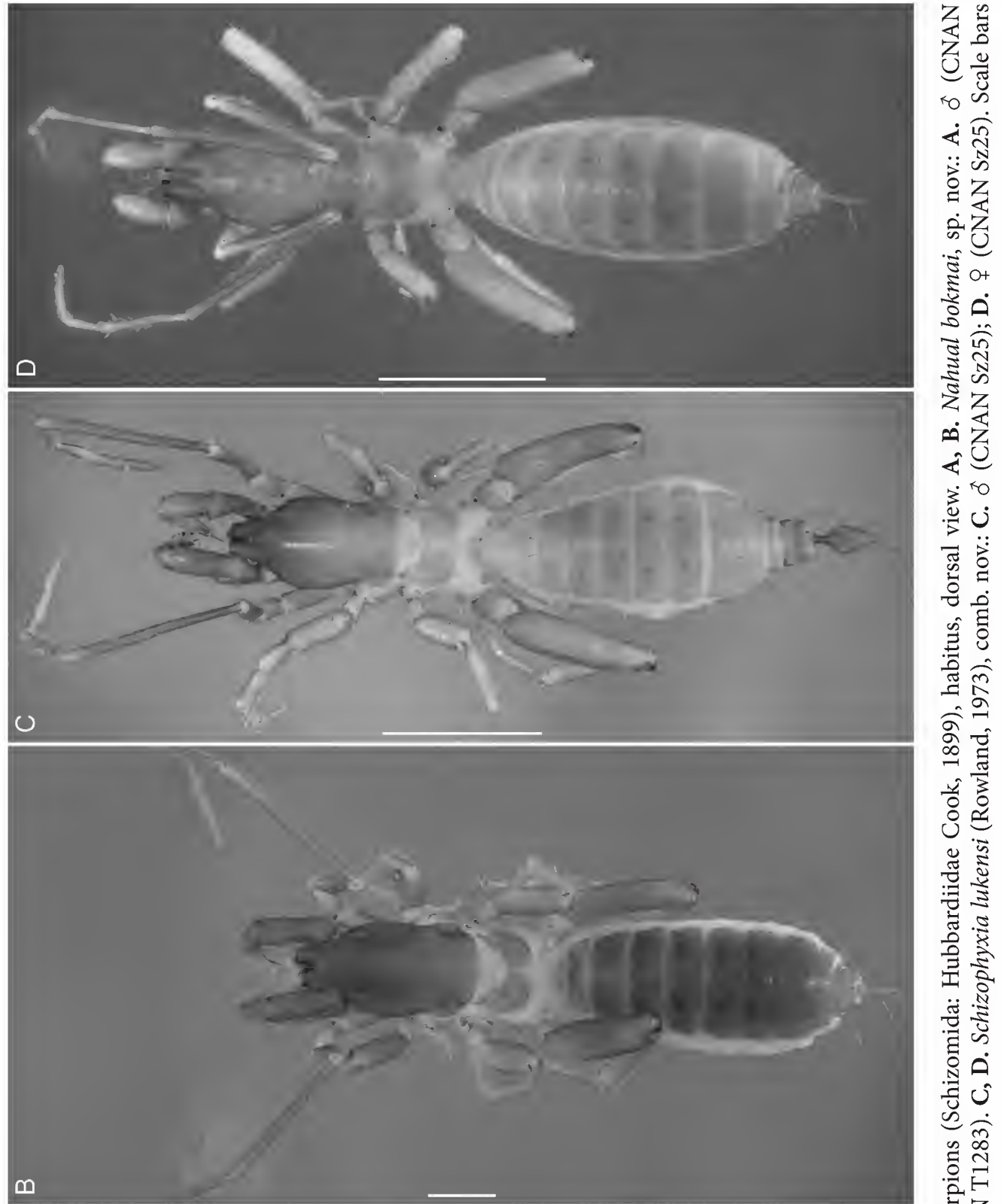

$m$

客

范

象

च

की

ลิ

工ิ

$\hat{2}$

शे छै

$\hat{\imath}$

8

范

:을

สี

है

능

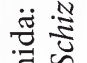

ด

ำ

迥

क ल

드

룽

긍

至

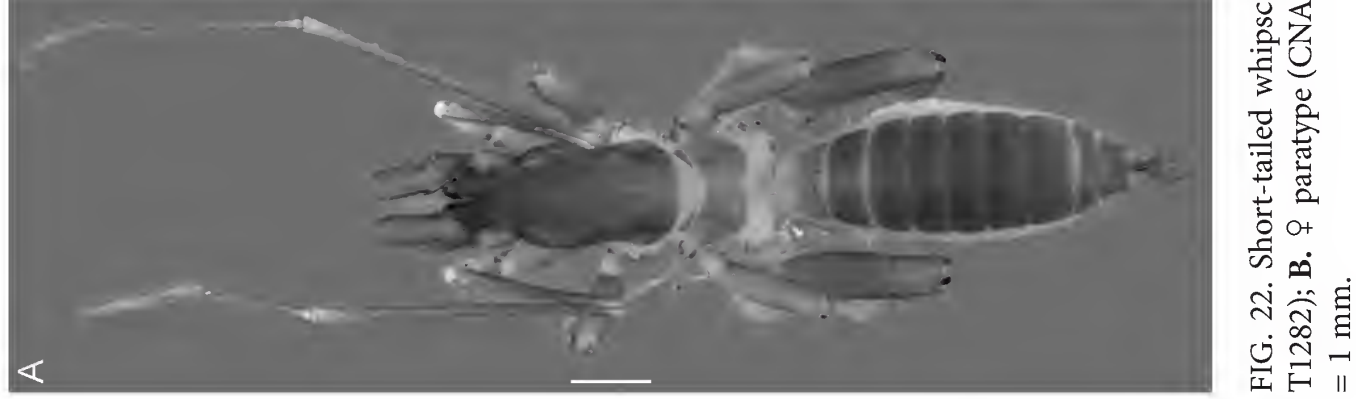


P. tepezcuintle, comb. nov., are morphologically similar and differ markedly from other members of Pacal, the two species grouped unequivocally with other species of the genus based on the molecular data (fig. 6). The description of other new species awaits a more detailed revision of the genus.

\section{Schizophyxia, gen. nov.}

Figures 2, 6, 7G, 9C, 10A, 13G, 22C, D, 23A-C, $24 \mathrm{~A}-\mathrm{C}$; tables 1,4

Schizomus mexicanus group (part): Rowland, 1975b: 37, 39, 164, 165, 167-168, 173, 185, $209,214,216,218,220,222,224,228,255$, $280,301,303,320,321,348-350,365,366$, $368,369,376,387,390,391-393,395$; Rowland and Reddell, 1979a: 165, 171; 1979b: 90, 107; 1980: 1-8, 10, 11, 15-20; Reddell, 1981: 126; Rowland and Reddell, 1981: 19, 20, 41; Reddell and Cokendolpher, 1986: 32, 34; Camilo and Cokendolpher, 1988: 53, 57; Armas, 1989a: 7; Armas and Abud-Antun, 1990: 14, 18; Reddell and Cokendolpher, 1991: 1, 3; 1995: 82, 99, 101-104; Krüger and Dunlop, 2010: 52; Monjaraz-Ruedas and Francke, 2015: 452; 2016: 781-783, 804; 2018: 189, 212.

Type Species: Schizomus lukensi Rowland, 1973 [= Schizophyxia lukensi (Rowland, 1973), comb. nov.], type species, here designated.

Diagnosis: Schizophyxia, gen. nov., may be separated from other hubbardiid genera by the following combination of characters. Cheliceral movable finger smooth; single guard tooth at end of serrula; setal group G3 with G3-3 setae situated anteriorly (fig. 13G). Propeltidium anterior process with two anterior setae (one posterior to the other) and three pairs of dorsosubmedian setae (fig. 11A); corneate eyes absent. Metapeltidium entire. Tegument without clavate setae. Pedipalps homeomorphic; trochanter with mesal spur, apical process acute, not projected (fig. $7 \mathrm{G}$ ); femur $F v_{1}$ and $F v_{2}$ setae acuminate, $F v r_{1-3}$ setae present; patella with four acuminate $P e$ setae and four feathered $P m$ setae; tibial setal formula 3-3-4 (TerTmr-Tir) (fig. 14D). Leg IV femur anterodorsal margin produced at ca. $90^{\circ}$ angle. Opisthosomal tergite II with one pair of setae $(\mathrm{Dm})$. Opisthosomal segments IX-XII not elongated; XII (ô) without posterodorsal process. Pygidial flagellum (ठ) dorsoventrally compressed, spear shaped, with pair of shallow dorsosubmedian depressions (slightly visible in S. lukensi) not fused posteriorly (fig. 23A-C); flagellum ( 9 ) with two annuli (fig. $24 \mathrm{~A}-\mathrm{C})$. Spermathecae $(q)$ with two pairs of lobes; lateral lobes ca. $3 / 4$ the length of median lobes, with apex directed laterally; median lobes linear or slightly curved laterally (parenthesis shaped); lobes unsclerotized apically and without bulbs; lobe bases aligned, with duct openings along entire length (figs. 9C, 10A); chitinized arch U-shaped, without anterior branch, lateral tips rounded; gonopod wide and short.

Comparisons: Species of Schizophyxia, gen. nov., resemble species of Harveyus, gen. nov., in the shape of the male pygidial flagellum and the female spermathecae. However, the male pygidial flagellum possesses a pair of submedian depressions and bulbs are absent from the median lobes of the female spermathecae in Schizophyxia, whereas the male pygidial flagellum possesses a pair of shallow pits and small bulbs are present on the median lobes of the female spermathecae in Harveyus. Additionally, species of Schizophyxia bear three pairs of dorsal setae on the propeltdium, whereas species of Harveyus bear only two. Although not observed in Schizophyxia, dimorphic males have been recorded in two species of Harveyus, i.e., H. mexicanus, comb. nov., and H. mulaiki, comb. nov.

EтyMology: The generic name is a compound word, combining schizo-, referring to the order Schizomida, which means "split" in Greek, and phyxia, referring to fictional antlike soldiers in "De-Loused in the Comatorium," a short story by Cedric Bixler-Zavala and Jeremy Michael Ward of the progressive rock band, the Mars Volta. It is neuter in gender. 
InCluded Species: Schizophyxia bartolo (Rowland, 1973), comb. nov.; Schizophyxia lukensi (Rowland, 1973), comb. nov.

Distribution: Schizophyxia, gen. nov., is distributed in the states of Nuevo León and Tamaulipas, northern Mexico (fig. 2), an area also inhabited by some species of Harveyus, gen. nov.

Natural History: The species of Schizophyxia, gen. nov., occur in seasonally dry habitats, inhabiting deciduous forest and caves, where the humidity is more optimal.

Remarks: Although the species of Schizophyxia, gen. nov., and Harveyus, gen. nov., are very similar morphologically, the two genera may be consistently separated by several characters of the male pygidial flagellum and the female spermathecae. The acquisition of DNA sequence data for $H$. mulaiki, comb. nov., and $H$. reddelli, comb. nov., are needed to test the generic placements of these species.

\section{Schizophyxia bartolo (Rowland, 1973), comb. nov.}

Schizomus bartolo Rowland, 1973a: 6, 7, 13-16, 18, 19, figs. $11-13$; 1973c: 135, 137; 1975b: 34, 166-169, 173, 174, 176, 177, 214, 215, $218,219,222,223,228,229,366-369,394$, map 5, figs. 158, 174, 193, 292; Dumitresco, 1977: 157; Rowland and Reddell, 1977: 80, 83, 84, fig. 2; 1979a: 163; 1980: 1, 2, 4-10, 15, 19, figs. 1, 5, 21, 40; Reddell, 1981: 16, 27, 126, 127, 128, 319, 324, fig. 23; Humphreys et al., 1989: 193; Reddell and Cokendolpher, 1995: 5, 105.

Stenochrus bartolo: Reddell and Cokendolpher, 1991: 18; 1995: 5, 12, 18, 102, 103, 105; VázquezRojas, 1995: 33; 1996: 65; Ruíz and Coronado, 2002: 67; Harvey, 2003: 123; Armas and Víquez, 2010: 10; Palacios-Vargas and Reddell, 2013: 52; Palacios-Vargas et al., 2015: 32.

Type Material: Schizomus bartolo: MEXICO: Nuevo León: Municipio de Santa Catarina: Gruta de San Bartolo, 10 mi. SW Monterrey, 21.vi.1969, S. and J. Peck, holotype đ, paratype ? $(\mathrm{AMNH})$.

Additional Material Examined: MEXICO: Nuevo León: Municipio de Santa Catarina: Gruta de San Bartolo, 10 mi. SW Monterrey, ix.1971, T. Raines, 2 \&, 2 imm. (AMNH), 29. iii.2018, M. de Luna-González, 1 subad. 우, 1 imm. (CNAN DNA-Sz268).

\section{Schizophyxia lukensi (Rowland, 1973), comb. nov.}

Schizomus lukensi Rowland, 1973c: 136-138, figs. 1, 4; 1975a: 34, 166-169, 174-177, 214, $215,218,219,222,223,228,229,366-369$, 394, map 5, figs. 160, 173, 191, 192, 292 (part, all records except Cueva de los Cuarteles); 1975a: 19, 20; Dumitresco, 1977: 157; Rowland and Reddell, 1977: 80, 83-85, 98, fig. 2 ; 1979a: 163; 1980: 1, 2, 4, 5, 7-10, 15, 19, figs. 1, 7, 20, 38; Reddell, 1981: 16, 39, 128, 129, 321, 324, fig. 23; Reddell and Cokendolpher, 1995: 5, 104, 107.

Stenochrus lukensi: Reddell and Cokendolpher, 1991: 18; 1995: 5, 12, 18, 101, 102, 107;

Vázquez-Rojas, 1995: 34; 1996: 65; Ruíz and Coronado, 2002: 67; Harvey, 2003: 124;

Palacios-Vargas and Reddell, 2013: 52; Palacios-Vargas et al., 2015: 32.

Type Material: Schizomus lukensi: MEXICO: Tamaulipas: Municipio de Gomez Farias: Cueva del Agua, $30 \mathrm{mi}$. SW Soto la Marina, 31.x.1970, W. Russell, G. and J. Ediger, holotype

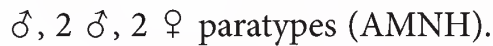

Additional Material Examined: MEXICO: Tamaulipas: Municipio de Gomez Farias: Cueva de los Alvarez, 2302'43"N 99 09'32"W, 335 m, 20. iv.2016, Q. Arreguin, G. Contreras, J. Cruz, D. Guerrero, R. Monjaraz, and G. Montiel, $5 \delta, 5$ 우 (CNAN DNA-Sz116), 1 imm. (AMCC [LP 14513]); Afuera de la Cueva de Ojo de Agua, $23^{\circ} 02^{\prime} 15^{\prime \prime} \mathrm{N}$ 99 $07^{\prime} 45^{\prime \prime} \mathrm{W}, 129$ m, 23.iv.2016, Q. Arreguin, G. Contreras, J. Cruz, D. Guerrero, R. Monjaraz, and G. Montiel, 3 ô, 5 ㅇ (CNAN DNA-Sz118), 1 đิ, 1 
imm. (AMCC [LP 14515]); Sótano del Ojital, $23^{\circ} 03^{\prime} 11^{\prime \prime} \mathrm{N} 117^{\circ} 07^{\prime} 49^{\prime \prime} \mathrm{W}, 252 \mathrm{~m}, 23 . x i .2005$, P. Sprouse, 1 o, 1 으 (CNAN Sz25).

Stenochrus Chamberlin, 1922

Figures 5, 6, 7H, 9E, 10C, 13H, 14D, 20B, 23DF, 24D-F, 25A, B; tables 1,4

Stenochrus: Chamberlin, 1922: 11; Mello-Leitão, 1931: 19; Giltay, 1935: 6, 8; Werner, 1935: 334, 468, 469, 479, 480; Gertsch, 1940: 1; Takashima, 1941: 93; Petrunkevitch, 1945: 322; Takashima, 1947: 33; 1948: 99; Millot, 1948: 154; 1949: 559; Pierce, 1950: 102; 1951: 40; Cloudsley-Thompson, 1958: 122, 214; Savory, 1964: 155; Cloudsley-Thompson, 1968: 152; Levi and Levi, 1968: 122, 469; Shimojana, 1972: 100; Aoki, 1973: 197; Rowland, 1973b: 197, 200; Brignoli, 1974: 145; Rowland, 1975b: 25; Rowland and Reddell, 1977: 83; Savory, 1977: 140; Ribera, 1986: 106; Reddell and Cokendolpher, 1991: 18-19; Cokendolpher and Reddell, 1992: 39; Harvey, 1992: 78; Armas, 1995: 11; Reddell and Cokendolpher, 1995: 101; VázquezRojas, 1996: 63, 65; Armas and Teruel, 1998: 47; Tourinho and Kury, 1999: 2, 5; Armas and Cokendolpher, 2001: 3, 4; Armas, 2002: 3, 6; Armas and Abud-Antun, 2002: 11; Armas and Teruel, 2002: 45; Teruel and Armas, 2002: 91, 92; Harvey, 2003: 123; Teruel, 2003: 40, 42, 66; Armas, 2004: 20; Armas and Colmenares-García, 2006: 27; Cutler and McCutchen, 2006: 263; Shultz, 2007: 224, 228, 245, 247, 249, 251; Teruel, 2007: 51; Villarreal et al., 2008: 67; Armas and Cruz-López, 2009: 20, 21; Armas and Teruel, 2009: 449; Korenko et al., 2009: 1; Montaño-Moreno and Francke, 2009: 33; Armas, 2010a: 55; 2010b: 205, 209, 211, 220; Armas and Víquez, 2010: 9, 10, 12, 18, 20; Krüger and Dunlop, 2010: 47, 49, 52; Armas, 2011: 18; Armas and Teruel, 2011: 335; Armas and Delgado-Santa, 2012: 139,
142; Monjaraz-Ruedas, 2012: 63, 64; Moreno-González and Villarreal, 2012: 73-76; Reddell, 2012: 788; Villarreal and García, 2012: 1, 5; Delgado-Santa and Armas, 2013: 37, 44; Moreno-González et al., 2014: 2, 21, 22; Palacios-Vargas et al., 2015: 8, 32; Villarreal et al., 2014: 371; Monjaraz-Ruedas and Francke, 2015: 452, 454; Souza and Lira, 2015: 766; Monjaraz-Ruedas and Francke, 2016: 782, 783, 789-791, 797; Monjaraz-Ruedas et al., 2016: 120, 126, 131; Villarreal et al., 2016: 24; Beron, 2017: 49; Clouse et al., 2017: 11; Monjaraz-Ruedas and Francke, 2017: 1, 2, 6, 10, 13; MorenoGonzález and Villarreal, 2017: 2; Teruel, 2017a: 46; Monjaraz-Ruedas and Francke, 2018: 189-191, 195, 203, 205, 210-212. Schizomus pecki group (part): Rowland 1975b: $37,39,135,137,167,168,188,209,232$, $233,236,238,241,246,248,250,252,255$, $320,321,348-350,376,390,396,397$; Rowland and Reddell, 1979a: 165, 171; 1979b: 90, 107; 1980: 1, 3, 22-26, 28, 29, 31; Reddell, 1981: 126; Rowland and Reddell, 1981: 19, 20; Cokendolpher and Reddell 1984b: 242; Reddell and Cokendolpher, 1986: 34, 37; Camilo and Cokendolpher, 1988: 53; Reddell and Cokendolpher, 1991: 1, 3; 1995: 101-103; Monjaraz-Ruedas and Francke, 2015: 452; 2016: 781, 783; 2018: 189, 212.

TyPe Species: Stenochrus portoricensis Chamberlin, 1922, by original designation.

Diagnosis: The species of Stenochrus are very conservative morphologically and some are troglomorphic. As in most genera of the order, Stenochrus may be separated from other hubbardiid genera by a combination of characters, as follows. Cheliceral movable finger smooth (fig. 12A); single guard tooth at end of serrula; setal group G3 with G3-4 setae situated posteriorly, except in Stenochrus alcalai Monjaraz-Ruedas and Francke, 2018, and Stenochrus pecki (Rowland, 1973) (fig. 13H). Propeltidium anterior process with two ante- 
rior setae (one posterior to the other) and two pairs of dorsosubmedian setae (fig. 11B); corneate eyes absent. Metapeltidium entire. Tegument without clavate setae. Pedipalps heteromorphic (as in Stenochrus chimalapas Monjaraz-Ruedas and Francke, 2018, and Stenochrus gruta Monjaraz-Ruedas and Francke, 2018), with femur, patella and tibia elongated; trochanter with small mesal spur and without apical process (except in S. alcalai and $S$. gruta) with an acute apical process and a bump, respectively) (fig. $7 \mathrm{H}$ ); femur $F v 1$ and $F v_{2}$ setae acuminate (except in $S$. pecki, with spiniform setae), $F_{v r_{1-3}}$ setae present; patella with three acuminate $P e$ setae and three or four feathered $P m$ setae; tibial setal formula 3-3-4 (Ter-Tmr-Tir) (except S. alcalai with 3-35) (fig. 14D). Leg IV femur anterodorsal margin produced at ca. $90^{\circ}$ angle. Opisthosomal tergite II with one pair of setae $(D m)$. Opisthosomal segments IX-XII not elongated; XII (ठ) without posterodorsal process. Pygidial flagellum $(\hat{o})$ dorsoventrally compressed, cordate or elliptical, with dorsosubmedian medial depression, always associated with pair of closely adjacenr pits (figs. 20B, 23D-F); flagellum ( $q$ ) with two annuli (fig. 24D-F). Spermathecae ( $q$ ) with two pairs of lobes; lateral lobes smaller than (ca. half the length) and same width as median lobes, with apex directed laterally (figs. 9E, 10C); median lobes curved along entire length (parenthesis shaped) or curved apically (inverse J-shaped), with apex directed laterally, usually sclerotized medially to apically (fig. 10C); lobes without bulbs; median lobe bases posterior to lateral lobe bases (figs. 9E, 10C), with duct openings in both pairs of lobes; chitinized arch bowlshaped, base widened, with slightly visible anterior branch, curved and not fused medially, lateral tips wide and sclerotized; gonopod wide and short.

COMPARISONS: Species of Stenochrus resemble species of Nahual, gen. nov., in the elliptical shape of the male pygidial flagellum and the presence of pits on its dorsal surface. However, a medial depression is present in the male flagellum and a small lamella absent on the cheliceral movable finger in Stenochrus (fig. 20), which are absent and present, respectively, in Nahual. Additionally, the pedipalp setae are acuminate setiform in Stenochrus, but spiniform in Nahual.

Stenochrus resembles Baalrog, gen. nov., in the shape of the female spermathecae, in which the lateral lobes are reduced. However, the lateral lobes are the same width and the median lobes markedly curved in Stenochrus, whereas the lateral lobes are narrower than the median lobes, which are only slightly curved apically, in Baalrog.

InCLUded SPeCies: Stenochrus alcalai Monjaraz-Ruedas and Francke, 2018; Stenochrus chimalapas Monjaraz-Ruedas and Francke, 2018; Stenochrus gruta Monjaraz-Ruedas and Francke, 2018; Stenochrus guatemalensis (Chamberlin, 1922); Stenochrus leon Armas, 1995; Stenochrus pecki (Rowland, 1973a); Stenochrus portoricensis Chamberlin, 1922.

Distribution: Species of Stenochrus inhabit tropical Central America and the Caribbean islands. All records reported for S. portoricensis are applicable to the genus, however, expanding its distribution to Europe (Clouse et al., 2017). Ongoing research on this widely distributed species, including phylogenetic analyses in preparation, suggests that the genus is endemic to the Caribbean and Central America, with multiple introductions into Europe from different sources (fig. 5).

Natural History: Although species of Stenochrus are primarily cavernicolous, some, notably $S$. portoricensis, are epigean and cavernicoulus, and usually found under large rocks. Some populations of $S$. portoricensis occur in dry, disturbed, or unnatural habitats, e.g., in greenhouses or associated with human waste, suggesting this species may be tolerant of desiccation and perturbation. Physiological tolerance together with parthenogenesis may explain its ability to successfully colonize new habitats over a large area.

REMARKs: The presence of elongated pedipalps is dimorphic among conspecific males of some 

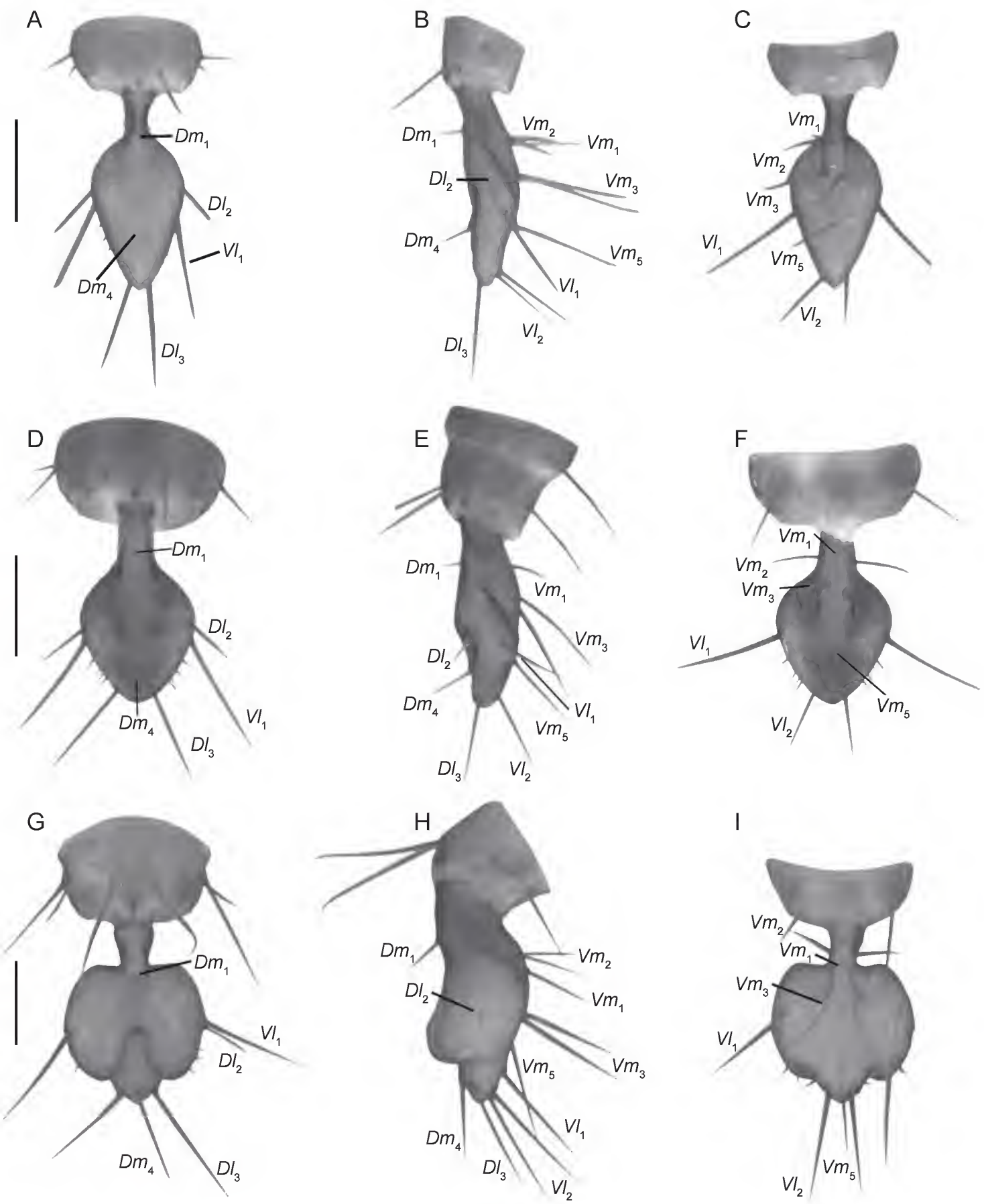

FIG. 23. Short-tailed whipscorpions (Schizomida: Hubbardiidae Cook, 1899), pygidial flagellum, dorsal (A, D, G), lateral (B, E, H) and ventral (C, F, I) views. A-C. Schizophyxia lukensi (Rowland, 1973), comb. nov., o (CNAN Sz25). D-F. Stenochrus gruta Monjaraz-Ruedas and Francke, 2018, ð (CNAN T1155). G-I. Troglostenochrus valdezi (Monjaraz-Ruedas, 2012), comb. nov., ồ (CNAN T698). Scale bars $=0.2 \mathrm{~mm}$. 
A
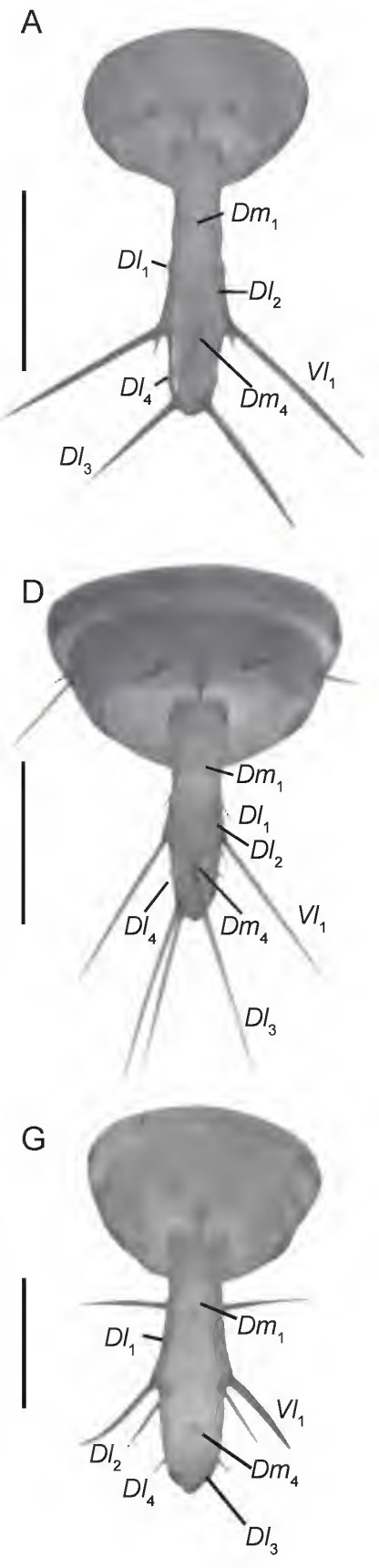

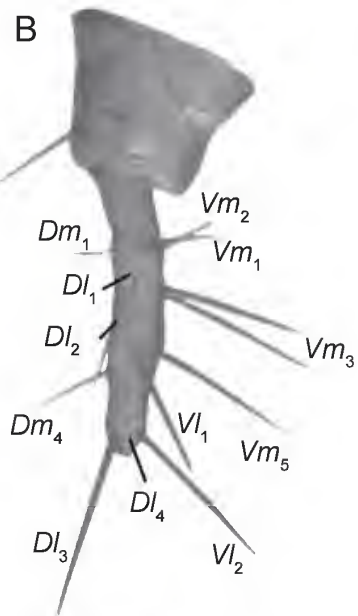

C
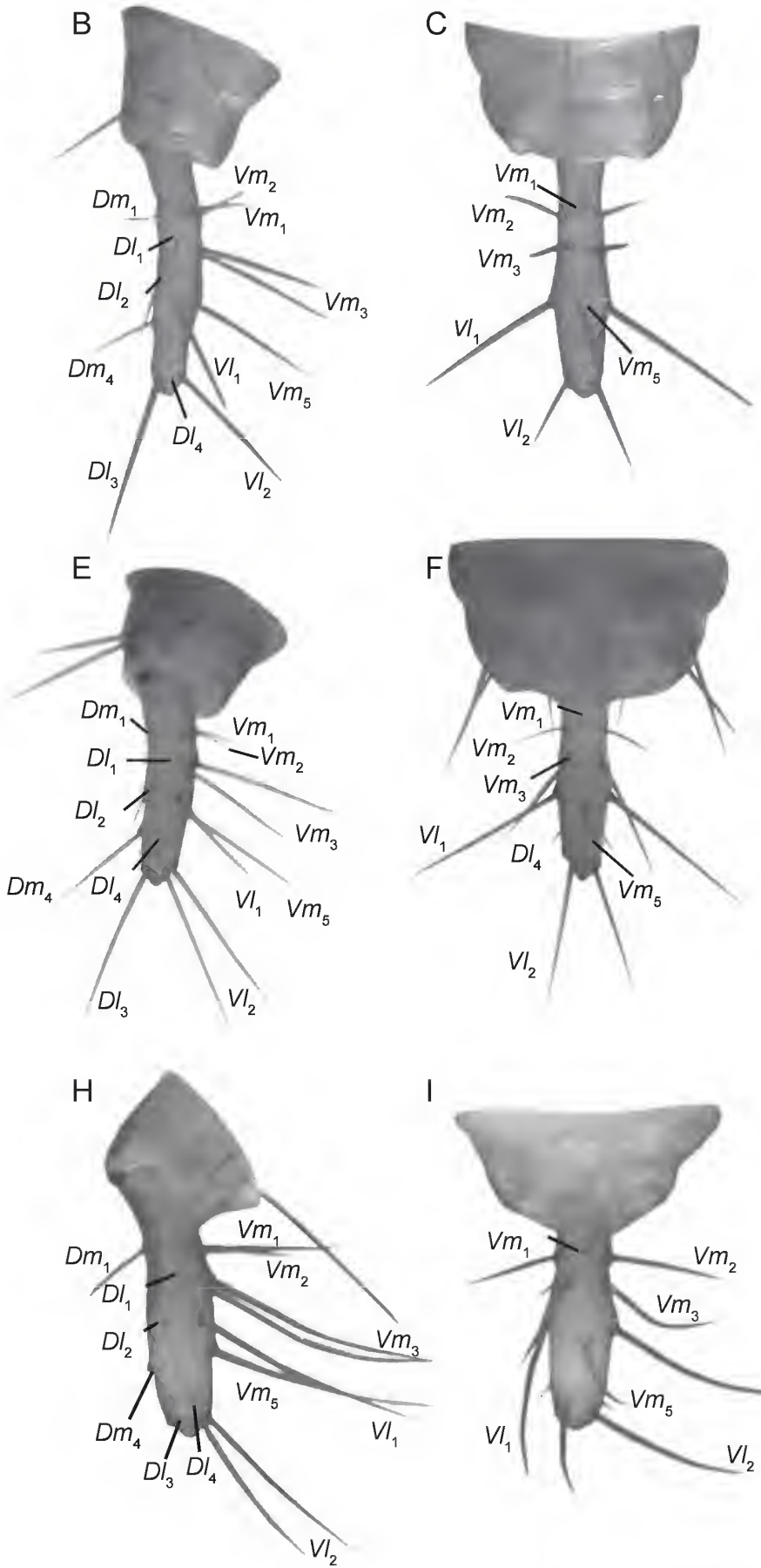

।

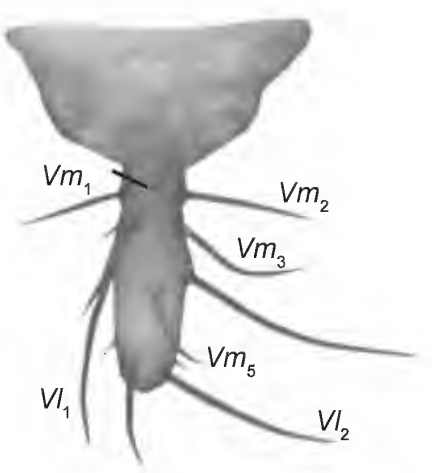

FIG. 24. Short-tailed whipscorpions (Schizomida: Hubbardiidae Cook, 1899), pygidial flagellum, dorsal (A, D, G), lateral (B, E, H) and ventral (C, F, I) views. A-C. Schizophyxia lukensi (Rowland, 1973), comb. nov., q (CNAN Sz25). D-F. Stenochrus gruta Monjaraz-Ruedas and Francke, 2018, 9 (CNAN T1156). G-I. Troglostenochrus valdezi (Monjaraz-Ruedas, 2012), comb. nov., + (CNAN T699). Scale bars $=0.2 \mathrm{~mm}$. 
Stenochrus species. Pedipalp elongation results in modification of the apical process of the trochanter, as observed in S. gruta and S. pecki.

Stenochrus guatemalensis was assigned to the genus based on two pairs of dorsal setae on the propeltidium and female spermathecae with the lateral lobes reduced and the medial lobes apically sclerotized. Unfortunately, the precise type locality for $S$. guatemalensis is unknown and several attempts to collect it in Guatemala were unsuccessful.

The types and only known specimens of $S$. leon, deposited in Cuba, were not examined in the present study and the brief and poorly illustrated original description does not provide the level of detail required to accurately place it within the genera recognized herein. The species may belong to another genus because the lateral lobes of the female spermathecae are slightly shorter (i.e., less than $1 / 3$ the length of the median lobes) than those of other species of Stenochrus. A detailed examination of the chelicerae and female spermathecae and/or DNA sequence data are needed to verify its generic placement. The species is retained within Stenochrus until additional evidence proves otherwise.

Monjaraz-Ruedas and Francke (2018) stated that $S$. alcalai bears three pairs of dorsal setae on the propeltidium, but after thorough reexamination the species was observed to bear only two pairs, consistent with the diagnosis of Stenochrus.

\section{Stenochrus alcalai Monjaraz-Ruedas and Francke, 2018}

Stenochrus alcalai Monjaraz-Ruedas and Francke, 2018: 203-206, 208, figs. 43-56, 71.

Type Material: MEXICO: Oaxaca: Municipio de San Pedro Jocotipac: La Laguna, $17^{\circ} 43^{\prime} 38^{\prime \prime} \mathrm{N} 97^{\circ} 06^{\prime} 06^{\prime \prime} \mathrm{W}, 2402 \mathrm{~m}$, 23.viii.2015, D. Barrales, J. Cruz, O. Francke, R. Monjaraz, and J. Sánchez, holotype ô (CNAN T1160), paratype o (CNAN T1161); El Tanque, $17^{\circ} 44^{\prime} 35^{\prime \prime} \mathrm{N}$ $97^{\circ} 06^{\prime} 20^{\prime \prime} \mathrm{W}, 2402 \mathrm{~m}, 22 . v i i i .2016$, D. Barrales, J. Cruz, O. Francke, R. Monjaraz, and J. Sánchez, 2 ô, 1 ㅇ paratypes (CNAN T1162).

\section{Stenochrus chimalapas Monjaraz-Ruedas and Francke, 2018}

Stenochrus chimalapas Monjaraz-Ruedas and Francke, 2018: 191-194, 203, 212, figs. 1-14, 71.

Type Material: MEXICO: Oaxaca: Municipio de Santa María Chimalapas: Cueva de Escolapa, $16^{\circ} 51^{\prime} 02^{\prime \prime} \mathrm{N} 94^{\circ} 44^{\prime} 53^{\prime \prime} \mathrm{W}, 219 \mathrm{~m}$, 25.x.2016, E. Briones, A. Juárez, A. Valdez, and J. Valerdi, holotype $\delta$ (CNAN T1152), 1 đิ, 2 ㅇ paratypes (CNAN T1153).

Additional Material Examined: MEXICO: Oaxaca: Municipio de Santa María Chimalapas: Cueva de Escolapa, $16^{\circ} 51^{\prime} 02^{\prime \prime} \mathrm{N}$ $94^{\circ} 44^{\prime} 53^{\prime \prime} \mathrm{W}, 219 \mathrm{~m}, 28 . i i i .2010$, J. Cruz, O. Francke, C. Santibañez and A. Valdez, 2 to (CNAN T1154), 25.x.2016, E. Briones, A. Juárez, A. Valdez, and J. Valerdi, $2 \mathrm{imm}$. (AMCC [LP 14533]).

\section{Stenochrus gruta Monjaraz-Ruedas and Francke, 2018}

Stenochrus gruta Monjaraz-Ruedas and Francke, 2018: 190, 195-198, 2012, figs. 15-28, 71.

Type Material: MEXICO: Oaxaca: Municipio de Sola de Vega: San Sebastián de las Grutas, Gruta de San Sebastián, 16 $37^{\prime} 09^{\prime \prime} \mathrm{N}$ $96^{\circ} 58^{\prime} 49^{\prime \prime} \mathrm{W}, 1623$ m, 1.vii.2013, G. Contreras, J. Cruz, J. Mendoza, C. Santibáñez, and A. Valdez,

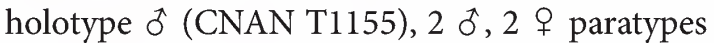
(CNAN T1156).

Additional Material Examined: MEXICO: Oaxaca: Municipio de Sola de Vega: San Sebastián de las Grutas, Gruta de San Sebastián, $16^{\circ} 37^{\prime} 09^{\prime \prime} \mathrm{N} 96^{\circ} 58^{\prime} 49^{\prime \prime} \mathrm{W}, 1623 \mathrm{~m}, 20 . v i i .2006$, O. Francke, H. Montaño, C. Santibañez, A. Valdez, and G. Villegas, 10 ㅇ (CNAN Sz199), 1.vii.2013, G. Contreras, J. Cruz, J. Mendoza, C. Santibáñez, and A. Valdez, 1 q , 1 imm. (AMCC [LP 14492]). 
Stenochrus pecki (Rowland, 1973)

Schizomus pecki Rowland, 1973a: 6, 7, 16, 19-23, figs. 17-19; 1973c: 136; 1975a: 34, 135, 167, $168,188,209,232,234,240-244,246,247$, 250-253, map 4, figs. 216, 218, 221, 231; Dumitresco, 1977: 157; Rowland and Reddell, 1977: 80, 83, 84, 88, 96, 98, 99, fig. 2; 1979a: 163; 1979b: 104; 1980: 1, 16, 23-26, 29-32, figs. 63, 64, 66, 69, 79; Reddell, 1981: $16,51,126,128,129,320,324$, fig. 23; Cokendolpher and Reddell, 1984b: 242; Reddell and Cokendolpher, 1986: 36; Camilo and Cokendolpher, 1988: 53; Reddell and Cokendolpher, 1995: 5, 109.

Stenochrus pecki: Reddell and Cokendolpher, 1991: 18; 1995: 5, 9, 12, 18, 102, 103, 109; Vázquez-Rojas, 1995: 34; 1996: 65; Harvey, 2003: 125; Armas, 2004: 51; Armas and Cruz-López, 2009: 23; Zawierucha et al., 2013: 359; Palacios-Vargas and Reddell, 2013: 52; Palacios-Vargas et al., 2015: 32; Monjaraz-Ruedas and Francke, 2016: 783, 784, 804, fig. 2C, D; Monjaraz-Ruedas et al., 2017: 102, 103, figs. 3C, D, 4G, H; Monjaraz-Ruedas and Francke, 2018: 203.

Type Material: Schizomus pecki: MEXICO: Tabasco: Municipio de Teapa: Grutas de Cocona, 2 mi. NE Teapa, 1.viii.1948, C. Goodnight, holotype $\delta$ (AMNH), 29 November 1971, O. McKenzie, paratype $q(\mathrm{AMNH})$.

Additional Material Examined: MEXICO: Tabasco: Municipio de Teapa: Grutas de Cocona, $2 \mathrm{mi}$. NE Teapa, $17^{\circ} 33^{\prime} 49^{\prime \prime} \mathrm{N}$ $92^{\circ} 55^{\prime} 44^{\prime \prime} \mathrm{W}, 27 \mathrm{~m}, 20$ xii.2011, G. Contreras, E. Goyer, E. Hijmensen, and J. Mendoza, 1 ô, 1 (CNAN Sz35).

Stenochrus portoricensis Chamberlin, 1922

Stenochrus portoricensis Chamberlin, 1922: 11, 12; Mello-Leitão, 1931: 19; Giltay, 1935: 8; Werner, 1935: 469; Takashima, 1941: 93; Bücherl, 1971: 382; Rowland, 1973b: 195,
197, 200; Brignoli, 1974: 145; Rowland, 1975b: 31, 186; Rowland and Reddell, 1977: 83; 1980: 14; Martín and Oromí, 1984: 267; Camilo and Cokendolpher, 1988: 55; Reddell and Cokendolpher, 1991: 3, 18; Muchmore, 1993: 33; 1993: 33; Humphreys, 1995: 178, fig. 4a, b; Baert et al., 1996: 16, fig. 8, map 5; Reddell and Cokendolpher, 1995: 2, $4-8,10-12,18,19,50,92,98,99,101-103$, 110, 111, 156, fig. 79; Vázquez Rojas, 1995: 33; 1996: 65; Tourinho and Kury, 1999: 1, 3-5, figs. 1-4; Cokendolpher and Reddell, 2000: 187; Giribet and Ribera, 2000: 207; Armas, 2001: 53, 58, fig. 4A-D; Armas and Cokendolpher, 2001: 3, 4; Armas, 2002: 3, 5, 8; Armas and Abdun-Antun, 2002: 14; Giribet et al., 2002: 14, 62; Ruíz and Coronado, 2002: 67; Harvey, 2003: 125; Teruel, 2003: 39, 46, 47, 59, 66-68, fig. 49; Armas, 2004: $3,4,7,10,11,16,17,20,51$, fig. 21A-C; Pérez and Teruel, 2004: 168, 172, 175, 176, figs. 9, 13; Teruel, 2004: 36, 40, 41, fig. 19; Wallberg et al., 2004: 571; Zonstein, 2004: fig. 12; Armas, 2005: 3; Teruel and Armas, 2005: 129, 132, fig. 5; Armas, 2006: 240; Harvey, 2006: 173; Spanga and Gillespie, 2006: 559; Klompen et al., 2007: 940; Harvey et al., 2008: 168; Pérez-Gelabert, 2008: 68; Santos et al., 2008: 1, 2, 5-7, figs. 7-9; Armas and Cruz-López, 2009: 20; Korenko et al., 2009: 1, 2, figs. 1-4; Santos and Pintoda-Rocha, 2009: 42; Teruel and Infante, 2009: 386, 388-390, fig. 4; Armas, 2010b: 211, 218, 219; Armas and Víquez, 2010: 9 , 18, 20; Armas et al., 2010: 499, 500; Dabert et al., 2010: 227; Krüger and Dunlop, 2010: 49; Kury et al., 2010: 568; Pepato et al., 2010: 5; Regier et al., 2010: 1080, fig. 1; Armas and Teruel, 2011: 335; Nedvěd et al., 2011: 539, 544, 546; Ortuño and MartínezPérez, 2011: 244; Armas and Delgado-Santa, 2012: 183, 185, fig. 2; Monjaraz-Ruedas, 2012: 64; Moreno-González and Villarreal, 2012: 62, 73; Teruel, 2012: 39, 40; Teruel et 
al., 2012: 97, 102, 104, 107, 110, 111, fig. 16; Villarreal and García, 2012: 1, 4; Armas, 2013: 93, 93; Christophoryová et al., 2013: $25,27,28$, figs. 2A, B, 3A-E, 4A-E; Delgado-Santa and Armas, 2013: 37; He et al., 2013: 10; Santos et al., 2013: 1; Zawierucha et al., 2013: 357-360, fig. 1-3; Alegre Barroso and Barba Díaz, 2014: 54; Armas, 2014: 37; Barranco et al., 2014: 295, 296, 298, 300, fig. 3; Moreno-González et al., 2014: 22; Armas and Melic, 2015: 4, 5, fig. 15A-G; Armas and Rehfeldt, 2015: 55, 59, 60, fig. 16; Gallão et al., 2015: 1, 2, fig. 1, 3A-C; Guzmán et al., 2015: 478; Huber et al., 2015: 52; Monjaraz-Ruedas and Francke, 2015: 456, 461, 475; Palacios-Vargas et al., 2015: 32; Souza and Lira, 2015: 766, 767, fig. 1; Cabezas-Cruz et al., 2016: 307; Giupponi et al., 2016: 31; Monjaraz-Ruedas and Francke, 2016: 801; Monjaraz-Ruedas et al., 2016: 119, fig. 4E, F; Talanda, 2016: 281; Armas et al., 2017: 542; Beron, 2017: 37, 47, 49; Clouse et al., 2017: 5, 11, figs. 2-4; DelfínGonzález et al., 2017: 283, 284; MonjarazRuedas and Francke, 2017: 399, 407; Ruiz and Valente, 2017: 89, 91; Šestáková et al., 2017: 19; Teruel, 2017a: 41, 45; 2017b: 81; Armas, 2018: 81, 87; Giupponi et al., 2018: 200-203, fig. 20A; Monjaraz-Ruedas and Francke, 2018: 189-191, 197, 212.

Schizomus antilus Hilton, 1933: 91, 92; Giltay, 1935: 6; Takashima, 1941: 94; Rowland, 1975b: 32, 186; Rowland and Reddell, 1977: 87; 1979a: 162; 1980: 2, 14; Armas and Alayón García, 1984: 9, 10; Camilo and Cokendolpher, 1988: 55; Armas, 1989a: 1, 23; Reddell and Cokendolpher, 1995: 98.

Schizomus cavernicolens Chamberlin and Ivie, 1938: 102, 103, figs. 4-7; Gertsch, 1940: 4; Takashima, 1941: 94; Pearse, 1945: 153; Cárdenas-Figueroa, 1950: 154; Rémy, 1961: 406; Nicholas, 1962: 181; Vandel, 1964: 116; 1965: 93; Reddell, 1971: 28; Rowland, 1971a: 117; 1973c: 135; Brignoli, 1974: 149; Row- land, 1975b: 186; Reddell, 1977: 230; Rowland and Reddell, 1977: 87; 1980: 14; Camilo and Cokendolpher, 1988: 55; Reddell and Cokendolpher, 1995: 110.

Schizomus portarricensis: Bolívar and Pieltain, 1944: 301 (lapsus calami).

Schizomus latipes: Cloudsley-Thompson, 1949: 261 [misidentification]; 1958: 123 (misidentification); Rémy, 1961: 407 (part, Cambridgeshire record only); Cloudsley-Thompson, 1968: 153, 154 (misidentification); Rowland and Reddell, 1977: 87 [misidentification].

Schizomus floridanus Muma, 1967: 18-20, unnumbered map, figs. 13-15; Rowland, 1971b: 304; 1973c: 135; 1975b: 186, 187; Brach, 1976: 97-99, figs. 1-3; Rowland and Reddell, 1977: 87; Gertsch, 1979: 21; Rowland and Reddell, 1980: 14; Borror et al., 1981: 123; Levi, 1982: pl. 94; Camilo and Cokendolpher, 1988: 55; Vine et al., 1988: 29; Borror et al., 1989: 107; Humphreys et al., 1989: 185, 189; Reddell and Cokendolpher, 1995: 5, 99, 110, 111.

Schizomus longimanus Rowland, 1971a: 119, 120, 124, 125, figs. 4-6, 17; Brignoli, 1973: 6-9, figs. 1, 2; Reddell, 1973: 38; Rowland, 1973a: 13, 16, 22, fig. 21; 1973c: 135, 137; Brignoli, 1974: 143, 144, 146, 147, 151, fig. 1b; Sbordoni et al., 1974: 19; Rowland, 1975b: 186; 1975b: 14, 15, 17, 19, 20; Dumitresco, 1977: 157; Rowland and Reddell, 1977: 87; 1980: 14; Camilo and Cokendolpher, 1988: 55; Armas, 1989a: 23; Reddell and Cokendolpher, 1995: 5, 99, 110, 111.

Schizomus portoricensis: Rowland, 1973b: 197; Peck, 1974: 19; 1975: 307; Rowland, 1975b: $18,25,32,76,137,166-169,185-206,214-$ $219,224,225,366-369,376,377,379,383$, 396, 397, map 5, figs. 161, 167-170, 181, 199-206, 292; Beck et al., 1976: 8; Reddell, 1977: 230; Rowland and Reddell, 1977: 79, 80, 81, 87-97, figs. 4-18; 1979a: 162, 165, 194; 1979b: 107; 1980: 1, 2, 4, 5, 7, 11, 13, 

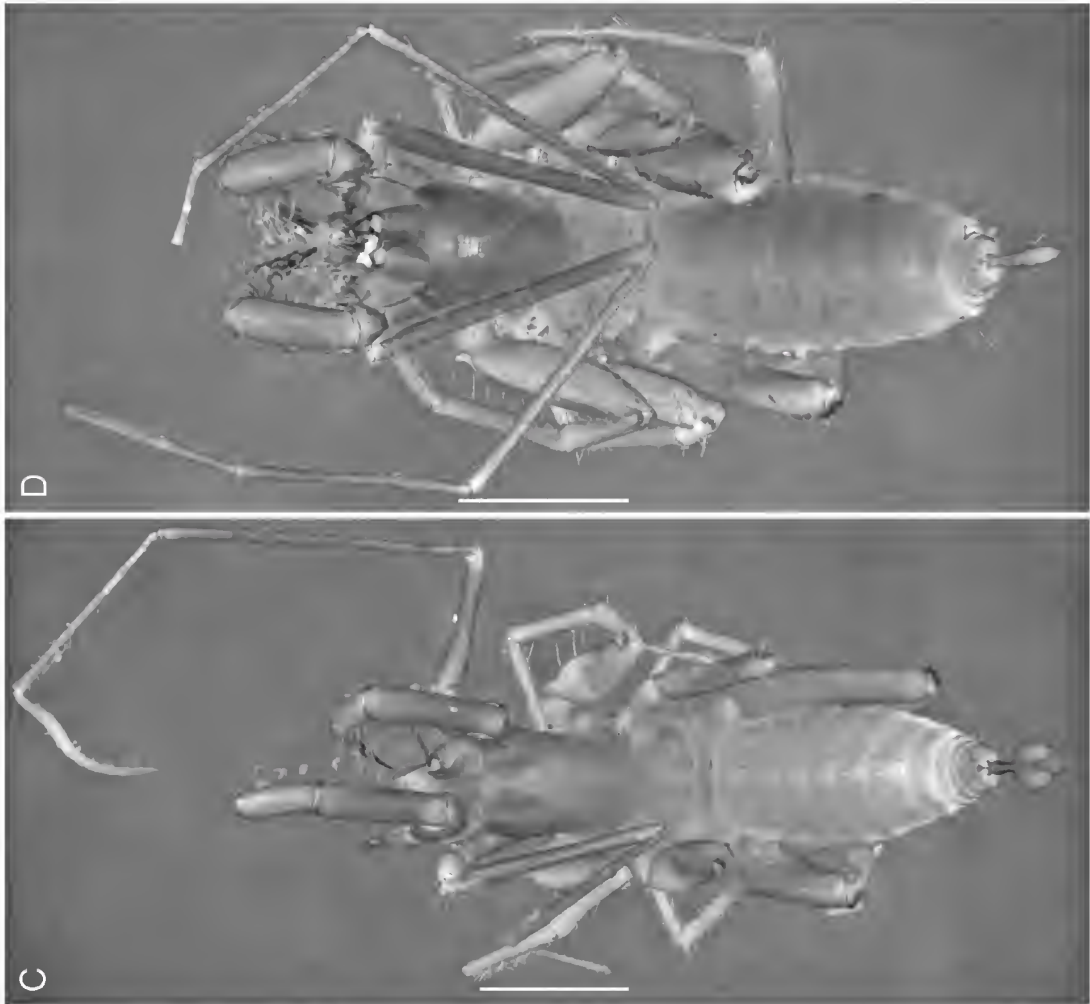

몽

冚 :

$\stackrel{\Xi}{\approx}$

نे

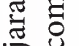

응

$\sum \stackrel{\sim}{*}$

is

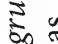

के प्रै

竞㘼

ป

离.

๑

$<$

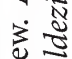

.

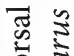

음

कิ รัง

苟

द्व

it

के

$\stackrel{-1}{-1}$

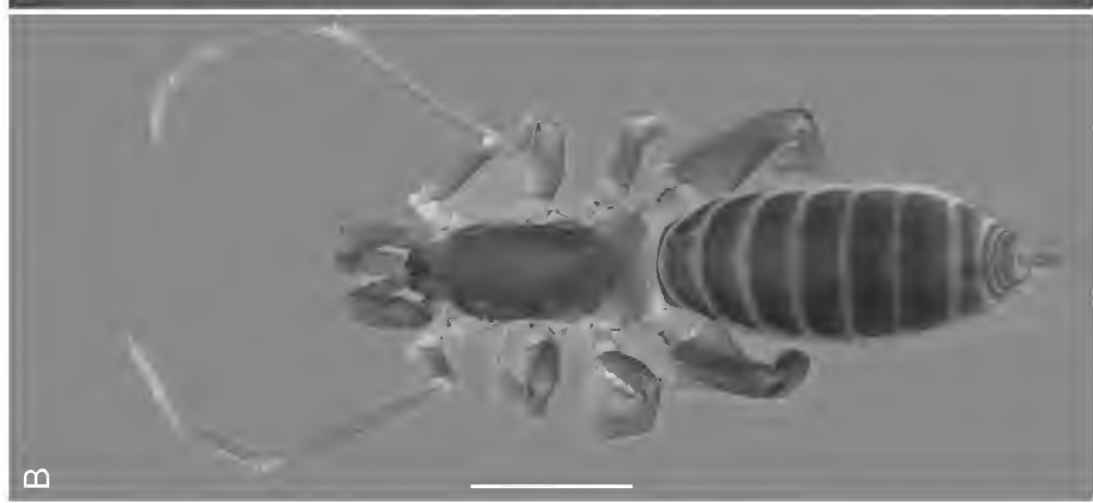

등

ن in

F

青

要

을

豆品

,

चाI

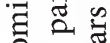

응

궁

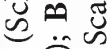

苜

의

남

品

率艺

$3 \cup 0$

D ro ot

焉文

$\ddot{\infty} \ddot{\infty}$ क्षे ठำ क त ปู่

는

记 
14-16, 20, figs. 1, 6, 14-17, 28, 46-53; Sket and Iliffe, 1980: 873; Peck, 1981: 72; Reddell, 1981: 42, 50, 55-59, 68, 126, 127, fig. 22; Martín and Oromí, 1984: 265-270, fig. 2; Reddell and Cokendolpher, 1984: 173, 175; Martín et al., 1985: 40, 41, 43-45; Peck and Kukalova-Peck, 1986: 165; Reddell and Cokendolpher, 1986: 31-33; Ribera, 1986: 106, fig. 66; Camilo and Cokendolpher, 1988: 52-58, figs. 1, 6, 7; Armas, 1989a: 1, 2, 9, 23, 24, 34; 1989b: 3; Armas and Abud-Antun, 1990: 1, 5, 14-16, 19, figs. 7, 9; Peck, 1990: 368, 369; Oromi and Martín, 1992: 536; Peck, 1993: 42; Baert and Mahnert, 2015: 3 , 15-17, 70-73, map 5, fig. 3.

Schizomus loreto Armas, 1977: 5-8, figs. 3, 4; 1984: 9; 1989a: 1, 23; Reddell and Cokendolpher, 1995: 110.

Type Material Examined: Schizomus floridanus: U.S.A.: Florida: Dade County: Ross and Castellow Hammock, $1 q$ holotype (AMNH). Schizomus longimanus: MEXICO: Chiapas: Municipio de Tuxtla Gutierrez: Cueva Cerro Hueco, 3 km SE Tuxtla Guitierrez, 18.viii.1967, J. Reddell, J. Fish, and M. Tandy, holotype $\delta$ (AMNH), paratype $\delta$ (AMNH), $2 q$ paratypes (AMNH).

Material Examined: BELIZE: Cayo District: Belmopan, 2 \& (AMNH); Blue Hole National Park, $17^{\circ} 08^{\prime} 49^{\prime \prime} \mathrm{N} 88^{\circ} 40^{\prime} 29^{\prime \prime} \mathrm{W}, 170 \mathrm{~m}$, 6.xi.2013, R. Monjaraz and C. Santibañez, 1 q (CNAN DNA-Sz197); Caves Branch, Buck's Bypass Cave, 1 \& (AMNH); Hummingbird Highway, 1 ㅇ (AMNH). COLOMBIA: Quindío Department: Montenegro, Finca Hotel Bosque Nativo, $04^{\circ} 33^{\prime} 10^{\prime \prime} \mathrm{N} 75^{\circ} 45^{\prime} 32^{\prime \prime} \mathrm{W}, 1250$ m, 10. xii.2011, A. Valdez 1 \& (CNAN Sz40). DOMINICAN REPUBLIC: La Altagracia Province: near Alto de Chavon, $18^{\circ} 29^{\prime} 27^{\prime \prime} \mathrm{N}$ $68^{\circ} 55^{\prime} 04^{\prime \prime} \mathrm{W}, 65.5 \mathrm{~m}, 15 . v i i .2004$, J. Huff and E.S. Volschenk forested road cutting in cane fields, $1 \mathrm{imm}$. (AMCC [LP 3750]). GUATEMALA: Alta Verapaz, Coban, Reserva Natural Chahunpek, $16^{\circ} 00^{\prime} 35^{\prime \prime} \mathrm{N} 90^{\circ} 38^{\prime} 56^{\prime \prime} \mathrm{W}, 230 \mathrm{~m}$, 20.viii.2017, D. Barrales and R. Monjaraz 1 q (AMCC [LP 14554]); Santa Rosa, El Papayo, $14^{\circ} 08^{\prime} 17^{\prime \prime} \mathrm{N} 90^{\circ} 33^{\prime} 52^{\prime \prime} \mathrm{W}, 296 \mathrm{~m}, 3-4$ July 2006 , C. Avila, R. Estrada, J. Huff, D. Ortíz, and C. Víquez, 2 ㅇ (AMCC [LP 6014]); Izabal, Río Sauce, $15 \mathrm{~km}$ E of El Estor, picnic area on river, $15^{\circ} 33^{\prime} 37^{\prime \prime} \mathrm{N} 89^{\circ} 17^{\prime} 06^{\prime \prime} \mathrm{W}, 13 \mathrm{~m}, 7 . v i i .2006$, J. Huff, D. Ortíz, and C. Víquez, 2 \& (AMCC [LP 6016]). HONDURAS: Santa Barbara Departament: Municipio de Santa Barbara: San Antonio, $1 \mathrm{~km}$ NE Río Grande de Otoro, $14^{\circ} 46^{\prime} 28^{\prime \prime} \mathrm{N}$ $88^{\circ} 10^{\prime} 15^{\prime \prime} \mathrm{W}, 355 \mathrm{~m}, 28 . i x .2008$, M. Branstetter and C. Víquez, 1 \& (AMCC [LP 9475]). Municipio de Santa Rita: Desvio a Santa Rita, 3.4 km SW San Francisco de Ojuera, side of road,

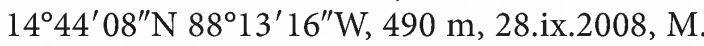
Branstetter and C. Víquez, 1 (AMCC [LP 9473]). Lempira Departament: Municipio de La Iguala: La Telegrafía, side of road going to Gracias, before reaching Santa Rita, $14^{\circ} 45^{\prime} 58^{\prime \prime} \mathrm{N}$ $88^{\circ} 14^{\prime} 31^{\prime \prime} \mathrm{W}, 466 \mathrm{~m}, 28 . i x .2008$, M. Branstetter and C. Víquez, 2 o (AMCC [LP 9474]). JAMAICA: St. Ann Parish: Falling Cave, Douglas Castle, 1 \& (AMNH). Trelawny Parish: Ulster Spring, ca. $1 \mathrm{~km} \mathrm{~N}, 18^{\circ} 20^{\prime} 39^{\prime \prime} \mathrm{N}$ $77^{\circ} 30^{\prime} 47^{\prime \prime} \mathrm{W}, 420 \mathrm{~m}$, 18.vi.2005, S. Huber, 1 ㅇ (AMCC [LP 5179]). MEXICO: Campeche: Municipio de Calakmul: Reserva Ejidal Ley de Fomento Agropecuario, $3.5 \mathrm{~km}$ from Cristobal Colon, $17^{\circ} 59^{\prime} 13^{\prime \prime} \mathrm{N} 89^{\circ} 24^{\prime} 54^{\prime \prime} \mathrm{W}, 243 \mathrm{~m}$, 14.x.2011, D. Barrales, D. Candia, O. Francke, G. Montiel, and A. Valdez, 10 \& (CNAN Sz50); outside Cueva de Balam-kú (Volcán de los

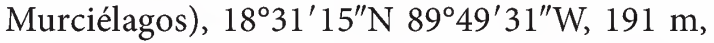
12.x.2011, D. Barrales, D. Candia, O. Francke, G. Montiel, and A. Valdez, 5 \& (CNAN Sz51). Chiapas: Municipio de Cacahuatan: Bridge Faja de Oro, $15^{\circ} 02^{\prime} 20^{\prime \prime} \mathrm{N} 92^{\circ} 10^{\prime} 17^{\prime \prime} \mathrm{W}, 658 \mathrm{~m}, 6$. xii.2015, G. Contreras, H. Montaño, and L. Olguin, 1 우 (CNAN DNA-Sz125), 7.iii.2017, J. Cruz, G. Contreras, J. Mendoza, and L. Olguín, 2 ㅇ (AMCC [LP 14546]). Municipio de Marquez de Comillas: Playón de la Gloria, trail Rockera, $16^{\circ} 09^{\prime} 01^{\prime \prime} \mathrm{N} 90^{\circ} 50^{\prime} 47^{\prime \prime} \mathrm{W}, 150 \mathrm{~m}$, 13.xii.2014, G. Contreras and L. Olguín, 1 
(CNAN Sz159). Municipio de Ocosingo: Arroyo Nayte, Sierra la Cojolita, $16^{\circ} 47^{\prime} 39^{\prime \prime} \mathrm{N}$ $91^{\circ} 02^{\prime} 32^{\prime \prime} \mathrm{W}, 194 \mathrm{~m}, 18 . x .2006$, J. Ballesteros, O. Francke, H. Montaño, and A. Valdez. 1 o, 3 우 (CNAN Sz10), 28.vii.2013, O. Francke, J. Mendoza, R. Monjaraz, C. Santibañez, A. Valdez, and K. Zárate, 4 o , 4 ㅇ (CNAN Sz93); El Aserradero $16^{\circ} 47^{\prime} 07^{\prime \prime} \mathrm{N} 91^{\circ} 02^{\prime} 17^{\prime \prime} \mathrm{W}, 205 \mathrm{~m}, 18 . x$. 2006, J. Ballesteros, O. Francke, H. Montaño, and A. Valdez, 37 ㅇ (CNAN Sz11), 28.vii.2013, O. Francke, J. Mendoza, R. Monjaraz, C. Santibañez, A. Valdez, and K. Zárate, 35 ㅇ (CNAN Sz108); El Carton, $5 \mathrm{~km}$ W Frontera Corozal, $16^{\circ} 47^{\prime} 11^{\prime \prime} \mathrm{N} 90^{\circ} 55^{\prime} 41^{\prime \prime} \mathrm{W}, 153 \mathrm{~m}$, 6.ix. 2005, M. Cordoba, O. Francke, A. Jaimes, H. Montaño, and A. Valdez, 30 ㅇ (CNAN Sz15); Cueva Grande, reserva Chan-Kin, $16^{\circ} 41^{\prime} 29^{\prime \prime} \mathrm{N}$ $90^{\circ} 49^{\prime} 26^{\prime \prime} \mathrm{W}, 144 \mathrm{~m}, 19 . x .2006$, C. Ballesteros, O. Francke, H. Montaño and A. Valdez, 3 q (CNAN Sz16); Frontera Benemerito, $10 \mathrm{~km}$ from junction, $16^{\circ} 43^{\prime} 21^{\prime \prime} \mathrm{N} 90^{\circ} 55^{\prime} 29^{\prime \prime} \mathrm{W}, 162 \mathrm{~m}$, 20.x. 2006, C. Ballesteros, O. Francke, H. Montaño, and A. Valdez, 2 (CNAN Sz19). Municipio de Ocozocuautla: Cueva de los Bordos, $16^{\circ} 49^{\prime} 46^{\prime \prime} \mathrm{N} 93^{\circ} 31^{\prime} 32^{\prime \prime} \mathrm{W}, 615 \mathrm{~m}, 14 . i v .2014, \mathrm{O}$. Sanchez and K. Zárate, $1 \delta$ (CNAN DNASz24). Municipio de San Fernando: Cueva de la Cañada, Ejido Benito Juárez, 16 $53^{\prime} 50^{\prime \prime} \mathrm{N}$ $93^{\circ} 07^{\prime} 59^{\prime \prime} \mathrm{W}, 926 \mathrm{~m}$, 3.vii.2014, K. Zárate, 1 ๙ (CNAN Sz158); Cueva del Guano, $16^{\circ} 48^{\prime} 50^{\prime \prime} \mathrm{N}$ $93^{\circ} 10^{\prime} 19^{\prime \prime} \mathrm{W}, 840 \mathrm{~m}, 2 . i v .2014, \mathrm{G}$. Contreras and G. Montiel, 2 우 (CNAN Sz185); Cueva de la Mano, Ejido Miguel Hidalgo, $16^{\circ} 51^{\prime} 52^{\prime \prime} \mathrm{N}$ $93^{\circ} 14^{\prime} 52^{\prime \prime} \mathrm{W}, 1043 \mathrm{~m}, 18 . v i .2011$, G. Contreras, J. Cruz, O. Francke, R. Monjaraz, C. Santibañez, A. Valdez, and K. Zárate, 6 o, 6 ㅇ (CNAN Sz2); Cueva de Las Abejas, $16^{\circ} 50^{\prime} 55^{\prime \prime} \mathrm{N}$ $93^{\circ} 14^{\prime} 36^{\prime \prime} \mathrm{W}, 1190 \mathrm{~m}, 19 . v i .2011$, G. Contreras, J. Cruz, O. Francke, R. Monjaraz, C. Santibañez, A. Valdez, and K. Zárate, 1 o, 5 (CNAN Sz3). Municipio de Tuxtla Gutierrez: Tuxtla Gutierrez, $16^{\circ} 46^{\prime} 27^{\prime \prime} \mathrm{N} 93^{\circ} 08^{\prime} 02^{\prime \prime} \mathrm{W}, 652 \mathrm{~m}$, 4.viii.2006, PBN, 1 ơ (CNAN Sz89). Colima: Municipio de Villa de Alvarez: Manantial Agua Fria, $19^{\circ} 16^{\prime} 23^{\prime \prime} \mathrm{N} 103^{\circ} 52^{\prime} 40^{\prime \prime} \mathrm{W}, 458 \mathrm{~m}, 23$. vi.2014, G. Contreras and G. Montiel, 1 웅
(CNAN DNA-Sz63). Guerrero: Municipio de Chilpancingo: Cueva del Borrego, Omiltemi, $17^{\circ} 33^{\prime} 19^{\prime \prime} \mathrm{N} 99^{\circ} 39^{\prime} 17^{\prime \prime} \mathrm{W}, 1997$ m, 21 September 2012, G. Contreras, J. Cruz, J. Mendoza, and D. Ortíz, $1 \mathrm{imm}$. (CNAN Sz94), 1 q (AMCC [LP 14498]). Jalisco: Municipio de Puerto Vallarta: Calle Olas Altas, $20^{\circ} 35^{\prime} 56^{\prime \prime} \mathrm{N} 105^{\circ} 14^{\prime} 14^{\prime \prime} \mathrm{W}, 32$ m, 21.ii. 2015, G. Contreras, 3 ㅇ (AMCC [LP 14505]). Nayarit: Municipio de San Blas: Cueva del Naranjo, $21^{\circ} 28^{\prime} 46^{\prime \prime} \mathrm{N} 105^{\circ} 04^{\prime} 39^{\prime \prime} \mathrm{W}, 580 \mathrm{~m}$, 17.vi. 2015, G. Contreras and G. Montiel, 4 우 (CNAN Sz177). Tabasco: Municipio de Macuspana: outside Cueva de Agua Blanca, $17^{\circ} 37^{\prime} 12^{\prime \prime} \mathrm{N} 92^{\circ} 28^{\prime} 12^{\prime \prime} \mathrm{W}, 193$ m, 30.ix.2014, G. Contreras and G. Montiel, 2 ㅇ (CNAN Sz180). Quintana Roo: Municipio de Bacalar: Bacalar Lake, $18^{\circ} 38^{\prime} 51^{\prime \prime} \mathrm{N} 88^{\circ} 24^{\prime} 46^{\prime \prime} \mathrm{W}, 3 \mathrm{~m}$, 13.vii.2014, G. Contreras, H. Montaño, G. Montiel, R. Paredes, and A. Valdez, 3 ô, 3 (CNAN Sz174). Yucatan: Municipio de Chichén Itzá: Actún Xkyc (Xkyc Cave), Calcehtok, 1 ㅇ (AMNH); Cenote Seco (Dry Cenote), 1 ô, 1 \& (AMNH); Ruinas de Chichenitza, $20^{\circ} 40^{\prime} 49^{\prime \prime} \mathrm{N} 88^{\circ} 34^{\prime} 10^{\prime \prime} \mathrm{W}$, $32 \mathrm{~m}$, 1.viii.2014, J. Mendoza and R. Monjaraz, 2 oิ, 2 ㅇ (CNAN Sz168), 3 \& (AMCC [LP 14506]). Municipio de Merida: Km 172 highway Merida-Cancun, $20^{\circ} 45^{\prime} 49^{\prime \prime} \mathrm{N} 88^{\circ} 03^{\prime} 25^{\prime \prime} \mathrm{W}$, 36 m, 20.vii.2010, D. Barrales, G. Contreras, J. Cruz, O. Francke, G. Montiel, M. Paradiz, and C. Santibañez, 4 ㅇ (CNAN Sz23). Municipio de Tecax: Cueva Chocantes, $20^{\circ} 13^{\prime} 28^{\prime \prime} \mathrm{N}$ $89^{\circ} 17^{\prime} 58^{\prime \prime} \mathrm{W}, 91 \mathrm{~m}, 2 . x .2014$, G. Contreras and G. Montiel, 1 o, 1 ㅇ (CNAN Sz165). Municipio de Tecoh: Grutas de Tzabna, $20^{\circ} 43^{\prime} 49^{\prime \prime} \mathrm{N}$ $89^{\circ} 28^{\prime} 29^{\prime \prime} \mathrm{W}, 23 \mathrm{~m}, 3 . x .2014, \mathrm{G}$. Contreras and G. Montiel, 3 ㅇ (CNAN Sz164). U.S.A: Florida: Dade County: Everglades National Park, 4 imm. (AMNH); Florida City, 3.2-8 km S, 14 우 (AMNH); Homestead, W Mowry St., 1 (AMNH); Matheson Hammock, 22 ㅇ (AMNH); Miami, 1 o (AMNH); Miami Brickell Hammock, 1 ㅇ (AMNH); Royal Palm State Park, 1 \& (AMNH). Monroe County: Marathon, 2 (AMNH); Stock Island, 1 (AMNH). Puerto Rico: Bosque Estatal Susua, old campsite, trail leading into forest, 
$18^{\circ} 04^{\prime} 03^{\prime \prime} \mathrm{N} 66^{\circ} 53^{\prime} 50^{\prime \prime} \mathrm{W}, 181 \mathrm{~m}, 19-20 . x .2009$, J. Huff and L. Prendini 1 ㅇ (AMCC [LP 10149]); Cueva de los Alferos, Barrio Moza, near Isabela, 2 \& (AMNH); Cueva Tuna, 3.5 $\mathrm{km} \mathrm{S}$ of Cabo Rojo, 1 o, 3 ㅇ, $1 \mathrm{imm}$. (AMNH).

Troglostenochrus, gen. nov.

Figures 4, 6, 7I, 9F, 13I, 23G-I, 24G-I, 25C, D; tables 1,4

Stenochrus (part): Monjaraz-Ruedas, 2012: 63, 64; Monjaraz-Ruedas and Francke, 2018: $189,192$.

Type Species: Stenochrus valdezi MonjarazRuedas, 2012 [= Troglostenochrus valdezi (Monjaraz-Ruedas, 2012), comb. nov.], type species, here designated.

Diagnosis: Troglostenochrus, gen. nov., may be separated from other hubbardiid genera by the following combination of characters. Cheliceral movable finger serrate, with multiple teeth; single guard tooth at end of serrula; setal group G3 with G3-3 setae situated anteriorly (fig. 13I). Propeltidium anterior process with two anterior setae (one posterior to the other) and three pairs of dorsosubmedian setae (fig. 11A); corneate eyes absent. Metapeltidium entire. Tegument without clavate setae. Pedipalps homeomorphic; trochanter with mesal spur, apical process long, projected and fan-shaped (fig. 7I); femur $F v_{1}$ and $F v_{2}$ setae spiniform, $F v r_{1-4}$ setae present $\left(F v r_{1-3}\right.$ setae in Troglostenochrus palaciosi (Reddell and Cokendolpher, 1986), comb. nov.); patella with four acuminate $P e$ setae and four feathered $P m$ setae; tibia setal formula 3-3-4 (Ter-Tmr-Tir) (fig. 14D). Leg IV femur anterodorsal margin produced at ca. $90^{\circ}$ angle. Opisthosomal tergite II with one pair of setae $(\mathrm{Dm})$. Opisthosomal segments IX-XII not elongated; XII ( $\widehat{)}$ ) without posterodorsal process. Pygidial flagellum $(\overleftarrow{\sigma})$ bulbous, trilobed, without dorsal depressions (fig. 23G-I), with pair of dorsosubmedian, rounded projections; flagellum $(q)$ with two annuli (fig. 24G-I). Spermathecae ( + ) with two pairs of lobes; lateral lobes ca. 3/4 the length of median lobes, linear, with apex directed laterally; median lobes inverse J-shaped with apex directed laterally; lobes unsclerotized apically and without bulbs; median lobe bases anterior to lateral lobe bases, with duct openings along entire length (fig. 9F); chitinized arch hastate, with curved anterior branch, and lateral tips extremely projected and tapering; gonopod long and narrow.

Comparisons: Species of Troglostenochrus, gen. nov., resemble species of Cokendolpherius Armas, 2002 in the trilobed pygidial flagellum and robust pedipalps, with a projected, conical apical process of the pedipalp trochanter, of the male, and the three pygidial flagellomeres and horizontal bracket shape of the chitinized arch of the spermathecae, of the female. However, Troglostenochrus bears three pairs of dorsal setae on the propeltidium, whereas Cokendolpherius bears two pairs, and females of Troglostenochrus possess both $\mathrm{Vm}_{2}$ and $\mathrm{Dl}_{4}$ setal pairs on the pygidial flagellum, which are absent in Cokendolpherius, and the spermathecal lobes are considerably longer in Troglostenochrus than in Cokendolpherius.

Species of Troglostenochrus resemble species of Baalrog, gen. nov., in the shape of the female spermathecae, in which the lateral lobes are reduced, and the lateral tips projected. However, the lateral lobes are considerably longer and wider in Troglostenochrus than in Baalrog, and the anterior branches of the chitinized arch are present and curved in Troglostenochrus, but absent in Baalrog.

EтYMology: The generic name is a compound word derived from troglo (Greek, "hole"), referring to the troglomorphic species included in the genus, and "Stenochrus," the genus in which its two species were formerly accommodated. It is masculine in gender.

INCLUded SPeCIEs: Troglostenochrus palaciosi (Reddell and Cokendolpher, 1986), comb. nov.; Troglostenochrus valdezi (Monjaraz-Ruedas, 2012), comb. nov.

Distribution: Troglostenochrus, gen. nov., is known from only two disjunct localities in the 
states of Guerrero and Chiapas, southern Mexico. Presumably, the genus extends across the entire Sierra Madre del Sur in Oaxaca and the Sierra Chiapas, although extensive searching in the caves of Chiapas have thus far failed to collect additional species (fig. 4).

Natural History: The known species of Troglostenochrus, gen. nov., are strictly cavernicolous, inhabiting the dark zone of caves, and have not been collected on the surface. Mayazomus loobil Monjaraz-Ruedas and Francke, 2015, was collected outside the cave inhabited by $T$. valdezi, comb. nov.

Remarks: Species of Troglostenochrus, gen. nov., closely resemble species of Cokendolpherius, endemic to Cuba. Unfortunately, no samples of Cokendolpherius were available for DNA isolation and attempts to collect fresh material of $T$. palaciosi, comb. nov., were unsuccessful (the cave was never found). Nevertheless, the morphological characters and simultaneous phylogenetic analyses (fig. 6) unequivocally support the placement of T. palaciosi within Troglostenochrus. The acquisition and analysis of DNA sequence data from Cokendolpherius are needed to test its relationship to Troglostenochrus.

\section{Troglostenochrus palaciosi (Reddell and Cokendolpher, 1986), comb. nov.}

Schizomus mexicanus: Palacios-Vargas, 1981: 64 [misidentification]; Alberti and PalaciosVargas, 1987: 2 [misidentification].

Schizomus sp. nov.: Hoffmann et al., 1986: 151, 208, 238.

Schizomus palaciosi Reddell and Cokendolpher, 1986: 31, 35-37, figs. 1-5, 11; Alberti and Palacios-Vargas, 1987: 1-14, figs. 1-30; Alberti, 1990: 29; Ludwig and Alberti, 1990: 255-257, figs. 1, 10; Palacios-Vargas, 1990: 5; Reddell and Cokendolpher, 1995: 6, 109; Alberti, 2000: 313, figs. 3d, 7b; Giribet et al., 2002: 49.

Stenochrus palaciosi: Reddell and Cokendolpher, 1991: 18; 1995: 6, 8, 12, 18, 103, 108, 109;
Vázquez-Rojas, 1995: 33; 1996: 65; Harvey, 2003: 124; Moreno-González and Villarreal, 2012: 73; Monjaraz-Ruedas, 2012: 65; Palacios-Vargas and Reddell, 2013: 52; Zawierucha et al., 2013: 359; Palacios-Vargas et al., 2015: 32.

Type Material: Schizomus palaciosi: MEXICO: Guerrero: Municipio de Taxco de Alarcón: Gruta de Acuitlapan, $12 \mathrm{~km}$ NE of Taxco, 26.v.1978, J. Palacios, holotype ô (CNAN T120), 23.v.1980, J. Palacios, paratype $q$ (CNAN T119).

\section{Troglostenochrus valdezi}

(Monjaraz-Ruedas, 2012), comb. nov.

Stenochrus valdezi Monjaraz-Ruedas, 2012:

63-68, figs. 1-9; Moreno-González and Villarreal, 2012: 73; Palacios-Vargas and Reddell, 2013: 52; Palacios-Vargas et al., 2015: 32; Monjaraz-Ruedas and Francke, 2018: 189, 192.

Type Material: Stenochrus valdezi: MEXICO: Chiapas: Municipio de La Trinitaria: Cueva de San Francisco, $16^{\circ} 05^{\prime} 59^{\prime \prime} \mathrm{N} 92^{\circ} 02^{\prime} 49^{\prime \prime} \mathrm{W}, 1546$ m, 18.vi.2011, G. Contreras, J. Cruz, O. Francke, R. Monjaraz, C. Santibañez, A. Valdez, and K. Zárate, holotype $\delta$ (CNAN T698), 4 ㅇ paratypes (CNAN T699).

Additional Material Examined: MEXICO: Chiapas: Municipio de La Trinitaria: Cueva de San Francisco, 16 $05^{\prime} 59^{\prime \prime} \mathrm{N} 92^{\circ} 02^{\prime} 49^{\prime \prime} \mathrm{W}, 1546$ m, 18.vi.2011, G. Contreras, J. Cruz, O. Francke, R. Monjaraz, C. Santibañez, A. Valdez, and K. Zárate, 3 (CNAN Sz160), 1 q , 1 imm. (AMCC [LP 14532]), O. Francke, J. Mendoza, R. Monjaraz, C. Santibañez, A. Valdez, and K. Zárate, 26.vi. 2013, 1 §, 3 우 (CNAN Sz92).

\section{DISCUSSION}

Until quite recently, the systematics of Schizomida focused principally on the description of new genera and species, using a limited set of morphological character systems (Rowland, 
1975b; Reddell and Cokendolpher, 1995; Harvey, 2003; Monjaraz-Ruedas and Francke, 2015, 2016, 2017). The shapes of the male pygidial flagellum and the female spermathecae were emphasized for the diagnosis and delimitation of schizomid species. Although these character systems are very informative at the species level, because they are sexually selected, they are often unreliable for the diagnosis and delimitation of supraspecific taxa within the order, for the same reason (Reddell and Cokendolpher, 1995; Monjaraz-Ruedas and Francke, 2016; Villarreal et al., 2008). The relief of the dorsal surface of the flagellum and the relative positions of its setae are more informative phylogenetically than flagellar shape per se (Cokendolpher and Reddell, 1992; Harvey, 1992; Monjaraz-Ruedas et al., 2016); however, there is considerable homoplasy in these characters as well (Monjaraz-Ruedas et al., 2016).

Although a few genera, e.g., Mayazomus, Surazomus, and Tayos Reddell and Cokendolpher, 1995, are diagnosed by autapomorphies, the diagnosis of most schizomid genera currently requires a combination of homoplastic characters, 20 of which were listed by Reddell and Cokendolpher (1995): coronate ocelli; tegument clavate setae; cheliceral movable finger accessory teeth and/or lamella; movable finger serrula guard teeth; pedipalps sexual dimorphism (heteromorphic or homeomorphic) and male dimorphism (or polymorphism); pedipalp armature; pedipalp trochanter mesal spur development; trochanter anterior process setation; leg IV femur, anterodorsal margin development; metapeltidium divided or entire; opisthosomal elongation; opisthosomal segment II setation; opisthosomal segment XII, posterodorsal process; male pygidial flagellum dorsoventrally or laterally compressed; flagellum dorsal surface pits; female pygidial flagellum, number of flagellomeres or annuli; gonopod structure; female spermathecae, number of lobes; spermathecal lobes nodular or without nodules.

Recent investigations of other character systems, such as the counts and relative positions of setae on the chelicerae and pedipalps and a more detailed and precise description of the diverse structures comprising the female spermathecae, offered new potential for schizomid systematics at the species level and above (Moreno-González et al., 2014; Monjaraz-Ruedas et al., 2016, 2017; Villarreal et al., 2016). However, only the annuli on the female flagellum have thus far been tested in a phylogenetic framework (Monjaraz-Ruedas et al., 2016). The phylogenetic information content of other character systems, and their utility for schizomid systematics above the species level, were untested prior to the analyses of Monjaraz et al. (in prep.). Based on those results, a brief assessment is provided below.

Propeltidial Setae: The number of pairs of setae on the dorsal surface of the propeltidium was introduced as a character by Rowland (1975b), who hypothesized that reduction in the number was synapomorphic in Hubbardiidae because four or more pairs are observed in Protoschizomidae. Rowland (1975b) noted this character was highly variable within the species groups subsequently described by Rowland and Reddell (1979a, 1979b, $1980,1981)$ and that three pairs was the most common condition among New World hubbardiids. However, among Mexican schizomids, two, three, or four pairs of propeltidial setae, combined with characters of the chelicerae movable finger, the male pygidial flagellum, and the female spermathecae, proved effective for generic diagnosis in the present study. The number of pairs of propeltidial setae was constant among congeners, e.g., Harveyus, gen. nov., and Stenochrus each bear two pairs of setae, Nahual, gen. nov., and Schyzophyxia, gen. nov., each bear three, and Heteroschizomus, stat. rev., bears four. Furthermore, the number of pairs of propeltidial setae (and the relief of the cheliceral movable finger) are independent of sex and stage, permitting immatures of both sexes to be reliably identified to genus. Based on these observations, the utility of the propeltidial setae for the generic diagnosis of schizomids appears to have been underestimated.

Pedipalp Tibial Setae: Monjaraz-Ruedas and Francke (2016) proposed the use of pedipalp setae for species delimitation and subsequently 
homologized the pedipalp setae of Hubbardiidae with those of Protoschizomidae (Monjaraz-Ruedas et al., 2017), demonstrating that the number and shape of these setae are informative for the diagnosis of schizomid families. Although all hubbardiids possess a similar setal configuration, especially on the pedipalp femur and patella, variation in setal patterns on the pedipalp tibia is informative at the generic level. The tibia bears three rows of setae, the retrolateral (Ter), median (Tmr), and prolateral (Tir) rows, which may be transformed into a formula by counting the number of setae in each (Ter-Tmr-Tir). In the present study, the formula of tibial setae was usually constant among congeners. For example, formulae of 5-5-6 and 3-3-4 occur in Nahual and Stenochrus, respectively, providing a diagnostic difference between them. Furthermore, as with the number of propeltidial setae, this character is independent of sex and stage, permitting immatures of both sexes to be reliably identified to genus. When used in combination, these characters reliably diagnose genera in which one is constant. For example, although Stenochrus and Schizophyxia share the tibial setae formula 3-3-4, Schizophyxia bears three pairs of propeltidial setae whereas Stenochrus bears two.

Male Pygidial Flagellum: The shape of the male pygidial flagellum was traditionally considered the most important character for species delimitation in schizomids (Reddell and Cokendolpher, 1995). However, the character is problematic for generic diagnosis for the same reason it is useful for species delimitation: sexual selection on flagellar shape has created considerable variation at the species level (Reddell and Cokendolpher, 1995; Villarreal et al., 2008), which obfuscates homology assessment and hinders the definition of character states. The coding and definition of the states of male flagellar shape could be improved by avoiding subjective assessments and quantitatively comparing homologous components of the flagellum using ratios or shape analysis with geometric morphometrics, which can then be analyzed phylogenetically as continuous characters (De Bivort et al., 2009;
Magalhães and Santos, 2012), as recently applied to Mayazomus (Monjaraz-Ruedas and Francke, 2016). A more objective, quantitative characterization of flagellar shape may assist with generic diagnosis across the order and provide phylogenetically informative data as, e.g., in Heteroschizomus, which possess a distinctly elongated flagellum. This approach may also reveal homoplasy or mistaken homology assessment as, e.g., with the elongated pygidial flagellum of Nahual lanceolatus, comb. nov., and Heteroschizomus, a character that led Rowland and Reddell (1981) to assign these taxa to the same species group.

Although there are problems with using male flagellar shape as a character for generic diagnosis in schizomids, other characters of the male flagellum offer potential for the purpose. The relief of the dorsal surface of the flagellum, despite also exhibiting considerable variation, is constant or nearly so among some congeners, e.g., all known species of Nahual, which possess a pair of dorsosubmedian pits, and most species of Rowlandius, which exhibit a pair of submedian projections. The relative positions of the flagellar setae also appear to provide reliable characters for species delimitation in some genera, e.g., Piaroa, but exhibit considerable interspecific variation, limiting their utility for generic diagnosis beyond specific cases, e.g., in differentiating Calima Moreno-Gonzalez and Villarreal, 2012, and Piaroa from other South American genera.

Female Spermathecae: Brignoli (1973) introduced female spermathecal shape as a character for species delimitation, but Rowland and Reddell (1979a, 1979b, 1980, 1981) noted it could not be used in isolation, due to the conserved morphology of the spermatheca, suggesting these authors were aware that the character is often constant among congeners. Despite these concerns, spermathecal shape continues to be used for species delimitation and as an aid to identify females in the absence of males. This practice probably leads to erroneous delimitation and identification, especially among the many species complexes and parthenogenetic populations of schizomids. For this reason, characters 
of the female spermathecae should be used with caution and species descriptions should be based on their component structures, rather than solely on the general shape. In the present study, subdivision of the spermatheca into its components facilitated the identification of several characters (i.e., shape and size of the chitinized arch, relative lengths and widths of the median and lateral lobes, relative positions of the medial and lateral lobe bases, orientation of the lobe apex, and apical sclerotization or bulbs on the lobes), the combination of which was constant among congeners, permitting reliable diagnosis of genera. Some of these characters also vary interspecifically, providing information at the species level.

Phylogenetic hypotheses of DNA sequences, analysed separately and simultaneously with the morphological characters, greatly assisted the identification of monophyletic groups, defined as genera in the present contribution, and the morphological characters for their diagnosis, by optimization on the preferred phylogenetic hypothesis. Based on this assessment, characters of the female spermathecae presented herein were found to be reasonably reliable for generic recognition.

In conclusion, the integration of morphological and molecular data not only increased knowledge of the schizomid diversity in the New World but disentangled what was once considered a homoplastic and variable morphology in a large "catchall" genus (i.e., Stenochrus) into discrete units each diagnosable by unique character combinations.

\section{ACKNOWLEDGMENTS}

The authors are grateful to many people and institutions that contributed to this study. R.M.-R. thanks the Graduate Program in Biological Sciences of the Universidad Nacional Autónoma de México (UNAM); the Consejo Nacional de Ciencia y Tecnología (CONACYT), Mexico, for Scholarship 288690 and financial support for DNA sequencing from Project 271108 'Red temática Código de Barras de la Vida’ (continuidad de redes temáticas); the Instituto de Biología of the Universidad Nacional Autónoma de México (IBUNAM) for infrastructure and logistics; the Richard Gilder Graduate School at the American Museum of Natural History (AMNH) for a Collections Study Grant and a Theodore Roosevelt Memorial Grant, which assisted his visits to the AMNH; and the American Arachnological Society for a grant from the Vincent Roth Fund for Systematic Research, which supported the research. The following people and institutions assisted with fieldwork and/or contributed material used in the study: current and former members of the Colección Nacional de Ácaros (CNAC) and the Colección Nacional de Arácnidos (CNAN) at IBUNAM, especially D. Barrales, G. Contreras, J. Cruz, D. Guerrero, J. Mendoza, G. Montiel, L. Olguín, R. Paredes, C. Santibáñez, and A. Valdez; the Laboratorio de Aracnología, IBUNAM, Tlaxcala (LATLAX); current and former members of the AMNH Arachnology Lab, especially R. Botero-Trujillo, E. González-Santillán, J. Huff, and E.S. Volschenk; J. Palacios (Laboratorio de Microartópodos, FCUNAM); M. de Luna-González (Universidad Autónoma de Nuevo León); and colleagues from other institutions: N. Ángel, J. Bokma, M. Branstetter, V. Garcia-Marquez, A. Gluesenkamp, S. Huber, S. Longhorn, P. Mendez-Acuña, D. Ortíz, F. Pilo-Garcia, D. Rebollo-Salinas, M. Salas-Rod, C. Savvas, P. Sprouse, E. Tinoco, C. Víquez, and K. Zárate. J.-L. Lacaille-Múzquiz and J. Olivos provided help at the Centro Interpretativo Ecológico, Tamaulipas, to Grupo Espeleológico Jaguar and Proyecto Espeleológico Sistema Huautla. J. Reddell and J.C. Cokendolpher loaned material from the Texas Memorial Museum. M. Hedin and S. Derkarabetian (San Diego State University, CA) donated material of Hubbardia pentapeltis Cook, 1899. L. Sorkin and P. Colmenares (AMNH) provided logistical support in the AMNH Collections of Arachnida and Myriapoda, P. Colmenares assisted in the AMNH Molecular Systematics Laboratory of the Sackler Institute for Comparative Genomics, and S. Thurston assisted in the AMNH Division of Invertebrate Zoology. A. Jiménez and 
L. Márquez assisted R.M.-R. with molecular work in the Molecular Laboratory of the Laboratorio Nacional de Biodiversidad (LANABIO) at IBUNAM. B. Mendoza Garfias from Microscopia Electrónica (LANABIO) and J.A. Cruz-López assisted R.M.-R. with scanning electron microscopy, and S. Guzmán Gómez assisted in the Laboratorio de Microscopía y Fotografía de la Biodiversidad (II). H. Ochoterena (IBUNAM) and A. Nieto (FCUNAM) provided invaluable comments and suggestions concerning the project, U. Hernández helped R.M.-R. develop names for new genera and species described in this contribution; M.S. Harvey, P. Ornelas, and J.R. Reddell reviewed previous drafts of the manuscript, and S. Thurston (AMNH) assisted with preparing the plates. Specimens recently collected for this work were obtained under Scientific Collector Permit FAUT-0175 from SEMARNAT to O.F.F. Some of the material examined was collected during National Science Foundation (NSF) grants DEB 0413453 and DEB 0640219 to L.P. DNA sequencing at the AMNH was funded in part by NSF grants EAR 0228699 and DEB 0640219, and a grant from the Richard Lounsbery Foundation, to L.P.

\section{REFERENCES}

Acosta, L.E., A. Pérez-González, and A.L. Tourinho. 2007. Methods for taxonomic study. In R. Pinto-daRocha, G. Machado, and G. Giribet (editors), Harvestmen, the biology of opiliones: 494-500. Cambridge and London: Harvard University Press.

Alberti, G. 1990. Comparative spermatology of Araneae. Acta Zoologica Fennica 190: 17-34.

Alberti, G. 2000. Chelicerata. In B.G.M. Jamieson (editor), Progress in male gamete ultrastructure and phylogeny: 311-388. In K.G. Adiyodi and R.G. Adiyodi (editors), Reproductive biology of invertebrates, vol. 9. New York: Wiley.

Alberti, G., and J.G. Palacios-Vargas. 1987. Fine structure of spermatozoa and spermatogenesis of Schizomus palaciosi, Reddell and Cokendolpher, 1986 (Arachnida: Uropygi, Schizomida). Protoplasma 137: 1-14.

Alegre Barroso, A., and R. Barba Díaz. 2014. Estado de conservación de Jimeneziella decui, una especie cav- ernícola de Cuba (Opiliones: Laniatores). Revista Ibérica de Aracnología 25: 43-57.

Aoki, J. 1973. Soil Zoology: an introduction to classification and ecology of soil animals. Tokyo: Hokyryukan Publishing Company.

Armas, L.F. de. 1977. Dos nuevas especies de Schizomus Arachnida: Schizomida, de Cuba. Poeyana 166: 1-8.

Armas, L.F. de. 1984. Tipos de Arachnida depositados en el Instituto de Zoología de la Academia de Ciencias de Cuba. I. Amblypygi, Opiliones, Ricinulei, Scorpiones, Schizomida, y Uropygi. Poeyana 284: $1-11$.

Armas, L.F. de. 1989a. Adiciones al orden Schizomida (Arachnida) en Cuba. Poeyana 387: 1-45.

Armas, L.F. de. 1989b. Depredación de Schizomus portoricensis (Arachnida: Schizomida) por Phrynus marginemaculatus (Arachnida: Amblypygi). Miscelánea Zoológica, Instituto de Ecología y Sistemática, Academia de Ciencias de Cuba 46: 3.

Armas, L.F. de. 1995. Arácnidos de Nicaragua 5. Nueva especie de Stenochrus (Schizomida: Hubbardiidae). Revista Nicaraguense de Entomología 34: 9-15.

Armas, L.F. de. 2001. Amblypygi, Schizomida, Scorpiones y Solpugida. In M.G. Vazquez (editor), Fauna edáfica de las selvas tropicales de Quintana Roo: 53-59. Quintana Roo, México: Secretaria de Educación Pública.

Armas, L.F. de. 2002. Dos géneros nuevos de Hubbardiidae (Arachnida: Schizomida) de Cuba. Revista Ibérica de Aracnología 5: 3-9.

Armas, L.F. de. 2004. Arácnidos de República Dominicana. Palpigradi, Schizomida, Solifugae y Thelyphonida (Chelicerata: Arachnida). Revista Ibérica de Aracnología 2: 3-63.

Armas, L.F. de. 2005. Los esquizómidos troglobios de Cuba (Archnida: Schizomida). Espelunca Digital 1: $1-7$.

Armas, L.F. de. 2006. Sinopsis de los amblipígidos antillanos (Arachnida: Amblypygi). Boletín de la Sociedad Entomológica Aragonesa 38: 223-245.

Armas, L.F. de. 2010a. Nuevos arácnidos de Puerto Rico (Arachnida: Amblypygi, Araneae, Opiliones, Parasitiformes, Schizomida, Scorpiones). Boletín de la Sociedad Entomológica Aragonesa 47: 55-64.

Armas, L.F. de. 2010b. Schizomida de Sudamérica (Chelicerata: Arachnida). Boletín de la Sociedad Entomológica Aragonesa 46: 203-234.

Armas, L.F. de. 2011. Género nuevo de Hubbardiidae (Arachnida: Schizomida) para Jamaica. Solenodon 9: 12-19. 
Armas, L.F. de. 2013. Pedipalpi (Arachnida: Amblypygi, Schizomida, Thelyphonida) de Cuba Occidental. Revista Ibérica de Aracnología 22: 91-94.

Armas, L.F. de. 2014. Los amblipigios cavernícolas de Cuba (Arachnida: Amblypygi). Revista Ibérica de Aracnología 24: 29-51.

Armas, L.F. de. 2018. Una especie nueva de Luisarmasius del oriente de Cuba y descripción de la hembra de Pinero marmoreus (Schizomida: Hubbardiidae). Revista Ibérica de Aracnología 33: 81-88.

Armas, L.F. de, and A.J. Abud-Antun. 1990. El orden Schizomida (Arachnida) en República Dominicana. Poeyana 393: 1-23.

Armas, L.F. de, and A.J. Abud-Antun. 2002. Tres especies nuevas de Rowlandius (Schizomida: Hubbardiidae) de República Dominicana, Antillas Mayores. Revista Ibérica de Aracnología 5: 11-17.

Armas, L.F. de, and G. Alayón García. 1984. Sinopsis de los arácnidos cavernícolas de Cuba (excepto ácaros). Poeyana 276: 1-25.

Armas, L.F. de, and J.C. Cokendolpher. 2001. Comments on some schizomids from the Dominican Republic, with description of a new species of Rowlandius (Schizomida: Hubbardiidae). Revista Ibérica de Aracnología 3: 3-6.

Armas, L.F. de, and P.A. Colmenares-García. 2006. Nuevo género de Hubbardiidae (Arachnida: Schizomida). Boletín de la Sociedad Entomológica Aragonesa 39: 27-30.

Armas, L.F. de, and J.A. Cruz-López. 2009. Especie nueva de Stenochrus (Schizomida: Hubbardiidae) de Oaxaca, México. Solenodon 8: 20-24.

Armas, L.F. de, and L. Delgado-Santa. 2012. Nuevo género de Hubbardiidae (Arachnida: Schizomida) de la cordillera occidental de los Andes, Colombia. Revista Ibérica de Aracnología 21: 139-143.

Armas, L.F. de, and A. Melic. 2015. Orden Schizomida. Revista Ibero Diversidad Entomológica @ccesible 21: 1-6. Online resource (http://sea-entomologia. org/IDE@/revista_21.pdf).

Armas, L.F. de, and S. Rehfeldt. 2015. Stenochrus portoricensis, Zomus bagnallii and a new genus of schizomids (Schizomida: Hubbardiidae) from a greenhouse in Frankfurt am Main, Germany. Arachnologische Mitteilungen 49: 55-61.

Armas, L.F. de, and R. Teruel. 1998. Taxonomy of Stenochrus brevipatellatus, n. comb. (Schizomida, Hubbardiidae). Iheringia, Serie Zoologia 85: 47-49.

Armas, L.F. de, and R. Teruel. 2002. Un género nuevo de Hubbardiidae (Arachnida. Schizomida) de las
Antillas Mayores. Revista Ibérica de Aracnología 6: 45-52.

Armas, L.F. de, and R. Teruel. 2009. Nuevas consideraciones sobre algunos géneros de esquizómidos troglomorfos de Cuba (Schizomida: Hubbardiidae). Boletín de la Sociedad Entomológica Aragonesa 45: 447-451.

Armas, L.F. de, and R. Teruel. 2011. On the fossil schizomids (Schizomida: Hubbardiidae) from Dominican Republic amber. Boletín de la Sociedad Entomológica Aragonesa 48: 335-336.

Armas, L.F. de, and C. Víquez. 2009. Primer registro del género Piaroa Villarreal, Giupponi et Tourinho, 2008 (Schizomida: Hubbardiidae) en Centroamérica, con la descripción de una especie nueva de Costa Rica. Boletín Sociedad Entomológica Aragonesa 44: 131-133.

Armas, L.F. de, and C. Víquez. 2010. Nuevos Hubbardiidae (Arachnida: Schizomida) de América Central. Boletín de la Sociedad Entomológica Aragonesa 46: 9-21.

Armas, L.F. de, C. Víquez, and R. Miranda. 2010. Adiciones a la fauna panameña de esquizómidos (Schizomida: Hubbardiidae). Boletín de la Sociedad Entomologica Aragonesa 46: 499-501.

Armas, L.F. de, R. Barba Díaz, and A. Alegre Barroso. 2017. Redescription of the monotypic genus Cubacanthozomus (Schizomida: Hubbardiidae) and conservation status of its type-species. Zootaxa 4323 (4): 534-546.

Baert, L., and V. Mahnert. 2015. The distribution of the non-Araneae and non-Acari arachnids of Galápagos. Belgian Journal of Entomology 28: 1-76.

Baert, L., J.P. Maelfait and K. Desender. 1996. Distribution of the arachnid species of the orders Scorpiones, Solifugae, Amblypygi, Schizomida, Opiliones and Pseudoscorpiones in Galápagos. Bulletin de l'Institut Royal des Sciences Naturelles de Belgique, Entomologie 65: 5-19.

Barranco, P., J.G. Mayoral, and G.A. Garcia. 2014. Primer registro de esquizómidos en la Península Ibérica (Arachnida, Schizomida). Boletín de la Asociación Española de Entomología 38: 295-301.

Beck, B.F., M. Fram, and J.R. Carvajal. 1976. The Aguas Buenas Caves, Puerto Rico: geology, hydrology, and ecology with special reference to the histoplasmosis fungus. National Speleological Society Bulletin 38:1-16.

Beron, P. 2017. Comparative arachnogeographical analysis between the faunas of Central America and the Antilleans (Caribbeans). Historia Naturalis Bulgarica 24: 33-59. 
Bolívar and C. Pieltain. 1944. Exploración biológica de algunas cavernas de Cuba. Ciencia, México 4: 301-304.

Borror, D.J, D.M. DeLong, and C.A Triplehorn. 1981. An introduction to the study of insects. Philadelphia: Saunders College Publishing.

Borror, D.J., C.A Triplehorn, and N.F. Johnson. 1989. An introduction to the study of insects. Fort Worth: Saunders College Publishing.

Brach, V. 1976. Development of the whipscorpion Schizomus floridanus with notes on behavior and laboratory culture. Bulletin of the Southern California Academy of Sciences 74 (3): 97-100.

Brignoli, P.M. 1973. Note sulla morfologia dei genitali degli schizomidi e diagnosi preliminari di due nuove species del Messico (Arachnida, Schizomida). Fragmenta Entomologica 9: 1-9.

Brignoli, P.M. 1974. Un nuovo Schizomida delle Batu Caves in Malesia (Arachnida, Schizomida). Revue Suisse de Zoologie 81 (4): 731-735.

Bücherl, W. 1971. Clase II. Los Arácnidos (Arachnida). In L. Cendrero (editor), Zoología hispanoamericana, Invertebrados: 347-464. D.F., México: Editorial Porrúa, SA.

Cabezas-Cruz, A. et al. 2016. Anaplasma phagocytophilum increases the levels of histone modifying enzymes to inhibit cell apoptosis and facilitate pathogen infection in the tick vector Ixodes scapularis. Epigenetics 11 (4): 303-319.

Camilo, G.R., and J.C. Cokendolpher. 1988. Schizomidae de Puerto Rico. Caribbean Journal of Science 24 (1-2): 52-59.

Cárdenas-Figueroa, M. 1950. Los recursos naturales de Yucatán. IV. Informe hidrobiológico y faunístico de Yucatán. Boletín de la Sociedad Mexicana de Geografía y Estadística 69: 135-159.

Chamberlin, R.V. 1922. Two new American arachnids of the order Pedipalpida. Proceedings of the Biological Society of Washington 35: 11-12.

Chamberlin, R.V., and W. Ivie. 1938. VII. Arachnida of the orders Pedipalpida, Scorpionida and Ricinulida. Carnegie Institution of Washington Publications 491: 101-107.

Christophoryová, J., A. Šestáková, M. Krumpál, and P. Fend’a. 2013. First record of a schizomid, Stenochrus portoricensis (Schizomida: Hubbardiidae), in Slovakia. Arachnologische Mitteilungen 45: 25-29.

Cloudsley-Thompson, J.L. 1949. Notes on Arachnida. II. Schizomida in England. Entomologists' Monthly Magazine 85: 261.

Cloudsley-Thompson, J.L. 1958. Spiders, scorpions, centipedes and mites. The ecology and natural his- tory of woodlice, myriapods and arachnids. New York: Pergamon Press.

Cloudsley-Thompson, J.L. 1968. Spiders, scorpions, centipedes and mites. Oxford: Pergamon Press.

Clouse, R.M. et al. 2017. First global molecular phylogeny and biogeographical analysis of two arachnid orders (Schizomida and Uropygi) supports a tropical Pangean origin and mid-Cretaceous diversification. Journal of Biogeography 44 (11): 2660 2672.

Coddington, J.A., S.F. Larcher, and J.C. Cokendolpher. 1990. The systematic status of Arachnida, exclusive of Acari, in North America north of Mexico. In M. Kosztarab and C.W. Schaefer (editors), Systematics of the North American insects and arachnids: status and needs: 5-20. Blacksburg, VA: Polytechnic Institute and State University.

Cokendolpher, J.C., and J.R. Reddell. 1984a. On the ongoing research (the order Schizomida). American Arachnology 29: 5.

Cokendolpher, J.C., and J.R. Reddell. 1984b. The male of Schizomus sbordonii Brignoli (Schizomida, Schizomidae). Journal of Arachnology 12: 241-243.

Cokendolpher, J.C., and J.R. Reddell. 1992. Revision of the Protoschizomidae (Arachnida: Schizomida) with notes on the phylogeny of the order. Texas Memorial Museum, Speleological Monographs 3: 31-74.

Cokendolpher, J.C., and J.R. Reddell. 2000. New and rare Schizomida (Arachnida: Hubbardiidae) from South America. Amazoniana 16: 187-212.

Cook, O.F. 1899. Hubbardia, a new genus of Pedipalpi. Proceedings of the Entomological Society of Washington 4: 249-261.

Cutler, B., and L. McCutchen. 2006. Heavy metals in cuticular structures of Palpigradi, Ricinulei, and Schizomida (Arachnida). Journal of Arachnology 34 (3): 653-656.

Dabert, M. et al. 2010. Molecular phylogeny of acariform mites (Acari, Arachnida): strong conflict between phylogenetic signal and long-branch attraction artifacts. Molecular Phylogenetics and Evolution 56 (1): 222-241.

Darriba, D., G.L. Taboada, R. Doallo, and D. Posada. 2012. jModelTest 2: more models, new heuristics and parallel computing. Nature Methods 9 (8): 772.

De Bivort B.L., R. Clouse, G. Giribet. 2009. A morphometrics based phylogeny of the temperate Gondwanan mite harvestmen (Opiliones, Cyphophthalmi, Pettalidae). Journal of Zoological Systematics and Evolutionary Research 48: 294-309. 
Delfín-González, H., V.M. Ramírez, P.C. Manrique-S, A. Martin-Park, and C. Arisqueta-Chablé. 2017. Contribution to the knowledge of the arachnids on the Yucatán Peninsula, Mexico (excluding Aranae and Acari). Tropical and Subtropical Agroecosystems 20: 279-288.

Delgado-Santa, L., and L.F. de Armas. 2013. Tres nuevos Hubbardiinae (Schizomida. Hubbardiidae) de Colombia. Revista Ibérica de Aracnología 22: 37-45.

Dumitresco, M. 1977. Autres nouvelles espéces du genre Schizomus des grottes de Cuba. Résultats des Expéditions Biospéologiques Cubano-Roumaines à Cuba 2: 147-158.

Farris J.R. 1970. Methods for computing Wagner trees. Systematic Zoology 19: 83-92.

Fitch W.M. 1971. Toward defining the course of evolution: minimum change for a specific tree topology. Systematic Zoology 20: 406-416.

Gallão, J.E., M.E. Bichuette, and A.P.L. Giupponi. 2015. First record of Stenochrus portoricensis Chamberlin, 1922 (Arachnida: Schizomida: Hubbardiidae) for caves in Brazil: evidence for a troglophile status of an exotic species. Check List 11 (1): 1.

Gertsch, W.J. 1940. Two new American whip-scorpions of the family Schizomidae. American Museum Novitates 1077: 1-4.

Gertsch, W.J. 1979. American spiders. New York: Van Nostrand Reinhold Co.

Giltay, L. 1935. Notes arachnologiques africaines. VII. Description d'un pédipalpe nouveau du Congo beige (Trithyreus ghesquierei, n.sp.). Bulletin du Musée Royal d'Histoire Naturelle de Belgique, Bruxelles 11 (32): 1-8.

Giribet, G., G.D. Edgecombe, W.C. Wheeler, and C. Babbitt. 2002. Phylogeny and systematic position of Opiliones: a combined analysis of chelicerate relationships using morphological and molecular data. Cladistics 18 (1): 5-70.

Giribet, G., and C. Ribera. 2000. A review of arthropod phylogeny: new data based on ribosomal DNA sequences and direct character optimization. Cladistics 16: 204-231.

Giupponi, A.P.L., G.S. Miranda, and O.M. Villarreal. 2016. Rowlandius dumitrescoae species group: new diagnosis, key and description of new cave-dwelling species from Brazil (Schizomida, Hubbardiidae). ZooKeys 2016 (632): 13-34.

Giupponi, A.P.L., et al. 2018. Aracnídeos de Mata Atlântica. In E.M.L.A Monteiro-Filho and C.E Conte (editors), Revisões em Zoologia, Mata Atlântica: 129-235. Paraná, Brasil: Editora UFPR.
Guzmán, A.L.I.A., D.C. Joya, and O.F. Francke. 2015. The first troglomorphic species of the genus Phrynus Lamarck, 1801 (Amblypygi: Phrynidae) from Mexico. 3920 (3): 474-482.

Harvey, M. 1992. The Schizomida (Chelicerata) of Australia. Invertebrate Systematics 6 (1): 77-129.

Harvey, M.S. 2003. Catalogue of the Smaller Arachnid Orders of the World. Collingwood, Victoria, Australia: CSIRO Publishing.

Harvey, M.S. 2006. The schizomid fauna (Arachnida: Schizomida: Hubbardiidae) of the Arabian Peninsula and Somalia. World (2001): 167-177.

Harvey, M. 2013. Schizomids of the world. Version 1.0. Perth: Western Australian Museum. Online resource (http: //museum.wa.gov.au/catalogues-beta/schizomids).

Harvey, M.S., O. Berry, K.L. Edward, and G. Humphreys. 2008. Molecular and morphological systematics of hypogean schizomids (Schizomida: Hubbardiidae) in semiarid Australia. Invertebrate Systematics 22 (2): 167-194.

$\mathrm{He}$, Q., et al. 2013. The venom gland transcriptome of Latrodectus tredecimguttatus revealed by deep sequencing and cDNA library analysis. PLoS One 8 (11): 1-16.

Hilton, W.A. 1933. A new whip-scorpion from Cuba. PanPacific Entomologist 9: 91-92.

Hoffmann, A., J.G. Palacios-Vargas, and J.B. MoralesMalacara. 1986. Manual de biospeleología (con nuevas aportaciones de Morelos y Guerrero, Méx.). D.F., México: Universidad Nacional Autónoma de México.

Huber, B., J. Neuman, S. Rehfeldt, A. Grabolle, and N. Reiser. 2015. Back in Europe: Quamtana spiders (Araneae: Pholcidae) in Germany. Arachnologische Mitteilungen 50: 51-56.

Humphreys, W.F. 1995. Chorion surface features of chelicerate eggs. Records of the Western Australian Museum, Supplement 52: 171-181.

Humphreys, W.F., M. Adams, and M. Vine. 1989. The biology of Schizomus vinei (Chelicerata: Schizomida) in the caves of Cape Range, Western Australia. Journal of Zoology (London) 217: 177-201.

International Commission on Zoological Nomecnlature (ICZN). 2000. International Code of Zoological Nomenclature. 4th ed. London: International Trust for Zoological Nomenclature.

Katoh, S. 2013. MAFFT multiple sequence alignment software version 7: improvements in performance and usability. Molecular Biology and Evolution 30: $772-780$. 
Klompen, H., M. Lekveishvili, and W.C. Black IV. 2007. Phylogeny of parasitiform mites (Acari) based on rRNA. Molecular Phylogenetics and Evolution 43 (3): 936-951.

Korenko, S., M. Harvey, and S. Pekár. 2009. Stenochrus portoricensis new to the Czech Republic (Schizomida, Hubbardiidae). Arachnologische Mitteilungen 38: 1-3.

Krantz, G.W., and D.E. Walter. 2009. Collecting, rearing, and preparing specimens. In G.W. Krantz and D.E. Walter (editors), A manual of acarology: 83-96. Lubbock, TX: Texas Tech University Press.

Krüger, J., and J.A. Dunlop. 2010. Schizomids (Arachnida: Schizomida) from Dominican Republic amber. Alavesia 3: 43-53.

Kury, A.B., A. Chagas, A.P.L. Giupponi, and A. PérezGonzález. 2010. Amblypygi, Opiliones, Schizomida, Scorpiones and Chilopoda, Tocantins, Brazil. Check List 6 (4): 564-571.

Lanfear, R., P.B. Frandsen, A.M. Wright, T. Senfeld, and B. Calcott. 2016. PartitionFinder 2: new methods for selecting partitioned models of evolution for molecular and morphological phylogenetic analyses. Molecular Biology and Evolution 34 (3): 772-773

Lawrence, R.F. 1969. The trichoid structures on the chelicerae of the short-tailed whip-scorpions (Schizomida: Arachnida). Transactions of the Royal Society of South Africa 38: 123-132.

Levi, H.W. 1982. Schizomida. In S.P. Parker (editor), Synopsis and classification of living organisms: 76. New York: McGraw-HilJ Book Co.

Levi, H.W., and L.R. Levi. 1968. Spiders and their kin. New York: Golden Press.

Lewis, P.O. 2001. A likelihood approach to estimating phylogeny from discrete morphological character data. Systematic Biology 50 (6): 913-925.

Ludwig, M. and Alberti, G. 1990. Peculiarities of arachnid midgut glands. Acta Zoologica Fennica 190: 255-259.

Maddison, W.P., and D.R. Maddison. 2018. Mesquite: a modular system for evolutionary analysis. Version 3.4. Online resource (http: //mesquiteproject.org).

Magalhães I.L.F., and A.J. Santos. 2012. Phylogenetic analysis of Micrathena and Chaetacis spiders (Araneae: Araneidae) reveals multiple origins of extreme sexual size dimorphism and long abdominal spines. Zoological Journal of the Linnean Society 166: 14-53.

Martín, J.L., and P. Oromí. 1984. Consideraciones sobre la presencia de Schizomus portoricensis (Chamberlin, 1922) (Arachnida, Schizomida) en cuevas de
Tenerife (Islas Canarias). Boletín de la Sociedad Entomológica de España 8: 265-270.

Martín, J.L., P. Oromi, and J. Barquín. 1985. Estudio ecológico del ecosistema cavernícola de una sima de origen volcánico: La Sima Robada (Tenerife, Islas Canarias). Endins 10-11: 37-46.

Mello-Leitão. 1931. Pedipalpos do Brasil e algumas notas sobre a ordem. Archivos do Museu Nacional 33: 9-72.

Miller, M.A., W. Pfeiffer, and T. Schwartz. 2010. Creating the CIPRES Science Gateway for inference of large phylogenetic trees. 2010 Gateway Computing Environments Workshop (GCE): 1-8.

Millot, J. 1948. Sur trois ordres d'arachnides nouveaux pour Madagascar avec examen de la répartition géographique des Schizopeltides. Mémoires de l'Académie Malgache, Fascicule Hors Série 1948: 153-156.

Millot, J. 1949. Ordre des Uropyges. In P.P. Grassé (editor), Traité de zoologie, anatomie, systématique, biologie, vol. 6: 533-562. Paris: Masson et Cie.

Monjaraz-Ruedas, R. 2012. A new species of the schizomid genus Stenochrus (Schizomida: Hubbardiidae) from Mexico. Zootaxa 68 (3334): 63-68.

Monjaraz-Ruedas, R., and O.F. Francke. 2015. Taxonomic revision of the genus Mayazomus Reddell and Cokendolpher, 1995 (Schizomida: Hubbardiidae), with description of five new species from Chiapas, Mexico. Zootaxa 3915 (4): 451-490.

Monjaraz-Ruedas, R., and O.F. Francke. 2016. Systematics of the genus Mayazomus (Arachnida: Schizomida): the relevance of using continuous characters and pedipalp setae patterns to schizomid phylogenetics. Zoological Journal of the Linnean Society 176: 781-805.

Monjaraz-Ruedas, R., and O.F. Francke. 2017. A new genus of schizomids (Arachnida: Schizomida: Hubbardiidae) from Mexico, with notes on its systematics. Systematics and Biodiversity 2000: 1-15.

Monjaraz-Ruedas, R., and O.F. Francke. 2018. Five new species of Stenochrus (Schizomida: Hubbardiidae) from Oaxaca, Mexico. Zootaxa 4374 (2): 189-214.

Monjaraz-Ruedas, R., O.F. Francke, J.A. Cruz-López, and C.E. Santibáñez-López. 2016. Annuli and setal patterns in the flagellum of female micro-whipscorpions (Arachnida: Schizomida): hypotheses of homology across an order. Zoologischer Anzeiger 263: 118-134.

Monjaraz-Ruedas, R., O.F. Francke, and C.E. Santibáñez-López. 2017. The morphological phylogeny 
of the family Protoschizomidae revisited (Arachnida: Schizomida): setal characters, fossil and paraphyletic genera. Journal of Arachnology 45: 99-111. Montaño-Moreno, H., and O.F. Francke. 2009. A new species of Agastoschizomus (Schizomida: Protoschizomidae) from Guerrero, Mexico. Texas Memorial Museum, Speleological Monographs 5: 33-36.

Moreno-González, J.A., and O.M. Villarreal. 2012. A new genus of Hubbardiidae (Arachnida: Schizomida) from the Colombian Andes, with some taxonomic comments. Zootaxa 3560: 61-78.

Moreno-González, J.A., and O.M. Villarreal. 2017. Two new species of Calima Moreno-González and Villarreal, 2012 (Arachnida: Schizomida: Hubbardiidae) from the Colombian Andes, with a discussion on the male flagellar microsetae of Hubbardiinae. Journal of Natural History 51 (45-46): 2681-2700.

Moreno-González, J.A., L. Delgado-Santa, and L.F. de Armas. 2014. Two new species of Piaroa (Arachnida: Schizomida, Hubbardiidae) from Colombia, with comments on the genus taxonomy and the flagellar setae pattern of Hubbardiinae. Zootaxa 3852 (2): 227-251.

Muchmore, W.B. 1993. List of terrestrial invertebrates of St. John, U.S. Virgin Islands (exclusive of Acarina and Insecta), with some records of freshwater species. Caribbean Journal of Science 29: 30-38.

Muma, M.H. 1967. Scorpions, whip scorpions, and wind scorpions of Florida (Arachnida: Scorpionida, Pedipalpida, and Solpugida). Arthropods of Florida and Neighboring Land Areas 4: 1-28.

Neave, S.A. 2005. Nomenclator zoologicus. A list of the names of genera and subgenera in zoology from the 10th edition of Linnaeus, 1758, to the end of 2004. Vol. 1-10. Woods Hole, MA: UBio. Online resource (http://www.ubio.org/NomenclatorZoologicus/).

Nedvěd, O. et al. 2011. Ecology of Arachnida alien to Europe. BioControl 56 (4): 539-550.

Nicholas, G. 1962. Checklist of troglobitic organisms of Middle America. American Midland Naturalist 68: 165-188.

Oromí, P., and J.L. Martín. 1992. The Canary Islands subterranean fauna: characterization and composition. In A.I. Camacho (editor), The natural history of biospeleology. Museo Nacional de Ciencias Naturales, Monografias 7: 527-567.

Ortuño, V.M., and D.F. Martínez-Pérez. 2011. Diversidad de Artrópodos en España. Memorias de la Real Sociedad Española de Historia Natural 9: 235-284.

Palacios-Vargas, J.G. 1981. Los artrópodos de la gruta de Acuitlapán, Guerrero. Folia Entomológica Mexicana 48: 64-65.
Palacios-Vargas, J.G. 1983. La fauna de la Gruta de Atoyac, Veracruz. Sociedad Mexicana de Exploraciones Subterráneas, Boletín 2: 42-44.

Palacios-Vargas, J.G. 1990. Miembros de la UMAE. Currículum vitae de José G. Palacios-Vargas. Mundos Subterráneos 1: 3-7.

Palacios-Vargas, J.G., and J.R. Reddell. 2013. Actualización del Inventario Cavernícola (Estigobiontes, Estigófilos y Troglobios) de México. Mundos Subterráneos 24: 33-95.

Palacios-Vargas, J.G., C. Juberthie, and J. Reddell. 2015. Encyclopaedia Biospeologica. Mundos Subterráneos IIa (25-26): 101.

Pearse, A.S. 1945. La fauna. Enciclopedia Yucatanense 1: 109-271.

Peck, S.B. 1974. The invertebrate fauna of tropical American caves, part II: Puerto Rico, an ecological and zoogeographic analysis. Biotropica 6: 14-31.

Peck, S.B. 1975. The invertebrate fauna of tropical American caves, Part III: Jamaica, an introduction. International Journal of Speleology 7: 303-326.

Peck, S.B. 1981. Zoogeography of invertebrate cave faunas in southwestern Puerto Rico. Bulletin of the National Speleological Society 43: 70-79.

Peck, S.B. 1990. Eyeless arthropods of the Galapagos Islands, Ecuador: composition and origin of the cryptozoic fauna of a young, tropical, oceanic archipelago. Biotropica 22: 366-381.

Peck, S.B. 1993. A synopsis of the invertebrate cave fauna of Jamaica. Bulletin of the National Speleological Society 54 (2): 37-60.

Peck, S.B., and J. Kukalova-Peck. 1986. Preliminary summary of the subterranean fauna of the Galapagos Islands, Ecuador. Part 1. Introduction and noninsect invertebrates. Proceedings of the 9th Congreso Internacional de Espeleología, Barcelona, España 2: 164-166.

Pepato, A.R., C.E.F. Da Rocha, and J.A. Dunlop. 2010. Phylogenetic position of the acariform mites: sensitivity to homology assessment under total evidence. BMC Evolutionary Biology 10 (1): 1-23.

Pérez-Gelabert, D.E. 2008. Arthropods of Hispaniola (Dominican Republic and Haiti): a checklist and bibliography. Zootaxa 1831: 1-530.

Pérez, Y., and R. Teruel. 2004. La fauna de arácnidos de dos localidades de Cuba oriental (Arachnida: Scorpiones, Amblypygi, Schizomida, Ricinulei). Revista Ibérica de Aracnología 10: 167-178.

Petrunkevitch, A. 1945. Calcitro fisheri, a new fossil arachnid (Arizona). American Journal of Science 243 (6): 320-329. 
Pierce, W.D. 1950. Fossil arthropods from onyx marble. Bulletin of the Southern California Academy of Sciences 49: 101-104.

Pierce, W.D. 1951. Fossil arthropods from onyx-marble. Bulletin of the Southern California Academy of Sciences 50: 34-49.

Reddell, J.R. 1971. A preliminary bibliography of Mexican cave biology with a checklist of published records. Bulletin of the Association for Mexican Cave Studies 3: 1-184.

Reddell, J.R. 1973. Ten years of Mexican cave biology. Newsletter of the Association for Mexican Cave Studies 4: 31-43.

Reddell, J.R. 1977. A preliminary survey of the caves of the Yucatán Peninsula. Bulletin of the Association for Mexican Cave Studies 6: 215-296.

Reddell, J.R. 1981. A review of the cavernicole fauna of Mexico, Guatemala, and Belize. Bulletin of the Texas Memorial Museum 27: 1-327.

Reddell, J.R 1982. A checklist of the cave fauna of México. VII. Northern Mexico. Bulletin of the Association for Mexican Cave Studies 8: 249-283.

Reddell, J.R. 2012. Spiders and related groups. In D.C. Culver and W.B. White (editors), Encyclopedia of caves, 2nd ed.: 786-797. San Diego, CA: Elsevier/ Academic Press.

Reddell, J.R., and J.C. Cokendolpher. 1984. A new species of troglobitic Schizomus (Arachnida: Schizomida) from Ecuador. Bulletin of the British Arachnological Society 6 (4): 172-177.

Reddell, J.R., and J.C. Cokendolpher. 1986. New species and records of Schizomus (Arachnida. Schizomida) from Mexico. Texas Memorial Museum, Speleological Monographs 1: 31-38.

Reddell, J.R., and J.C. Cokendolpher. 1991. Redescription of Schizomus crassicaudatus (Pickard-Cambridge) and diagnoses of Hubbardia Cook, Stenochrus Chamberlin, and Sotanostenochrus new genus, with description of a new species of Hubbardia from California (Arachnida: Schizomida: Hubbardiidae). Pearce Sellards Series 47: 1-24.

Reddell, J.R., and J.C. Cokendolpher. 1995. Catalogue, bibliography, and generic revision of the order Schizomida (Arachnida). Texas Memorial Museum, Speleological Monographs 4 (4): 1-170.

Reddell, J.R., and W.R. Elliott. 1973. A checklist of the cave fauna of México. V. Additional records from the Sierra de Guatemala, Tamaulipas. Bulletin of the Association for Mexican Cave Studies 5: 181-190.

Reddell, J.R., and R.W. Mitchell. 1971a. A checklist of the cave fauna of México. I. Sierra de El Abra, Tam- aulipas and San Luis Potosí. Bulletin of the Association for Mexican Cave Studies 4: 137-180.

Reddell, J.R., and R.W. Mitchell. 1971b. A checklist of the cave fauna of México. II. Sierra de Guatemala, Tamaulipas. Bulletin of the Association for Mexican Cave Studies 4: 181-215.

Regier C. et al. 2010. Arthropod relationships revealed by phylogenomic analysis of nuclear protein-coding sequences. Nature 463: 1079-1084.

Rémy, P.A. 1961. Sur l'écologie des Schizomides (Arachn. Uropyges) de mes récoltes, avec description de trois Schizomus nouveaux, capturés par J. van der Drift au Surinam. Bulletin du Muséum National d'Histoire Naturelle, 2e série 33: 406414.

Ribera, C. 1986. Els aracnids (escorpins, pseudoscorpins, araneids, els grups exotics: uropigis, esquizomids, amblipigis, ricinulis). In C. Ribera (editor), Historia natural dels paisos catalans, 9. Artropodes 1: 85-191. Barcelona: Enciclopedia Catalana.

Rowland, J.M. 1971a. New species of schizomids (Arachnida, Schizomida) from Mexican caves. Bulletin of the Association for Mexican Cave Studies 4: 117-126.

Rowland, J.M. 1971b. A new Trithyreus from a desert oasis in southern California (Arachnida: Schizomida: Schizomidae). Pan-Pacific Entomologist 47: 304-309.

Rowland, J.M. 1973a. A new genus and several new species of Mexican schizomids (Schizomida: Arachnida). Occasional Papers of the Museum, Texas Tech University 11: 1-23.

Rowland, J.M. 1973b. Revision of the Schizomida (Arachnida). Journal of the New York Entomological Society 80 (4): 195-204.

Rowland, J.M. 1973c. Three new Schizomida of the genus Schizomus from Mexican caves (Arachnida). Bulletin of the Association for Mexican Cave Studies 5: 135-140.

Rowland, J.M. 1975a. A partial revision of Schizomida (Arachnida), with descriptions of new species, genus, and family. Occasional Papers of the Museum, Texas Tech University 31: 1-21.

Rowland, J.M. 1975b. Classification, phylogeny and zoogeography of the American arachnids of the order Schizomida. Ph.D. dissertation, Texas Tech University, Lubbock, TX.

Rowland, J.M., and J.R. Reddell. 1976. Annotated checklist of the arachnid fauna of Texas (excluding Acarida and Araneida). Occasional Papers of the Museum, Texas Tech University 38: 1-25. 
Rowland, J.M., and J.R. Reddell. 1977. A review of the cavernicole Schizomida (Arachnida) of Mexico, Guatemala and Belize. Bulletin of the Association for Mexican Cave Studies 6: 79-102.

Rowland, J.M., and J.R. Reddell. 1979a. The order Schizomida (Arachnida) in the New World. I. Protoschizomidae and dumitrescoae group (Schizomidae: Schizomus). Journal of Arachnology 6: 161-196.

Rowland, J.M., and J.R. Reddell. 1979b. The order Schizomida (Arachnida) in the New World. II. simonis and brasiliensis groups (Schizomidae: Schizomus). Journal of Arachnology 7: 89-119.

Rowland, J.M., and J.R. Reddell. 1980. The order Schizomida (Arachnida) in the New World. III. mexicanus and pecki groups (Schizomidae, Schizomus). Journal of Arachnology 8: 1-34.

Rowland, J.M., and J.R. Reddell. 1981. The order Schizomida (Arachnida) in the New World. IV. goodnightorum and briggsi groups and unplaced species (Schizomidae: Schizomus). Journal of Arachnology 9: 19-46.

Ruíz C.E., and J.M. Coronado. 2002. Artrópodos terrestres de los estados de Tamaulipas y Nuevo León, México. Primera. E. Ruíz C. and J. M. Coronado B. (editors). Mexico: Publicaciones Científicas CIDAFF-UAT.

Ruiz, G.R.S., and R.M. Valente. 2017. The first schizomid from a dry forest in South America (Arachnida: Schizomida). Zootaxa 4311 (1): 81-95.

Santos, A.J., and R. Pinto-da-Rocha. 2009. A new micro-whip scorpion species from Brazilian Amazonia (Arachnida, Schizomida, Hubbardiidae), with the description of a new synapomorphy for Uropygi. Journal of Arachnology 37 (1): 39-44.

Santos, A.J., C.D. Sidclay, D.A. Brescovit, and P.P.P. Santos. 2008. The arachnid order Schizomida in the Brazilian Atlantic Forest: a new species of Rowlandius and new records of Stenochrus portoricensis (Schizomida: Hubbardiidae). Zootaxa 1850: 53-60.

Santos, A.J., R.L. Ferreira, and B.A. Buzatto. 2013. Two New cave-dwelling species of the short-tailed whipscorpion genus Rowlandius (Arachnida: Schizomida: Hubbardiidae) from northeastern Brazil, with comments on male dimorphism. PLoS ONE 8 (5): $1-12$.

Savory, T.H. 1964. Arachnida. New York: Academic Press.

Savory, T.H. 1977. Arachnida. 2nd ed. New York: Academic Press.

Sbordoni, V., R. Argano, and A. Zullini. 1974. Biological investigations on the caves of Chiapas (Mexico) and adjacent countries: Introduction. Accademia Nazionale dei Lincei, Problemi Attuali di Scienza e di Cultura, Quaderno 171 (2): 5-45.

Šestáková, A., M. Suvák, K. Krajčovičová, A. Kaňuchová, and J. Christophoryová. 2017. Arachnids from the greenhouses of the Botanical Garden of the PJ Šafárik University in Košice, Slovakia (Arachnida: Araneae, Opiliones, Palpigradi, Pseudoscorpiones). Arachnologische Mitteilungen 53: 19-28.

Shimojana, M. 1972. Distribution of Arachnida in the Ryukyu Islands. Iden, Tokyo 26 (5): 100-106.

Shultz, J.W. 2007. A phylogenetic analysis of the arachnid orders based on morphological characters. Zoological Journal of the Linnean Society 150 (2): 221-265.

Sket, B., and T.M. Iliffe. 1980. Cave fauna of Bermuda. Intemationale Revue der Gesamten Hydrobiologie 65: 871-882.

Souza, A.M. de, and A.F.A. Lira. 2015. First record of Stenochrus portoricensis Chamberlin, 1922 (Arachnida: Schizomida: Hubbardiidae) for the Pernambuco state, Brazil. Brazilian Journal of Biology 75 (3): 766-767.

Spanga, J.C., and R.G. Gillespie. 2006. Unusually long Hyptiotes (Araneae, Uloboridae) sequence for small subunit (18S) ribosomal RNA supports secondary structure model utility in spiders. Journal of Arachnology 34 (3): 557-565.

Stamatakis, A. 2014. RAxML Version 8: A tool for phylogenetic analysis and post-analysis of large phylogenies. Bioinformatics 30 (9): 1312-1313.

Steele, C.W., and J.H. Smith. 2012. Sistema Huautla, Mexico. In W.B White, and D.C. Culver (editors), Encyclopedia of caves. 2nd ed.: 712-718. Tokyo: Academic Press.

Swofford D.L, and W.P. Maddison. 1987. Reconstructing ancestral character states under Wagner parsimony. Mathematical Biosciences 87: 199-229.

Takashima, H. 1941. Supplementary notes on our knowledge of Scorpionida and Pedipalpi. Acta Arachnologica 6: 87-98.

Takashima, H. 1947. An introduction to the Pedipalpi of the Oriental region. Acta Arachnologica 10: 32-50.

Takashima, H. 1948. Notes on pedipalps of Japan and adjacent territories. Acta Arachnologica 10: 93-108.

Takashima, H. 1951. Notes on schizomids (Yaitomushinôto). Acta Arachnologica 12: 102. [in Japanese]

Talanda, J. 2016. Ekologia Miejska Z Punktu Widzenia Biologa-Wybrane Aspekty I Perspektywy Badań. Kosmos Preblemy Neuk Biologicznych 2 (311): 277-283. 
Teruel, R. 2003. Adiciones a la fauna cubana de esquizómidos, con la descripción de un nuevo género y nueve especies nuevas de Hubbardiidae (Arachnida: Schizomida). Revista Ibérica de Aracnología 7: 39-69.

Teruel, R. 2004. Nuevas adiciones a la fauna de esquizómidos de Cuba oriental, con la descripción de cuatro nuevas especies (Schizomida: Hubbardiidae). Revista Ibérica de Aracnología 9: 31-42.

Teruel, R. 2007. Esquizómidos troglomorfos de Cuba, con las descripciones de dos géneros y una especie nuevos (Schizomida: Hubbardiidae: Hubbardiinae). Boletín de la Sociedad Entomológica Aragonesa 40: 39-53.

Teruel, R. 2012. Estatus de conservación del orden Schizomida (Arthropoda: Arachnida) en Cuba Oriental. Revista Ibérica de Aracnología 21: 38-40.

Teruel, R. 2017a. A new genus of micro-whipscorpions (Schizomida: Hubbardiidae) from western Cuba. Arthropoda Selecta 26 (1): 41-47.

Teruel, R. 2017b. Taxonomic revision of the genus Cubazomus Reddell \& Cokendolphe, 1995, with description of a new species from Cuba (Schizomida: Hubbardiidae). Revista Ibérica de Aracnología 30: 71-81.

Teruel, R., and L.F. de Armas. 2002. Un género nuevo de Hubbardiidae (Arachnida: Schizomida) del occidente de Cuba. Revista Ibérica de Aracnología 6: 91-94.

Teruel, R., and L.F. de Armas. 2005. Novedades aracnólogicas de República Dominicana (Arachnida: Amblypygi, Schizomida, Solpugida, Uropygi). Boletin de la Sociedad Entomológica Aragonesa 37: $129-133$.

Teruel, R., and L.M. Infante. 2009. La aracnofauna del Jardín Botánico "Cupaynicú", Granma, Cuba (Arachnida: Scorpiones, Amblypygi, Schizomida, Ricinulei). Boletín de la Sociedad Entomológica Aragonesa 44: 383-391.

Teruel, R., L.F. de Armas, and T.M. Rodríguez. 2012. Adiciones a los esquizómidos de Cuba Central, con la descripción de cuatro nuevos Rowlandius Reddell \& Cokendolpher 1995 (Schizomida: Hubbardiidae). Revista Ibérica de Aracnología 21: 97-112.

Tourinho, A.L.M., and A.B. Kury. 1999. The southernmost record of Schizomida in South America, first records of Schizomida for Rio de Janeiro and of Stenochrus Chamberlin, 1922 for Brazil (Arachnida, Schizomida, Hubbardiidae). Boletim do Museu Nacional, Rio de Janeiro (Nova Série) Zoologia 405: 1-6.

Vandel, A. 1964. Biospéologie. La biologie des animaux cavemicoles. Paris: Gauthier-Villars.
Vandel, A. 1965. Biospeleology. The biology of cavernicolous animals. New York: Pergamon Press.

Vázquez-Rojas, I. 1995. Los Arácnidos de México parte I: Ricinulei, Amblypygi, Solifugae, Palpigradi, Schizomida, Uropygi. Dugesiana 2: 15-37.

Vázquez-Rojas, I. 1996. Schizomida. In J.E. LlorenteBousquets, A.N. García-Aldrete, and E. González Soriano (editors), Biodiversidad, taxonomía y biogeografía de artrópodos de México: Hacia una síntesis de su conocimiento: 63-66. D.F.: Mexico: Universidad Nacional Autonóma de México.

Villarreal, O.M., and L.F. García. 2012. A new species of Piaroa Villarreal, Giupponi and Tourinho, 2008 (Schizomida: Hubbardiidae) from Colombia. Turkish Journal of Zoology 36 (2): 185-189.

Villarreal, O.M., A.P. Giupponi, and A.L. Tourinho. 2008. New Venezuelan genus of Hubbardiidae (Arachnida: Schizomida). Zootaxa 68 (1860): 60-68.

Villarreal, O.M., L.F. de Armas, and L.F. García. 2014. A new species of Piaroa (Schizomida: Hubbardiidae) from Venezuela, with taxonomic notes on the genus. Zootaxa 3765 (4): 371-381.

Villarreal, O.M., G.S. Miranda, and A.P.L. Giupponi. 2016. New proposal of setal homology in Schizomida and revision of Surazomus (Hubbardiidae) from Ecuador. PLoS ONE 11 (2): 1-29.

Vine, B., B. Knott, and W.F. Humphreys. 1988. Observations on the environment and biology of Schizomus vinei (Chelicerata: Scruzomida) from Cape Range, Western Australia. Records of the Western Australian Museum 14: 21-34.

Vomero, A. 1974. Troglobacanius n.gen. with four new species, a line of cave-adapted Mexican Histeridae (Coleoptera). Accademia Nazionale dei Lincei, Problemi Attuali di Scienza e di Cultura, Quaderno 171 (2): 325-361.

Wallberg, A., M. Thollesson, J.S. Farris, and U. Jondelius. 2004. The phylogenetic position of the comb jellies (Ctenophora) and the importance of taxonomic sampling. Cladistics 20 (6): 558-578.

Werner, F. 1935. Klasse: Arachnoidea, Spinnentiere. Pedipalpen. In H.G. Bronn (editor), Klassen und Ordnungen des Tierreichs, vol. 5: 317-490. Leipzig: Akademische Verlagsgesellschaft.

Wheeler, W.C., et al. 2017. The spider tree of life: phylogeny of Araneae based on target-gene analyses from an extensive taxon sampling. Cladistics 33: 574-616.

Zacharda, M., and W.R. Elliott. 1985. Robustocheles infernalis sp. n. (Acarina: Actinedida: Rhagidiidae) 
from Cueva del Diablo, Veracruz, México. Acta Universitatis Carolinae, Biologica 30 (9): 477-481.

Zawierucha, K., P. Szymkowiak, M. Dabert, and M.S. Harvey. 2013. First record of the schizomid Stenochrus portoricensis (Schizomida: Hubbardiidae) in Poland, with DNA barcode data. Turkish Journal of Zoology 37 (3): 357-361.

Zonstein, S.L. 2004. The spider chelicerae: some problems of origin and evolution. In D.V. Logunov and D. Penney (editors), European Arachnology 2003 (special issue 1): 349-366. Arthoropoda Selecta.

\section{APPENDIX 1}

\section{Morphological Characters Used in Phylogenetic Analysis of the Short-TAILED Whipscorpion Genus Stenochrus Chamberlin, 1922, and Related Genera (Schizomida: HUBBARDIIDAE)}

Characters optimized with ACCTRAN, except where indicated otherwise.

\section{Chelicerae}

0 . Fixed finger, prolateral surface, G3 setae position: seta G3-4 posterior (0); setae G3-2 and G3-4 posterior (1); seta G3-3 anterior (2). [DELTRAN]

1. Fixed finger, prolateral surface, number of G5 setae: $\leq 8(1) ; \geq 9$ (2).

2. Movable finger, mesal surface, margin: smooth (0); lamella (1); dentate (2). [DELTRAN]

\section{Prosomal propeltidium}

3. Anterior process setation: $1+1(0) ; 2+1(1)$.

4. Dorsal pairs of setae, number: $2(0) ; 3(1) ; 4$ (2).

\section{Prosomal metapeltidium}

5. Metapeltidium: divided (0); entire (1).

\section{Opisthosoma}

6. Segments X-XII (ð): not elongate (0); elongate (1).

7. Segment XII, posterodorsal process (ð): absent (0); present (1).

8. Tergite II, number of setae: $2(0) ;>2(1)$.

\section{Pedipalps}

9. Pedipalps, development ( $\widehat{0})$ : homeomorphic (0); elongated (1); robust (2).

\section{Pedipalp trochanter}

10. Apical process: acute (0); acuminate (1); obtuse (2); bump (3); fan-shaped (4); digitiform (5); rounded (6).

\section{Pedipalp femur}

11. Retrolateral surface, seta $F e_{1}$, type: acuminate (0); spiniform (1); macrosetae (2).

12. Retrolateral surface, seta $\mathrm{Fe}_{5}$, type: acuminate (0); spiniform (1); spiniform setiferous tubercle (2); macrosetae (3).

13. Retrolateral surface, seta $F v_{1}$, type: acuminate (0); spiniform (1); spiniform setiferous tubercle (2); macrosetae (3).

14. Retrolateral surface, seta $F v_{2}$, type: acuminate (0); spiniform (1); spiniform setiferous tubercle (2); macrosetae (3).

15. Retrolateral surface, spiniform setiferous tubercles, position: $F v_{1}$ and $F v_{2}$ distal (0); $F v_{1}$ ventral, $F v_{2}$ distal (1); $F v_{1}$ and $F v_{2}$ ventral (2). [DELTRAN]

16. Prolateral surface, anterior margin, apophysis: absent (0); present (1).

17. Prolateral surface, ventral row of setae $\left(F m v_{1-4}\right)$, number: $3(0) ; 4(1)$.

\section{Pedipalp patella}

18. Curvature: slight (0); marked (1); none (2).

19. Retrolateral row of setae $(\mathrm{Pe})$, count: $3(0) ; 4$ (1); 5 (2); 2 (3).

20. Retrolateral row of setae $(P e)$, type: acuminate (0); feathered (1); spiniform (2); macrosetae (3).

21. Prolateral row of setae (Pm), count: $3(0) ; 4$ (1); 5 (2); 6 (3).

22. Prolateral row of setae $(P m)$, type: acuminate (0); feathered (1); spiniform (2); macrosetae (3).

\section{Pedipalp tibia}

23. Spurs: absent (0); ventral (1); proventral (2).

24. Retrolateral row of setae (Ter), count: $3(0) ; 4$ (1); 5 (2); 6 (3). 
25. Retrolateral row of setae (Ter), type: (0) acuminate (0); feathered (1); spiniform (2); macrosetae (3).

26. Medial row of setae (Tmr), count: $3(0) ; 4(1)$; $5(2) ; 6(3)$.

27. Medial row of setae (Tmr), type: acuminate (0); feathered (1); spiniform (2); macrosetae (3).

28. Prolateral row of setae (Tir), count: $3(0) ; 4$ (1); 5 (2); 6 (3).

29. Prolateral row of setae (Tir), type: acuminate (0); feathered (1); spiniform (2); macrosetae (3).

\section{Male flagellum}

30. Shape, dorsal view: lanceolate $(0)$; cordate (1); spatulate (2); subrhomboidal (3); shovel shaped (4); elliptical (5); trilobed (6); bulbous or clavate (7); spear shaped (8); deltoid (9). [DELTRAN]

31. Shape, lateral view: slender (flat) (0); elliptical (1); bulbous (2).

32. Dorsal depressions: absent (0); pair of pits (1); single depression (2); pair of depressions (3); depression and pits (4).

33. Dorsal depressions, position: medial (0); submedial (1); anterior (2); posterior (3).

34. Dorsal projections: flat (0); pair of projections (1); single projection (2).

35. Dorsal projections, position: medial (0); submedial (1). [DELTRAN]

36. Seta $D m_{1}$, position with respect to anterior margin: posterior (0); aligned with margin (1).

37. Seta $\mathrm{Dm}_{4}$, position with respect to seta $\mathrm{Dl}_{3}$ : anterior to (0); aligned with (1).

38. Setae $D l_{1}$, position with respect to setae $V l_{1}$ : aligned with (0); posterior to (1); anterior to (2).

39. Setae $D l_{3}$, position with respect to setae $V l_{2}$ : aligned with (0); posterior to (1); anterior to (2).

40. Seta $V m_{1}$, position with respect to setae $V m_{2}$ : aligned with (0); posterior to (1); anterior to (2).

\section{Female flagellum}

41. Flagellomeres, count: 3 (0); 4 (1).

42. Setae $D l_{1}$, position with respect to setae $V l_{1}$ : aligned with (0); posterior to (1); anterior to (2).

43. Setae $D l_{3}$, position with respect to setae $V l_{2}$ : aligned with (0); posterior to (1); anterior to (2).

\section{Spermathecae}

44. Lobes, number of pairs: $1(0) ; 2(1) ; 3$ or more (2).

45. Median lobes, shape: linear (0); arch shaped (1); inverse J-shaped (2).

46. Median lobes, ornamentation: sclerotized (0); bulbs (1); smooth (2).

47. Median lobes, sclerotization: apically (0); half of lobe (1); entire lobe (3).

48. Median lobes, bulbs size: large (0); small (1).

49. Median lobes, apex orientation: ental (0); ectal (1); vertical (2).

50. Median lobes, base position relative to bases of lateral lobes: aligned with (0); anterior to (1); posterior to (2).

51. Lateral lobes, shape: linear (0); arch shaped (1).

52. Lateral lobes, ornamentation: sclerotized (0); smooth (1).

53. Lateral lobes, apex orientation: ental (0); ectal (1); vertical (2).

54. Lateral lobes, length compared with median lobes: equal (0); $3 / 4$ (1); 1/2 (2); $1 / 4$ (3).

55 . Lobes, relative widths: equal $(0)$; lateral lobes wider than median lobes (1); median lobes wider than lateral lobes (2).

56 . Lobes, symmetry: symmetric (0); asymmetric (1).

57. Chitinized arch, shape: arrow shaped (0); mug shaped (1); V-shaped (2); hastate (3); bowl shaped (4); inverse arc (5); obtuse triangle (6); U-shaped (7).

58. Chitinized arch, anterior branch: present (0); absent (1).

59. Chitinized arch, lateral tip shape: pointed (0); lobed (1); widened (2).

60. Gonopod: absent (0); present (1) 


\section{APPENDIX 2}

Voucher Numbers for Tissue Samples and GenBank Accession Codes for DNA Sequences from the Internal Transcribed Spacer (ITS), 28S rDNA (28S), Cytochrome C Oxidase Subunit I (COI) and $12 S$ rDNA (12S) Used in Phylogenetic Analysis of the Short-Tailed Whipscorpion Genus Stenochrus Chamberlin, 1922, and Related Genera (Schizomida: Hubbardiidae)

Samples deposited in the Ambrose Monell Cryocollection (AMCC) at the American Museum of Natural History, New York, and the Coleccion Nacional de Arácnidos (CNAN) at Instituto de Biología, UNAM, Mexico.

\begin{tabular}{|c|c|c|c|c|c|c|}
\hline Species & Voucher & Country & ITS & $28 S$ & COI & $12 S$ \\
\hline Troglostenochrus valdezi & CNAN Sz206 & Mexico & MK849620 & - & MK801831 & - \\
\hline Baalrog firstmani & AMCC [LP 14531] & Mexico & MK849621 & MK849690 & MK801832 & MK849656 \\
\hline Baalrog magico & AMCC [LP 14516] & Mexico & MK849622 & MK849691 & MK801833 & MK849657 \\
\hline Baalrog sbordonii & AMCC [LP 3757] & Mexico & MK849623 & MK849692 & MK801834 & MK849658 \\
\hline Baalrog yacato & AMCC [LP 3756] & Mexico & MK849624 & MK849693 & MK801835 & MK849659 \\
\hline Nahual bokmai & AMCC [LP 14519] & Mexico & MK849625 & MK849694 & MK801836 & MK849660 \\
\hline Nahual caballero & AMCC [LP 14607] & Mexico & MK849626 & MK849695 & MK801837 & MK849661 \\
\hline Nahual lanceolatus & AMCC [LP 14507] & Mexico & MK849627 & MK849696 & MK801838 & MK849662 \\
\hline Nahual pallidus & AMCC [LP 14524] & Mexico & MK849628 & MK849697 & MK801839 & MK849663 \\
\hline Ambulantactus aquismon & AMCC [LP 14539] & Mexico & MK849629 & MK849698 & MK801840 & MK849664 \\
\hline Ambulantactus montielae & AMCC [LP 14543] & Mexico & MK849630 & MK849699 & MK801841 & MK849665 \\
\hline Harveyus aff. mexicanus & AMCC [LP 14583] & Mexico & MK849631 & MK849700 & MK801842 & MK849666 \\
\hline Harveyus contrerasi & AMCC [LP 14493] & Mexico & MK849632 & MK849701 & MK801843 & MK849667 \\
\hline Harveyus mexicanus & AMCC [LP 14576] & Mexico & MK849633 & MK849702 & MK801844 & MK849668 \\
\hline Schizophyxia lukensi & AMCC [LP 14515] & Mexico & MK849634 & MK849703 & MK801845 & MK849669 \\
\hline $\begin{array}{l}\text { Heteroschizomus } \\
\text { goodnightorum }\end{array}$ & AMCC [LP 14522] & Mexico & MK849635 & MK849704 & MK801846 & MK849670 \\
\hline Heteroschizomus kekchi & AMCC [LP 14559] & Guatemala & MK849636 & MK849705 & MK801847 & MK849671 \\
\hline Heteroschizomus orthoplax & AMCC [LP 14527] & Mexico & MK849637 & MK849706 & MK801848 & MK849672 \\
\hline Heteroschizomus silvino & AMCC [LP 14556] & Guatemala & MK849638 & MK849707 & MK801849 & MK849673 \\
\hline Hubbardia pentapeltis & AMCC [LP 14525] & U.S.A. & MK849639 & MK849708 & MK801850 & MK849674 \\
\hline Mayazomus hoffmannae & AMCC [LP 14643] & Mexico & MK849640 & MK849709 & MK801851 & MK849675 \\
\hline Mayazomus infernalis & AMCC [LP 14644] & Mexico & - & MK849710 & MK801852 & - \\
\hline Olmecazomus cruzlopezi & AMCC [LP 14509] & Mexico & MK849641 & MK849711 & MK801853 & MK849676 \\
\hline Olmecazomus santibanezi & AMCC [LP 14580] & Mexico & MK849642 & MK849712 & MK801854 & MK849677 \\
\hline Sotanostenochrus cookei & AMCC [LP 14545] & Mexico & MK849643 & MK849713 & MK801855 & MK849678 \\
\hline Sotanostenochrus cookei & AMCC [LP 3759] & Mexico & MK849644 & MK849714 & MK801856 & MK849679 \\
\hline Sotanostenochrus mitchelli & AMCC [LP 14503] & Mexico & MK849645 & MK849715 & MK801857 & MK849680 \\
\hline Pacal moisii & AMCC [LP 14502] & Mexico & MK849646 & MK849716 & MK801858 & MK849681 \\
\hline Pacal sp. & AMCC [LP 14508] & Mexico & MK849647 & MK849717 & MK801859 & MK849682 \\
\hline
\end{tabular}




\begin{tabular}{|c|c|c|c|c|c|c|}
\hline Species & Voucher & Country & ITS & $28 S$ & COI & $12 S$ \\
\hline Pacal tepezcuintle & AMCC [LP 14535] & Mexico & MK849648 & MK849718 & MK801860 & MK849683 \\
\hline Pacal trilobatus & AMCC [LP 14652] & Mexico & MK849649 & MK849719 & MK801861 & MK849684 \\
\hline Stenochrus alcalai & AMCC [LP 14655] & Mexico & MK849650 & MK849720 & MK801862 & MK849685 \\
\hline $\begin{array}{l}\text { Stenochrus cf. } \\
\text { guatemalensis }\end{array}$ & AMCC [LP 14562] & Guatemala & MK849651 & MK849721 & MK801863 & MK849686 \\
\hline Stenochrus chimalapas & AMCC [LP 14533] & Mexico & MK849652 & MK849722 & MK801864 & MK849687 \\
\hline Stenochrus gruta & AMCC [LP 14492] & Mexico & MK849653 & MK849723 & MK801865 & - \\
\hline Stenochrus pecki & AMCC [LP 14577] & Mexico & MK849654 & MK849724 & MK801866 & MK849688 \\
\hline Stenochrus portoricensis & AMCC [LP 10149] & Puerto Rico & MK849655 & MK849725 & MK801867 & MK849689 \\
\hline
\end{tabular}





\title{
SCientific Publications of the American Museum of Natural History
}

AMERICAN MUSEUM NOVITATES

BULletin of the American Museum of Natural History

Anthropological Papers of the American Museum of natural History

\author{
Publications Committee \\ ROBERT S. VOSS, CHAIR \\ BOARD OF EDITORS \\ Jin MENG, PALEONTOLOGY \\ LORENZO PRENDINI, INVERTEBRATE ZOOLOGY \\ ROBERT S. VOSS, VerTEBRATE ZOOLOGY \\ Peter M. Whiteley, Anthropology \\ MANAGING EDITOR \\ MARY KNIGHT
}

Submission procedures can be found at http://research.amnh.org/scipubs

All issues of Novitates and Bulletin are available on the web (http://digitallibrary.amnh. org/dspace). Order printed copies on the web from:

http://shop.amnh.org/a701/shop-by-category/books/scientific-publications.html

or via standard mail from:

American Museum of Natural History-Scientific Publications

Central Park West at 79th Street

New York, NY 10024

(2) This paper meets the requirements of ANSI/NISO Z39.48-1992 (permanence of paper).

ON the cover: Stenochrus portoricensis Chamberlin, 1922, $q$ FROM OCOSINGO, CHIAPAS, MEXICO. 